\title{
UNDERSEGELSE AF DE NATIONALE TESTS MÅLEEGENSKABER
}

JEPPE BUNDSGAARD OG SVEND KREINER

\section{REVIDERET \\ 2. UDGAVE}

$\begin{array}{llll}13 & 14 & 15 & 16\end{array}$ $\begin{array}{lll}18 & 19 & 20 \\ 0 & 21 & 22\end{array}$

$$
\begin{aligned}
& \text { Whif } \\
& \text { U. ARHUS } \\
& \text { DPU }
\end{aligned}
$$




\title{
Undersøgelse af De Nationale Tests måleegenskaber
}

2. udgave

\author{
Jeppe Bundsgaard og Svend Kreiner
}


Aarhus Universitet, Danmarks institut for Pædagogik og Uddannelse

København

Fagfællebedømt af Tine Nielsen og Rolf V Olsen.

ISBN: Elektronisk udgave:

Produceret med R bookdown.

2. udgave Version: 25. april 2019

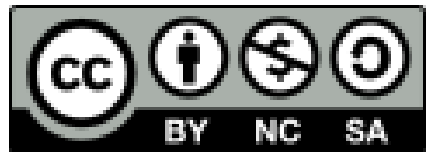

Udgivet under Creative Commons Attribution-NonCommercial-ShareAlike 4.0 International License (C) 2019 Jeppe Bundsgaard og Svend Kreiner 
1 Introduktion $\quad 5$

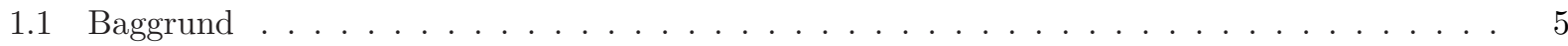

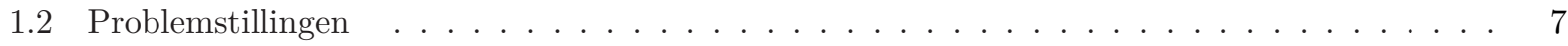

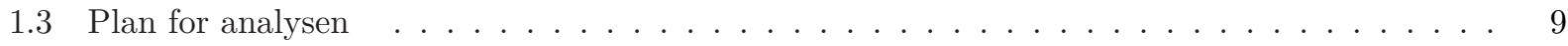

1.4 Tilføjelse til 2 udgave $\ldots \ldots \ldots \ldots \ldots \ldots \ldots \ldots \ldots$

2 Forfatterne, læsevejledning og resultater $\quad 11$

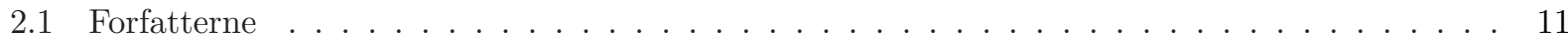

2.2 Rapportens opbygning $\ldots \ldots \ldots \ldots \ldots \ldots \ldots \ldots \ldots \ldots \ldots$

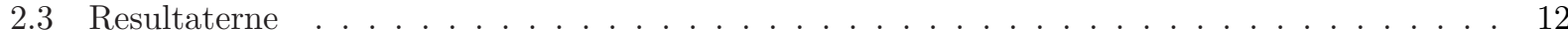

3 De nationale test, måleegenskaber og Rasch-modellen $\quad 15$

3.1 De nationale test . . . . . . . . . . . . . . . . . . . . . . . . 15

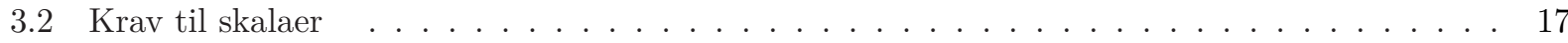

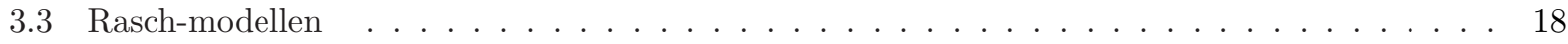

3.4 Adaptive test . . . . . . . . . . . . . . . . . . . . . . . 20

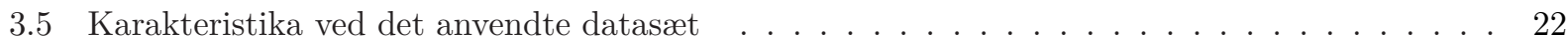

4 Item-analyser af data fra $2017 \quad 25$

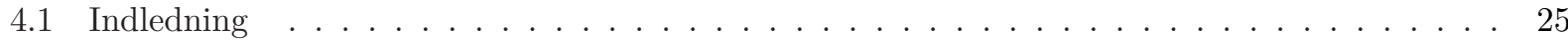

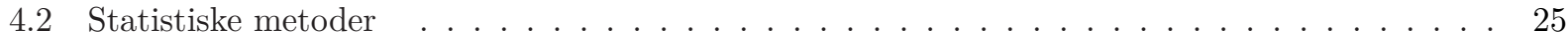

4.3 Sammenligning af sværhedsgrader og elevdygtigheder i 2017-analysen og nationale tests

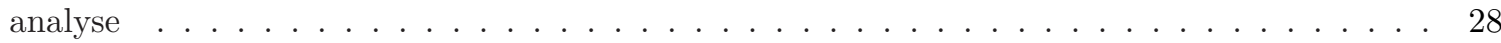

4.4 Fordeling af elevdygtighed $\ldots \ldots \ldots \ldots \ldots \ldots \ldots \ldots \ldots \ldots$

4.5 Estimater på dygtigheder i 2017-analysen og i DNT's analyse . . . . . . . . . . . . . . . 36

4.6 Standard Error of Measurement $(\mathrm{SEM}) \ldots \ldots \ldots \ldots \ldots$

4.7 Er der opgaver med passende sværhedsgrader til eleverne? . . . . . . . . . . . . . . . . 44

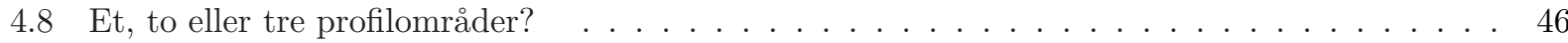

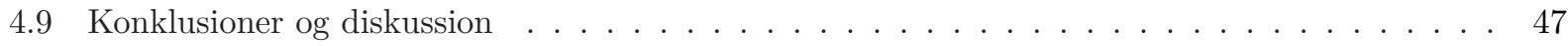


5 Analyser af enkeltstående testforløb 49

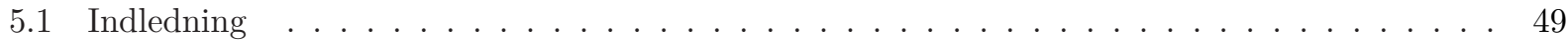

5.2 Metoder til at teste om enkelte testforløb kan beskrives ved hjælp af Rasch-modellen _ . . . 49

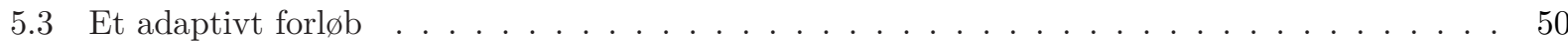

5.4 Først flere forkerte svar, derefter mange rigtige . . . . . . . . . . . . . . . . . . . 54

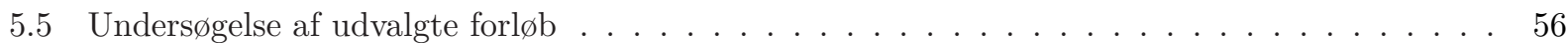

5.6 Afsluttende kommentarer til analyserne . . . . . . . . . . . . . . . . . . . . . 69

6 Konklusioner og anbefalinger $\quad 71$

6.1 Usikkerheden på resultaterne . . . . . . . . . . . . . . . . . . . . . . . . . 74

6.2 Konsekvenser for forskning, kvalitetssikring og beslutninger om indsatser . . . . . . . . . . 74

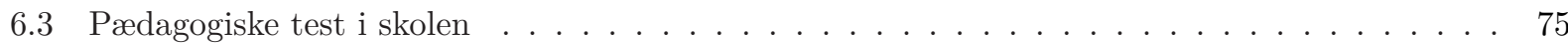

$\begin{array}{lc}\text { Litteratur } & 77\end{array}$

$\begin{array}{lc}\text { Litteratur } & 77\end{array}$

$\begin{array}{lr}\text { Bilag } & 79\end{array}$

$\begin{array}{lr}\text { A Testforløbstabeller } & 81\end{array}$

B Analyse af person-fit baseret på 2017-sværhedsgrader $\quad 89$

B.1 Indledning . . . . . . . . . . . . . . . . . . . . . . . . . . . 89

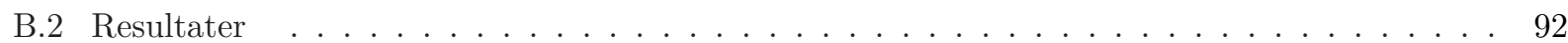

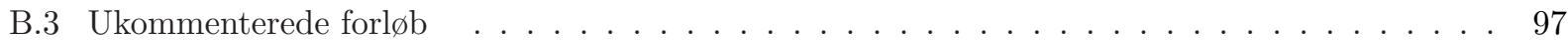

$\begin{array}{ll}\text { C Item-parametre } & 117\end{array}$

D Percentiler i den nye analyse fra 2017 og DNT $2017 \quad 133$

$\begin{array}{lll}\text { E Ministeriets visning af kriteriebaserede scores } & 137\end{array}$

F Georg Breddams notat om nationale test $\quad 139$

G Bilag. Gennemgang af konsekvenser af fejl ved beregning af itemsværhedsgrader 145

G.1 Vurdering af konsekvenser af de forkerte beregninger . . . . . . . . . . . . . . . . . . 150

G.2 Tabel over forkerte og korrekte værdier f . . . . . . . . . . . . . . . . . . . . 150

$\begin{array}{lr}\text { Litteratur } & 155\end{array}$ 


\subsection{Baggrund}

De nationale test har været en væsentlig del af folkeskolens dagligdag siden 2010 og har fået endnu større betydning efter at udviklingen i testresultater blev udpeget som et af succeskriterierne for skolereformen ("Aftale Mellem Regeringen (Socialdemokraterne, Radikale Venstre Og Socialistisk Folkeparti), Venstre Og Dansk Folkeparti Om et Fagligt Løft Af Folkeskolen" 2013). nationale test har været udsat for en del kritik af flere forskellige årsager:

1) Nationale test giver forkerte ikke-valide informationer om elevernes færdigheder (Ravn 2015b; Kousholt 2015).

2) Testresultaterne opfattes som meget usikre blandt andet fordi gentagne målinger af færdighederne vha. nationale test har påfaldende forskelligheder (Riise 2014).

3) Testresultaterne er pædagogisk ubrugelige fordi de er uforståelige og ikke giver oplysninger der er relevante for læreren (Bundsgaard 2018c).

4) Brugen af nationale test som obligatoriske test trækker folkeskolen og fagene i en forkert retning (Bundsgaard 2018b; Bundsgaard og Puck 2016).

5) Afviklingen af testresultaterne presser eleverne unødigt (Bundsgaard og Puck 2016; Wandall, Nørrelund, og Nielsen 2018).

6) Der er mange rapporter om mærkelige og påfaldende testforløb som åbenlyst signalerer at testresultatet må være vildledende og derfor ubrugeligt (Ravn 2015c; Norling 2016).

Punkterne 1, 2 og 6 kan opfattes som spørgsmål vedrørende de måletekniske sider af nationale test. Formålet med det arbejde der beskrives i denne rapport, er at kaste lys over disse problemer ved en analyse af nationale test-resultaterne i dansk, læsning 8. klasse i 2017 og ved en detailanalyse af en række mere eller mindre påfaldende testforløb. Datamaterialet fra 2017 er stillet til rådighed af Undervisningsministeriet mod betaling.

En medvirkende årsag til at vi gik i gang med de mere grundige analyser af nationale tests måleegenskaber og til en række af de konkrete valg af undersøgelsesfoki skyldes matematiklærer på Lemtorpskolen i Lemvig Georg Breddam. Georg Breddam kontaktede Jeppe Bundsgaard i vinteren 2018 for at fortælle om en række observationer han havde gjort i forhold til elevers testforløb. Han havde iagttaget at to tilsyneladende helt ensartede testforløb med samme rækkefølge af rigtige og forkerte svar kunne blive stoppet helt forskellige steder og derved resultere $\mathrm{i}$ to helt forskellige resultater. Han havde desuden en mistanke om at svaret på de første tre-fire spørgsmål var afgørende for det endelige resultat. Georg Breddams opsamling af problemstillingen findes i bilag $\mathrm{F}$.

Georg Breddam havde tidligere skrevet til Styrelsen for Undervisning og Kvalitet (STUK) som har ansvaret for nationale test, og delt sin forundring over konkrete forløb som blandt andet kunne rejse tvivl om hvorvidt en god eller dårlig start kunne fastholde eleven på et tidligt estimeret niveau. Svaret fra STUK lød blandt andet således:

Kort sagt: Dine elevers testforløb ser, i lyset af det adaptive princip, fine ud. De er dog begge eksempler på elever, der enten starter rigtig dårligt eller rigtig godt. Jeg håber, at du kan bruge mine svar. Mange hilsner, NN 
Svar af denne art har vi set i flere sammenhænge når lærere har givet udtryk for tvivl om nationale tests funktionsmåde. Da vi ikke mener at det er en fyldestgørende besvarelse på et legitimt spørgsmål, og da Georg Breddams eksempler (som han har opsummeret i bilag F) var overbevisende og tankevækkende, fandt vi det nødvendigt med en grundig og seriøs undersøgelse af om iagttagelserne faktisk var udtryk for grundlæggende problemer, eller om der var tale om enkeltstående afvigelser eller ekstreme tilfælde, og at testen i øvrigt var velfungerende. Georg Breddam formulerer selv sine spørgsmål således (se bilag F):

- Er testen adaptiv i "folkelig forståelse"?

- Når testen beskrives som adaptiv/tilpasser sig den enkelte elevs niveau, er det for mig påfaldende, hvor meget en god/dårlig start sætter sit præg langt hen i testforløbet i de enkelte profilområder stiafhængighed?

- Hvorledes/hvordan kan testen kategorisere forskellige elever med samme svarmønster vidt forskelligt ved at stoppe forskellige steder i forløbet af items? Nogle elever får mange spørgsmål - mens andre "godkendes" med væsentlig færre spørgsmål i samme profilområde?

Nationale test bygger på en probabilistisk model, og den forudsætter at elever agerer forudsigeligt i forhold til deres dygtighed. Det vil derfor per definition være muligt at finde tilfælde som afviger meget fra det forventede. Denne undersøgelse er derfor blandt andet igangsat for at afgøre om tilsvarende eksempler kan identificeres mere generelt i hele datasættet.

Den anden årsag til at vi har kastet os over de analyser der beskrives i denne rapport, hænger sammen med Undervisningsministeriets igangværende evaluering af de nationale test. Vi deltager begge i en såkaldt ekspertgruppe der rådgiver ministeriet med hensyn til de temaer som en sådan evaluering skal fokusere på. De tekniske sider af denne evaluering er naturligvis et af disse temaer, men vi er bekymrede for at dette tema ikke vil blive taget op på en seriøs måde, fordi der er tale om problemer der kræver en videnskabelig tilgang som ikke kan klares ved hurtige spørgeskemaundersøgelser af den type som de konsulentfirmaer ministeriet normalt benytter sig af, anvender.

Da de måletekniske egenskaber er helt centrale og fordi mange af de problemer som lærere omtaler, kan skyldes sådanne problemer, har det været os magtpåliggende at vise at forskningsbaserede evalueringer ikke nødvendigvis behøver at tage år, men kan klares i løbet af relativt få måneder, selvom der er tale om komplicerede og udfordrende analyser, og selvom det også - som det har været tilfældet i forbindelse med dette arbejde - har været nødvendigt at udvikle metoder til at løse problemer hvor de grydeklare løsninger ikke forelå. Den forskningsbaserede tilgang er årsagen til at det kan lade sig gøre, fordi den sikrer at den nødvendig viden om problemer og metoder er tilgængelige.

Det er af den årsag at vi har foretaget de analyser af den del af nationale test, der beskrives i denne rapport. Resultaterne var ikke givne på forhånd, men vi forventede at rapporten under alle omstændigheder ville være nyttig.

Hvis det viste sig at der ikke var store problemer med testen i læsning i 8. klasse, ville resultaterne være beroligende, selvom nødvendigheden af at se på andre dele stadig ville være til stede. I det tilfælde ville rapporten illustrere hvordan det skal gøres, og at det kan lade sig gøre inden for rimelige tidsrammer hvis opgaven overlades til eksperter der ved hvordan det skal gøres.

Hvis det på den anden side viste sig at der var så store problemer med testen af læsning i 8. klasse at det påvirker testresultater både på elev- og populationsniveau, ville situationen være mere kritisk. Det ville i givet fald være et signal om at læsetesten i 8. klasse ikke kan benyttes i sin nuværende form, og det ville rejse så megen tvivl om resten af de nationale test, at det burde overvejes seriøst at sætte brugen af nationale test i bero indtil de $\varnothing$ vrige dele af nationale test var undersøgt.

For ikke at blive misforstået skal vi understrege at rapporten i givet fald kun kan dokumentere at der enten ikke ser ud til at være nævneværdige problemer, eller at nationale test regner forkert i testen af læsning i 8. klasse og leverer forkerte og dermed vildledende testresultater.

Rapporten præsenterer resultaterne af en række statistiske analyser som bygger på forholdsvis avanceret matematik og beregningsteknik. For at give den interesserede læser mulighed for at få en fornemmelse af 


\subsection{Problemstillingen}

grundlaget for analyserne, vil rapporten indeholde kortfattede forklaringer og beskrivelser af psykometri og pædagogiske test i al almindelighed og om nationale test i særdeleshed. Men det skal understreges at målet med denne rapport ikke er at formidle generel viden om hverken psykometri, pædagogiske test eller nationale test. Formålet er kun at dokumentere vores resultater på en måde som eksperter med kendskab til disse emner vil kunne vurdere og tage stilling til. Den interesserede læser vil kunne benytte sig af referencerne sidst i rapporten i det omfang beskrivelserne ikke slår til.

En nærmere diskussion af årsagerne til eventuelle problemer og den måde de i givet fald skal håndteres på, ligger uden for rammerne af dette arbejde, men vi vil - med udgangspunkt i mange års arbejde med udvikling og afprøvning af pædagogiske test - alligevel tillade os at drage vores foreløbige konklusioner og formulere vores anbefalinger i forventning om at det bliver forstået at disse konklusioner og anbefalinger er oplæg til en nødvendig diskussion af hvad der skal ske med nationale test.

Tak til Georg Breddam og de mange andre lærere der har brugt tid og energi på at dokumetere uforklarlige testforløb og uhensigtsmæssigheder ved nationale test.

Tak også til Elisa Nadire Caeli for meget grundig læsning af rapporten og mange gode kommentaerer og forslag samt korrekturlæsning, ikke mindst. Og tak til Christian Christrup Kjeldsen og Morten Rasmus Puck for at give feedback på tidligere udgaver af denne rapport.

\subsection{Problemstillingen}

Validiteten af testresultaterne forudsætter at testforløbene passer til en psykometrisk skalamodel. Psykometrien omfatter flere sådanne modeller, fx modeller for konfirmatoriske faktoranalyser eller såkaldte IRT-modeller (Item Response Theory). Af disse modeller er den såkaldte Rasch-model den mest interessante model fordi den udover at have en række specielle egenskaber også er den enkleste og lettest forståelige model.

Rasch-modellen der har været anvendt i forbindelse med udviklingen af nationale test, vil blive introduceret i kapitel 3.3. På dette tidspunkt er det tilstrækkeligt at gøre opmærksom på at en såkaldt Rasch-analyse indeholder følgende trin:

1) Estimation af opgavernes sværhedsgrader.

2) Afprøvning af testforløbenes tilpasning til modellen (herunder om der er system i hvilke opgaver eleverne besvarer rigtigt, og hvilke de besvarer forkert).

3) Beregning af elevernes dygtighed ud fra oplysninger om hvor mange opgaver der er besvaret korrekt, og oplysninger om sværhedsgraderne på de opgaver som eleverne har besvaret.

Tilpasning mellem testforløb og model og præcise oplysninger om opgavernes sværhedsgrader er vigtige for alle test, uanset om der er tale om lineære test hvor alle elever besvarer de samme opgaver, eller om adaptive test som nationale test, men kravene er væsentlig mere centrale for adaptive test end for lineære test. Raschmodellen er som omtalt en probabilistisk model, hvilket betyder at det forventes at elever kan svare rigtigt på opgaver der egentlig er "for svære" for dem, og forkert på opgaver man kunne forvente de kunne svare rigtigt på.

I lineære test kan problemerne være begrænsede fordi alle elever svarer på de samme opgaver, og fordi dygtigheden vurderes ud fra antallet af korrekte svar. Skulle der være en enkelt opgave der falder ved siden af, eller skulle der være problemer med sværhedsgraderne, er det problemer der gælder på samme måde for alle elever. Det vil stadig være de dygtigste elever der har mange rigtige svar, og de mindre dygtige der har færre.

I adaptive test hvor den adaptive algoritme udvælger opgaver ud fra det aktuelle estimat af dygtigheden og ud fra algoritmens viden om opgavernes sværhedsgrader, kan fejl i model og/eller sværhedsgrader være 
$\varnothing$ delæggende fordi den adaptive algoritme systematisk vælger forkerte opgaver og beregner forkerte estimater af dygtigheden i løbet af processen.

I forbindelse med adaptive test vil konsekvenserne af disse fejl være mere usikre målinger af dygtighed, og det vil især betyde at der kan være store forskelle på gentagne målinger af den samme elev fordi de fejl der vil være i det første udvalg af opgaver, vil være nogle andre, end dem der er i det andet udvalg.

Selvom den betydelige usikkerhed i nationale test har kunnet bortforklares med at resultater fra pædagogiske test altid forekommer, står det grundlæggende problem tilbage. Giver nationale test mere usikre resultater end man kan forvente, og skyldes det (blandt andet) at der er problemer med den psykometriske skalamodel og/eller de sværhedsgrader som den adaptive algoritme bruger når opgaverne udvælges og dygtigheden beregnes?

De nationale test blev udviklet fra 2007-2010 og sværhedsgraderne og tilpasningen til Rasch-modellen vurderet ud fra et i psykometriske sammenhænge meget stort datamateriale. Dokumentationen af resultaterne (som er den ene af os bekendt) er aldrig offentliggjort.

Siden da er der tilføjet nye opgaver og fjernet gamle opgaver, og sværhedsgraderne er efter sigende (Ravn 2015a) blevet genberegnet i 2014. Vi er ikke bekendt med at der eksisterer dokumentation af denne genberegning.

Der er flere mulige grunde til at opgavernes sværhedsgrader kan have ændret sig siden 2010:

1) Testsituationen i forbindelse med indsamling af testresultater i 2007-2009.

2) Teaching-to-the-test i form af træning af eleverne i at løse den slags opgaver som findes i nationale test.

3) Ændring af elevernes oplevelse af testsituationen fra low-stakes til high-stakes.

Det betyder ikke nødvendigvis at sværhedsgraderne har ændret sig, men det er ikke en selvfølge at de ikke har ændret sig.

Der er derfor grundlag for at analysere aktuelle data fra nationale test og at forsøge at besvare følgende to spørgsmål for at afprøve om nationale test estimerer dygtigheden på den rigtige måde:

1) Lever nationale tests opgaver op til Rasch-modellens krav?

2) Benytter nationale test de korrekte sværhedsgrader?

Og hvis disse spørgsmål ikke besvares positivt at stille spørgsmålene:

3) Hvilke konsekvenser har de identificerede problemer?

4) Er de estimater som nationale test leverer, tilstrækkeligt sikre?

De fire spørgsmål kan siges at være centrale. Hvis de besvares positivt, kan man argumentere for at nationale test generelt fungerer som den skal teknisk set. Hvis det kun er de tre første der besvares positivt, er det nødvendigt at se på årsagerne til at usikkerheden er for stor, og om det evt. skyldes en fejl i programmeringen af den adaptive algoritme, eller at der ikke er tilstrækkelige opgaver til at den adaptive algoritme altid kan finde en opgave der passer til elevens niveau.

Endelig betyder det forhold at nationale test fungerer som den skal, ikke at der ikke kan være problemer i forbindelse med enkelte testforløb. Rasch-modellen er probabilistisk så der er altid en vis sandsynlighed for at tilsyneladende usædvanlige testforløb vil dukke op. Spørgsmålet er derfor ikke om testforløbene er usædvanlige. Spørgsmålet er om de er så usandsynlige at det er vanskeligt at tro på at det kun er elevens dygtighed og sværhedsgraderne af de stillede opgaver der ligger bag testresultatet, således at vurderingen af elevens dygtighed er utroværdig. Den analyse som denne rapport præsenterer, skal også kaste lys over dette spørgsmål og vise hvorledes man kan opdage usandsynlige forløb. 


\subsection{Plan for analysen}

For at besvare disse spørgsmål vil analysen af nationale test-data fra 2017 omfatte følgende:

1) Ny estimation af sværhedsgraderne og en sammenligning med sværhedsgraderne i item-banken

2) En afprøvning af tilpasningen til Rasch-modellen

3) En vurdering af usikkerheden på målingerne ifølge 2017-analysen

4) En analyse af fordelingen af dygtigheden ifølge 2017-analysen og en sammenligning med fordelingen af dygtigheden ifølge nationale tests beregninger

5) En detailanalyse af en række enkeltstående forløb for at illustrere hvorledes den adaptive algoritme fungerer, og for at afprøve om tilsyneladende usædvanlige forløb også er usandsynlige (signifikante), og hvilke konsekvenser det i så fald har for målingerne af dygtigheden.

Spørgsmål 2 er et kompliceret spørgsmål som vil blive besvaret i en efterfølgende rapport. Denne rapport har derfor fokus på de fire øvrige spørgsmål.

\subsection{Tilføjelse til 2. udgave}

Dette er 2. udgave af rapporten. Denne udgave har vi udarbejdet efter en henvendelse fra Morten Rasmus Puck. Han havde ved læsning af rapporten opdaget at der var en række fejl i den tabel over itemsværhedsgrader der er gengivet i bilag C. Ved gennemgang af vores scripts til produktion af de data der indgår i tabellen, opdagede vi at der var sket en fejl som betød at item-location for polytome items (som kun findes i profilområde 3) var blevet indskrevet i profilområde 1 og derved havde overskrevet de korrekte sværhedsgrader. Det bet $\varnothing$ d at 90 items havde fået forkerte sværhedsgrader i profilområde 1, og at 90 items i profilområde 3 var sat lig med den første kategoris threshold. Profilområde 2 er ikke påvirket af fejlen. Vi har alene anvendt disse værdier i vores illustration af forskellen på itemsværhedsgrader i afsnit 4.3.1, og fejlen vedrører således alene vores behandling af forskelle i itemsværhedsgrader mellem 2017-analysen og DNT-analysen. I bilag G gennemgår vi konsekvenserne af denne fejl. Vi konkluderer på den baggrund at der ikke er grund til at ændre i konklusionerne i rapporten.

Vi vil benytte lejligheden til at takke Morten Rasmus Puck mange gange for at have studerent rapporten så grundigt og identificere den yderst beklagelige fejl. 
Forfatterne, læsevejledning og resultater

\section{$2.1 \quad$ Forfatterne}

Rapportens forfattere har begge været optaget af nationale test fra forskellige perspektiver i en lang årrække.

Svend Kreiner er professor emeritus ved Center for Biostatistik, Københavns Universitet. Svend Kreiner har forsket i test af elevers dygtighed siden slutningen af 60'erne. Han har publiceret en lang række forskningsartikler om test i internationalt anerkendte tidsskrifter og bøger. Han har gennem alle årene bidraget til udviklingen af tests inden for blandt andet matematik og læsning som bruges i skolen den dag i dag. I årene 2007-2010 bistod han Undervisningsministeriet ved udviklingen af nationale test, hvor han bl.a. udviklede nogle af de statistiske værktøjer som var nødvendige ved designet af en adaptiv test. Siden hen har han fungeret som sparringspartner for ministeriet ved spørgsmål om nationale test, og han har skrevet en række rapporter bl.a. om validering af testens resultater.

Jeppe Bundsgaard er professor MSO i fagdidaktik og it med særlig henblik på dansk ved Danmarks institut for Pcedagogik og Uddannelse (DPU), Aarhus Universitet. Jeppe Bundsgaard har skrevet en række artikler om test og den pædagogiske brug af test fra et fagdidaktisk perspektiv. Han er dansk leder af den internationale IEA-undersøgelse International Computer and Information Literacy Study (ICILS 2013 og 2018), og han deltager som fagekspert nationalt og internationalt i PISA-undersøgelsen. Han har desuden deltaget i udviklingen af en række innovative computerbaserede test af elevers designkompetencer, samarbejdskompetencer mv.

Begge forfattere er udpeget til Undervisningsministeriets rådgivningsgruppe om evaluering af nationale test.

\subsection{Rapportens opbygning}

Denne rapport indeholder en omhyggelig analyse af de måletekniske egenskaber af de nationale test i læsning i 8. klasse i 2017. Analyserne bygger på svarene på alle opgaver fra alle 48.481 elever i 8. klasse i 2017. Analysen er foretaget ved hjælp af den samme Rasch-model som blev anvendt i forbindelse med udviklingen og afprøvningen af de nationale test. Eventuelle forskelle på det som analysen af datamaterialet fra 2017 måtte afsløre, i forhold til det som de nationale test producerer, kan derfor ikke skyldes at denne analyse bruger andre metoder og stiller andre krav til test, end dem der blev brugt i forbindelse med udviklingen af de nationale test.

Rapporten indledes i kapitel 3 med en præsentation af nationale test og af den statistiske model der ligger bag ved testen. I dette kapitel præsenteres også det anvendte datasæt. De to følgende kapitler (4 og 5$)$ præsenterer analyserne og resultaterne af disse. I det sidste kapitel (kapitel 6) præsenteres de samlede konklusioner, og det diskuteres hvad konsekvenserne af problemerne er, og hvad der kan gøres for at rette op på disse problemer. 


\subsection{Resultaterne}

Resultaterne af analysen kan ganske kort opsummeres på følgende måde, hvor det skal understreges at vores analyse kun kan fortælle noget om nationale tests målinger af elevers læsefærdighed i 8. klasse.

1) Nationale test anvender opgavernes sværhedsgrader til at udvælge opgaver til elever og til at beregne mål for hvor dygtige eleverne er. Disse sværhedsgrader er forkerte, og der var i 2017 mange tilfælde af meget store forskelle på de sværhedsgrader som nationale test benytter, og de sande sværhedsgrader.

2) Konsekvensen af at nationale tests sværhedsgrader er forkerte, er at beregningerne af dygtigheden er forkert og kan være direkte vildledende. Analyserne i kapitel 4 giver flere eksempler på at det rent faktisk er tilfældet, både når man ser på testresultater for enkelte elever, og når man ser på fordelingen af læsefærdigheden i 2017. Nationale tests resultater tegner med andre ord et forvrænget billede af situationen.

3) Anvendelsen af forkerte sværhedsgrader betyder at den adaptive algoritme vælger opgaver på en uhensigtsmæssig måde som - selvom målingerne af dygtigheden ikke havde været systematisk forkerte, og selvom analyserne også viser at den adaptive algoritme fungerer som den skal - ville forringe sikkerheden på målingerne. Resultaterne i kapitel 4 og 5 giver flere eksempler på at dette ikke blot er noget der kan påvises at følge logisk af problemerne med sværhedsgraderne, men at det også kan ses i data fra 2017.

4) Undersøgelsen i kapitel 4 af opgavernes tilpasning til eleverne viser at der i to af de tre områder som eleverne testes i (profilområder), kun er et meget begrænset udvalg af opgaver til dygtige og meget dygtige elever. Det kan betyde at disse elever vil opleve at få de samme opgaver i den obligatoriske test som de allerede har fået i den frivillige test, og det betyder at de skal besvare flere opgaver end nødvendigt for at opnå tilstrækkelig sikkerhed på resultatet.

5) Med hensyn til usikkerheden viser analyserne også at ministeriets beslutning om at slække på kravene til målingernes sikkerhed fører til testresultater der er så usikre at de er uanvendelige på elevniveau. Dette problem ville også være der selvom der ikke var problemer med opgavernes sværhedsgrader, men fejlene i sværhedsgraderne forstærker problemet med usikkerheden.

6) En undersøgelse af datas tilpasning til Rasch-modellen i kapitel 4 viser at der ikke er belæg i data for at sige at de tre profilområder i læsning måler én og samme færdighed, men analysen tyder på at det kan give mening at se afkodning og tekstforståelse som én dimension. En sådan sammenlægning af profilområder ville kunne forøge sikkerheden på elevernes resultater.

7) Analyserne i kapitel 5 viser at der er situationer hvor elevens færdigheder i læsning ikke kommer til udtryk i dele af testforløbet, og at beregningerne derfor systematisk undervurderer hvor godt eleven læser. De nævnte situationer, hvor dele af testforløbet er mislykkedes, er hyppigst i starten af forløbet, men forekommer også undervejs. Denne analyse kan ikke sige noget konkret om hvor ofte der er problemer med dele af testforløbene, men vi kan konstatere at det var særdeles let at finde sådanne eksempler ved blot at kigge datamaterialet igennem. Af den årsag forventer vi at hyppigheden af delvist mislykkede testforløb hvor elevernes færdigheder undervurderes, er med til at tegne et mere pessimistisk billede af danske elevers læsefærdigheder, end der er belæg for.

Kapitel 6 uddyber og diskuterer årsager til og konsekvenser af konklusionerne. I første omgang er det tilstrækkeligt at sige følgende med hensyn til konsekvenserne:

a) Problemerne med nationale tests målinger af læsefærdigheder i 8. klasse er så store at man nøje bør overveje om det er fagligt, pædagogisk og policy-mæssigt forsvarligt at fortsætte med at bruge denne del af nationale test før man har løst problemerne. Hvorvidt problemerne skal løses ved at erstatte nationale tests sværhedsgrader med sværhedsgrader baseret på aktuelle data, eller om der skal andre og mere drastiske løsninger til, kan analyserne i denne rapport ikke sige noget om.

b) Analysen i denne rapport er begrænset fordi den kun undersøger læsefærdighed i 8. klasse. 
Forskellene på nationale tests resultater og resultaterne af 2017-analysen er imidlertid så slående at man skal være meget optimistisk hvis man forventer at lignende problemer ikke findes andre steder i nationale test. Af denne årsag anbefales det at man også nøje overvejer om det er hensigtsmæssigt at fortsætte med de $\varnothing$ vrige områder af nationale test indtil man har undersøgt om tilsvarende problemer findes i disse, og indtil man har besluttet hvad der i givet fald skal gøres ved det.

c) Uanset hvad resultatet af overvejelserne bliver, skal lærere være opmærksomme på at testforløb kan være helt eller delvist mislykkede, at det kan lade sig gøre at undersøge det, og at man i givet fald bør forkaste testresultatet og undlade selv at bruge det samt undlade at orientere forældrene om andet end at testforløbet er slået fejl.

d) I forventning om at de sværhedsgrader som nationale test benytter, var korrekte i 2014, bliver konsekvensen af 2017-analysen at det ikke giver mening at sammenligne testresultater fra 2014 og 2017. At eventuelle forskydninger i fordelingerne af testresultaterne i form af ændrede gennemsnitsværdier eller ændringer i antallet af elever med gode eller dårlige testresultater ikke fortæller om læsefærdighederne har ændret sig og i givet fald på hvilken måde. Som følge heraf er det nødvendigt at gøre opmærksom på at testresultater fra nationale test ikke umiddelbart kan bruges til at vurdere om fordelingen af læsefærdigheder har ændret sig i positiv eller negativ retning som konsekvens af skolereformen. 


\section{De nationale test, måleegenskaber og Rasch-modellen}

Dette kapitel introducerer kort til nationale test og beskriver dernæst dels de krav til skalaer som var vejledende i forbindelse med udviklingen af de nationale test i årene fra 2006 til 2009 og for vores analyser af datamaterialet fra 2017, dels det datamateriale som vi har benyttet i vores analyser.

\subsection{De nationale test}

Elever i 2. til 8. klasse tager nationale test i fire forskellige fag eller fagområder fordelt over de syv årgange. Dansk, læsning tages i 2., 4., 6. og 8. klasse, og det tester som navnet siger, alene (dele af) læseområdet, men ikke de andre områder af danskfaget. Det er obligatorisk at deltage i nationale test for elever i folkeskolen. Ud over den obligatoriske test der finder sted i marts-maj i foråret, kan læreren eller skolen eller kommunen beslutte at eleverne skal tage testen "frivilligt" i efteråret før og i løbet af året efter den obligatoriske test. Testen er berammet til at tage 45 minutter. Men hvis ikke algoritmen er nået frem til en tilstrækkelig lav usikkerhed (SEM), kan læreren forlænge testforløbet.

I forbindelse med vedtagelsen af nationale test i 2006 blev det besluttet at man skulle måle tre såkaldte profilområder inden for hvert fagligt område. I dansk, læsning er de tre profilområder sprogforståelse, afkodning og tekstforståelse. Profilområderne svarer til det der i psykometrisk sprogbrug typisk omtales som dimensioner. Hvorvidt der i virkeligheden er tale om tre dimensioner der i psykometrisk forstand er forskellige, og hvorfor der netop skal være tre dimensioner i alle fagområder, er åbne spørgsmål som ikke er blevet besvaret, men som kan have uheldige konsekvenser for usikkerheden på målingerne.

Når man udvikler opgaver til en test, kan man vælge mange typer af opgaver. Det mest kendte er multiple choice, hvor testtageren får et spørgsmål og fx tre eller fire svar at vælge imellem (det kan fx være sætninger eller billeder ${ }^{1}$. Det anvendes også i nationale test. Multiple choice-opgaver er blandt andet karakteriseret ved at det kan være vanskeligt at forudsige hvor svær opgaven er, fordi chancerne for at svare rigtigt afhænger af de forkerte svarmuligheder. Hvis de åbenlyst er forkerte, er der kun det rigtige svar tilbage, hvilket kan gøre et vanskeligt spørgsmål meget let. Desuden anvendes såkaldte ordkcedeopgaver, hvor eleven skal sætte to streger i en kæde af bogstaver og derved danne tre ord. En tredje typisk opgave er såkaldte cloze-test (Taylor 1953) hvor eleven skal læse en tekst og undervejs angive hvilket ord der passer bedst i sammenhængen ud fra fx tre eller fire mulige. Eksempler på disse opgaveformater fra nationale test kan ses i figur 3.1.

\footnotetext{
${ }^{1}$ Faktisk er der tale om single choince fordi eleven skal vælge ét svar blandt flere mulige. Men i de fleste sammenhænge betegnes det multiple choice.
} 


\begin{tabular}{l} 
Nationale test - Mozilla Firefox \\
\hline (i) https://elev.testogprøver.dk/demo/0104 \\
\hline Sæt et $\mathrm{X}$ \\
$\square$ En, der laver møbler og døre. \\
$\square$ En, der er god til at snyde. \\
$\square$ En, der er meget langsom. \\
$\square \mathrm{En}$, der skraber sne fra vejene.
\end{tabular}

testogprøver.dk

\begin{tabular}{|c|c|c|}
\hline Nationale test - Mozilla Firefox & & $\mathbf{x}$ \\
\hline (i) https://elev.testogprøver.dk/demo/0104 & ...公 & $\equiv$ \\
\hline Hvilke ord passer i teksten? & \multicolumn{2}{|c|}{ Opgave 2} \\
\hline
\end{tabular}

Klik på svar
Virtus' far arbejdede for politiet. I kæ/deren under det hus, hvor Virtus og hans far
boede, var der fængselsceller.
En dag, da Virtus kom hjem fra skole, holdt der en politibil uden for hans hoveddør.
Det var en af de store (ambulancer, politibiler, brandbiler, kranbiler) med jerngitter for
ruderne, og Virtus vidste godt, hvad det betød: Der var kommet en ny (patient,
brandmand, fange, håndværker) i kælderen. Det var kun tirsdag, og det betød, at der
var fem dage, til fangen skulle (fejres, vaskes, halshugges, hyldes) på torvet. Virtus
håbede, at det var en af de stille, (fredelige, larmende, farlige, voldsomme) fanger, der
ikke bandede og lovede ham tæv.
I døren mødte han to politibetjente, der var på vej ud. De så vrede ud, og den ene
holdt en klud rundt om sin pegefinger. Der var blod på (glasset, nålen, kluden, kniven)
.

testogprøver.dk

$=\frac{\text { Nationale test - Mozilla Firefox }}{} \frac{\times}{\text { (i) https://elev.testogprøver.dk/demo/0104 }}$

Eksempel:

isbilkoris|bil|ko

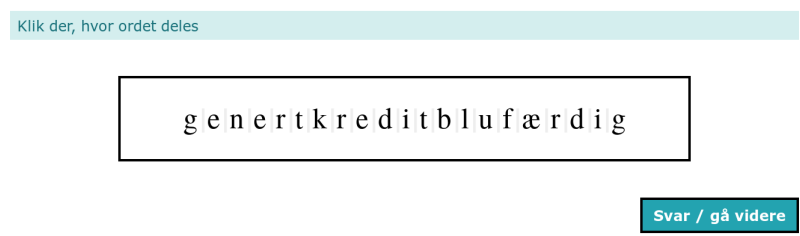

\section{Pa Færøerne betragtes kong Sverre, der regerede i Norge i 25 ăr til sin død i 1202, som det tætteste på at være en ægte færøsk konge. Sverre Sigurdsson blev født I Norge i 1151 , men voksede op i Kirkjubøur på Færøerne, hvor den færøske biskop satte ham i præstelære. Men da Sverres mor fortalte ham, at han var søn af den norske konge Sigurd Munn, fik Sverre nye ambitioner. Han drog til Norge for at kræve sin ret, og efter mange år og mange kampe lykkedes det i 1177 Sverre at blive konge af Norge. I Kirkjubøur har man stadig Sverreshule - en lille grotte, hvor den senere konge opholdt sig som dreng.}

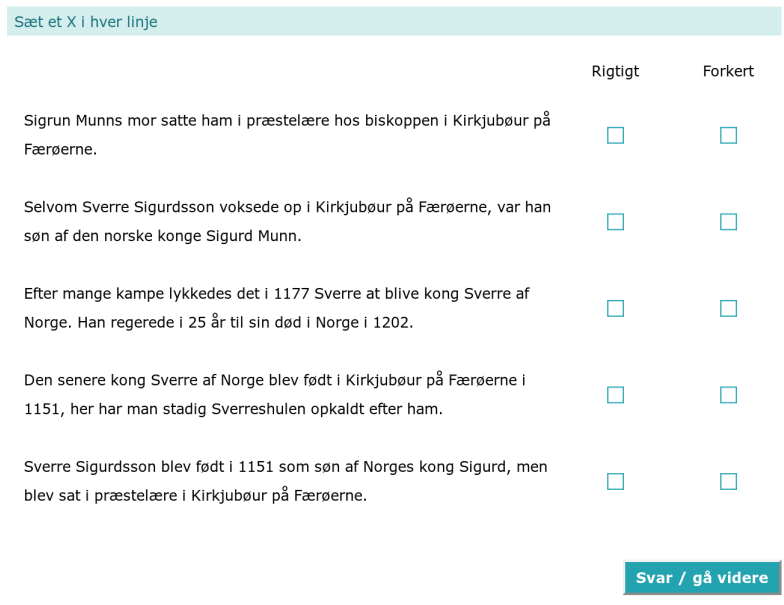

testogprøver.dk

Figur 3.1 Eksempler på opgaveformater og opgaver i nationale test. Fra demo.testogprøver.dk.

Clozetests er kendetegnet ved det man kalder lokal afhæengighed, dvs. at hvis man har et ord korrekt, er der større sandsynlighed for også at have de øvrige ord i samme tekst korrekte. Det er et problem i Raschmodellen, og derfor kan man vælge at tælle antallet af rigtige delopgaver i stedet for at betragte hvert valg som én opgave. Sådanne opgaver kaldes ofte superitems eller polytome opgaver. Da man så ikke bare har items som kan være rigtige (1) og forkerte (0), men items som $\mathrm{fx}$ kan have værdierne $0,1,2,3$ osv., skal man bruge den nedenfor omtalte partial credit-model. 


\subsection{Krav til skalaer}

De tekniske psykometriske ${ }^{2}$ krav til gode test drejer sig dels om validitet og dels om usikkerhed og reliabilitet.

Rosenbaum (1989) opsummerer kravene til valide test på følgende måde:

a) Unidimensionalitet. Svarene på opgaver i en test må kun afhænge systematisk af én færdighed, der i princippet kan måles på en kvantitativ skala. På denne skala er en elev med en høj værdi dygtigere end en elev med en lav værdi, og forskellen på og/eller forholdet mellem de to tal kan betragtes som et udtryk for, hvor meget dygtigere den dygtigste elev er i forhold til den mindre dygtige.

b) Monotonicitet. For samptlige opgaver i testen skal sandsynligheden for et rigtigt svar på opgaven blive større og større, jo dygtigere eleven er.

c) Lokal uafhængighed. Sandsynligheden for at elev svarer rigtigt på en opgave, må ikke påvirke eller påvirkes af svarene på de øvrige opgaver.

d) Sandsynligheden for at en elev svarer rigtigt på en opgave, må ikke afhænge systematisk af andet end elevens dygtighed. Testen må med andre ord ikke indeholde opgaver der fx favoriserer drenge frem for piger, eller - i internationale undersøgelser - opgaver der favoriserer elever fra et land i forhold til andre.

Derudover var det i forbindelse med afprøvningen af nationale test et krav at opgavernes sværhedsgrader kan måles kvantitativt på den samme måde som det var tilfældet med dygtigheden ${ }^{3}$. Og det var et krav at opgaverne fungerer homogent, hvilket vil sige at forskellen på sværhedsgraden for to opgaver er den samme for de dygtigste elever og for de mindre dygtige elever.

Alle psykometriske skalamodeller er probabilistiske. De udtrykker sandsynligheden for at en elev kan svare rigtigt på en opgave, som en funktion af dygtigheden, sværhedsgraden og evt. andre forhold omkring opgaven og testsituationen. Af denne grund vil alle beregninger af hvor dygtige eleverne er, være statistiske estimater af dygtigheden som - ligesom alle andre statistiske estimater - vil være behæftet med en vis usikkerhed. I almindelige statistiske analyser måles graden af usikkerheden ved en såkaldt standardfejl (standard error, SE). Det er også tilfældet i forbindelse med pædagogiske test hvor standardfejlen omtales som standard error of measurement (SEM).

I alle statistiske analyser er det et krav at man forsøger at reducere usikkerheden i resultaterne ved at bruge metoder der reducerer standardfejlen til det mindst mulige. Det er også tilfældet i forbindelse med nationale test hvor man valgte et adaptivt testsystem fordi man kan vise at adaptive test resulterer i de mindst mulige SEM-værdier - vel at mærke hvis, og kun hvis, forudsætningerne for beregningen af dygtigheden og SEM er i orden.

I forbindelse med udviklingen af nationale test definerede man et krav om at SEM ikke måtte være større end 0.30. Baggrunden for denne beslutning vil ikke blive beskrevet her, selvom det ikke er uinteressant. Det viste sig nogle år efter testen var taget i brug, at dette mål ikke var nået, og at udviklerne af det adaptive system havde sat niveauet til 0,55 og ikke 0,3 (Ravn 2014; Wandall 2010; Styrelsen for It og Læring 2015). Konsekvenserne af denne beslutning vil blive diskuteret i forbindelse med vores konklusioner. På nuværende tidspunkt kan vi kun tage beslutningen til efterretning og vurdere om nationale test rent faktisk lever op til kravene.

Udover usikkerheden udtrykt ved SEM interesserer man sig i forbindelse med afprøvning af test også for et fænomen som i psykometrisk sprogbrug omtales som reliabilitet. Ordvalget er uheldigt fordi personer uden kendskab til psykometri opfatter begrebet som et generelt spørgsmål om hvor troværdige testresultaterne

\footnotetext{
${ }^{2}$ Psykometri er videnskaben om at måle (-metri) psykiske fænomener.

${ }^{3}$ Vi betegner elever der er i stand til at svare rigtigt på svære opgaver, som dygtige elever. Elever som kun kan svare på lettere opgaver, betegner vi som mindre dygtige elever. Betegnelsen gælder alene for det område eleven har svaret på opgaver inden for. Elever kan godt være dygtige inden for ét område og mindre dygtige inden for andre.
} 
er (Styrelsen for It og Læring 2016b). For at forhindre misforståelser er det derfor nødvendigt at definere reliabiliteten.

Reliabiliteten afhænger af usikkerheden (SEM), men den afhænger i lige så høj grad af spredningen af eleverne i den population man interesserer sig for. Definitionen er:

$$
\text { Reliabilitet }=\frac{\text { Variansen af dygtigheden }}{\text { Variansen af dygtigheden }+S E M^{2}}
$$

Det vil sige at reliabiliteten forbedres jo mere elevernes scorer spreder sig, og forværres jo mindre spredningen er. Hvis alle elever er lige dygtige, vil reliabiliteten altid være lig med nul selvom testen i sig selv er meget sikker.

Reliabilitetsmålet er en abstrakt størrelse som kan være vanskelig at fortolke. Den bedste måde at forstå den på er ved at bemærke at sandsynligheden for at den dygtigste af to tilfældigt udvalgte elever vil få det bedste testresultat, vil være tæt på (men ikke helt præcist lig med) reliabiliteten. Hvis reliabiliten fx er 0,8, vil den bedste af to tilfældigt udvalgte elever blive vurderet som den bedste i otte ud af ti målinger og som den dårligste $\mathrm{i}$ to af disse ti målinger.

I forbindelse med test der skal anvendes på individniveau, finder man ofte et krav om et reliabiliteten skal være lig med 0,9 eller bedre (Hale og Astolfi 2014; Wells og Wollack 2003). I populationsanalyser (fx PISA og IEA-unders $\varnothing$ gelserne), hvor det ikke drejer sig om enkelte elever, er kravet at reliabiliteten skal være større end 0,7 og helst større end 0,8 .

Baggrunden for disse krav vil ikke blive diskuteret i denne rapport hvor formålet først og fremmest er at undersøge om nationale test leverer lige så gode og pålidelige testresultater som man lover.

\subsection{Rasch-modellen}

Georg Rasch var matematiker og arbejdede blandt andet ved Danmarks Pædagogiske Institut i 1950-60'erne. I den periode udviklede han det der i dag er kendt som Rasch-modellen (Rasch 1960).

I virkeligheden er Rasch-modellen en hel familie af item-responsmodeller som deler en række specielle og særdeles nyttige statistiske egenskaber.

Den oprindelige Rasch-model blev første gang omtalt på dansk i Rasch (1958) og senere på engelsk i Rasch (1960). Modellen beskriver sandsynligheden for at en elev svarer rigtigt på en opgave i en pædagogiske test som en funktion af forskellen på elevens dygtighed, $\theta$ (theta), og opgavens sværhedsgrad, $\beta$ (beta):

$$
\text { Sandsynlighed for korrekt svar }=\frac{e^{\theta-\beta}}{1+e^{\theta-\beta}}
$$

Bortset fra at eksponentialfunktionen optræder i formlen, er der tale om en i princippet meget enkel model der blot siger det intuitivt indlysende at en elevs sandsynlighed for at svare rigtigt på en opgave afhænger af to ting (og kun disse to ting), nemlig elevens dygtighed (der ofte benævnes med det græske bogstav theta, $\theta$ ) og opgavens (itemmets) sværhedsgrad (der ofte benævnes beta, $\beta$ ).

Ifølge denne model er sandsynligheden for et korrekt svar lig med 50 procent hvis dygtigheden er lig med sværhedsgraden: Eleven får altså ikke en let opgave, hun får en udfordrende opgave som hun har en fair chance for at kunne besvare.

Raschs oprindelige model, hvor der kun er to mulige udfald, rigtigt eller forkert, omtales i dag som Raschmodellen for dikotome items. Denne model er senere, først af Rasch selv i 1961 og 1962 og senere af andre udvidet til modeller for polytome items hvor der kan scores fra 0 til et vist antal point afhængig af hvor 
stor en del af opgaven der er besvaret rigtigt. Formlerne for denne model, der som regel omtales som en partial credit model (PCM), er mere komplicerede. Hvis der kan scores fra 0 til m point på opgaven, er sandsynligheden for at der scores $\mathrm{x}$ point givet ved:

$$
\text { Sandsynlighed for x point }=\frac{e^{\sum_{j=0}^{x} \theta-\beta_{j}}}{\sum_{z=0}^{m} e^{\sum_{j=0}^{z} \theta-\beta_{j}}}
$$

hvor $\mathrm{m}$ er det maksimale antal point på itemmet.

I PCM-modellen omtales $\beta$-parametrene normalt som "tærskelværdier". Læseren er undskyldt hvis hun har vanskeligt ved at gennemskue præcis hvilken fortolkning disse parametre har. Det har alle andre også. Det der er værd at bemærke, er at sandsynlighederne defineres af forskellene på dygtigheden og tærskelværdierne, og at det forventede antal point er en monotont voksende funktion af dygtigheden. Jo dygtige, jo flere point på opgaven.

Rasch-modellen indeholder ingen forudsætninger om at dygtigheden fordeler sig på en bestemt måde i en population af elever. Sådanne forudsætninger optræder til gengæld i den generalisering af Rasch-modellen der omtales som Mixed-Coefficient Multinomial Logit Model (MCMLM) eller Multidimensional Random Coefficients Multinomial Logit Model (MRCMLM) (Adams, Wilson, og Wang 1997), og som blandt andet har været anvendt i analyserne i denne rapport.

Disse modeller har den styrke at de tilbyder en enkel og naturlig generalisering af den endimensionelle Rasch-model der kun måler én færdighed ad gangen, til én samlet model for flere test der hver for sig måler forskellige færdigheder.

Da nationale test ikke måler én færdighed, men derimod tre kvalitativt forskellige færdigheder som i nationale tests private terminologi omtales som profilområder, er MCMLM-modellen særdeles relevant at anvende. For testen i dansk, læsning er disse profilområder sprogforståelse, afkodning og tekstforståelse.

En MCML-model for nationale test måler altså dygtigheden for tre forskellige færdigheder, $\left(\theta_{1}, \theta_{2}, \theta_{3}\right)$. Modellen bygger på følgende forudsætninger:

a) At opgaver knyttet til et bestemt profilområde kun afhænger af dygtigheden knyttet til profilområdet.

b) At opgaverne til et bestemt profilområde isoleret set opfører sig som opgaver fra en endimensionel Rasch-model.

c) At fordelingen af de tre dygtighedsgrader $\left(\theta_{1}, \theta_{2}, \theta_{3}\right)$ følger en flerdimensionel normalfordeling hvor sammenhængen mellem de tre færdigheder er lineær og kan beskrives fyldestgørende ved korrelationen mellem dygtighedsgraderne.

MCML-modellen er således blot en flerdimensionel Rasch-model.

Den statistiske analyse estimerer modellens parametre og afprøver om data (dvs. svarene på opgaverne) opfører sig som Rasch-modellen forventer. Detaljerne i metoderne vil ikke blive gennemgået her, men der er en ting som skal understreges.

Estimatet af en elevs dygtighed inden for et bestemt profilområde er en relativt kompliceret ikke-lineær funktion af det samlede antal korrekte opgaver eller det samlede antal point eleven har opnået, som ikke fordi det er en Rasch-model og ikke en af de andre skalamodeller - afhænger af hvordan eleven har scoret pointene. Hvis tre elever hver for sig har seks rigtige ud af ti opgaver, vil de få det samme estimat af dygtigheden selvom svarmønstret for den ene var $(0,0,0,0,1,1,1,1,1,1)$, for den anden var $(0,1,1,0,1,0,1,1,1,0)$ og for den tredje var $(1,1,1,1,1,1,0,0,0,0)$. Det første og det sidste mønster ser måske mærkelige ud, men hvis der fx var tale om ti lige vanskelige opgaver ville de tre forløb faktisk have præcis samme sandsynlighed for at forekomme.

Eller med andre ord: Hvis opgaverne virkelig opfører sig som Rasch-modellen kræver - og kun hvis det er tilfældet - er det ligegyldigt hvorledes pointene er scoret. 
Tabel 3.1 Oversigt over den bedst mulige "standard error of measurement" (SEM) som funktion af antal besvarede opgaver

\begin{tabular}{rr}
\hline Antal opgaver & Mindste mulige SEM \\
\hline 1 & 2,00 \\
3 & 1,15 \\
5 & 0,89 \\
10 & 0,63 \\
20 & 0,45 \\
30 & 0,37 \\
40 & 0,32 \\
50 & 0,28 \\
60 & 0,26 \\
70 & 0,24 \\
\hline
\end{tabular}

\subsection{Adaptive test}

De nationale test er som nævnt adaptive og benytter en adaptiv algoritme der løbende beregner estimater af dygtigheden ud fra oplysninger om sværhedsgraderne for de opgaver der allerede er besvaret, og antallet af disse opgaver der er besvaret korrekt, hvorefter der vælges en ny opgave med en sværhedsgrad der ligger tæt på det aktuelle bud på dygtigheden (Styrelsen for It og Læring 2015). Interessen for adaptive test udspringer af bekymringen for usikkerheden i testresultaterne. Usikkerheden måles ved hjælp af standardfejlen (SEM) på estimatet af dygtigheden. SEM kan vises at være (næsten) lig med 1 divideret med kvadratroden på den såkaldte test-information.

Test informationen er på sin side defineret som summen af den information som svaret på en enkelt opgave bidrager med. Denne såkaldte iteminformation har to forskellige egenskaber. For det første kan den vises at være størst og at være lig med 0,25 (for dikotome items) hvis opgavens sværhedsgrad er lig med elevens dygtighed, og for det andet kan den vises at blive mindre og mindre jo større forskel der er på dygtigheden og sværhedsgraden. Det svarer til at man ikke kan forvente at få noget ud af at stille en alt for let opgave til en dygtig elev. Man ved jo på forhånd at man vil få et korrekt svar. Af disse egenskaber følger det at testinformationen er størst hvis samtlige opgaver har sværhedsgrader der ligger tæt på dygtigheden, og at den aldrig kan blive større end 0,25 ganget med antallet af besvarede opgaver. Eller med andre ord: SEM kan aldrig kan blive mindre end 2 divideret med kvadratroden af antallet af besvarede opgaver.

I tabel 3.1 ses en række af de værdier man kan opnå under perfekte forhold. Tabellen viser at hvis man vil ned på en SEM på 0,30 for et bestemt profilområde, således som det oprindelig blev formuleret for nationale test, så skal der stilles mellem 40 og 50 opgaver inden for profilområdet, og disse opgaver skal have sværhedsgrader der ikke ligger alt for langt fra elevens dygtighed.

Det er disse egenskaber der er baggrunden for valget af adaptive test. Nationale test er tænkt som et redskab, der skal give ikke alt for usikre målinger for alle elever uanset. Hvis det skal opnås, er man nødt til at stille forskellige opgaver til forskellige elever. De dygtigste elever skal have vanskelige opgaver, og de mindst dygtige skal have lette opgaver. Og den teknisk bedste måde at sikre det på er ved at anvende adaptive test ${ }^{4}$.

Bemærk, at der er mest information ved opgaver som eleverne har 50 procents sandsynlighed for at svare rigtigt på. Der er således tale om opgaver som er udfordrende for eleven, men som de har en fair chance for at besvare. En adaptiv test som forsøger at optimere informationen, vil altså stille opgaver som udfordrer

\footnotetext{
${ }^{4}$ Det skal understreges at vi ikke dermed har sagt at en adaptiv test nødvendigvis er den bedste og billigste måde at teste elever på. En adaptiv test stiller nemlig en række krav til opgaverne og nødvendiggør et meget dyrt udviklingsarbejde som fjerner midler fra andre aspekter af udviklingen, fx udvikling af innovative testopgaver.
} 
eleven maksimalt. Og derfor vil eleverne i sagens natur opleve at testen er svær, og at de skal tænke over hvert eneste spørgsmål.

Den adaptive algoritme er i princippet særdeles enkel idet den består af tre trin:

1) Processen indledes med et mindre antal opgaver (i nationale test drejer det sig om tre opgaver), hvorefter det første estimat af dygtigheden beregnes.

2) Derefter vælges en enkelt opgave med en sværhedsgrad der ligger tæet på det aktuelle estimat af elevens dygtighed. Der er intet krav om at forskellige elever skal have forskellige opgaver, og heller ikke noget krav om at alle opgaver skal bruges. Kravet er kun at opgaven passer til Raschmodellen, at sværhedsgraderne er korrekte, og at der er tilstrækkelig mange opgaver til alle elever fra de mindst dygtige til de dygtigste.

3) Det aktuelle estimat opdateres, og SEM genberegnes. Hvis SEM er mindre end kravet til SEM, eller hvis tiden er udløbet, stopper algoritmen. I modsat fald vender systemet tilbage til trin 2.

Usikkerheden målt ved SEM vil være betragtelig i starten af forløbet. Det vil især være tilfældet hvis algoritmen vælger opgaver der åbenlyst er enten for lette eller for vanskelige for eleven, som det er tilfældet i nationale test. Hvis man plotter det aktuelle estimat af dygtigheden, kan der være meget store variationer i starten, og udgangspunktet kan ligge et helt andet sted end der hvor algoritmen stopper. SEM vil jo være større end 1,15 og ofte meget større efter de første tre opgaver. Det er uundgåeligt og ikke et udtryk for at der er noget galt med opgaver eller den adaptive algoritme.

Bemærk også, at estimatet genberegnes efter hver skridt på en måde der kun afhænger af hvor mange point der er scoret. Det foregående estimat indgår ikke i beregningerne. Det er altså ikke et spørgsmål om at man ser på hvordan det foregående estimat så ud, og derefter korrigerer for at tage hensyn til det nye estimat. Forløbet $(0,0,0,1)$, hvor 0 er forkert svar, og 1 er rigtigt, vil derfor give samme estimat efter fjerde trin som forløbet $(0,1,0,0)$.

Hvis forudsætningerne i form af tilpasning til Rasch-modellen er opfyldte, vil en sådan adaptiv algoritme fungere så godt som muligt. Hvis forudsætningerne ikke er opfyldt, vil den adaptive algoritme give forkerte resultater og større usikkerhed der gør forskellige testresultater usammenlignelige, både når det drejer sig om sammenligninger mellem forskellige elever, sammenligninger mellem forskellige elevpopulationer og sammenligninger mellem flere parallelle testresultater for den samme elev. Testresultaterne vil være uanvendelige og vildledende. Helt det samme vil ikke nødvendigvis være tilfældet i en lineær test hvor alle får samme opgaver, for her vil alle blive udsat for de samme systematiske fejl. Resultatet vil altså være lige forkert for alle.

Årsagen til problemerne er enkle:

1) Hvis sværhedsgraderne er forkerte, vælger systemet forkerte opgaver der ikke passer godt nok til eleverne. Det vil forøge usikkerheden (SEM).

2) Hvis sværhedsgraderne er forkerte, ville der være tale om systematiske fejl hvis det var en lineær test. Man ville ikke kunne se disse ved gentagen brug af testen for den samme elev. Men når der er tale om adaptive test, vil eleverne blive præsenteret for forskellige opgaver med hver sine fejl. Det vil få testresultater for eleven til at variere endnu mere end de skulle på grund af den almindelige usikkerhed som testresultater er behæftet med. Og det vil udsætte forskellige elever for forskellige fejl.

3) Hvis der derudover også er problemer med tilpasningen til Rasch-modellen, vil systemet bruge forkerte formler til beregning af dygtigheden hvilket vil bidrage yderligere i forhold til de fejl der blev nævnt under punkt 2 .

Der er mange rapporter om påfaldende stor variation ved sammenligning af de samme elevers resultater ved obligatoriske og frivillige nationale test (Ravn 2015c; Norling 2016). Og der er mange beskrivelser af testforløb der ved en umiddelbar betragtning ser meget mærkelige ud. Det var for at undersøge og eventuelt afkræfte en hypotese om at disse iagttagelser kan skyldes den form for modelfejl som omtales ovenfor, at analyserne i denne rapport er foretaget. 
Tabel 3.2 Uddrag af det originale datasæt

\begin{tabular}{|c|c|c|c|c|c|c|c|}
\hline elev_id & fag & profilomraade & svartidspunkt & opgavenummer & score & no_items & theta \\
\hline 100008 & Dansk/læsning 8. klasse & 1 & 02FEB2017:08:01:31.823 & 010801000301238607-1 & 0 & 1 & 0 \\
\hline 100008 & Dansk/læsning 8. klasse & 2 & 02FEB2017:08:02:09.863 & 0108020111018 & 1 & 1 & 2.5 \\
\hline
\end{tabular}

Note:

Observationerne angiver elev-id, fag, profilområde, tidspunkt for besvarelse, hvilken opgave der er besvaret, hvor mange delspørgsmål eleven havde rigtige (score), hvor mange delspørgsmål (items) opgaven bestod af, og hvad den estimerede dygtighed var efter besvarelsen af spørgsmålet (theta). For hver elev er der typisk i omegnen af 50-150 poster.

Tabel 3.3 Uddrag af det berigede datasæt

\begin{tabular}{l}
\hline Danse \\
Note:
\end{tabular}

\subsection{Karakteristika ved det anvendte datasæt}

Denne rapport er som sagt baseret på data fra nationale test i dansk, læsning i 8. klasse fra foråret 2017. Konkret består datasættet i en observation for hver elevbesvarelse af et spørgsmål (se tabel 3.2). 48.481 elever gav samlet 2.747.092 svar på 823 opgaver i nationale test i dansk, læsning i 2017.

Til brug for analyserne har vi gennemført en række beregninger af nye variable som vi har koblet til det oprindelige datasæt. Disse kan ses i tabel 3.3.

Vi har desuden udarbejdet en række omformede datasæt til brug for en Rasch-analyse (se kapitel 4) og for en undersøgelse af mønstre i besvarelser (se kapitel 5).

I tabel 3.4 ses en række oplysninger om nationale test som er beregnet ud fra datasættet.

Som det fremgår, har nogle elever formået at tømme itembanken fuldstændigt, altså svaret på alle de tilgængelige opgaver. Der er dog tale om meget få elever, og der kan være tale om at de blot har klikket sig igennem uden at svare. 134 gange har en elev besvaret 100 opgaver eller mere inden for et profilområde; i 86 af disse forløb har den samme elev besvaret mere end 100 opgaver inden for to eller tre profilområder (altså samlet mere end 200 eller 300 opgaver). Gennemsnittet af items per profilområde er 20-22 items, svarende til et samlet gennemsnit per elev på 62 items per test (der kan være flere items per opgave i profilområde 3).

I profilområde 2 er der en opgave som mere end tre femtedele af eleverne ser, og i profilområde 3 er der en opgave som mere end en tredjedel af eleverne ser. I gennemsnit ses en opgave af mellem fem til ti procent af eleverne.

En test tager i gennemsnit 53 minutter. For 50 procent tog den mere end 47 minutter, for 25 procent varede den mere end 59 minutter, og for ti procent varede den mere end 72 minutter. For de knap 500 elever (én procent) der sad længst ved testen, varede den mere end 100 minutter. 
Tabel 3.4 Centrale informationer om nationale test, 8. klassse, dansk, læsning

\begin{tabular}{|c|c|c|c|c|c|c|c|c|c|c|c|}
\hline \multirow[b]{2}{*}{ Profilområde } & \multirow[b]{2}{*}{ Opgaver } & \multirow[b]{2}{*}{ Items } & \multicolumn{2}{|c|}{ Items per elev } & \multicolumn{3}{|c|}{ Elever per item } & \multicolumn{4}{|c|}{ Tidsforbrug } \\
\hline & & & Gns. & Maks & Min & Gns. & $\operatorname{Max}$ & Opgave-gns. & Test-gns. & Test-median & Top 1\% på Test \\
\hline 1 & 308 & 308 & 19,5 & 308 & 837 & 3065 & 6629 & 0,5 & 52,9 & 47,3 & 101 \\
\hline 2 & 214 & 214 & 19,8 & 214 & 157 & 4479 & 30216 & 0,6 & & & \\
\hline 3 & 301 & 634 & 22,2 & 587 & 260 & 2806 & 18438 & 1,9 & & & \\
\hline
\end{tabular}

Note:

Varigheden af tid på opgaverne er beregnet ved at trække svartidspunktet for den foregående opgave fra denne opgaves svartidspunkt. Den første opgave i et forløb har derfor ikke nogen tid. Ved beregningen af gennemsnitlig (forkortet gns.) tid brugt på opgaverne og af samlet tid på testen er alle tider over 10 minutter betragtet som ukendte (der har sandsynligvis været holdt pause), og de indgår derfor ikke i beregningen af gennemsnit osv. 


\subsection{Indledning}

Formålet med de følgende analyser er at undersøge om de historiske sværhedsgrader som nationale tests adaptive algoritme benytter sig af, svarer til de aktuelle sværhedsgrader estimeret i data fra 2017.

For at undersøge nationale tests måleegenskaber er der brug for en sammenligning med noget der anses for korrekt. For nationale test er itemsværhedsgraderne oprindelig estimeret i forbindelse med den første gennemførsel af testen i 2010. I 2014 foretog ministeriet ifølge en artikel i Folkeskolen en fornyet Raschanalyse af itembankerne (Ravn 2015a) ${ }^{1}$. Når eleverne tager testen, anvendes de på forhånd estimerede itemsværhedsgrader til at estimere elevernes dygtigheder. Rasch-modellen bygger på en empirisk underbygget hypotese om at elever der tager de samme opgaver, vil opleve dem som tilsvarende svære. Om dette er tilfældet kan testes ved at genestimere opgavernes sværhedsgrader og elevernes dygtigheder. Det er en sådan analyse denne rapport præsenterer.

Udgangspunktet for sammenligningerne er at estimaterne af sværhedsgraderne i 2017 er et udtryk for opgavernes sande sværhedsgrader for de elever der tog testen i 2017. Der er naturligvis en vis usikkerhed forbundet med estimaterne, men datamaterialet er som omtalt i kapitel 3, særdeles omfattende således at usikkerheden af estimaterne er begrænset. Hvis nationale tests sværhedsgrader passer til virkeligheden som den ser ud i 2017, skal forskellen på nationale tests sværhedsgrader og 2017-estimaterne være meget begrænsede.

Hvis der er god overensstemmelse mellem de to sæt sværhedsgrader, skal der også være en tilsvarende god overensstemmelse mellem estimaterne af færdigheden og de beregnede SEM-mål for målingernes usikkerhed. Hvis de to sæt sværhedsgrader er forskellige, vil målingerne af færdighederne også være forskellige, og usikkerheden vil være større i de sande 2017-estimater af færdighederne end i de forkerte nationale testestimater fordi den adaptive rutine vælger forkerte opgaver der bidrager med mindre information end hvis systemet havde valgt nye opgaver baseret på de korrekte sværhedsgrader. Disse forhold vil blive beskrevet hvis sammenligningen mellem de to sæt sværhedsgrader falder negativt ud.

\subsection{Statistiske metoder}

Den Rasch-model der anvendes til analyserne af data fra 2017, er den samme som den der blev anvendt i forbindelse med den oprindelige afprøvning af nationale test. Forudsætningerne for analysen af data fra 2017 er derfor de samme som de forudsætningerne, der lå bag den oprindelige afprøvning af nationale test, og der er ikke tilføjet nye og mere restriktive forudsætninger i 2017-analysen. Det er med andre ord muligt at afprøve kvaliteten af nationale test i 2017 på nationale tests egne præmisser.

Med hensyn til de statistiske metoder der anvendes, er der små forskelle på analyserne i forbindelse

\footnotetext{
${ }^{1} \mathrm{Vi}$ har ikke været i stand til at finde dokumentation fra Undervisningsministeriet der beskriver denne reestimation af itemsværhedsgraderne.
} 
med afprøvningen og analyserne af data fra 2017 fordi vi har anvendt metoder til at estimere item- og personparametre der er lidt bedre end dem der blev anvendt i forbindelse med de tidligere analyser. Da der i alle tilfælde er tale om analyser af meget store datamaterialer vil forskellen på de forskellige metoder til at estimere Rasch-modellens parametre være uden praktisk betydning. Den usikkerhed som alle former for statistiske beregninger er behæftet med, vil for begge metoder være meget begrænset på grund af datamaterialernes størrelser. Vi betragter stadig de metoder man tidligere benyttede, som gode nok, og man kan uden problemer tillade sig at sammenligne estimaterne fra 2010 og 2014 med estimaterne fra 2017. Hvis der er store forskelle, er det fordi sværhedsgraderne i 2017 afviger fra de tidlige sværhedsgrader. Det vil ikke være en konsekvens af at der bruges forskellige metoder til at estimere dem eller et resultat af den statistiske usikkerhed som estimaterne er behæftet med.

\subsubsection{Beregning af tal for sværhedsgrader og dygtighed}

Rasch-modellens item- og personparametre der er udtryk for henholdsvis opgavernes sværhedsgrader og elevernes dygtighed, estimeres for hvert profilområde for sig.

Estimation af parametre i Rasch-modellen foregår i to trin, hvor det første trin estimerer opgavernes sværhedsgrader, og hvor det andet trin bruger disse estimater til at beregne estimater af dygtigheden for de enkelte elever. De nationale tests sværhedsgrader er estimeret ved hjælp af såkaldte pairwise estimates (Zwinderman 1995) der har den fordel at estimaterne ikke stiller krav om at personerne er fordelt på en bestemt måde. Da pairwise estimates ikke udnytter det indsamlede datamateriale fuldt ud, er disse estimater behæftet med en lidt større usikkerhed end andre estimater af Rasch-modellens item-parametre.

Opgavernes sværhedsgrader i 2017 estimeres vha. såkaldte marginal estimates (Boch og Aitken 1981). Disse estimater stiller ingen krav til dygtigheden for de enkelte elever, men det antages at fordelingen af dygtigheden er tilnærmelsesvis normalfordelt, og middelværdien og spredningen i denne fordeling estimeres samtidig med at sværhedsgraderne estimeres. De marginale estimater er naturligvis følsomme over for meget store afvigelser fra antagelse om normalfordelingen, men estimaterne udnytter til gengæld data fuldt ud og vil derfor være mindre usikre end andre estimater af Rasch modellens sværhedsgrader. Som det vil fremgå af det følgende, er forudsætningerne for anvendelsen af marginale estimater opfyldt.

I forbindelse med analysen af data fra 2017 beregnes tal for dygtigheden ved hjælp af såkaldte Weighted Maximum Likelihood (WML) estimater, mens nationale test beregner dygtigheden ved hjælp af almindelige Maximum likelihood-metoder (ML-metoder). Der henvises til Kreiner og Christensen (2013) for en nærmere forklaring af forskellen på de to estimater. Alle estimater af dygtigheden i Rasch-modellen er præget af en vis grad af systematisk bias for elever der har besvaret mange opgaver der enten er for lette for eleven eller for vanskelige for eleven. Valget af WML-estimater i denne analyse skyldes at de er præget af mindre systematisk fejl end andre estimater. Brugen af ML-estimater i nationale test skyldes at adaptive test kontrollerer at der hverken er for mange lette eller for mange vanskelige opgaver for eleverne, således at det kan forudses at nationale tests estimater af dygtigheden ikke vil have de samme problemer med systematiske fejl som ML-estimater kan have i almindelige test. I forbindelse med analyserne af enkelte testforløb i kapitel 5 og bilag B er der beregnet både WML- og ML-estimater for at undersøge om forventningerne til ML-estimaterne er opfyldt. Det viser sig at være tilfældet.

Da estimeringen af dygtigheden udnytter værdierne af sværhedsgraderne, følger det at dygtigheden altid bestemmes relativt til opgavernes sværhedsgrader, og at tallene for dygtigheden ikke kan betragtes som absolutte mål for dygtigheden. Forskellen på dygtighederne for to elever fortæller hvor meget dygtigere den ene er i forhold til den anden, men tallene i sig selv siger intet om hvorvidt den dygtigste i faglig forstand er dygtig og om den mindst dygtige er udygtig.

Udover det fortæller teorien for Rasch-modeller at tallene for sværhedsgraderne og tallene for dygtigheden kan placeres på en og samme intervalskala der i Rasch-modellens terminologi omtales som en logit-skala ${ }^{2}$. Det vil føre for vidt her at forklare hvorfor man anvender denne terminologi, og det er i øvrigt uden praktisk

\footnotetext{
${ }^{2}$ Logits er tal der fremkommer ved følgende transformation af sandsynligheder målt på skalaer fra 0 til 1 . Hvis p er lig med sandsynligheden, er den tilsvarende logit-værdi lig med den naturlige logaritme af p/(1-p).
} 
Tabel 4.1 Centrale parametre fra analysen af data fra nationale test.

\begin{tabular}{llllll}
\hline Analyse & Antal Items & Elever & Reliabilitet & Varians & Antal Parametre \\
\hline Profilområde 1 & 308 & 48481 & 0,796 & 1,031 & 309 \\
Profilområde 2 & 214 & 48481 & 0,778 & 0,904 & 215 \\
Profilområde 3 & 301 & 48481 & 0,779 & 0,859 & 635 \\
\hline \multicolumn{7}{l}{ Reliabilitet: Reliabilitetsmål baseret på TAM-pakkens Estimated A Posteriori- } \\
estimat af elevernes dygtigheder. \\
${ }^{2}$ Varians: Varians af elevparametrene. \\
${ }^{3}$ Antal parametre: Antal parametre som estimationen har udregnet (items plus \\
steps plus gennemsnit).
\end{tabular}

betydning. I denne sammenhæng er det tilstrækkeligt at gøre opmærksom på at denne rapport bruger samme terminologi fordi den vil være genkendelig for eksperter med forstand på Rasch-analyser.

\subsubsection{En, to eller tre latente dimensioner}

Nationale test antager at de tre profilområder måler tre kvalitativt - men naturligvis korrelerede - forskellige latente dimensioner. Tre forskellige færdigheder. Konsekvensen af denne antagelse er at der bliver relativt lidt tid til hvert profilområde og derfor forholdsvis få opgaver og stor usikkerhed per profilområde. Valget af netop tre profilområder i hvert eneste fag har - så vidt vi ved - aldrig været fagligt motiveret, og minder mere om en administrativ beslutning som er truffet for at gøre udviklingen af nationale test så enkel som mulig.

Da beslutningen har konsekvenser for sikkerheden, og da nationale test har været kritiseret for at give for usikre resultater, har vi i denne rapport inkluderet ekstra analyser der kan belyse om nationale tests profilområder måler en, to eller tre forskellige dimensioner. Denne analyse er foretaget ved hjælp af marginale metoder til analyse af multivariate Rasch-modeller (Adams og Wu 2007) der antager at de forskellige færdigheder der ligger bag de tre profilområder, fordeler sig som multivariate normalfordelinger, og som estimerer korrelationer og kovarianser mellem profilområderne samtidig med estimationen af middelværdier og varianser.

Alle analyser i dette kapitel er foretaget ved hjælp af R-pakken TAM. Der henvises til dokumentationen for dette program (Robitzsch, Kiefer, og Wu 2019) og til dokumentationen for ConQuest (Wu m.fl. 2007) som TAM bygger på, samt Adams og Wilson (1996) og Adams, Wilson, og Wang (1997) for yderligere oplysninger om multivariate Rasch-modeller og itemanalyse ved hjælp af marginale metoder. Scriptet der er anvendt, kan rekvireres hos forfatterne (tillige med alle de øvrige scripts der er udviklet til denne rapport).

Analysen er foretaget på datasættet bestående af alle elevbesvarelser af nationale test i dansk, læsning for 8. klasse i 2017. Vi kalder i det følgende denne analyse for 2017-analysen, mens analysen som nationale test viser på, kaldes DNT-analysen. Til brug for denne analyse er datasættet omkodet så der er en række for hver af de 48.481 elever og en kolonne for hver af de 823 opgaver. Derved er hver elevs score (rigtigt/forkert) registreret for hver opgave. Centrale parametre fra analysen er gengivet i tabel 4.1 


\subsection{Sammenligning af sværhedsgrader og elevdygtigheder i 2017-analysen og nationale tests analyse}

\subsubsection{Sammenligning af sværhedsgrader}

Bilag C indeholder en tabel over sværhedsgraderne ifølge DNT og sværhedsgraderne ifølge analysen af 2017materialet.

Figur 4.1 viser sammenhængen mellem sværhedsgraderne ifølge 2017-analysen og DNT. Det fremgår tydeligt af figuren at DNT- og 2017-analysen ikke er helt enige om vurderingen af sværhedsgraden af de enkelte items, men punkterne fordeler sig om den sorte identitetslinje for alle tre profilområder. Figurerne illustrer de høje korrelationer ${ }^{3}$ mellem de to sæt sværhedsgrader hvilket betyder at DNT- og 2017-analysen er nogenlunde enige om hvilke opgaver der er mere eller mindre vanskelige.

For at give et indtryk af Rasch-modellens probabilistiske natur, og dermed af hvordan man må acceptere forskelle i estimater på tværs af analyser, har vi gennemført en analyse af data hvor vi har delt eleverne op i to halvdele med henholdsvis 24.240 og 24.241 tilfældigt valgte elever. For hver af disse grupper har vi kørt den samme Rasch-analyse som for hele gruppen af elever, og derefter har vi sammenlignet estimaterne af itemsværhedsgrader i de to analyser. Resultatet er gengivet grafisk (for alle tre profilområder i samme diagram) i det nederste højre diagram af figur 4.1.

\footnotetext{
${ }^{3}$ De er henholdsvis $0,91,0,87$ og 0,9 for de tre profilområder
} 

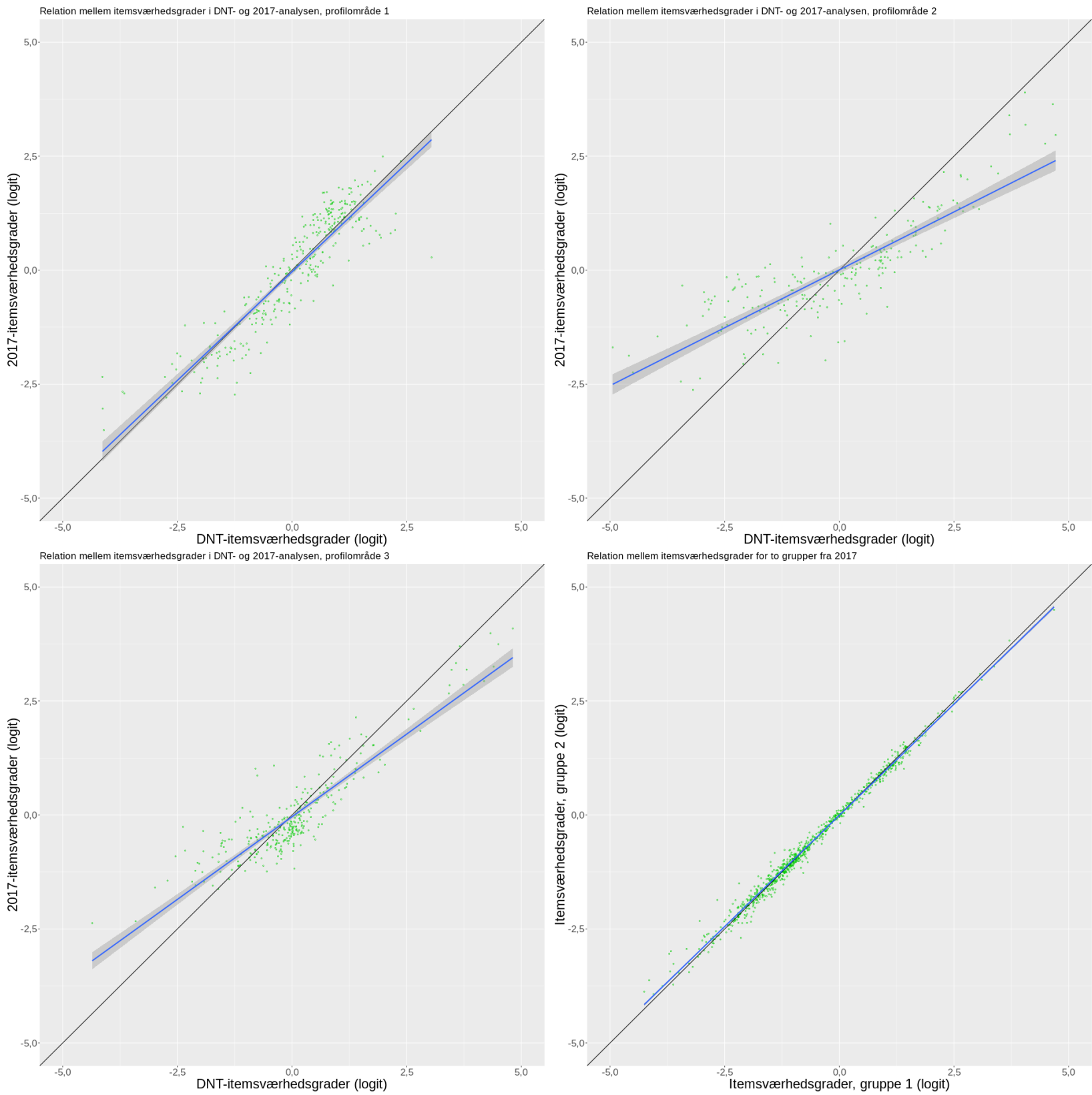

Figur 4.1 Sammenligning af 2017-analysens og DNT's estimat af sværhedsgrader for de tre profilområder. Der er indtegnet en sort identitetslinje og en blå linje med konfidensinterval der viser regression af 2017værdier på DNT-værdier. Det nederste højre diagram viser estimater af sværhedsgrader (alle profilområder) for to tilfældigt valgte grupper elever fra 2017. 

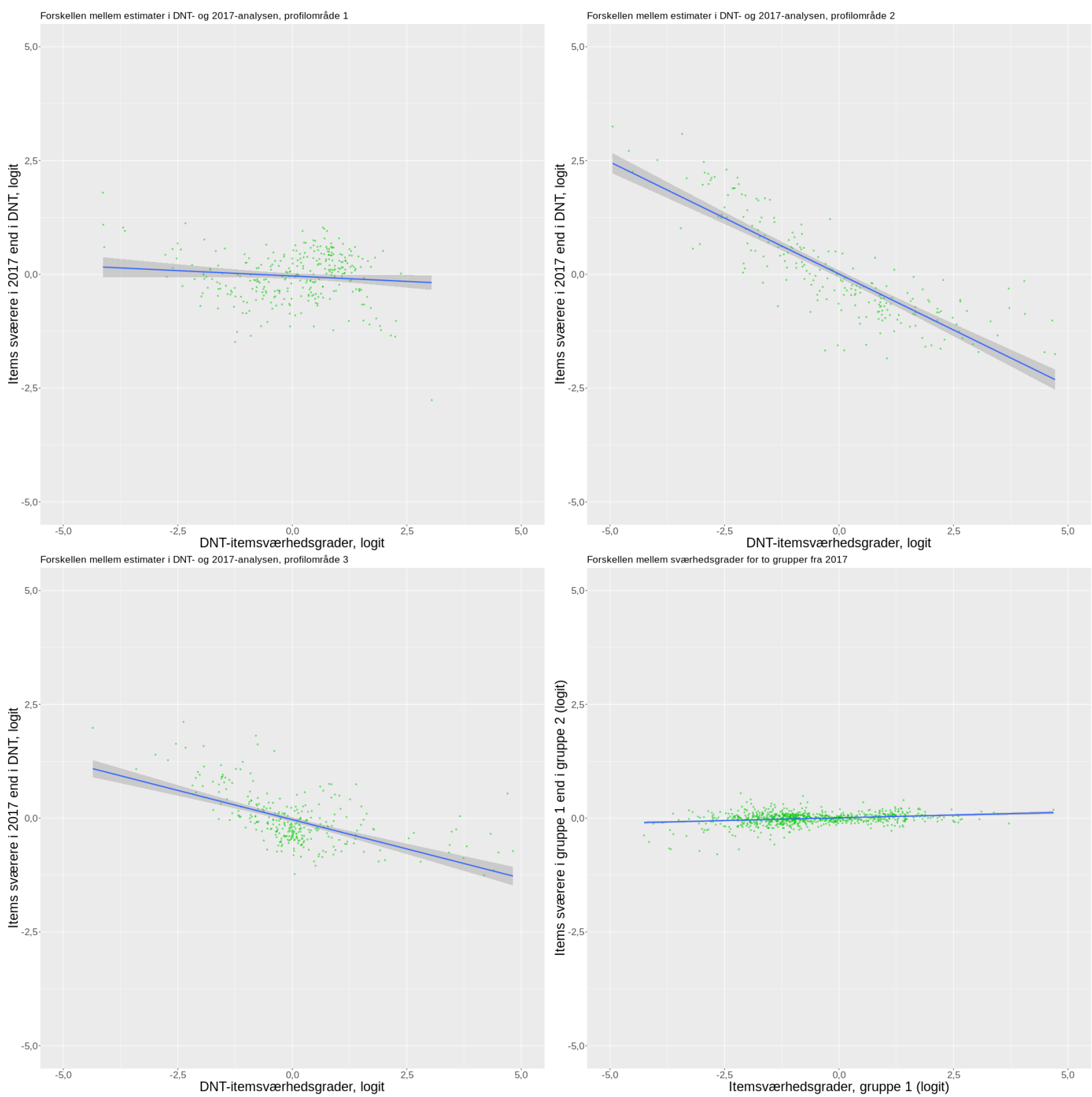

Figur 4.2 Forskellen mellem 2017-analysens og DNT's estimat af sværhedsgrader for de tre profilområder i forhold til sværhedsgraden i DNT. Det nederste højre diagram viser forskellene i sværhedsgrader (alle profilområder) estimeret for to tilfældigt valgte grupper elever fra 2017.

I figur 4.2 er forskellen mellem DNT's og 2017-analysens estimat af itemsværhedsgrader plottet som funktioner af DNT-sværhedsgraderne. De faldende regressionslinjer viser at det for profilområde 2 og 3 gælder at de opgaver der var svære i DNT's estimation, generelt er blevet lettere, mens de opgaver der var lette, er blevet sværere. Sagt på en anden måde, er spredningen af opgavernes sværhedsgrader i profilområde 2 og 3 blevet mindre i $2017^{4}$. Særligt for profilområde 2 er forskellen dramatisk. Nederste højre diagram i figur 4.2 viser til sammenligning forskellene i analysen af to grupper elever fra 2017 som omtalt ovenfor.

\footnotetext{
${ }^{4}$ I første udgave af rapporten fremstod det som om disse forskelle også kendetegnede profilområde 1, men som det fremgår af figuren $\varnothing$ verst til venstre, er det ikke tilfældet ifølge de korrekte itemsværhedsgrader
} 
Histogrammerne i figur 4.3 viser fordelingen af den absolutte forskel på de to estimater af sværhedsgraden for de tre profilområder. Den gennemsnitlige absolutte forskel er henholdsvis 0,42, 0,91 og 0,44 for de tre profilområder hvilket på logitskalaen er udtryk for betydelige forskelle.
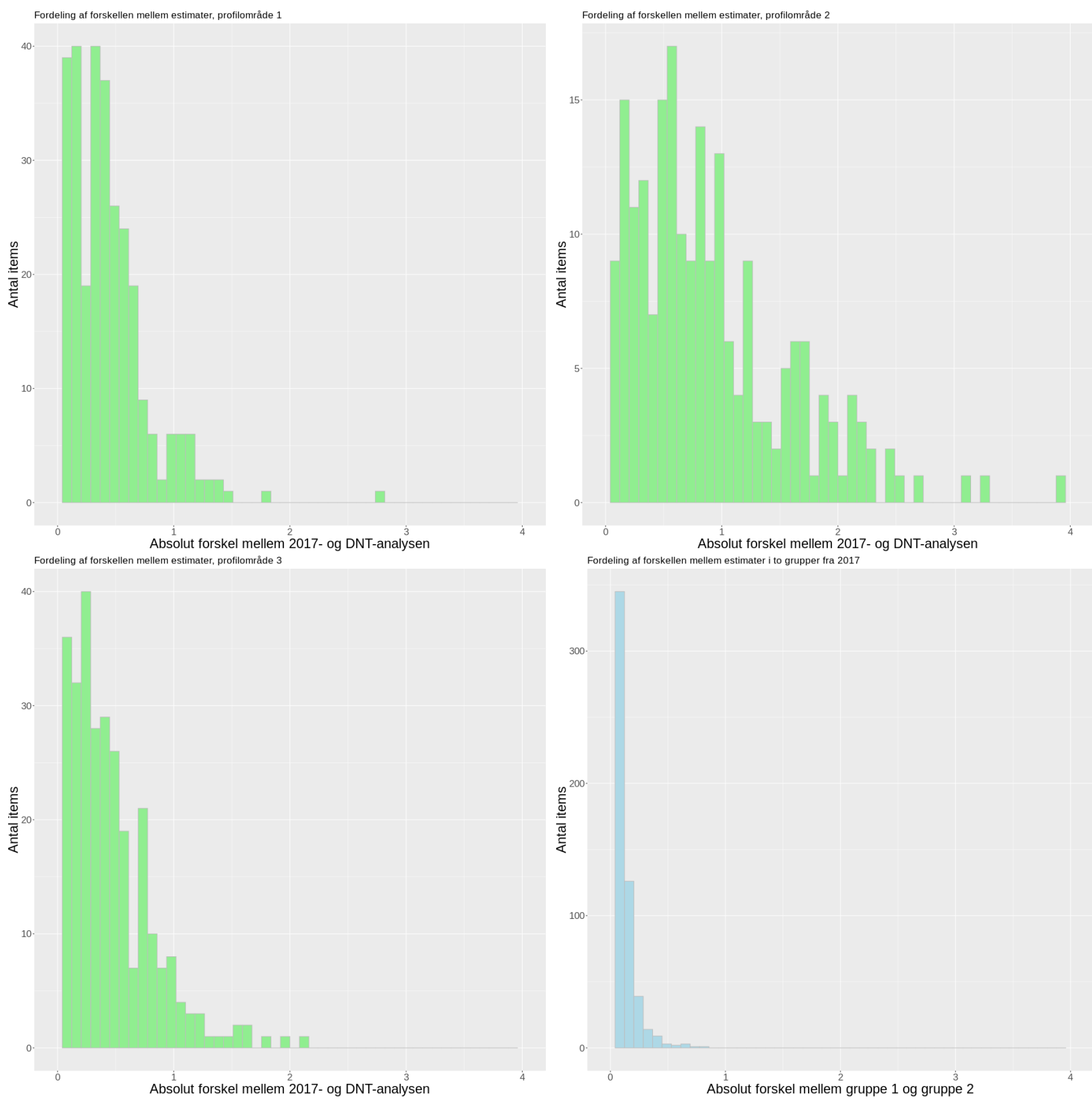

Figur 4.3 Fordelingen af forskellen mellem 2017-analysens og DNT's estimat af sværhedsgrader for de tre profilområder, samt nederst til højre en sammenligning af estimat af sværhedsgrader (alle profilområder) målt på to grupper af elever fra 2017.

I tabel 4.2 ses antallet af items der ligger inden for intervaller af forskelle mellem DNT- og 2017-analysen.

I figur 4.4 ses de samme forskelle illustreret ved at angive de estimerede itemsværhedsgrader ifølge henholdsvis DNT- og 2017-analysen på hver sin linje, og forbinde det enkelte items estimat med en linje. Hvis estimatet 
Tabel 4.2 Fordeling af absolut forskel i estimerede sværhedsgrader mellem DNT- og 2017-analyserne.

\begin{tabular}{lrrr}
\hline Interval & Profilområde 1 & Profilområde 2 & Profilområde 3 \\
\hline $0-0,5$ & 212 & 65 & 202 \\
$0,5-1$ & 73 & 75 & 78 \\
$1-1,5$ & 21 & 32 & 14 \\
$1,5-2$ & 1 & 25 & 6 \\
$2-2,5$ & 1 & 12 & 1 \\
$2,5-3$ & & 2 & \\
$3-3,5$ & & 2 & \\
$3,5-4$ & & 1 & \\
\hline
\end{tabular}

Note:

Forskelle er medtaget i det interval hvis nedre grænse de er større end, og hvis øvre grænse de er mindre end eller lig med.

er nøjagtig det samme, vil linjen være lodret, og hvis der er forskel, vil linjen være skrå. Jo større hældning, des større er uenigheden om estimatet mellem de to analyser ${ }^{5}$.

Det nederste højre diagram af figurerne 4.3 og 4.4 gengiver forskellene i itemsværhedsgrader i analysen af to grupper fra 2017. Som det fremgår, er der for nogle items uenighed om hvor svære items der overstiger 0,5 logit, er. Helt præcist drejer det sig om 8 items svarende til 1 procent. 4,4 procent af items estimeres mellem 0,25 og 0,5 forskelligt i de to analyser. Som det fremgår af disse tal såvel som af figurerne, er forskellene mellem 2017-analysen og DNT langt mere omfattende.

\footnotetext{
${ }^{5}$ Ideen til stregfigurerne er udviklet af Peter Allerup.
} 

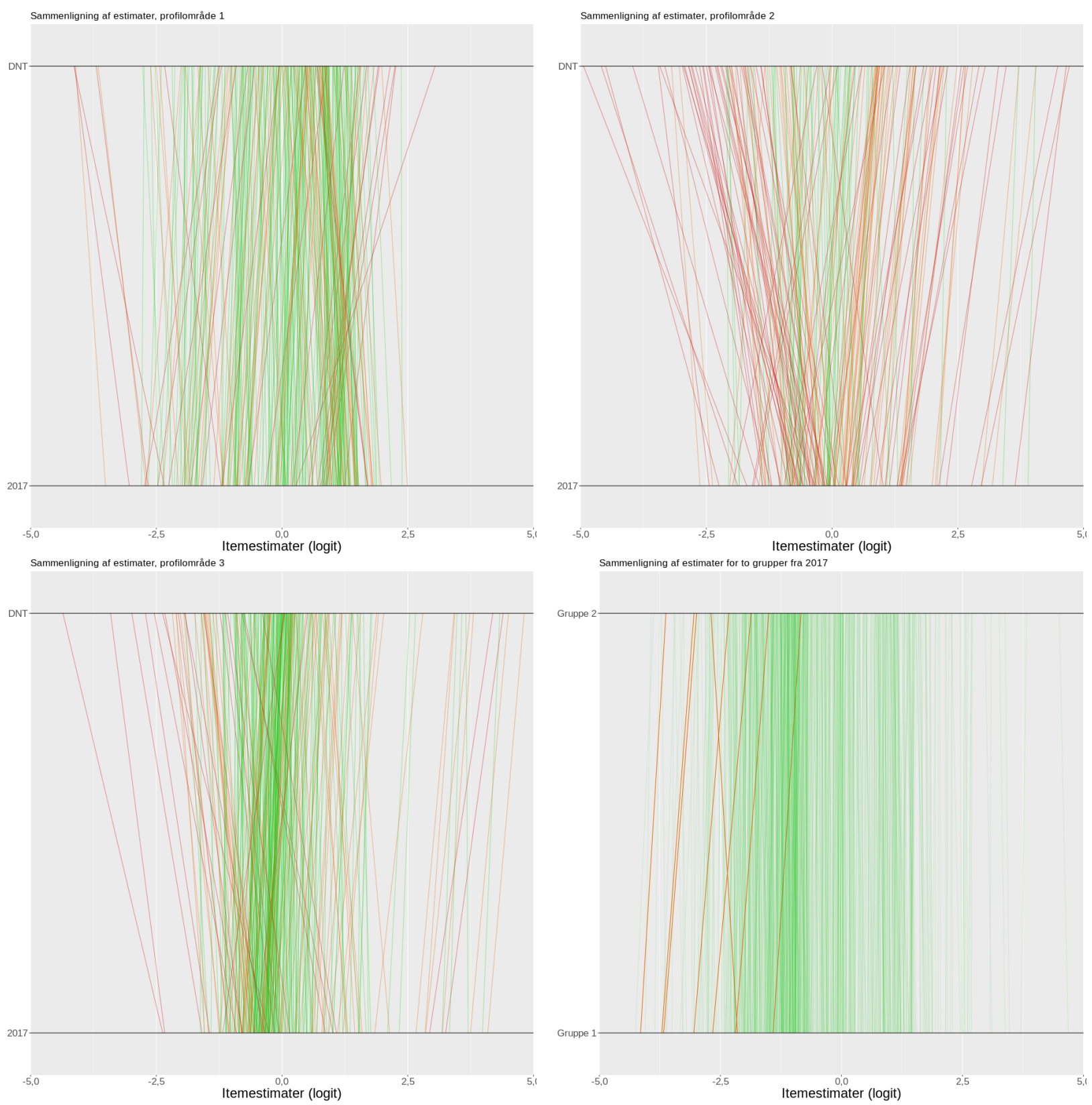

Figur 4.4 Sammenligning af 2017-analysens og DNT's estimat af sværhedsgrader for de tre profilområder, samt nederst til højre en sammenligning af estimat af sværhedsgrader (alle profilområder) målt på to grupper af elever fra 2017. Der er grønne streger mellem estimater hvor forskellen er mindre end 0,5 logit, orange streger hvor forskellen er mellem 0,5 og 1 logit, og røde streger hvor forskellen er over 1 logit.

\subsubsection{Betydning af at opgaver med forkerte sværhedsgrader vælges}

Tabel 4.3 viser betydningen af at sværhedsgraderne i 2017 afviger fra de sværhedsgrader som nationale testalgoritmen anvender. Hvis nationale test-algoritmen vælger en opgave der ligger tæet på elevens dygtighed, vil chancerne for et korrekt svar være ca. 50 procent. Hvis opgavens sværhedsgrad målt på Rasch-modellens logitskala afviger med et point i 2017 i forhold til det nationale test-algoritmen har estimeret, vil chancerne for et korrekt svar være ca. 73 procent hvis opgaven er lettere, men kun 27 procent hvis opgaven er vanskeligere. 
Tabel 4.3 Oversigt over betydning af forskellen på sværhedsgraderne i DNT og 2017 for opgaver, der ifølge DNT skulle svare til elevens dygtighed.

\begin{tabular}{ccccc}
\hline & \multicolumn{3}{c}{ Sandsynlighed for korrekt svar } & \\
\cline { 2 - 3 } Absolut forskel & Lettere end antaget & Korrekt sværhedsgrad & Vanskeligere end antaget & Andel information ifht. optimalt \\
\hline 0,25 & 0,56 & 0,5 & 0,44 & $98 \%$ \\
0,50 & 0,62 & 0,5 & 0,38 & $94 \%$ \\
1,00 & 0,73 & 0,5 & 0,27 & $79 \%$ \\
1,50 & 0,82 & 0,5 & 0,18 & $42 \%$ \\
2,00 & 0,88 & 0,5 & 0,12 & $28 \%$ \\
2,50 & 0,92 & 0,5 & 0,08 & $18 \%$ \\
3,00 & 0,95 & 0,5 & 0,05 & $11 \%$ \\
3,50 & 0,97 & 0,5 & 0,03 & $\%$ \\
\hline
\end{tabular}

${ }^{1}$ Absolut forskel er forskellen mellem elevens dygtighed og opgavens sværhedsgrad uden fortegn.

2 I søjlen 'Lettere end antaget' angives hvor stor sandsynligheden er for at eleven svarer rigtigt hvis opgaven er så meget lettere i 2017 som det er angivet i søjlen 'Absolut forskel'.

${ }^{3}$ I søjlen 'Korrekt sværhedsgrad' angives hvor stor sandsynligheden er for korrekt svar når opgaven har den forventede sværhedsgrad.

${ }^{4}$ I søjlen 'Sværere end antaget' angives hvor stor sandsynligheden er for et korrekt svar når opgaven er så meget sværere i 2017 som angivet i 'Absolut forskel'.

${ }^{5}$ I den sidste søjle angives hvor meget information der opnås når forskellen er så stor som angivet i 'Absolut forskel', sammenlignet med hvad den ville være hvis sværhedsgraden passede til elevens dygtighed.

Hvis forskellen er to point på logitskalaen, er der 88 procents chance for en lettere opgave og kun 12 procent for en vanskeligere opgave.

Hvis opgaven er lettere end DNT forventer, vil det naturligvis ikke være et problem for eleven, men det vil forringe sikkerheden af målingerne fordi et svar på en let opgave ikke bidrager med megen information der kan hjælpe til at præcisere vurderingen af målingen.

Det samme er tilfældet hvis opgaven er for vanskelig, men udover det vil eleven måske opleve testsituationen som ubehagelig fordi han skal løse en opgave der klart ligger ud over det han kan magte. Det forhold at den adaptive algoritme kan vælge opgaver der er vanskeligere end forventet og måske langt over det som eleven kan klare, kan måske forklare nogle af de dårlige oplevelser som lærere og forældre har rapporteret om i pressen, og som er beskrevet i undersøgelser (Bundsgaard og Puck 2016; Wandall, Nørrelund, og Nielsen 2018).

Den information som svaret på en opgave bidrager med, og som normalt omtales som item-information, kan kvantificeres. Det er derfor også muligt at måle præcis hvor megen item-information der mistes, hvis nationale test-algoritmen udvælger en opgave der afviger fra elevens dygtighed. Den sidste kolonne i tabel 4.3 giver en oversigt over disse forhold. Bemærk at forskelle på 0,5 kun fører til en beskeden reduktion af item-informationen. Denne iagttagelse har betydning for den adaptive algoritme som i sagens natur sjældent kan finde en opgave med en sværhedsgrad der passer præcist til elevens dygtighed. Hvis en udvalgt opgave rammer 0,25 logit ved siden af målt på logitskalaen, vil item-informationen kun være to procent mindre, end hvis algoritmen havde valgt en opgave med præcis den samme sværhedsgrad som elevens dygtighed.

\subsection{Fordeling af elevdygtighed}

De følgende figurer beskriver fordelingen af dygtigheden sådan som DNT ser den, og sådan som den i virkeligheden er ifølge 2017 -analysen ${ }^{6}$.

\footnotetext{
${ }^{6}$ Af denne figur fremgår det at antagelsen fra MCML-analysen om normalfordelte elevdygtigheder bekræftes af 2017-analysen og anvendelse af marginale estimater er derfor velbegrundet.
} 
I figur 4.5 er fordelingen af elevdygtigheder ifølge 2017- og DNT-analyserne gengivet som histogrammer der er lagt ind over hinanden således at man kan se hvor de adskiller sig. DNT's elevdygtigheder er hentet fra datasættet som den estimerede dygtighed efter det sidste item, eleven har besvaret.
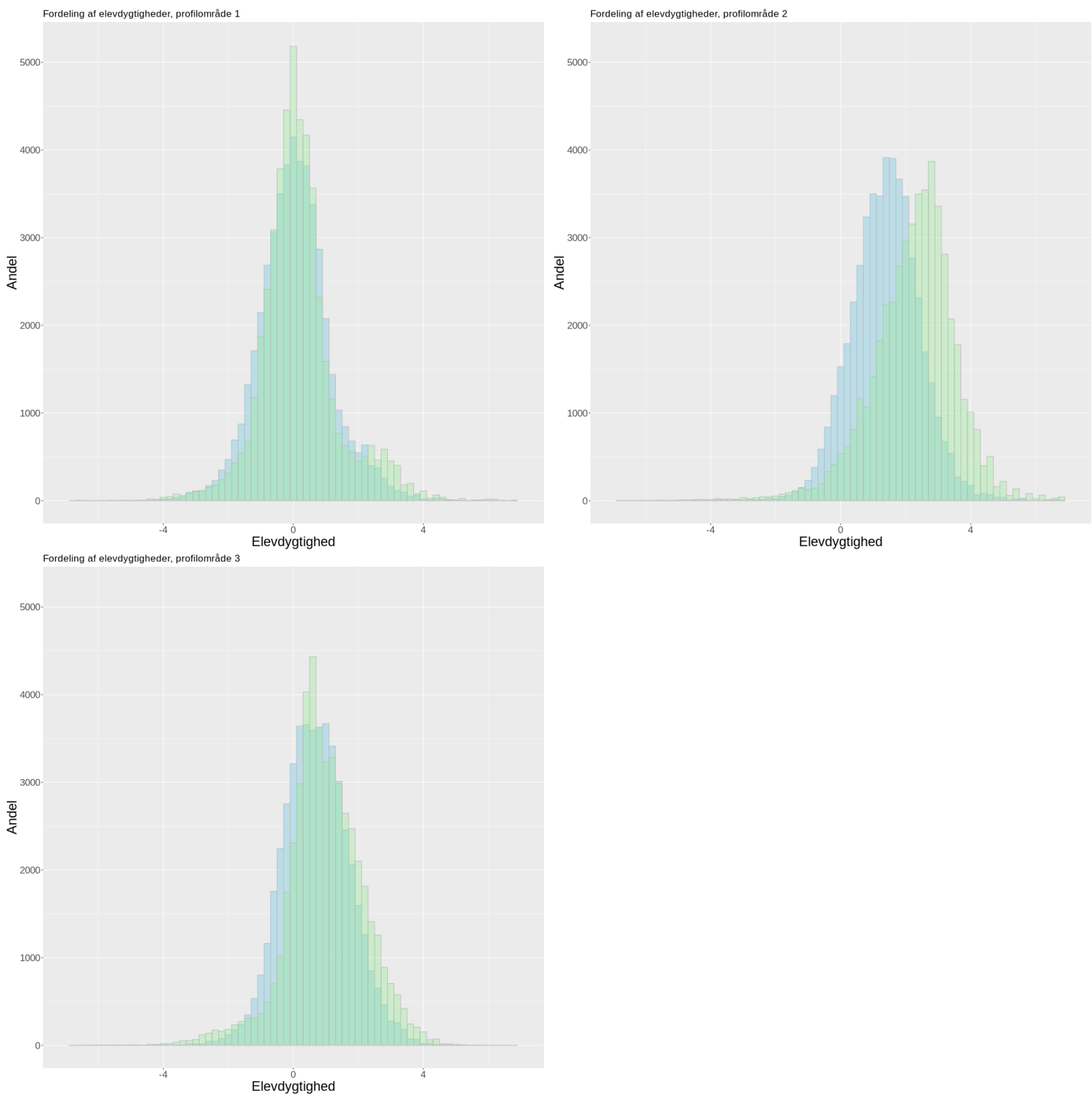

Figur 4.5 Fordelingen af elevernes dygtigheder. Den blå nuance angiver 2017-analysens estimat, og den grønne nuance angiver DNT's estimat.

Begge fordelinger har ved et umiddelbart blik de karakteristiske træk ved en normalfordeling i form af to haler for de dygtige og de mindst dygtige elever og en stor krop hvor flertallet af eleverne befinder sig.

Men det kan også se ud som om fordelingerne i DNT's estimerede elevdygtigheder er præget af en vis skævhed. Således er der tilsyneladende flere under end over middel dygtige elever i profilområde 2, mens det kan se ud som om der er flere over middel end under middel dygtige elever i profilområderne 1 og 3. 
Tabel 4.4 Centrale parametre for beskrivelse af tilnærmelsen til normalfordelingen for 2017-analysens og DNT's estimerede elevdygtigheder.

\begin{tabular}{|c|c|c|c|c|c|c|c|c|c|c|}
\hline \multirow[b]{2}{*}{ Dimension } & \multicolumn{2}{|c|}{ Middelværdi } & \multicolumn{2}{|c|}{ Median } & \multicolumn{2}{|c|}{ Standardafvigelse } & \multicolumn{2}{|c|}{ Kurtosis } & \multicolumn{2}{|c|}{ Skævhed } \\
\hline & 2017 & DNT & 2017 & DNT & 2017 & DNT & 2017 & DNT & 2017 & DNT \\
\hline Profilområde 1 & 0,05 & 0,18 & 0,03 & 0,07 & 1,1 & 1,2 & 1,46 & 2,6 & 0,17 & 0,53 \\
\hline Profilområde 2 & 1,38 & 2,26 & 1,40 & 2,39 & 1,1 & 1,3 & 1,53 & 3,2 & $-0,08$ & $-0,73$ \\
\hline Profilområde 3 & 0,70 & 0,97 & 0,68 & 0,92 & 1,0 & 1,2 & 0,82 & 1,9 & $-0,06$ & $-0,42$ \\
\hline
\end{tabular}

Dette underbygges af parametrene i tabel 4.4 som indeholder de centrale parametre til beskrivelse af de to fordelingers overensstemmelse med normalfordelingen.

Som det fremgår er Kurtosis for både 2017- og DNT-analysen højere end 0 som er værdien for en ren normalfordeling. Dette er udtryk for at der findes en del outliers i fordelingerne hvilket kan forventes idet nogle elever vil svare ukoncentreret, blive stoppet før tid, osv. Men forskellen på 2017- og DNT-fordelingen er væsentlig, og DNT identificerer således væsentligt flere outliers end 2017-analysen.

Forskellen i skævhed i 2017- og DNT-fordelingerne er endnu mere iøjnefaldende. For 2017-analysen er skævheden tæt på 0 for alle tre dimensioner, mens den for DNT er høj, særligt for profilområde 2. Dette underbygger de iagttagelser der kunne gøres ved blot at betragte histogrammerne.

\subsection{Estimater på dygtigheder i 2017-analysen og i DNT's analyse}

Figur 4.6 viser en sammenligning af estimatet af dygtigheden for de enkelte elever ifølge 2017-analysen og DNT. 

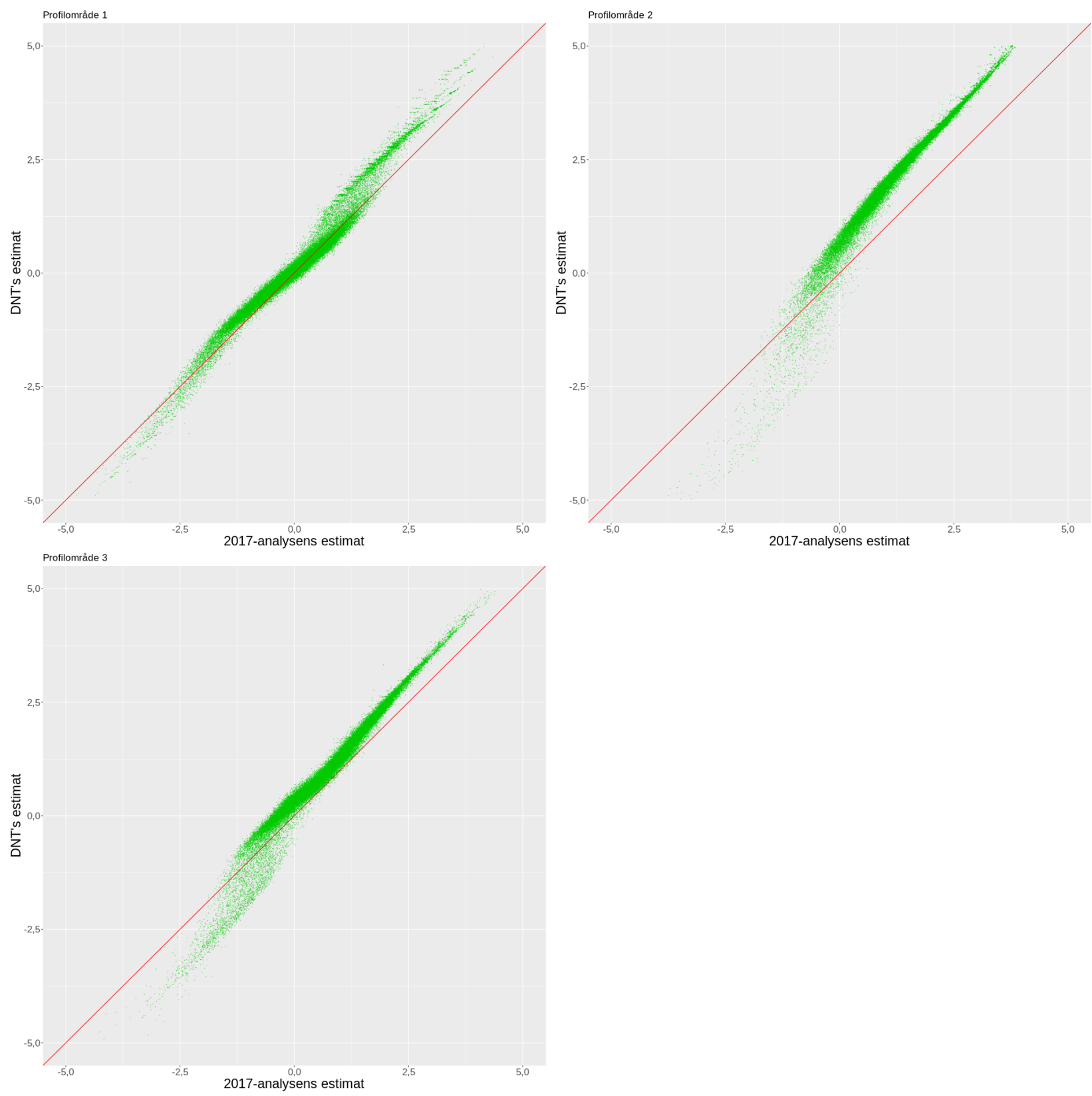

Figur 4.6 Sammenligning af 2017-analysens og DNT's estimat af elevdygtigheder for de tre profilområder. Dygtighederne ifølge 2017-analysen findes på x-aksen og dygtighederne ifølge DNT's analyse findes på yaksen. De grønner prikker symboliserer hver for sig én elev. Den røde streg er en identitetslinje der viser hvor målingerne er ens i de to analyser.

Som det fremgår er de to målinger af dygtigheder positivt korreleret, men de bekymrende tendenser som blev identificeret i undersøgelsen af fordelingen af elevdygtighederne (afsnit 4.4), bliver meget tydelige i disse figurer. Det gælder for alle tre profilområder at de mindst dygtige elever vurderes for lavt af DNT (grønne prikker ligger under identitetslinjen i den nederste del af dygtighedsskalaen), og de dygtigste vurderes for højt (grønne prikker over identitetslinjen). Særligt for profilområde 2 er det en meget markant tendens, men også profilområde 3 er den betydningsfuld. Nationale test producerer således systematisk forkerte estimater af elevernes dygtighed. 


\subsection{Standard Error of Measurement (SEM)}

Standard Error of Measurement (SEM) er et udtryk for hvor sikker man kan være på den enkelte elevs estimerede resultat. Det der gør en adaptiv test eftertragtelsesværdig, er at den ideelt set stiller opgaver på elevens dygtighedsniveau og derved får meget information ud fra elevenes svar, således at alle elevers resultat måles med den samme sikkerhed. Som tidligere beskrevet (i afsnit 3.4) anvendes SEM af den adaptive algoritme som kriterium for hvornår estimatet på elevens dygtighed er tilstrækkeligt præcist, og testen derfor kan afsluttes.

I et af de dokumenter der lå til grund for udviklingen af nationale test, Svend Kreiners notat om adaptive test (Kreiner 2007), omtales en SEM på 0,16 som ønskværdig og realistisk i en perfekt adaptiv test. SEM afhænger af antallet af opgaver der stilles. I udviklingsprocessen blev det klart at det ikke var realistisk med et antal opgaver som kunne få SEM ned på 0,16. I stedet blev kravet til nationale tests målinger at de skulle have en SEM på 0,3 hvilket generelt betragtes som en god sikkerhed som vil resultere i en acceptabel reliabilitet på 0,9 , hvis variansen af tallene for dygtigheden er tæt på 1 .

Det lader til at det i de første tre-fire år af testens levetid var forventningen hos ministeriet at der faktisk var tale om en SEM på 0,3 (Wandall 2010). Men i 2014 blev det klart for ministeriet at algoritmen ikke var programmeret til at stoppe ved en SEM på 0,3, men allerede ved en SEM på 0,55 (Ravn 2014). Ifølge Undervisningsministeriets oplysninger betragter den adaptive algoritme således forløbet i et profilområde som afsluttet når SEM når under 0,55 (Styrelsen for It og Læring 2015). Derefter giver den adaptive algoritme kun opgaver i de profilområder der ikke er nået under 0,55. Når SEM er nået under 0,55 i alle tre profilområder, begynder algoritmen at give opgaver inden for alle tre områder igen, og læreren får med en grøn mærkat besked om at testen kan afsluttes.

I figuren 4.7 vises SEM som den er beregnet i 2017-analyserne, som funktion af elevdygtigheden (theta) i de tre profilområder. 


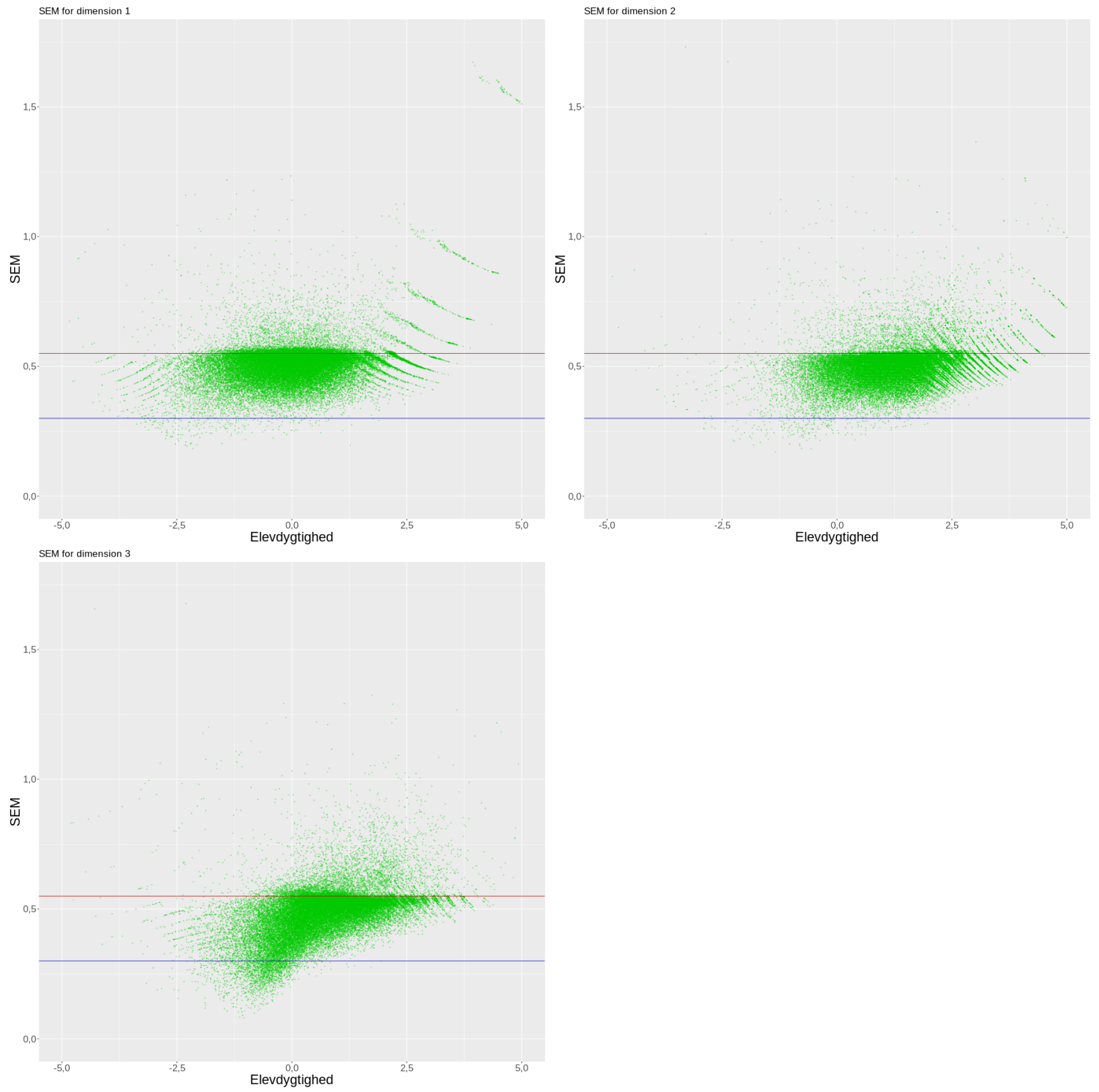

Figur 4.7 SEM i forhold til elevdygtighed.

Der er lagt en linje ind ved 0,3 (blå) og 0,55 (rød) logit for at illustrere hvor mange elever der ligger over de grænseværdier der har været nævnt i debatten om nationale test. Som det fremgår, når en stor del af eleverne ikke at få en SEM under de forventede 0,55. Faktisk er det ganske store procentdele som ligger over dette skæringspunkt. For profilområde 1 har 16 procent af eleverne en SEM over 0,55 og 100 procent af eleverne en SEM over 0,3. Gennemsnittet er 0,51. For profilområde 2 har 12 procent af eleverne en SEM over 0,55 og 100 procent af eleverne en SEM over 0,3. Gennemsnittet er 0,5. For profilområde 3 har 13 procent af eleverne en SEM over 0,55 og 96 procent af eleverne en SEM over 0,3. Gennemsnittet er 0,48. I tabel 4.5 gengives fordelingen af SEM for de tre profilområder.

Til sammenligning har den amerikanske nationale test Smarter Balanced i English Language Arts/Literacy 
Tabel 4.5 Fordeling af SEM for de tre profilområder (procentandele).

\begin{tabular}{cccc}
\hline SEM-interval & Profilområde 1 & Profilområde 2 & Profilområde 3 \\
\hline $0-0.3$ & 0,4 & 0,4 & 4,3 \\
$0.3-0.4$ & 5,2 & 5,4 & 12,8 \\
$0.4-0.5$ & 35,0 & 38,0 & 33,5 \\
$0.5-0.55$ & 43,3 & 44,0 & 36,8 \\
$0.55-0.6$ & 11,3 & 7,1 & 7,4 \\
$0.6-0.7$ & 2,9 & 3,4 & 3,5 \\
$0.7-1$ & 1,6 & 1,5 & 1,6 \\
$>1$ & 0,2 & 0,2 & 0,2 \\
\hline
\end{tabular}

Note:

Intervallerne indeholder ikke den nedre værdi, men den øvre.

Tabel 4.6 Oversigt over sandsynligheder for korrekte svar for opgaver med en sværhedsgrad der svarer til dygtigheden.

\begin{tabular}{ccc}
\hline & \multicolumn{2}{c}{ Sandsynligheder for korrekt svar } \\
\cline { 2 - 3 } SEM & I bunden af konfidensintervallet & I toppen af konfidensintervallet \\
\hline 0,20 & 0,40 & 0,60 \\
0,30 & 0,36 & 0,64 \\
0,40 & 0,31 & 0,69 \\
0,50 & 0,27 & 0,73 \\
0,55 & 0,25 & 0,75 \\
\hline
\end{tabular}

Note:

Sandsynlighedernes beregnes som funktioner af SEM for yderpunkterne i 95 procent-konfidensintervallet omkring estimatet af dygtigheden.

for elever i 8. klasse en SEM der ligger mellem 0,30 og 0,41 med et gennemsnit på 0,32 (Smarter Balanced Assessment Consortium 2018, 2-58) ${ }^{7}$.

En SEM på 0,55 er ganske betragtelig og langt ud over hvad man normalt ville acceptere for en pædagogisk test. Hvis estimatet af dygtigheden er tilnærmelsesvis normalfordelt, vil et 95 procent-konfidensinterval være defineret af dygtigheden $\pm 1,96 \times S E M$, og den sande dygtighed vil således med 95 procets sandsynlighed ligge inden for et interval hvor afstanden fra den mindste til den største værdi er lig med $3,92 \times S E M$. For at fortolke disse værdier kan man se på sandsynlighederne for korrekte svar på en opgave, der svarer til estimatet af dygtigheden, hvis den sande værdi var nede i bunden og oppe i toppen af konfidensintervallet. Tabel 4.6 viser disse sandsynligheder for forskellige værdier af SEM.

Udover at konkludere at en SEM-værdi på 0,20 fortæller nogenlunde samme historie om eleven i bunden og toppen af konfidensintervallet og helt forskellige historier hvis SEM er 0,55, vil vi overlade det til læseren at vurdere hvilke SEM værdier der skal betragtes som acceptable. Vi vil dog opfordre til at der gennemføres studier af hvilken størrelse af der kan accepteres under praktiske forhold. Sådanne studier kunne tage udgangspunkt i læreres begrundede vurdering af hvilke grupper af elever der adskiller sig dygtighedsmæssigt i en klasse, og sætte som mål at testen kan identificere et tilsvarende antal grupper som lærerne er i stand til.

\footnotetext{
${ }^{7}$ SEM er opgivet på den transformerede skala Smarter Balanced bruger (ibid. s. 5-4). Med en hældning på 85,8 svarer en SEM på 27,6 til 0,41 på logitskalaen.
} 


\subsubsection{Konfidensintervaller for percentilscorer}

Nationale test resultatside til lærerne viser elevernes dygtighed på en såkaldt percentilskala (som relaterer sig til en historisk population, ikke den aktuelle som eleven er en del af). Denne skala er valgt for at give læreren et forståeligt mål for elevens dygtighed, men den indebærer at elever i det midterste interval af skalaen vil have forsvindende små forskelle i estimeret dygtighed på logitskalaen (jævnfør fordelingen af elever i figur 4.5). Det betyder at usikkerhedsintervallet vist på percentilskalaen vil forekomme utrolig stort.

En beregning af percentilscorer for den undersøgte population (ikke den historiske som anvendes til at angive percentilscorer i nationale test) findes i bilag D.

For at finde konfidensintervallet for en elevs percentilscore skal man lægge konfidensintervallet om estimatet af dygtigheden på logitskalaen og derefter beregne percentilværdierne for konfidensintervallets yderpunkter.

Hvis dygtigheden er lig med 0 på logitskalaen, og hvis SEM er 0,55, skal grænserne for konfidensintervallet gå fra percentilværdien svarende til ca. -1,0 på logitskalaen til percentilværdien for ca. +1,0. I 2017-analysen for sprogforståelse svarer det et konfidensinterval for percentilscoren fra ca. 16 til ca. $84^{8}$.

Årsagen til det brede konfidensinterval er let at gennemskue når man ser på percentilkurverne til højre på figur 4.8. Alle kurver starter og slutter med at være meget flade, men er særdeles stejle i den største del af forløbet inde omkring logit-værdier på 0. Hvis man lægger konfidensintervallet på logitskalaen omkring værdierne $-2,5$ eller 2,5, vil konfidensintervallerne omkring percentilværdierne være meget snævrere.

Figur 4.8 viser konfidensintervaller for logit- og percentilskalaen. Det fremgår af diagrammet til venstre at eleverne generelt har et konfidensinteraval af nogenlunde samme størrelse målt på logitskalen. Diagramet til højre viser at percentilskalaens konfidensinterval er anderledes stort inde omkring midten. Bæltet omkring kurven snævrer ind jo længere væk man komme fra midtpunktet, og er nærmest eksploderet inde omkring midten.

Denne eksplosion bliver tydelig i det tredje plot, hvor vi har fremhævet konfidensintervallet for tre elever henholdsvis øverst i den første percentil (konfidensintervallet er mellem de blå horisontale linjer), i den 50. (mellem de røde linjer) og den 99. percentil (mellem de orange linjer). SEM for de tre elever er henholdsvis $0,27,0,51,0,31$, hvilket for alle tre elever er under gennemsnittet af SEM. De stiplede streger angiver henholdsvis elevens placering i forhold til andre elever og elevens dygtighed på logitskalaen.

I det venstre plot ses det at usikkerhederne er betydelige på logitskalaen, men også at de er af samme størrelsesorden på logitskalaen. Men når man ser på percentilværdierne, som jo er et udtryk for eleverne ligger i forhold til andre elever, bliver det tydeligt at fordi der er så mange elever omkring midten af dygtighedsintervallet, så vil percentilscoren have et meget stort konfidensinterval knyttet til sig.

Ved beslutningen om at indføre nationale test valgte man at anvende en adaptiv test i stedet for en simpel lineær test fordi adaptive test måler færdigheder med samme sikkerhed for alle elever. Figur 4.8 viser konsekvensen af at man samtidig valgte at rapportere testresultaterne på en måde der tilsidesætter denne fordel og giver resultater der for langt de fleste elever er så usikre at man må fraråde lærerne at lægge vægt på dem. Percentilscorer kan kun have betydning for beslutninger om meget svage elever og meget stærke elever.

\footnotetext{
${ }^{8}$ I Styrelsen for It og Lærings notat De nationale tests måleegenskaber (Styrelsen for It og Læring 2016c) angives det at gennemsnittet af 95 procent-konfidensintervallet er $\pm 12,5$ percentilpoint. Og i en figur angives det at intervallet omkring 50 . percentil er ca. \pm 17 . På baggrund af vores analyser af nationale test for dansk, læsning ligger intervallet snarere omkring \pm 34 .
} 

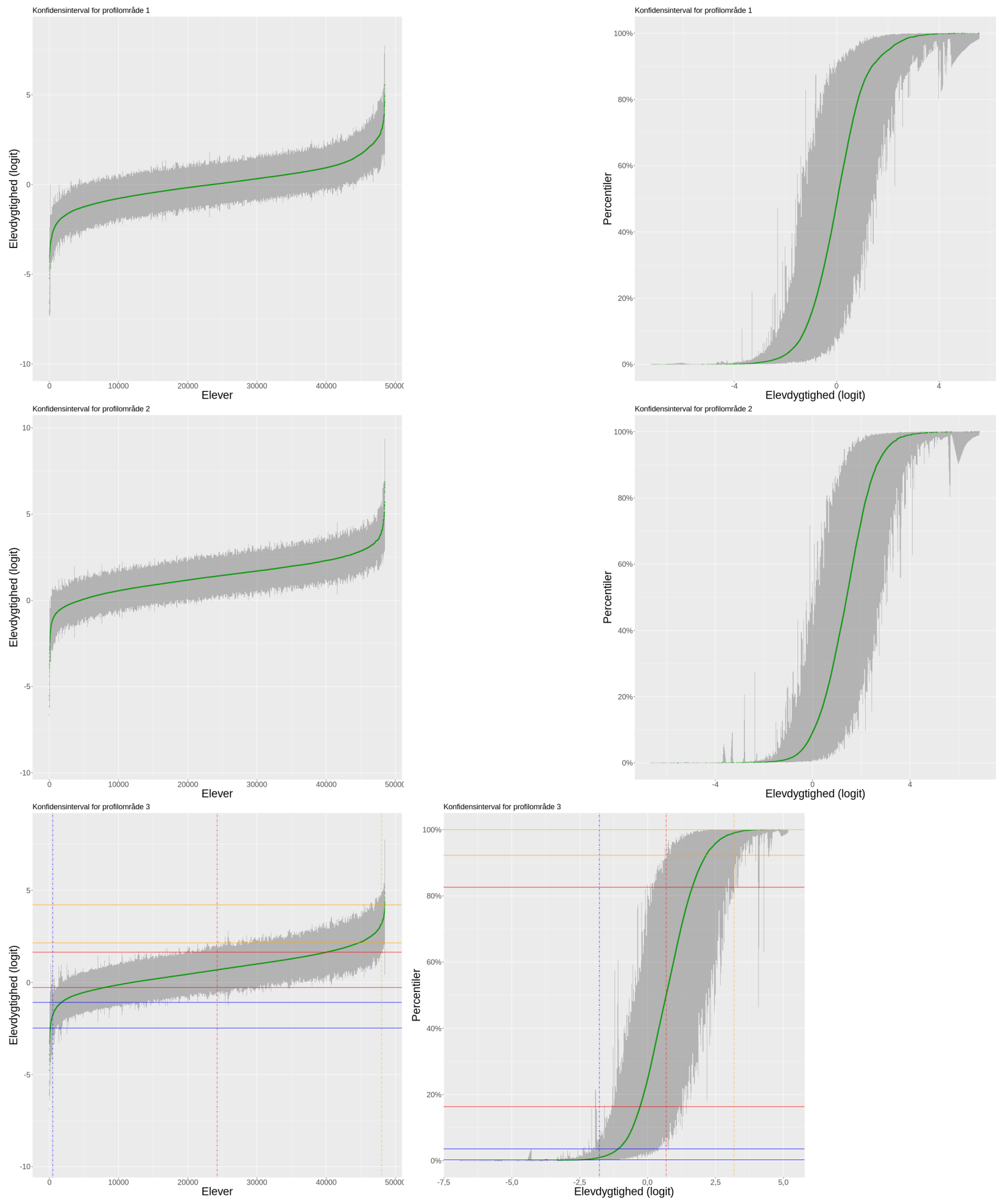

Figur 4.8 Elevdygtigheder med 95 procent-konfidensinterval ifølge 2017-analysen. Venstre side viser konfidensintervallerne for hver elev på hver af de tre profilområder på logitskalaen ifølge 2017-analysen. For at bestemme en elevs score med konfidensinterval finder man eleven på x-aksen (eleverne er sorteret efter stigende dygtighed). Så går man op til den grønne kurve, og her er estimatet af elevens dygtighed på y-aksen. Det grå område rundt om kurven er 95 procent-konfidensintervallet. Højre side viser konfidensintervallet på percentilskalaen. 


\subsubsection{Kriteriebaserede scorer}

De nationale test beregner elevernes dygtighed ved hjælp af estimater af Rasch-modellens personparameter på samme måde som det for eksempel er tilfældet i PISA og andre undersøgelser der anvender pædagogiske test. Disse parametre betragtes af mange som utilgængelige abstrakte størrelser. I stedet for at benytte disse værdier rapporterer nationale test resultaterne i form af percentilscorer med reference til fordelingen af elever i 2010 eller 2014 og i form af såkaldte kriteriebaserede scorer som har til hensigt at informere lærere og forældre om i hvilken grad fageksperter anser testresultaterne som mere eller mindre tilfredsstillende.

Percentilscorer og den usikkerhed der er knyttet til disse målinger, blev omtalt i forrige afsnit. Med hensyn til de kriteriebaserede scorer henvises til Bilag E hvor der er eksempler på hvorledes de rapporteres, og hvor man kan se at de kriteriebaserede scorer klassificerer testresultatet i en ud af følgende syv kategorier

1) Fremragende

2) Rigtig god

3) God

4) Jævn

5) Mangelfuld

6) Ikke tilstrækkelig

De betegnelser som nationale test knytter til de kriteriebaserede scorer, minder påfaldende om de korte betegnelser der er knyttet til det karaktersystem som anvendes i dag. I hvor høj grad dette er et tilfælde, er det ikke muligt at sige fordi ministeriet aldrig har dokumenteret præcis hvorledes kategorierne er defineret, og præcis hvad det er der fx karakteriserer et rigtig godt, men alligevel ikke fremragende præstation i nationale tests læseprøve.

Udgangspunktet for vurderingerne er at man har bedt fageksperterne om at udvælge et passende antal opgaver med varierende sværhedsgrader som eksperterne dels anså for gode opgaver, og som tilsammen dækker de færdighedsniveauer som elever på det pågældende klassetrin må forventes at ligge på. Wilson (2005) omtaler sådanne beskrivelser af opgaver og færdighedsniveauer som construct maps.

Det er som sagt uklart hvordan de seks niveauer er defineret, men hvis eksperterne har gjort det på den rigtige måde, har de gjort følgende:

a) Hver af de kriteriebaserede kategorier er defineret som et interval på skalaen med værdierne af Rasch-modellens personparametre. Den øvre grænse i et sådant interval angiver de dygtigste elever i kategorien, mens den nedre grænse referer til de mindst dygtige.

b) For både de dygtigste og de mindst dygtige beregnes først sandsynlighederne for at de udvalgte opgaver besvares korrekt ud fra personparametrene og sværhedsgraderne for opgaverne.

c) Ud fra disse sandsynligheder kan man dels beregne den samlede score på de udvalgte opgaver og dels identificere opgaver der er alt for vanskelige for eleverne i intervallet, og opgaver der er så lette at man kan argumentere at eleverne i det pågældende interval er kommet forbi og har styr på den type af problemer som opgaverne indeholder.

Fageksperternes kategoriseringer af præstationerne fra "Fremragende" til "Ikke tilstrækkelige" bør være og er formodentlig baseret på beregningerne i pkt. c. På grund af hemmelighedskræmmeriet omkring opgaverne er det imidlertid ikke muligt for fageksperterne at referere til konkrete opgaver fra testen hvilket i sagens natur gør det vanskeligt at dokumentere hvordan kategorierne er defineret, på en måde som lærere kunne have nytte af.

Uanset dette problem afslører analyserne i denne rapport at der kan være problemer med kategorierne fordi beregningerne af sandsynlighederne i pkt. b er baseret på forkerte oplysninger om opgavernes sværhedsgrader. Nogle opgaver, som man har troet var for vanskelige for elever på et bestemt niveau, er det måske ikke, mens andre opgaver, som så ud til at være meget lette for elever på et bestemt niveau, måske alligevel indeholder udfordringer for eleverne. 
Uden kendskab til hvilke opgaver som fageksperterne har baseret deres vurderinger på, er det naturligvis ikke muligt for os at udtale os om der er store eller små problemer med de kriteriebaserede scorer som nationale test benytter. Men risikoen er der, og som konsekvens heraf må sandsynlighederne for de valgte opgaver genberegnes og kategorierne kontrolleres i forhold til de korrekte sandsynligheder.

\subsection{Er der opgaver med passende sværhedsgrader til eleverne?}

I almindelige lineært opbyggede tests hvor alle elever får de samme opgaver, vil man tilstræbe at have mange opgaver dér hvor man er interesseret i at måle elevernes dygtighed med stor præcision. Er det en diagnostisk test vil det betyde at man vil have mange opgaver omkring skæringspunktet for diagnosen. Er det en sammenlignende måling, vil man have mange opgaver i midten af fordelingen af elevernes dygtighedsniveau og færre ude i yderområderne.

Eftersom en adaptiv test tilstræber at måle alle elevers dygtigheder med stor præcision, fordrer det at der er et stort antal opgaver over hele dygtighedsspektret. Det er særligt antallet af lette opgaver og antallet af svære opgaver der er kritisk. Der skal være opgaver nok til både de allerdygtigste og de allerdårligste, men det gør ikke noget at mange elever får de samme opgaver. Til gengæld skal der, hvis man ønsker at teste igen, være opgaver nok til to eller flere runder uden at eleverne får den samme opgave to eller flere gange.

Et Wright-map (Wilson 2003) tegner fordelingen af sværhedsgraderne ved siden af fordelingen af elevernes dygtighed på den samme skala og viser derved om opgavernes sværhedsgrader dækker dygtigheden blandt eleverne. Se figur 4.9. Histogrammerne til venstre viser fordelingen af elevernes dygtigheder, mens histogrammerne til højre viser hvor mange opgaver der er på hvert sværhedsgradsniveau. 

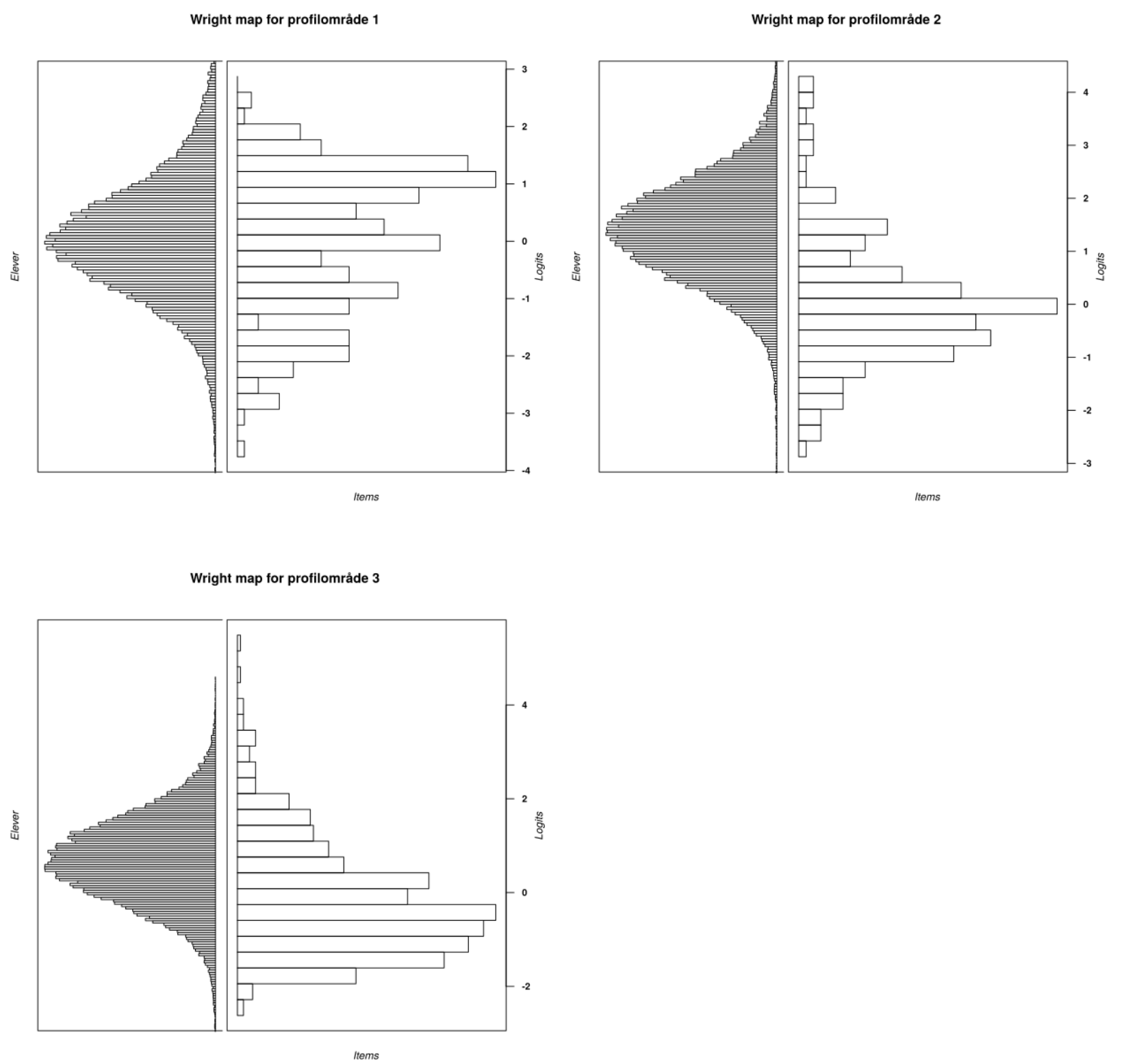

Figur 4.9 Wrightmaps for de tre profilområder.

Som det fremgår af de tre Wrightmaps, er tilpasningen mellem opgaver og elever ikke optimal for nationale test i dansk, læsning på 8. klassetrin. Profilområde 1, sprogforståelse, kommer tættest på idealet med et stort antal opgaver i midten og forholdsvis mange ude mod yderområderne, særligt i den høje ende. Havde testen været en almindelig lineær test, ville man betragte fordelingen af items på elever som yderst vellykket. Der er mange opgaver dér hvor der er mange elever.

Profilområde 2, afkodning, må betragtes som alvorligt underdimensioneret med opgaver i midten og den høje ende. Elever i midten af dygtighedsfordelingen og derover vil komme til at mangle opgaver på deres niveau, og derved vil de sandsynligvis opleve en stor mængde gengangere fra den frivillige til den obligatoriske test.

Også profilområde 3 har for få opgaver særligt hos de over middel dygtige elever. 
Tabel 4.7 Korrelationer mellem dimensioner. Standardafvigelser i diagonalen.

\begin{tabular}{lrrr}
\hline & Profilområde 1 & Profilområde 2 & Profilområde 3 \\
\hline Profilområde 1 & 0,63 & 0,80 & 0,68 \\
Profilområde 2 & 0,80 & 0,76 & 0,88 \\
Profilområde 3 & 0,68 & 0,88 & 0,71 \\
\hline
\end{tabular}

\subsection{Et, to eller tre profilområder?}

De foregående analyser giver anledning til at spørge om en af årsagerne til de problemer vi har observeret, skal findes i at testen ikke måler tre profilområder, men måske kun to eller et. Dette er et interessant og omdiskuteret teoretisk spørgsmål, men her vil vi blot undersøge det med statistiske metoder.

Til det formål er en række ekstra analyser af data foretaget. Analyser ved hjælp af flerdimensionelle Raschmodeller (de såkaldte MCML-modeller) giver bedre muligheder for at undersøge sammenhænge på tværs af dimensioner (profilområder). Item-analysen baseres på en MCML-model der antager at værdierne på de forskellige dimensioner følger en fler-dimensional normalfordeling hvor værdierne på de valgte dimensioner antages at være korrelerede. I en multidimensionel analyse behandles således alle data i samme estimation, men det angives over for algoritmen at der er tale om et bestemt antal dimensioner således at der kan beregnes og tages højde for korrelationerne mellem dimensionerne. I tabel 4.7 ses en korrelationer mellem de tre dimensioner i nationale test.

Af tabellen fremgår det at der er ret stærke korrelationer mellem de tre dimensioner (profilområder). Når man er god til afkodning er man også god til sprogforståelse og tekstforståelse og omvendt. Det er af den grund naturligt at spørge om disse korrelationer skyldes at de tre profilområder måler forskellige aspekter af én og samme færdighed. Hvis det er tilfældet ville man kunne forenkle afrapporteringen af testresultaterne ved kun at beregne en samlet score som til gengæld - fordi den var baseret på svar på flere opgaver - ville være mere sikker (mindre SEM) end de tre individuelle profilresultater.

Analyser ved hjælp af MCML-modeller giver bedre muligheder for at afprøve hypoteser om endimensionalitet med flerdimensionelle modeller som alternativ, fordi modelstrukturen i sådanne hypoteser og alternativer er eksplicit defineret som en del af modellen i form af kovarianserne i den multivariate normalfordeling for profilområderne.

For at afklare om nationale test måler en, to eller tre forskellige dimensioner, er følgende hypoteser blevet afprøvet:

- Model 1: Alle tre profilområder måler én og samme færdighed.

- Model 2: Profil 1 \& 2 måler samme færdighed. Profil 3 måler en særskilt færdighed.

- Model 3: Profil 1 \& 3 måler samme færdighed. Profil 2 måler en særskilt færdighed.

- Model 4: Profil 2 \& 3 måler samme færdighed. Profil 1 måler en særskilt færdighed.

- Model 5: De tre profilområder måler forskellige færdigheder.

For samtlige modeller skal itemsværhedsgrader og parametre for fordelingen af de bagvedliggende færdigheder estimeres for tilsammen 823 opgaver (1.156 items). Tabel 4.8 viser antallet af ukendte parametre for hver af de fem modeller samt de såkaldte deviance-værdier der skal bruges til at beregne likelihood ratio-test for en model som hypotese og en anden model som alternativ. Tabellen viser også to informationskriterier, der skal bruges til at vælge den bedste model, hvis resultaterne i den efterfølgende tabel skulle vise sig at være inkonsistente.

Da modellerne 1-4 alle er indlejret i Model 5, og da Model 1 er indlejret i modellerne 2-4, kan vi teste hypoteserne i tabel 4.9 . 
Tabel 4.8 Resultaterne af analyserne af fem modeller.

\begin{tabular}{lrrrr}
\hline Model & Parametre & Deviance & AIC & BIC \\
\hline Model 1: (Profil 1+2+3) & 1157 & 3614960 & 3617274 & 3627443 \\
Model 2: (Profil 1+2, Profil 3) & 1159 & 3605957 & 3608275 & 3618461 \\
Model 3: (Profil 1+3, Profil 2) & 1159 & 3609154 & 3611472 & 3621658 \\
Model 4: (Profil 2+3, Profil 1) & 1159 & 3602171 & 3604489 & 3614676 \\
Model 5: (Profil 1, Profil 2, Profil 3) & 1162 & 3614331 & 3616655 & 3626868 \\
\hline
\end{tabular}

${ }^{1}$ Deviance: Et mål for de empiriske datas afvigelse fra den teoretiske model.

${ }^{2}$ AIC: Akaike Information Criterion. Et mål for den relative kvalitet af en model.

${ }^{3}$ BIC: Bayesian Information Criterion. Et mål for den relative kvalitet af en model.

Tabel 4.9 Sammenligning af de fem modeller.

\begin{tabular}{llrrr}
\hline Hypotese & Alternativ & Likelihood-ratio & Frihedsgrader & $\mathrm{p}$ \\
\hline Model 1 & Model 2 & 9003 & 2 & 0 \\
Model 1 & Model 3 & 5806 & 2 & 0 \\
Model 1 & Model 4 & 12789 & 2 & 0 \\
Model 1 & Model 5 & 629 & 5 & 0 \\
Model 2 & Model 5 & -8374 & 3 & 0 \\
Model 3 & Model 5 & -5177 & 3 & 0 \\
Model 4 & Model 5 & -12160 & 3 & 0 \\
\hline${ }^{1}$ Likelihood-ratio: Forholdet mellem plausibiliteten & af to \\
modeller. & & &
\end{tabular}

Det fremgår af tabellen at der er højsignifikant $(\mathrm{p}=0)$ forskel på alle de sammenlignede modeller, $\mathrm{og}$ at hverken den unidimensionelle eller den tredimensionelle model beskriver data bedst (men den tredimensionelle er bedre end den unidimensionelle). Man kan ikke direkte sammenligne de tre alternative modeller via likelihood-ratioet, men AIC og BIC-værdierne er lavest for model 4, og dette kan bruges som argument for at profilområderne afkodning og tekstforståelse slås sammen. Dette ville dog være i modstrid med den tilgrundliggende teori om læsning: det såkaldte Simple view of reading (Hoover og Gough 1990)), der hævder at læsning (tekstforståelse) er lig med produktet af afkodning og sprogforståelse (Lasning = Afkodning $x$ Sprogforståelse). Uoverenstemmelsen kan enten skyldes at de tre dimensioner ikke operationaliserer teoriens tre faktorer korrekt, eller det kan være et tegn på at teorien falsificeres med disse data. Vi går ikke yderligere ind i denne interessante iagttagelse i denne sammenhæng, men vil opfordre til at det undersøges nærmere.

\subsection{Konklusioner og diskussion}

Vi har i dette kapitel undersøgt data fra nationale test, dansk, læsning, i 2017 og sammenlignet resultaterne med nationale tests udsagn om itemsværhedsgrader og elevdygtigheder.

Vi har identificeret en række problemer:

1) De sværhedsgrader som anvendes i nationale test, er ikke længere korrekte i 2017.

2) Denne uoverensstemmelse fører til en uoverensstemmelse i estimering af elevdygtigheder, som kan 
identificeres ved at se på fordelingen af elevernes dygtigheder som de er estimeret ud fra 2017-data, sammenlignet med dygtighederne estimeret af nationale test.

3) Uoverensstemmelsen viser sig at være systematisk således at nationale test undervurderer elever i den dårlige ende af skalaerne og overvurderer elever i den bedre ende af skalaerne, særligt i profilområde 2 og 3 . Forskellen på dygtige og mindre dygtige elever er altså mindre end nationale test konkluderer.

4) Der er ikke tilstrækkeligt med opgaver for de dygtige elever i to profilområder, og i et profilområde mangler tillige opgaver til de middeldygtige elever.

5) Usikkerheden på estimatet af elevernes dygtighed er for stor, og for en ganske stor andel (ca. 15 procent) af eleverne er der tale om endnu større usikkerheder end den i forvejen høje grænse for SEM på 0,55. Problemet skyldes i et vist omfang at nationale test regner med forkerte sværhedsgrader, men problemet ville også være der hvis nationale tests sværhedsgrader var korrekte. SEM-værdier over 0,5 er i vores $\varnothing$ jne uacceptable i forbindelse med individuel vurdering af testresultater.

6) Der er ikke belæg i data for at sige at de tre profilområder måler én og samme færdighed, men analysen tyder på at det kan give mening at se afkodning og tekstforståelse som én dimension.

De observerede forskelle på hvad DNT anvender som sværhedsgrader, og de sværhedsgrader som items faktisk har (2017-analysen), vil have betydelige konsekvenser for hvordan den adaptive algoritme opfører sig. For det første vil den adaptive algoritme vælge opgaver som reelt ikke passer til elevens dygtighed, og eleven vil derfor ikke svare som forventet. Det betyder at eleven vil være længere tid om at nå et tilstrækkeligt sikkert resultat. For det andet vil estimatet af usikkerheden hvile på forkerte itemsværhedsgrader, og algoritmen kan derfor stoppe for tidligt (eller for sent). Og endelig vil estimatet af elevens dygtighed hvile på forkerte itemsværhedsgrader og derfor være forkert. Det sidste er naturligvis det mest bekymrende.

Forskellen på fordelingerne baseret på DNT's beregninger og på 2017-analysen betyder at DNT tegner et forkert billede af fordelingerne af færdighederne i $2017 \mathrm{og}$ især et forkert billede af fordelingen af de dygtigste og de mindst dygtige. Og det betyder at fordelingen af dygtigheden i 2014 sådan som DNT beregnede det, ikke kan sammenlignes med fordelingen i 2017. Konsekvensen af dette er at effekten af skolereformen ikke kan evalueres ved sammenligning af DNT's tal fra 2014 og fra 2017, således som det er forudsat i den politiske aftale fra 2013 ("Aftale Mellem Regeringen (Socialdemokraterne, Radikale Venstre Og Socialistisk Folkeparti), Venstre Og Dansk Folkeparti Om et Fagligt Løft Af Folkeskolen" 2013). 


\section{Analyser af enkeltstående testforløb}

\section{$5.1 \quad$ Indledning}

Dette kapitel beskriver analyser af enkeltstående testforløb. Testforløbene er ikke udvalgt tilfældigt, men således at de kan illustrere to forskellige forhold.

For det første hvorledes den adaptive algoritme fungerer hvis man tager hensyn til opgavernes sande sværhedsgrader således som de er estimeret i 2017-analysen. I og med at analysen i kapitel 4 viste at der er meget store forskelle på de sværhedsgrader som den adaptive algoritme benytter, og de sande sværhedsgrader i 2017, men at der også var en høj grad af enighed om hvad der var let og hvad der var vanskeligt, forventes det at den adaptive algoritmes valg af nye opgaver stadig giver en vanskeligere opgave hvis den foregående opgave blev besvaret korrekt, og lettere hvis den blev besvaret forkert. Det forventes også at sværhedsgraderne af valget af opgaver ligger længere væk fra det aktuelle bud på dygtigheden, og at sikkerheden er dårligere end den usikkerhed der ville have været opnået hvis nationale tests oplysninger om sværhedsgraderne havde været korrekte.

For det andet vil det blive undersøgt om svarene i et enkelt testforløb fordeler sig på en måde der passer til en Rasch-model med sværhedsgraderne fra 2017. Årsagen til at dette problem tages op, er de mange fortællinger om "mærkelige" testforløb hvor lærere giver udtryk for en sund skepsis med hensyn til om målingerne af færdighederne stemmer overens med elevernes faktiske dygtigheder.

Fortællingerne om mærkelige testforløb bærer i mange tilfælde præg af at brugerne ikke helt kan gennemskue at testresultaterne er probabilistiske, og at mærkelige testforløb både kan og vil forekomme, men det betyder naturligvis ikke at mistroen er ubegrundet. For at undersøge dette problem har vi derfor udvalgt en række testforløb med fordelinger af svarene der svarer til de fortællinger man hører om, og vi vil beregne og vurdere sandsynligheder for at sådanne forløb kan forekomme hvis hele elevens testadfærd rent faktisk afspejler dygtigheden på den måde som Rasch-modellen og den adaptive algoritme forventer.

Mulighederne og nytteværdien af kontrol af enkeltstående testforløb og behovet for at der blev givet en advarsel, hvis der var et eller andet påfaldende ved forløbet, blev allerede diskuteret i forbindelse med udviklingen af nationale test uden at blive implementeret.

Det næste afsnit giver en kort beskrivelse af metoderne, hvorefter de følgende afsnit giver eksempler på anvendelserne og diskuterer konsekvenserne af resultaterne.

\subsection{Metoder til at teste om enkelte testforløb kan beskrives ved hjælp af Rasch- modellen}

Metoderne til afprøvning af om enkeltstående testforløb passer til en Rasch-model svarer til Fischers såkaldte eksakte test for uafhængighed i $2 \times 2$-tabeller.

I Fischers test beregnes den betingede sandsynlighed for tallene i tabellen givet række- og søjlesummerne under forudsætning af at de to variable er indbyrdes uafhængige. Denne sandsynlighed benyttes som 
teststørrelsen ud fra den betragtning at en lille sandsynlighed er udtryk for at man har observeret noget uventet evt. grænsende til det usandsynlige hvis hypotesen om uafhængighed er korrekt. Da der kan være mange forskellige tabeller der giver de samme række- og søjlesummer, og da summen af sandsynlighederne for alle disse tabeller er lig med 1, følger det at den beregnede sandsynlighed kan være ganske beskeden uden at det i sig selv er udtryk for signifikant evidens mod hypotesen om uafhængighed. For at løse dette problem foreslog Fisher at beregne sandsynlighederne for samtlige tabeller med de givne række- og søjlesummer og at definere graden af signifikans som sandsynligheden for at observere en tabel der er lige så usandsynlig som eller mere usandsynlig end sandsynligheden for den observerede tabel.

Det er den samme måde vi vil benytte til at vurdere om det observerede svarmønster svarer til den adaptive algoritmes forventning om svar der passer til Rasch-modellen.

For hvert forløb beregnes den betingede sandsynlighed for svarmønstret givet sværhedsgraderne på items og det samlede antal point som eleven har opnået. Beregningerne af sandsynligheder kan være lidt komplicerede og vil ikke blive gennemgået her, men interesserede læsere kan finde flere detaljer i bilag B.

Vurderingen af om det observerede svarmønster er udtryk for signifikant evidens mod påstanden om at svarene kommer fra en Rasch-model, baseres på følgende sandsynligheder:

1) Sandsynligheden for at svarmønstret på opgaver fra en Rasch-model med de kendte sværhedsgrader giver et endnu mere usandsynligt svarmønster end det der rent faktisk er observeret. Selvom det observerede svarmønster i sig selv har en lille sandsynlighed for at forekomme, kan det jo godt tænkes at der er mange andre svarmønstre der er endnu mere usandsynlige, og hvis disse tilsammen har en stor sandsynlighed for at forekomme, kan man ikke påstå at det observerede svarmønster i sig selv er udtryk for manglende tilpasning til Rasch-modellen.

2) For hver enkelt opgave beregnes sandsynligheden for det givne svar givet det samlede antal korrekte svar på opgaverne. Hvis en elev har svaret korrekt på næsten alle opgaver, inklusive mange vanskelige opgaver, er et forkert svar på en meget let opgave udtryk for at der må være et eller andet der har forstyrret eleven mens denne opgave blev løst, hvis sandsynligheden for det givne svar er meget lille.

3) For hver eneste værdi af $\mathrm{k}$ beregnes sandsynligheden for at værdien af $R_{k}$ er mindre end eller lig den observerede værdi, hvor $R_{k}$ er lig med antal rigtige svar på de $\mathrm{k}$ første opgaver. Hvis denne sandsynlighed er lille, er det et udtryk for at man har observeret en usandsynlig dårlig start på forløbet af testen. I tabel 5.4 ses et forløb hvor $R_{7}=0$, og hvor sandsynligheden for at de første syv opgaver besvares forkert, når der tilsammen scores 13 ud af 21 mulige point, er mindre end 0,005. Et resultat der ville være usandsynligt hvis elevens dygtighed var kommet til udtryk på den måde som det er krævet af Rasch-modellen.

De to første sandsynligheder bruges til at vurdere signifikansen af henholdsvis det samlede svarmønster og svarene på de enkelte opgaver, men den tredje sandsynlighed bruges til at vurdere signifikansen af forløb med mange forkerte svar i starten eller slutningen af forløbet.

Eksemplet i de næste to afsnit vil illustrere metoderne for to forskellige forløb, hvorefter resultaterne for de $\varnothing$ vrige forløb vil blive opsummeret og diskuteret.

\subsection{Et adaptivt forløb}

Først vises et eksempel på et forløb hvor eleven har svaret skiftevis rigtigt og forkert. Dette kan siges at være et tæt på ideelt adaptivt forløb som dog slutter u-adaptivt. 
Tabel 5.1 Forløb for elev 441985, profilområde 2

\begin{tabular}{lrrrr}
\hline Opgavenummer & Score & Kummuleret score & 2017-sværhedsgrader & DNT-sværhedsgrader \\
\hline 0108020115072 & 1 & 1 & 1,38 & 1,9 \\
$010802000301234810-1$ & 0 & 1 & 1,43 & 2,6 \\
$010802000301234966-1$ & 1 & 2 & 1,35 & 2,0 \\
$010802000301234959-1$ & 0 & 2 & 1,98 & 2,8 \\
$010802000301234953-1$ & 1 & 3 & 1,41 & 2,2 \\
$010802000301234951-1$ & 0 & 3 & 2,06 & 2,7 \\
0108020111026 & 1 & 4 & 0,84 & 2,3 \\
$0108020110139-1$ & 0 & 4 & 1,27 & 2,7 \\
0108020111022 & 1 & 5 & 1,53 & 2,5 \\
$010802000301234848-1$ & 0 & 5 & 2,07 & 2,6 \\
0108020111019 & 1 & 6 & 1,37 & 2,6 \\
$010802000301238021-1$ & 1 & 7 & 1,32 & 3,0 \\
0108020111006 & 0 & 7 & 1,38 & 2,9 \\
0108020110268 & 0 & 7 & 2,25 & 3,3 \\
$0108020110166-1$ & 1 & 8 & 2,09 & 3,5 \\
$010802000301239338-1$ & 1 & 9 & 2,92 & 3,7 \\
$010802000301239337-1$ & 0 & 9 & 3,36 & 3,7 \\
\hline
\end{tabular}

Elev_id: 441985 - Profilområde 2

Resultat: $1,0,1,0,1,0,1,0,1,0,1,1,0,0,1,1,0 \mid 9$ rigtige af 17

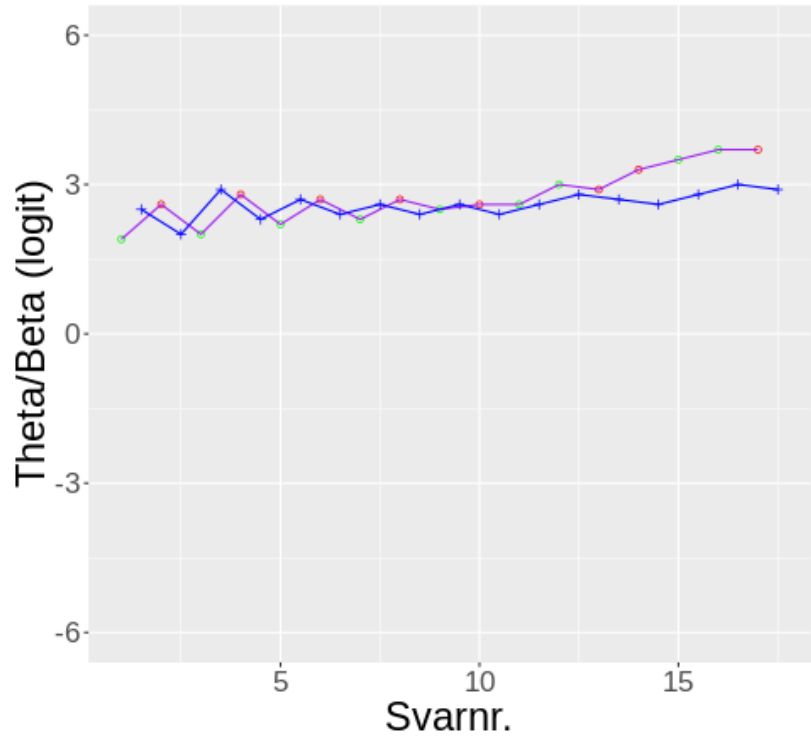

Testforløb ifølge 2017-analysen

6 -

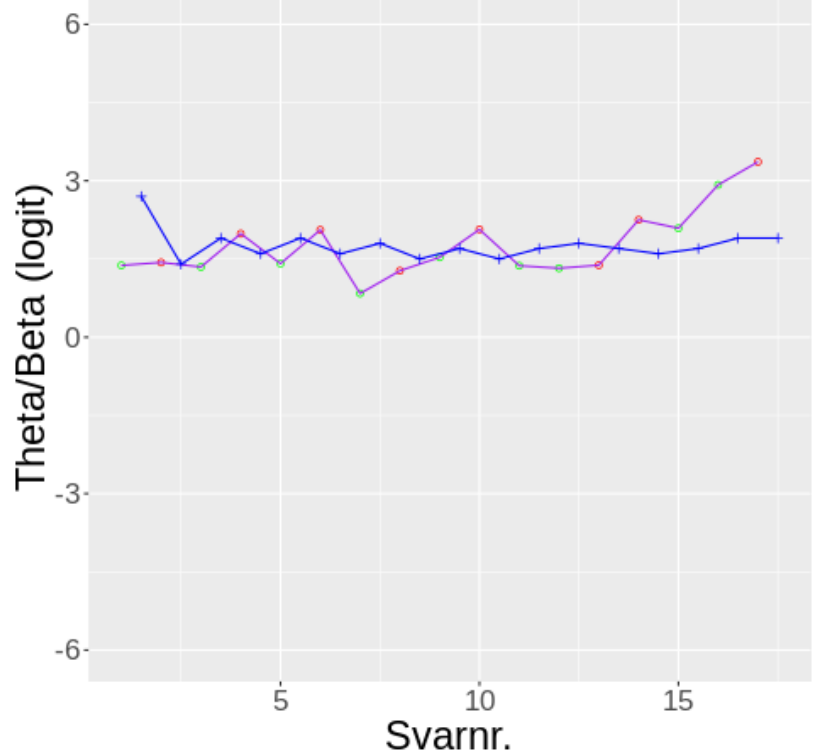

Figur 5.1 Testforløb for elev 441985, profilområde 2. Diagrammet til venstre viser data fra DNT's analyser af elevens forløb med anvendelse af DNT's itemsværhedsgrader. Rækkefølgen af de items eleven har besvaret, ligger på x-aksen. På y-aksen ses opgavernes sværhedsgrad. Hvis opgaven besvares korrekt, er den grøn, hvis den besvares forkert, er den rød. Hvis det er et polytomt item hvor nogle svar er korrekte, er prikken orange. Items er forbundet med en lilla linje. Den blå linje med blå krydser viser hvordan elevens dygtighed er estimeret efter den seneste opgave (derfor er punktet placeret mellem to items). Diagrammet til højre viser det samme baseret på 2017-analysens estimater. 
Tabel 5.2 Oplysninger om testforløbet for elev 441985 baseret på 2017-sværhedsgraderne.

\begin{tabular}{|c|c|c|c|c|c|c|c|c|}
\hline \multirow[b]{2}{*}{ itemno } & \multirow[b]{2}{*}{ opgavenummer } & \multicolumn{4}{|c|}{ Betingede sandsynligheder } & \multicolumn{2}{|c|}{ Dygtighedsestimater } & \multirow[b]{2}{*}{ Next } \\
\hline & & score & scoreprob & cumulated & cumulatedprob & WML & SEM & \\
\hline 1 & 108020115072 & 1 & 0,630 & 1 & 0,630 & & & \\
\hline 2 & 010802000301234810-1 & 0 & 0,391 & 1 & 0,503 & & & \\
\hline 3 & 010802000301234966-1 & 1 & 0,633 & 2 & 0,481 & 1,92 & 1,05 & 1,99 \\
\hline 4 & 010802000301234959-1 & 0 & 0,528 & 2 & 0,405 & 1,55 & 0,99 & 1,42 \\
\hline 5 & 010802000301234953-1 & 1 & 0,621 & 3 & 0,416 & 1,87 & 0,91 & 2,05 \\
\hline 6 & 010802000301234951-1 & 0 & 0,546 & 3 & 0,365 & 1,61 & 0,83 & 0,87 \\
\hline 7 & 108020111026 & 1 & 0,746 & 4 & 0,387 & 1,77 & 0,78 & 1,29 \\
\hline 8 & 0108020110139-1 & 0 & 0,347 & 4 & 0,281 & 1,48 & 0,73 & 1,53 \\
\hline 9 & 108020111022 & 1 & 0,593 & 5 & 0,358 & 1,69 & 0,69 & 2,09 \\
\hline 10 & 010802000301234848-1 & 0 & 0,554 & 5 & 0,275 & 1,55 & 0,65 & 1,37 \\
\hline 11 & 108020111019 & 1 & 0,634 & 6 & 0,359 & 1,70 & 0,62 & 1,34 \\
\hline 12 & 010802000301238021-1 & 1 & 0,641 & 7 & 0,426 & 1,83 & 0,60 & 1,39 \\
\hline 13 & 108020111006 & 0 & 0,370 & 7 & 0,297 & 1,65 & 0,57 & 2,28 \\
\hline 14 & 108020110268 & 0 & 0,604 & 7 & 0,157 & 1,56 & 0,55 & 2,12 \\
\hline 15 & 0108020110166-1 & 1 & 0,437 & 8 & 0,339 & 1,73 & 0,53 & 2,98 \\
\hline 16 & 010802000301239338-1 & 1 & 0,238 & 9 & 0,831 & 1,93 & 0,52 & 3,39 \\
\hline 17 & 010802000301239337-1 & 0 & 0,831 & 9 & 1,000 & 1,88 & 0,51 & \\
\hline
\end{tabular}

Note:

${ }^{1}$ Scoreprob: Sandsynligheden for at eleven med den estimerede dygtighed vil svare som det skete, på denne opgave.

${ }^{2}$ Cumulatedprob: Sandsynligheden for at eleven med den estimerede dygtighed vil have haft det givne forløb indtil dette item.

${ }^{3}$ WML: Weighted Maximum Likelihood-estimat af elevens dygtighed på dette tidspunkt.

${ }^{4}$ SEM: Standard Error of Measurement for det estimerede resultat på dette tidspunkt

${ }^{5}$ Next: Næste opgaves sværhedsgrad.

Elev 441985 har, som vist i tabel 5.1, opnået ni point på 17 opgaver fra profilområde 2. Tabellen viser både sværhedsgraderne estimeret i datamaterialet fra 2017 og de sværhedsgrader som den adaptive algoritme benytter til estimation af elevens dygtighed. Bemærk at man ikke skal lægge vægt på den systematiske forskel der fortæller at DNT's sværhedsgrader er større end sværhedsgraderne i 2017. Det man skal lægge mærke til, er forskellen på sværhedsgraderne. Ifølge DNT's oplysninger er sværhedsgraden næsten den samme for de to sidste opgaver. Ifølge 2017-analysen er den sidste opgave den vanskeligste med en sværhedsgrad der ligger 0,40 over sværhedsgraden for den næstsidste.

Forløbet for elev 441985 er også vist i figur 5.1. Som det fremgår af den venstre side af figuren har algoritmen skiftevis estimeret elevens dygtighed højere og lavere og derved stillet en opgave der var sværere og lettere, og eleven har svaret skiftevis forkert og rigtigt (evt. to i træk). I et optimalt adaptivt forløb ville kurven med opgaverne ligge parallelforskudt en smule til højre for kurven med dygtigheden. Det sker i starten af forløbet, men mod slutningen begynder algoritmen at give opgaver der er væsentligt sværere end elevens dygtighed er vurderet til. Det kunne tyde på at der ikke er flere opgaver lige omkring elevens estimerede dygtighed. På figuren til højre er der endnu større uoverensstemmelse mellem estimeret dygtighed og efterfølgende opgave (omkring opgave 7, 8 og 12). Her bliver det tydeligt at de aktuelle sværhedsgrader på de items der tildeles, afviger fra estimatet af dygtigheden.

I tabel 5.7 sidst i dette kapitel er elevens dygtighed ifølge henholdsvis 2017-analysens og DNT's estimat gengivet som en percentilplacering.

I tabel 5.2 findes det samme testforløb suppleret med oplysninger der kan bruges til at vurdere om denne elev har besvaret opgaverne på en måde der svarer til Raschmodellens påstand om at resultatet kun afhænger af 
elevens dygtighed og opgavens sværhedsgrad. For hver opgave er beskrevet den betingede sandsynlighed for scoren givet sværhedsgraderne (fra 2017) og elevens endelige scoreresultat, sandsynligheden for den kummulerede score (eller lavere) på det givne trin i forløbet, samt dygtigheden og SEM beregnet på det givne trin i forløbet. Den sidste søjle angiver sværhedsgraden af næste opgave i forløbet.

Til slut i forløbet er dygtigheden i 2017-analysen estimeret til 1,9 med en SEM på 0,51. Da den bedst mulige SEM der kunne opnås med 17 opgaver, er 0,48, kan det konstateres at det mindre end optimale valg af opgaver kun har haft en begrænset betydning for usikkerheden af denne elevs dygtighed. At en SEM-værdi på 0,51 må betragtes som et udtryk for en større usikkerhed end man bør forlange af en pædagogisk test, har ikke noget at gøre med udvalget af opgaver for denne elev. Det skyldes at antallet af opgaver eleven har besvaret, er for lille.

Oplysningerne der findes i tabellen, kan også bruges til at vurdere tilpasningen til Rasch-modellen ved beregninger af den betingede sandsynlighed for det observerede svarmønster givet at eleven har besvaret ni ud af 17 opgaver rigtigt. Det vil sige om det i det store og hele - på nær noget, der kan forklares som konsekvenser af ren tilfældighed - er sådan at eleven har svaret korrekt på de letteste opgaver og forkert på de vanskeligste.

I dette tilfælde er sandsynligheden for det observerede svarmønster 0,000093. Dette er en meget lille sandsynlighed, men hvis man undersøger samtlige mulige måder hvorpå der kan scores præcis ni point, vil man opdage at der er mange forløb der er endnu mere usandsynlige end det observerede forløb. Da den samlede sandsynlighed for at observere et svarmønster der er mere usandsynligt end det observerede, er 0,253, er konklusionen at forskellen på elevens svarmønster og Rasch-modellens forventninger til svarmønstret er insignifikant. Hypotesen om at det samlede svarmønster kommer fra en Rasch-model med sværhedsgraderne fra 2017, forkastes derfor ikke af denne test.

Med hensyn til spørgsmålet om hvorvidt der er svar på enkelte opgaver der ikke svarer til Rasch-modellens forventninger, afslører tabel 5.2 heller intet som kan betragtes som signifikant. Det korrekte svar på den næstsidste opgave er det mest usandsynlige, men sandsynligheden for at denne elev svarer korrekt på denne opgave, er trods alt lig med 0,24. Altså langt fra overraskende.

Da der heller ikke er noget, som kan betragtes som usandsynligt i forhold til det samlede resultatet for dele af testresultat, hvor det mest usandsynlige er at der scores syv point på de første 14 opgaver $(\mathrm{p}=0,16)$, er der kun én konklusion: Dette testforløb er en smuk illustration af, hvordan et adaptivt testforløb forventes at forløbe. Med nogle få undtagelser til sidst i forløbet skiftes der mellem rigtige og forkerte svar, og det samlede antal korrekte svar er lig med halvdelen af det antal opgaver der er stillet. Testforløbet er desuden karakteriseret ved at de første tre opgaver passer til elevens niveau, og at der af den grund ikke spildes tid med for lette eller vanskelige opgaver i starten af forløbet.

Men sådan er det langt fra for alle elever alene af den grund at langt fra alle elever møder opgaver på deres eget niveau i de første opgaver i det adaptive forløb. Det ville klart være at foretrække hvis den adaptive algoritme var implementeret således at alle elever mødte opgaver tættere på deres faktiske dygtighed i starten af forløbet.

\subsubsection{Analyser baseret på sværhedsgrader fra nationale test}

Analyserne i det foregående eksempel illustrerer hvorledes den adaptive algoritme ville have fungeret hvis man havde benyttet sværhedsgraderne fra 2017 til beregningen af dygtigheden, men havde beholdt de udvalgte opgaver, selvom dette udvalg af opgaver havde forholdt sig til de historiske sværhedsgrader.

Venstre side af figur $5.1 \mathrm{og}$ tallene i tabel 5.3 viser hvorledes tingene ville have fungeret hvis DNT's sværhedsgrader havde været korrekte.

Forskellen på forløbene i figur 5.1 er først og fremmest at det er tydeligt at udviklingen i sværhedsgrader i venstre side af figuren ligger tæt op ad udviklingen af estimaterne af dygtigheden således som den skal i et velfungerende adaptivt system.

Dette kan også ses hvis man sammenligner tallene i tabel 5.3 og tabel 5.2. I tabel 5.2 er forskellene mellem 
Tabel 5.3 Oplysninger om testforløbet for elev 441985 baseret på DNT’s sværhedsgrader.

\begin{tabular}{|c|c|c|c|c|c|c|c|c|}
\hline \multirow[b]{2}{*}{ itemno } & \multirow[b]{2}{*}{ opgavenummer } & \multicolumn{4}{|c|}{ Betingede sandsynligheder } & \multicolumn{2}{|c|}{ Dygtighedsestimater } & \multirow[b]{2}{*}{ Next } \\
\hline & & score & scoreprob & cumulated & cumulatedprob & WML & SEM & \\
\hline 1 & 108020115072 & 1 & 0,730 & 1 & 0,730 & & & \\
\hline 2 & 010802000301234810-1 & 0 & 0,417 & 1 & 0,487 & & & \\
\hline 3 & 010802000301234966-1 & 1 & 0,725 & 2 & 0,492 & 2,69 & 1,06 & 2,79 \\
\hline 4 & 010802000301234959-1 & 0 & 0,476 & 2 & 0,356 & 2,32 & 1,00 & 2,23 \\
\hline 5 & 010802000301234953-1 & 1 & 0,668 & 3 & 0,403 & 2,65 & 0,91 & 2,65 \\
\hline 6 & 010802000301234951-1 & 0 & 0,438 & 3 & 0,285 & 2,36 & 0,84 & 2,30 \\
\hline 7 & 108020111026 & 1 & 0,650 & 4 & 0,350 & 2,61 & 0,78 & 2,70 \\
\hline 8 & 0108020110139-1 & 0 & 0,450 & 4 & 0,239 & 2,40 & 0,72 & 2,48 \\
\hline 9 & 108020111022 & 1 & 0,605 & 5 & 0,321 & 2,61 & 0,68 & 2,65 \\
\hline 10 & 010802000301234848-1 & 0 & 0,437 & 5 & 0,202 & 2,43 & 0,64 & 2,62 \\
\hline 11 & 108020111019 & 1 & 0,569 & 6 & 0,298 & 2,62 & 0,62 & 3,04 \\
\hline 12 & 010802000301238021-1 & 1 & 0,457 & 7 & 0,405 & 2,82 & 0,60 & 2,92 \\
\hline 13 & 108020111006 & 0 & 0,510 & 7 & 0,319 & 2,68 & 0,57 & 3,31 \\
\hline 14 & 108020110268 & 0 & 0,612 & 7 & 0,196 & 2,59 & 0,55 & 3,46 \\
\hline 15 & 0108020110166-1 & 1 & 0,350 & 8 & 0,436 & 2,77 & 0,53 & 3,72 \\
\hline 16 & 010802000301239338-1 & 1 & 0,291 & 9 & 0,706 & 2,96 & 0,52 & 3,71 \\
\hline 17 & 010802000301239337-1 & 0 & 0,706 & 9 & 1,000 & 2,88 & 0,50 & \\
\hline
\end{tabular}

Note:

Se foregående tabel for forklaring af parametre.

de aktuelle estimater af dygtigheden og sværhedsgraden af den efterfølgende opgave mindre end i tabel 5.3. Da dygtighed og sværhedsgrad skal passe til hinanden, hvis den adaptive algoritme fungerer efter hensigten, skal der også være en stærk korrelation mellem dygtigheden og sværhedsgraden af den næste opgave. I tabel 5.3 er denne sammenhæng lig med 0,59, hvilket ganske vist er højsignifikant, men alligevel meget svagere end i tabel 5.2 hvor korrelationen er lig med 0,82.

Eller, med andre ord: hvis DNTs sværhedsgrader havde været anvendelige i 2017 ville den adaptive algoritmen have fungeret perfekt. Da det ikke er tilfældet, fungerer den dårligere.

\subsection{Først flere forkerte svar, derefter mange rigtige}

De følgende testforløb har alle først nogle forkerte og dernæst mange rigtige svar. 
Elev_id: 421613 - Profilområde 3

Resultat: $0,0,0,0,0,0,0,1,1,1,1,1,1,0,1,4 / 4,1,1 \mid 13$ rigtige

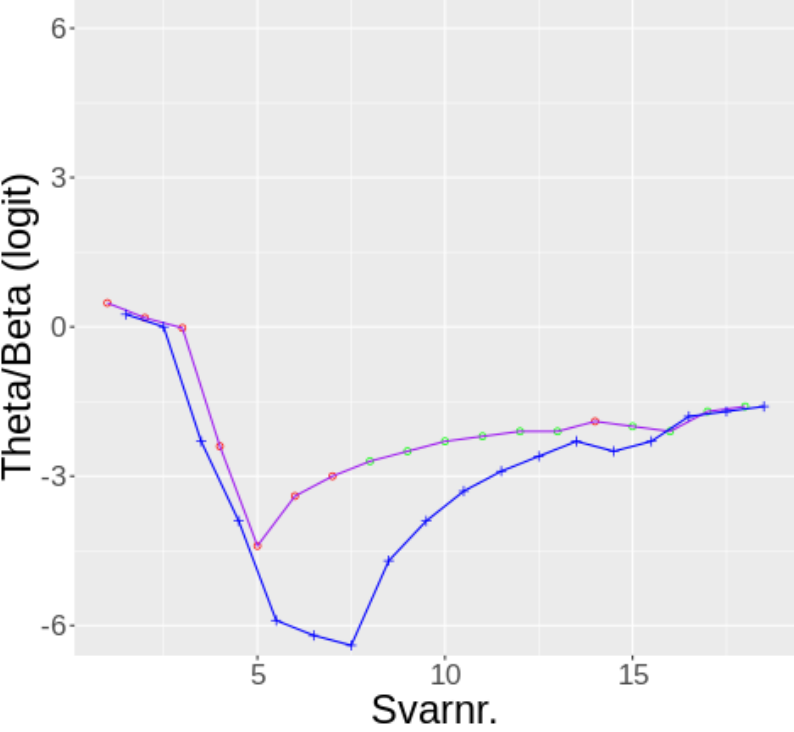

Testforløb ifølge 2017-analysen

$6-$

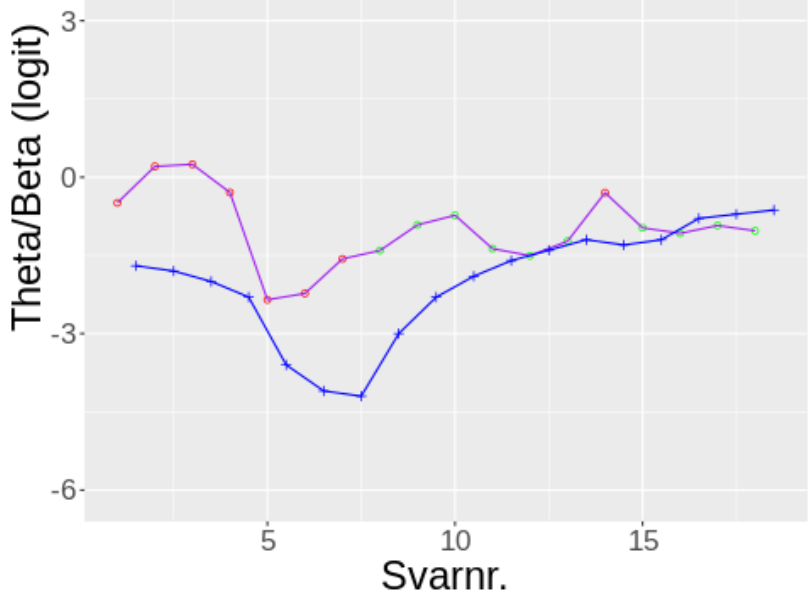

Figur 5.2 Testforløb for elev 421613, profilområde 3. Se forklaring i figur 5.1.

Elev 421613 lægger som det fremgår af figur 5.2, ud med syv forkerte. Eleven fortsætter med at lave fejl og algoritmen fortsætter med at reducere estimatet af dygtigheden indtil den efter syv forkerte er nede på -6,38 logit. Derefter laver eleven 13 korrekte og svarer kun et enkelt forkert.

Den ene af de 18 opgaver er en superitem-opgave med fire spørgsmål. I sådanne opgaver er sværhedsgraden ikke altid veldefineret. Nationale tests adaptive algoritme vælger derfor opgaver ud fra hvor opgaven er mest informativ. I dette tilfælde er det for personer med en dygtighed på -1.10. Omkring dette punkt er opgaven med de fire spørgsmål dobbelt så informativ som fire enkeltstående opgaver ville være. Hvis opgaven vælges på den rigtige måde vil testresultatet for denne elev altså svare til resultatet af 21 dikotome opgaver.

Figurerne afslører et fænomen som kan iagttages i flere testforløb fra 2017. Disse forløb er karakteriseret ved et påfaldende stort antal forkerte svar i begyndelsen af forløbet efterfulgt af perioder hvor eleverne tilsyneladende ikke har problemer med også at besvare vanskelige opgaver.

Visuelle indtryk som dem der ses i de to figurer, kan imidlertid være misvisende, blandt andet fordi den adaptive algoritme starter med at vælge opgaver i midten af fordelingen af dygtighederne, således at de mindst dygtige elever bliver bedt om at besvare opgaver der er alt for vanskelige for dem, og først får opgaver hvor der er en fair mulighed for et korrekt svar, når estimationen af dygtigheden kommer ned på elevens niveau.

I første omgang kunne man få det indtryk at dette kunne være tilfældet her. I hvert fald er sandsynligheden for det observerede forløb givet den samlede score på 13 ikke så usandsynligt så det i sig selv er udtryk for signifikant misforhold mellem det observerede og det forventede $(\mathrm{p}=0,24)$.

Analyserne i tabel 5.4 fortæller imidlertid en anden historie. Beregningerne af sandsynlighederne for svar på enkelte opgaver finder i første omgang intet påfaldende. De mest usandsynlige begivenheder er de forkerte svar på den femte og sjette opgave hvor sandsynlighederne for at dette skulle ske er nede på henholdsvis 0,14 og 0,15 . Men sandsynligheder af denne størrelsesorden kan ikke betragtes som udsagn om signifikante forskelle i forhold til det Rasch-modellen forventer. Sandsynligheden for at de syv første opgaver alle besvares forkert, er til gengæld højsignifikant med en p-værdi på 0,0001, især fordi opgaverne 5-7 alle er relativt lette Det indtryk man får i figur 5.2, er altså velbegrundet. Noget er gået galt i starten af forløbet, og da sværhedsgraderne jo er som de er, må det skyldes at elevens dygtighed ikke kommer til udtryk i svarene på de første opgaver. 
Tabel 5.4 Oplysninger om testforløbet for elev 421613 baseret på 2017-sværhedsgraderne.

\begin{tabular}{|c|c|c|c|c|c|c|c|c|}
\hline \multirow[b]{2}{*}{ itemno } & \multirow[b]{2}{*}{ opgavenummer } & \multicolumn{4}{|c|}{ Betingede sandsynligheder } & \multicolumn{2}{|c|}{ Dygtighedsestimater } & \multirow[b]{2}{*}{ Next } \\
\hline & & score & scoreprob & cumulated & cumulatedprob & WML & SEM & \\
\hline 1 & 01080306061340005-2 & 0 & 0,545 & 0 & 0,5449 & & & \\
\hline 2 & 108030311018 & 0 & 0,705 & 0 & 0,3743 & & & \\
\hline 3 & 01080306061330044-3 & 0 & 0,708 & 0 & 0,2529 & $-2,03$ & 0,79 & $-0,26$ \\
\hline 4 & 010803060613252-4 & 0 & 0,599 & 0 & 0,1370 & $-2,33$ & 0,74 & $-2,37$ \\
\hline 5 & 108030320029 & 0 & 0,142 & 0 & 0,0136 & $-3,59$ & 0,86 & $-2,33$ \\
\hline 6 & 010803060613601-3 & 0 & 0,147 & 0 & 0,0010 & $-4,08$ & 0,79 & $-1,59$ \\
\hline 7 & 1080306061330109 & 0 & 0,270 & 0 & 0,0001 & $-4,23$ & 0,75 & $-1,44$ \\
\hline 8 & 0108030320022-3 & 1 & 0,698 & 1 & 0,0008 & $-3,00$ & 0,90 & $-0,91$ \\
\hline 9 & 108030320040 & 1 & 0,569 & 2 & 0,0046 & $-2,35$ & 0,84 & $-0,78$ \\
\hline 10 & 01080306912-1_2 & 1 & 0,537 & 3 & 0,0180 & $-1,89$ & 0,75 & $-1,46$ \\
\hline 11 & 0108030612006-1 & 1 & 0,702 & 4 & 0,0366 & $-1,63$ & 0,68 & $-1,54$ \\
\hline 12 & 108030320033 & 1 & 0,719 & 5 & 0,0635 & $-1,43$ & 0,63 & $-1,22$ \\
\hline 13 & 1080306061330104 & 1 & 0,648 & 6 & 0,1135 & $-1,25$ & 0,60 & $-0,35$ \\
\hline 14 & 0108030612019-1 & 0 & 0,576 & 6 & 0,0489 & $-1,33$ & 0,58 & $-1,07$ \\
\hline 15 & 01080306061330034-2 & 1 & 0,610 & 7 & 0,1035 & $-1,17$ & 0,55 & $-1,10$ \\
\hline 16 & 108030310373 & 4 & 0,405 & 11 & 0,3325 & $-0,79$ & 0,45 & $-0,93$ \\
\hline 17 & 0108030320069-2 & 1 & 0,575 & 12 & 0,5997 & $-0,71$ & 0,45 & $-1,03$ \\
\hline 18 & 01080303060940011-1 & 1 & 0,600 & 13 & 1,0000 & $-0,63$ & 0,44 & \\
\hline
\end{tabular}

Testforløbet for elev nr. 421613 afsluttes med at elevens dygtighed beregnes til -0,63 med en SEM på 0,44. SEM-værdien er mindre end den bedste SEM, som kunne opnås med 21 dikotome opgaver, hvilket skyldes den ekstra information som den polytome opgave bidrager med.

Vurderingen af elevens dygtighed må nødvendigvis undervurdere hvor dygtig eleven faktisk er, fordi beregningerne inddrager syv opgaver hvor elevens dygtighed ikke er kommet til udtryk. Wright og Stone (1979) som beskrev disse fænomener for næsten 40 år siden, foreslog derfor at dygtigheden skulle genberegnes fraregnet de syv opgaver. Gør man det, ændres estimatet af dygtigheden til 0,93 som er så meget større at det må konkluderes at det første bud på dygtigheden er misvisende i meget alvorlig grad. Konsekvensen er desværre også at SEM baseret på opgave 8-18 forøges til 0,79, og at konklusionen for denne elev må være at testresultatet ikke kan bruges. Estimatet baseret på alle 18 opgaver kan ikke bruges fordi resultatet er vildledende i svær grad, og resultatet baseret på opgave 8-18 kan ikke bruges fordi det er for usikkert.

\subsection{Undersøgelse af udvalgte forløb}

De analyser der er beskrevet i de to foregående afsnit, er foretaget for tilsammen 15 forskellige forløb. Detaljerne i analyserne kan ses i bilag B. Formålet med nærværende afsnit er at sammenfatte resultaterne af analyserne og at diskutere årsager til og konsekvenser af resultaterne.

\subsubsection{Sammenfatning af resultater af analyser af enkeltstående forløb}

Tabel 5.5 præsenterer en oversigt over test af tilpasning mellem enkeltstående testforløb og en Rasch-model med de parametre for sværhedsgrader som blev estimeret i 2017-analysen. 
Tabel 5.5 Resultat af test af tilpasning mellem enkeltstående forløb og Rasch-modellen.

\begin{tabular}{lrrrrl}
\hline & \multicolumn{2}{c}{ Svarvektor } & & \multicolumn{2}{c}{ Mindste $\mathrm{p}$} \\
\cline { 2 - 3 } \cline { 6 - 7 } Elev-id & Betinget sandsynlighed & $\mathrm{p}$ & & Item & Delscore \\
\hline 104649 & 0,000 & 0,489 & & 0,105 & 0,0063 \\
129172 & 0,000 & 0,736 & & 0,186 & 0,005 \\
143590 & 0,003 & 0,838 & & 0,237 & 0,0268 \\
219768 & 0,001 & 0,351 & & 0,110 & 0,0008 \\
259724 & 0,024 & 0,956 & & 0,307 & 0,0237 \\
305503 & 0,021 & 0,760 & & 0,196 & 0,0213 \\
317854 & 0,000 & 0,397 & & 0,187 & 0,0025 \\
341070 & 0,002 & 0,901 & 0,340 & 0,1473 \\
349294 & 0,000 & 0,984 & & 0,230 & 0,0299 \\
386356 & 0,000 & 0,082 & & 0,077 & 0,0005 \\
387213 & 0,111 & 0,793 & & 0,322 & 0,1107 \\
421613 & 0,000 & 0,241 & & 0,142 & 0,0001 \\
428314 & 0,001 & 0,961 & & 0,171 & 0,059 \\
439773 & 0,000 & 0,608 & & 0,080 & 0,0137 \\
441985 & 0,000 & 0,254 & & 0,238 & 0,1567 \\
\hline
\end{tabular}

Note:

Rækkerne er sorteret efter elev-id.

${ }^{1}$ Betinget sandsynlighed er den betingede sandsynlighed for svarmønstret givet den samlede score.

${ }^{2} \mathrm{P}$ er p-værdien for den betingede sandsynlighed.

${ }^{3}$ Mindste $\mathrm{p}$ for items angiver $\mathrm{p}$-værdien for det item der havde den laveste p-værdi.

${ }^{4} \mathrm{P}$-værdien for delscoren er den mindste $\mathrm{p}$-værdi for den kumulerede score.

Tilpasningen til Rasch-modellen blev afvist i 11 ud af 15 tilfælde, i alle tilfælde fordi var tale om perioder med usandsynligt lave eller høje scores.

Tabel 5.6 viser en oversigt over de test vi har gennemført af tilpasning mellem enkeltstående forløb og Rasch-modellen. Tabellen gengiver estimater af elevdygtigheden (WML) og SEM for de enkelte forløb. I de tilfælde hvor tabel 5.5 afslørede problemer med enkelte dele af forløbet, oplyser tabel 5.6 også om estimater og SEM-værdier baseret på den del af forløbet der kan bruges (item-uddrag). Her er gengivet estimater af dygtigheden fraregnet opgaver med fejl i starten hvis antallet af sådanne fejl er signifikant. Endelig fortæller tabellen også om korrelationen mellem de løbende estimater af dygtigheden og den faktiske sværhedsgrad af den næste opgave.

Analysen afslørede fire forløb, hvor der ikke kunne påvises afvigelser mellem forløbene og Rasch-modellens forventninger, samt fire forskellige former for afvigelser fra det, som Rasch-modellen kan acceptere:

1) Seks forløb med for mange fejl i starten.

2) To forløb hvor eleven "står af" efter en i øvrigt god start.

3) To forløb hvor eleven står af efter en god start, men står på igen.

4) Et forløb hvor eleven tydeligt står af til sidst.

To af disse forløb er beskrevet i de foregående afsnit med detaljerede oplysninger om analyserne. De øvrige forløb vil blive beskrevet i det efterfølgende uden detaljerede analyseresultater. Interesserede læsere kan finde disse oplysninger i bilag A og B. 
Tabel 5.6 Oversigt over test af tilpasning mellem enkeltstående forl $ø \mathrm{~b}$ og Rasch-modellen.

\begin{tabular}{|c|c|c|c|c|c|c|c|}
\hline \multirow[b]{2}{*}{ Elev_id } & \multirow[b]{2}{*}{ Score } & \multirow[b]{2}{*}{ Max } & \multicolumn{2}{|c|}{ Alle items } & \multicolumn{2}{|c|}{ Item-uddrag } & \multirow[b]{2}{*}{ Person-item-korrelation } \\
\hline & & & WML & SEM & WML & SEM & \\
\hline 104649 & 15 & 25 & $-0,30$ & 0,43 & 0,32 & 0,56 & 0,69 \\
\hline 129172 & 38 & 61 & 0,46 & 0,28 & 0,70 & 0,30 & 0,73 \\
\hline 143590 & 14 & 19 & 0,54 & 0,55 & 1,33 & 0,74 & 0,67 \\
\hline 219768 & 5 & 15 & 2,10 & 0,61 & $-0,11$ & 0,68 & 0,71 \\
\hline 259724 & 6 & 10 & 0,08 & 0,69 & & & 0,67 \\
\hline 305503 & 3 & 11 & 0,19 & 0,72 & $-1,62$ & 0,71 & 0,79 \\
\hline 317854 & 15 & 32 & 1,56 & 0,38 & & & 0,64 \\
\hline 341070 & 9 & 17 & 2,36 & 0,54 & & & 0,65 \\
\hline 349294 & 13 & 21 & $-0,33$ & 0,44 & 0,20 & 0,56 & 0,71 \\
\hline 386356 & 6 & 22 & $-0,71$ & 0,52 & $-1,57$ & 0,66 & 0,80 \\
\hline 387213 & 4 & 10 & 2,03 & 0,76 & & & 0,86 \\
\hline 421613 & 13 & 21 & $-0,63$ & 0,44 & 0,93 & 0,79 & 0,64 \\
\hline 428314 & 18 & 25 & 0,79 & 0,51 & & & 0,86 \\
\hline 439773 & 9 & 23 & 1,70 & 0,47 & 1,17 & 0,56 & 0,78 \\
\hline 441985 & 9 & 17 & 1,88 & 0,51 & & & 0,59 \\
\hline
\end{tabular}

Note:

Rækkerne er sorteret efter elev-id.

${ }^{1}$ Score: Samlet score for eleven.

${ }^{2}$ Max: Den maksimale score i det givne forløb.

${ }^{3}$ Alle items, WML og SEM: Estimat og usikkerhed på estimatet af elevens dygtighed for hele forløbet.

${ }^{4}$ Item-uddrag, WML og SEM: Estimat og usikkerhed på estimatet af elevens dygtighed for den del af forløbet som ikke har udvist tegn på fejl. 


\subsubsection{Forløb, hvor der ikke kan påvises afvigelser fra Rasch-modellens forventninger}
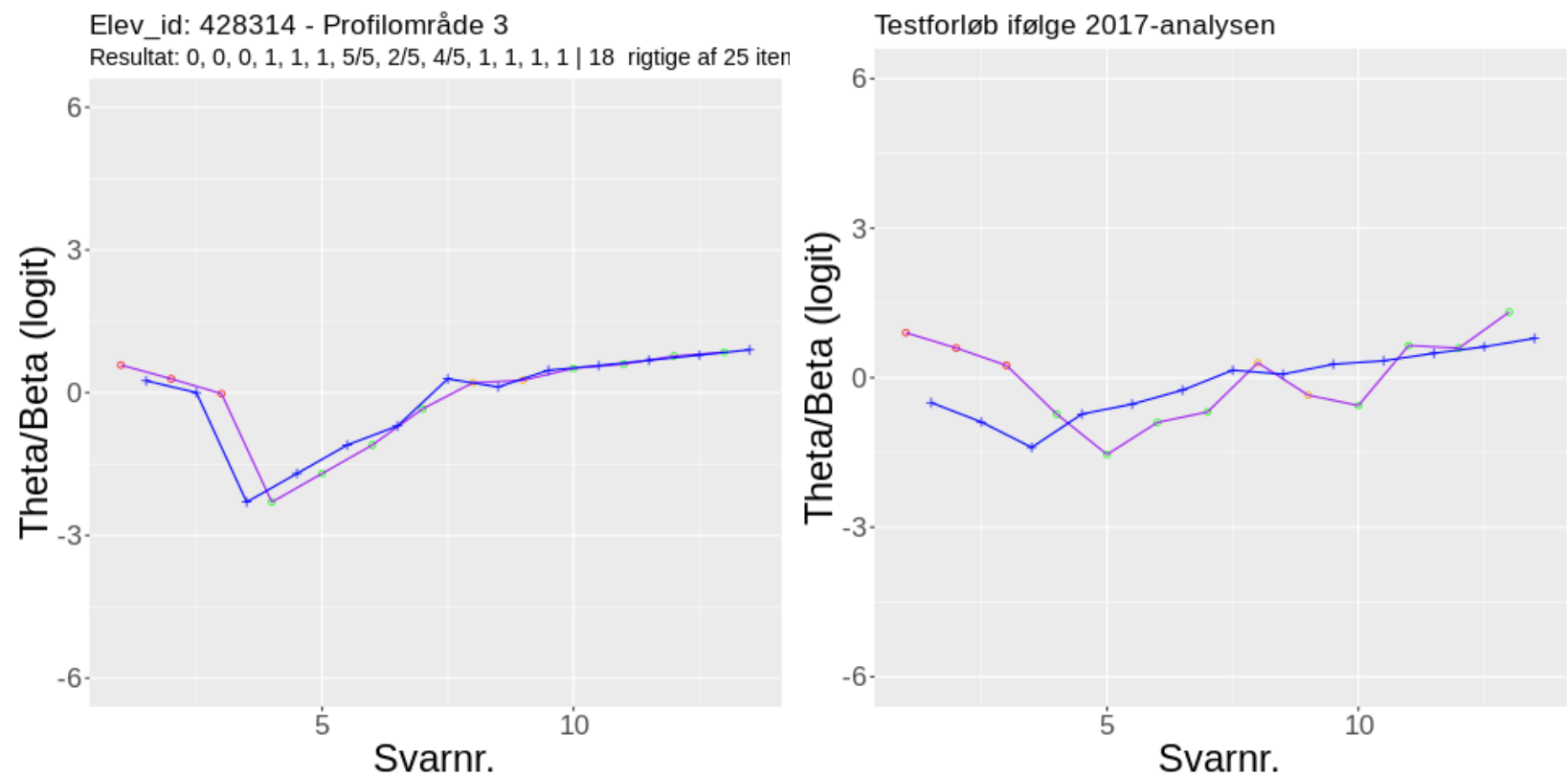

Figur 5.3 Testforløb for elev 428314, profilområde 3. Se forklaring i figur 5.1.

Elev 428314 svarer som det fremgår af figur 5.3, først tre forkerte, et antal som lige netop ikke er signifikant $(\mathrm{p}=0.05)$, dernæst svarer hun rigtigt på 18 af 22 spørgsmål. Tre ud af 13 opgaver er polytome, hvilket bidrager til at få SEM ned på 0,51. Mon hun kunne have klaret udfordringen fra sværere spørgsmål og derved have fået et bedre resultat?

Elev_id: 387213 - Profilområde 3

Resultat: $1,1,1,1,0,0,0,0,0,0 \mid 4$ rigtige af 10 items.

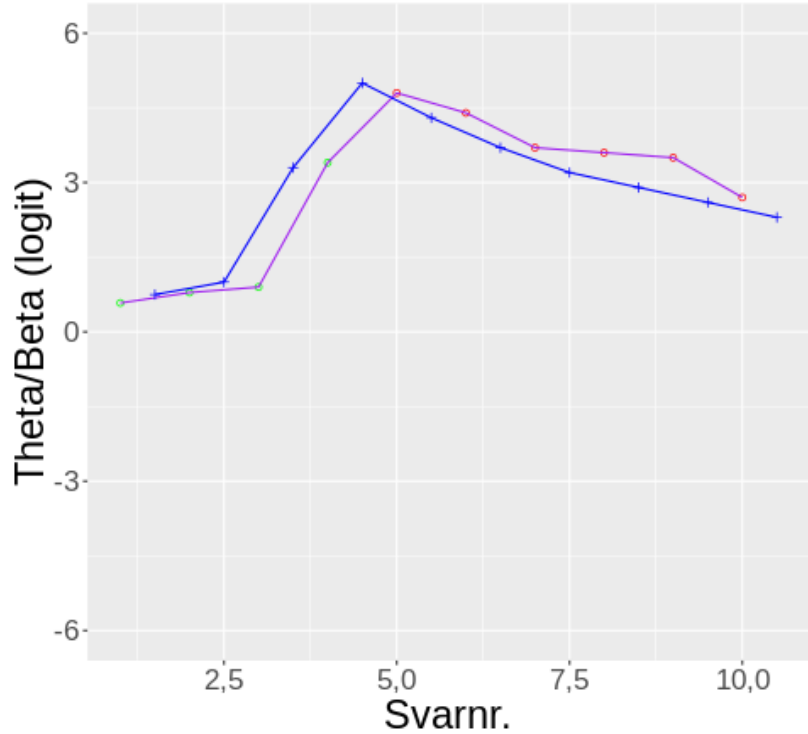

Testforløb ifølge 2017-analysen

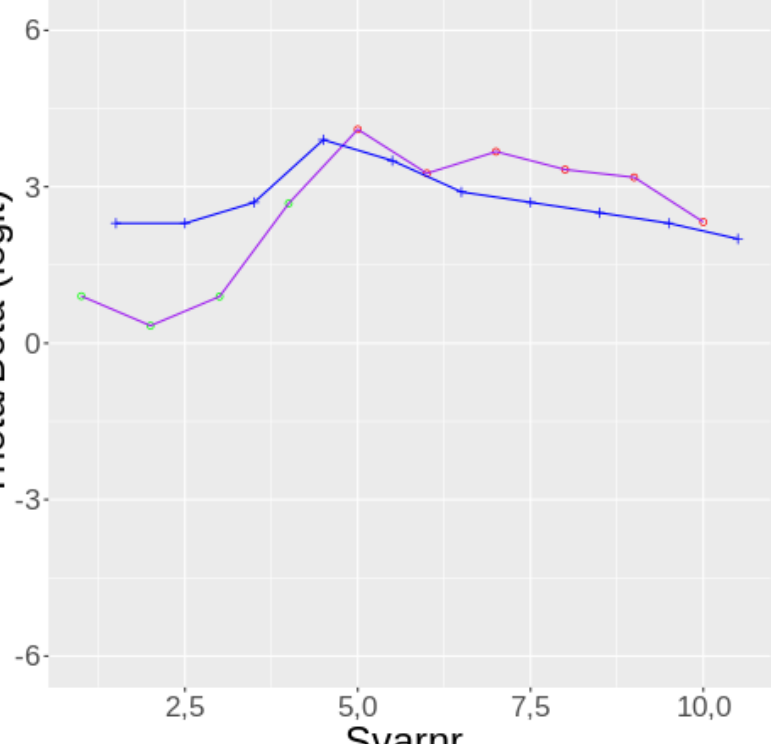

Figur 5.4 Testforløb for elev 387213, profilområde 3. Se forklaring i figur 5.1. 
Som det fremgår af figur 5.4, lægger elev 387213 i tekstforståelsesprofilområdet ud med fire korrekt besvarede opgaver hvorefter hun tilsyneladende står af. I forhold til det afsluttende mål for dygtigheden er opgaverne lige i overkanten af hvad eleven burde klare. På trods af serien af forkerte svar ender hun omkring den 90. percentil. Der er derfor intet der kan tages som belæg for at eleven er stået af efter fjerde opgave. Da der kun er besvaret ti opgaver som rammer lidt ved siden af eleven, er SEM for denne elev på 0,76. Uanset at tilpasningen til Rasch-modellen ikke kan forkastes, burde dette testresultat være afvist. Det er simpelthen for usikkert. Denne elevs forløb er et eksempel på at der ingen lid kan fæstes til resultatet på grund af den meget høje SEM, og det adaptive system burde derfor have markeret over for læreren at dette resultat ikke bør bruges.
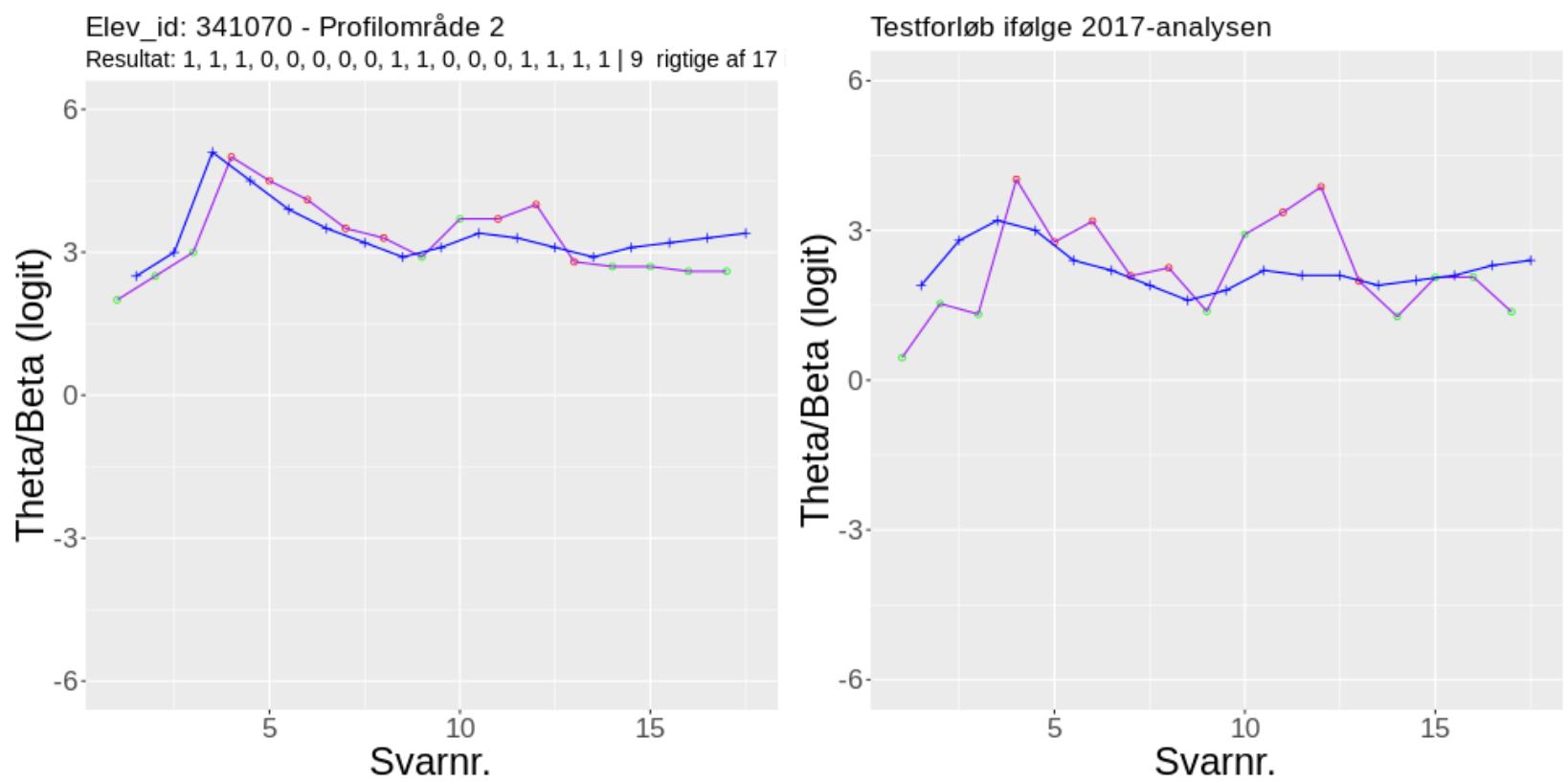

Figur 5.5 Testforløb for elev 341070, profilområde 2. Se forklaring i figur 5.1.

Elev 341070's forløb i profilområdet afkodning er karakteriseret ved klumper, se figur 5.5. Tre korrekte, fem fejl, to korrekte, tre fejl og fire korrekte. Det ser påfaldende ud, men tallene i sig selv kan ikke afvise tilpasning mellem responser og model. Sådan kan testresultater se ud, uden at der er noget galt.

Denne elevs forløb har præcis samme mønster som elev 317854, figur 5.11, i de første 17 opgaver, men hvor elev 341070 stopper efter 17 svar, får 317854 får lov at fortsæette med yderligere 15 spørgsmål. Det resulterer i helt forskellige resultater for de to elever. 


\subsubsection{Forløb med dårlig start}
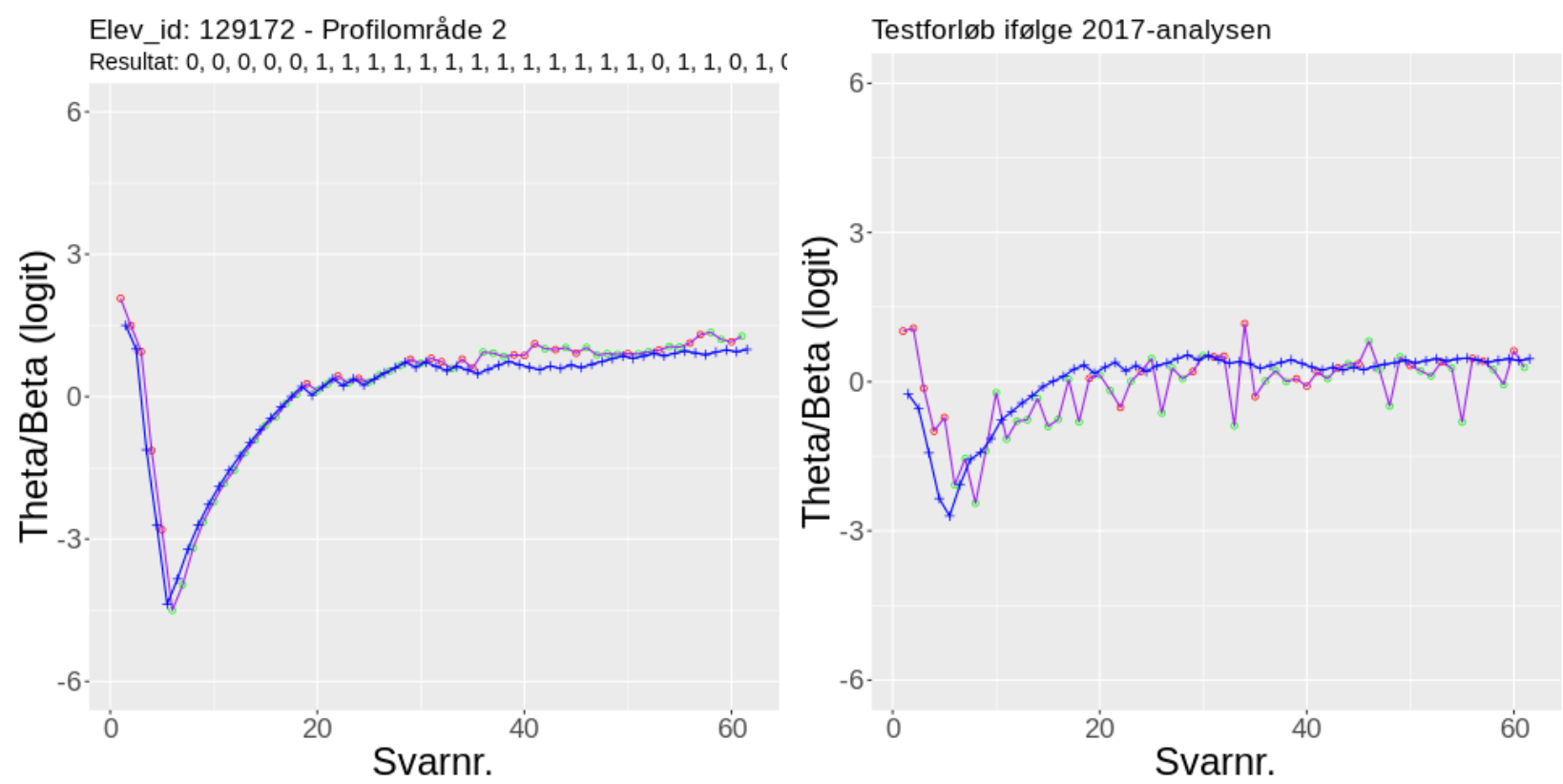

Figur 5.6 Testforløb for elev 129172, profilområde 2. Se forklaring i figur 5.1.

Elev 129172 lægger ud med 5 forkerte svar, heraf tre som eleven ikke burde have vanskeligheder med, se figur 5.6. Derefter ser forløbet ud til at passe meget flot til Rasch-modellen. Da der besvares 61 opgaver, kommer SEM ned på 0,27. Hvis man udelader de første fem opgaver forbedres estimatet af dygtigheden fra 0,46 til 0,70 med en SEM på 0,30 .

Dette er et eksempel på et forløb med tilstrækkelig mange opgaver til at producere relativt sikre målinger, og hvor en justering der korrigerer for den dårlige start, ikke forringer målingerne. Det er faktisk det eneste af de 15 eksempler hvor vi kan konkludere på denne måde. 

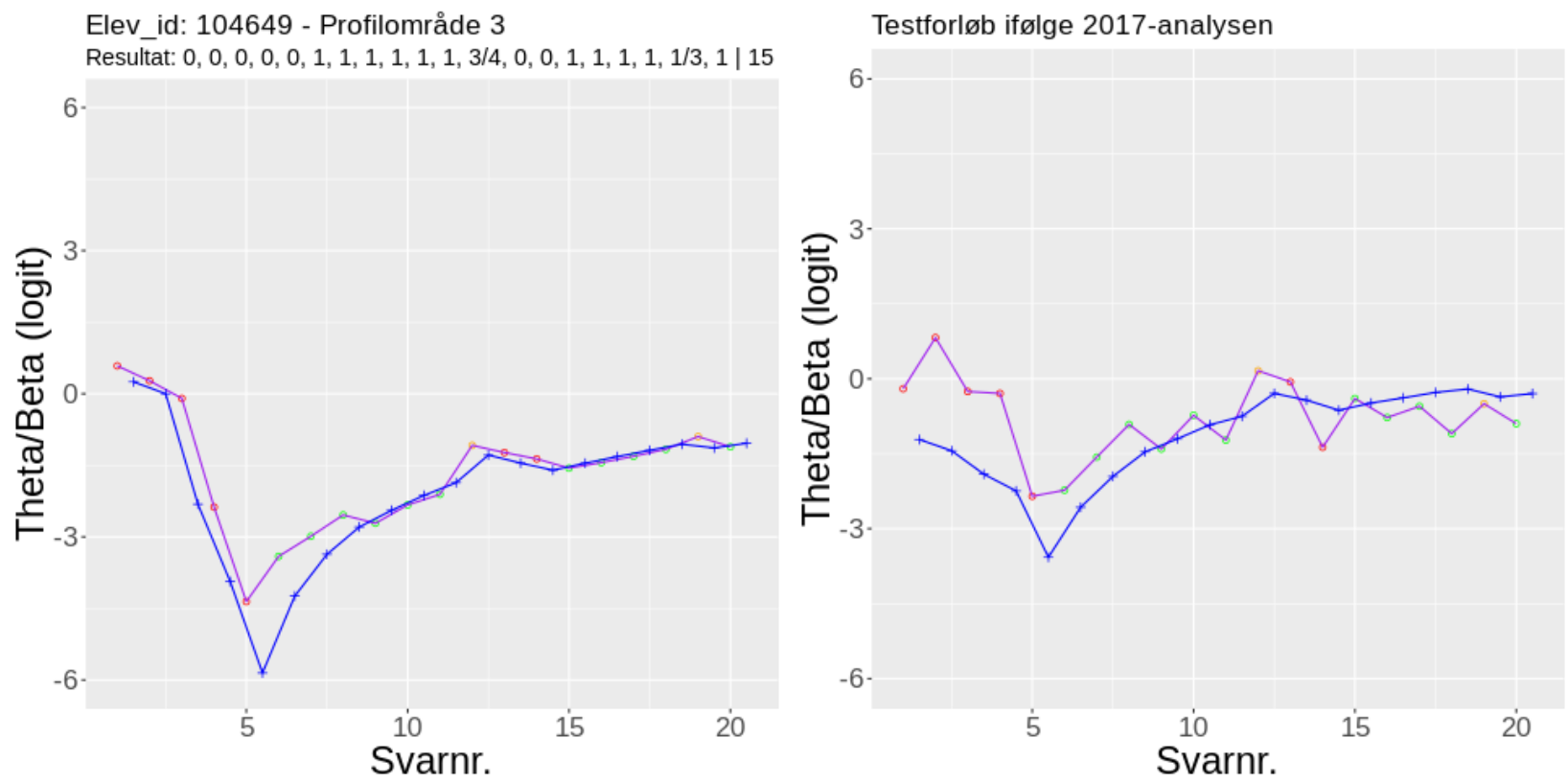

Figur 5.7 Testforløb for elev 104649, profilområde 3. Se forklaring i figur 5.1.

Elev 104649, figur 5.7, lægger også ud med fem forkerte svar, dernæst ni rigtige (heraf tre i et partial credititem)), tre forkerte (heraf et $i$ et partial credit item) og fem rigtige (ét i et partial credit-item). Kurven flader ud undervejs i den lange række af rigtige. En hypotese kunne være at nationale tests algoritme på grund af et for lavt estimat stiller for lette opgaver og derved ikke giver eleven mulighed for at opveje den uheldige start. Hvis de første fem opgaver udelades af beregningerne, stiger dygtigheden fra -0,30 til 0,32 og SEM fra 0,43 til 0,56 .

Elev_id: 349294 - Profilområde 3

Resultat: $0,0,0,0,1,1,1,1,1,1,2 / 3,1,1,1,2 / 5 \mid 13$ rigtige af 21

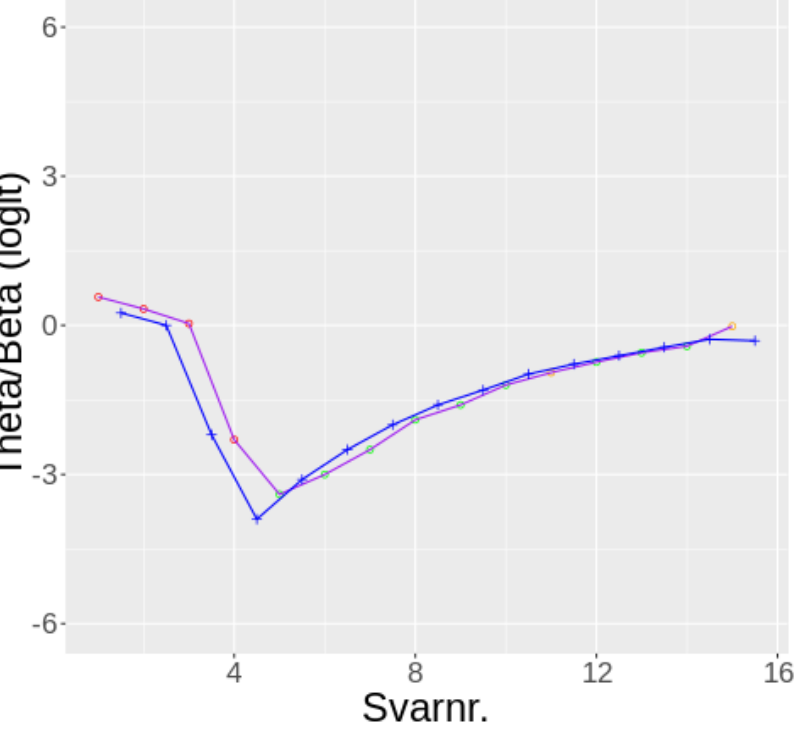

Testforløb ifølge 2017-analysen

6 -

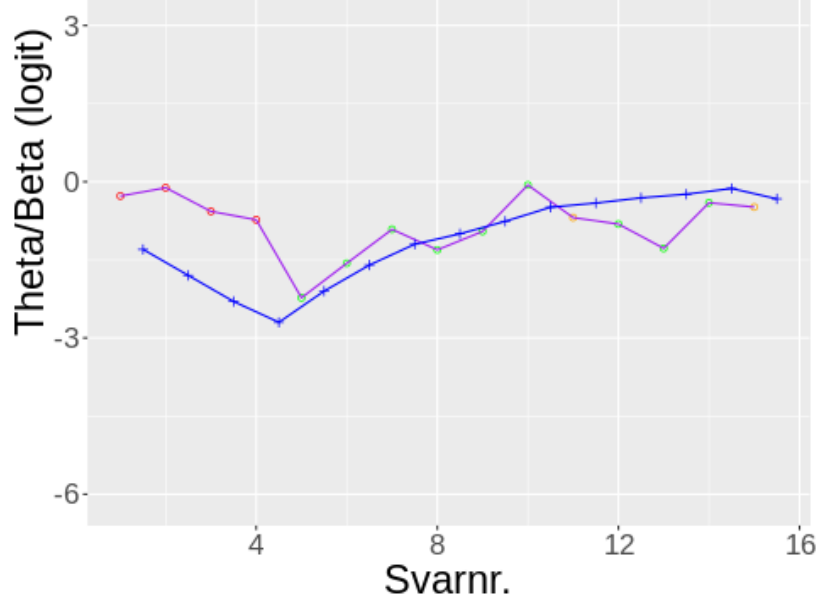

Figur 5.8 Testforløb for elev 349294, profilområde 3. Se forklaring i figur 5.1. 
Elev 349294 lægger ud med fire forkerte svar, se figur 5.8. Derefter svarer hun rigtigt på 13 af 17 items. Afvigelsen fra Rasch-modellen er kun svagt signifikant $(\mathrm{p}=0,030)$. Hvis de første fire opgaver udelades af beregningerne, stiger dygtigheden fra -0,33 til 0,20 og SEM fra 0,44 til 0,56. Ville hun have fortsat den lange stribe af korrekte svar hvis hun havde fået lov at fortsætte?
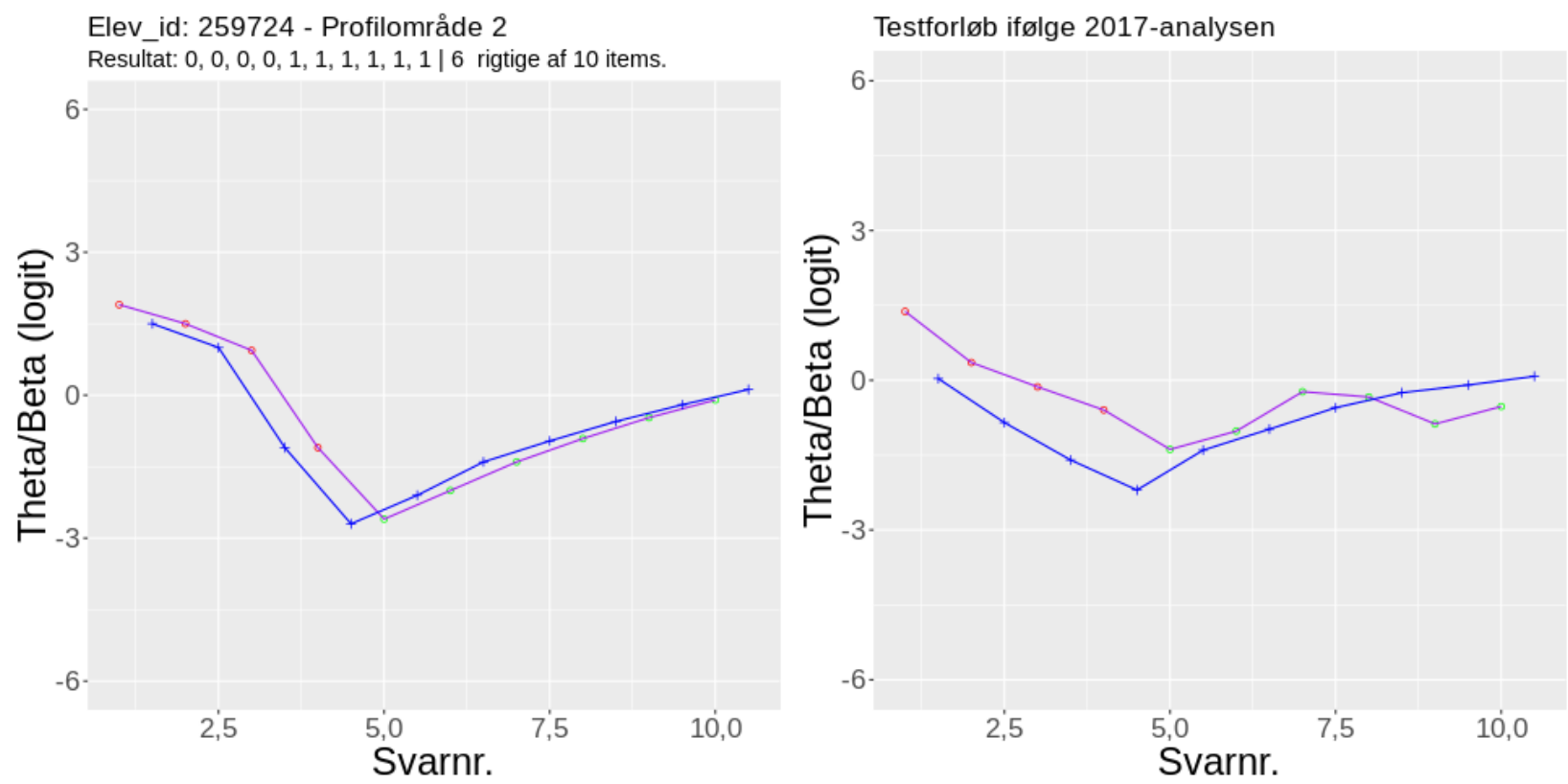

Figur 5.9 Testforløb for elev 259724, profilområde 2

Elev 259724, se figur 5.9, er meget længe om at svare på hver enkelt opgave, se tabel A.9. Dette forløb starter også med fire fejl, men er herefter fejlfrit. Ville hun have fortsat sin stribe af rigtige hvis hun havde fået lov at fortsætte? Afvigelsen fra Rasch-modellen er kun svagt signifikant ( $\mathrm{p}=0,023)$. Der er kun besvaret 10 opgaver, som - hvis de alle inkluderes - giver en SEM på 0,69. Dette testresultat bør forkastes med og uden de indledende opgaver. Usikkerheden er så stor, at resultatet er ubrugeligt. 

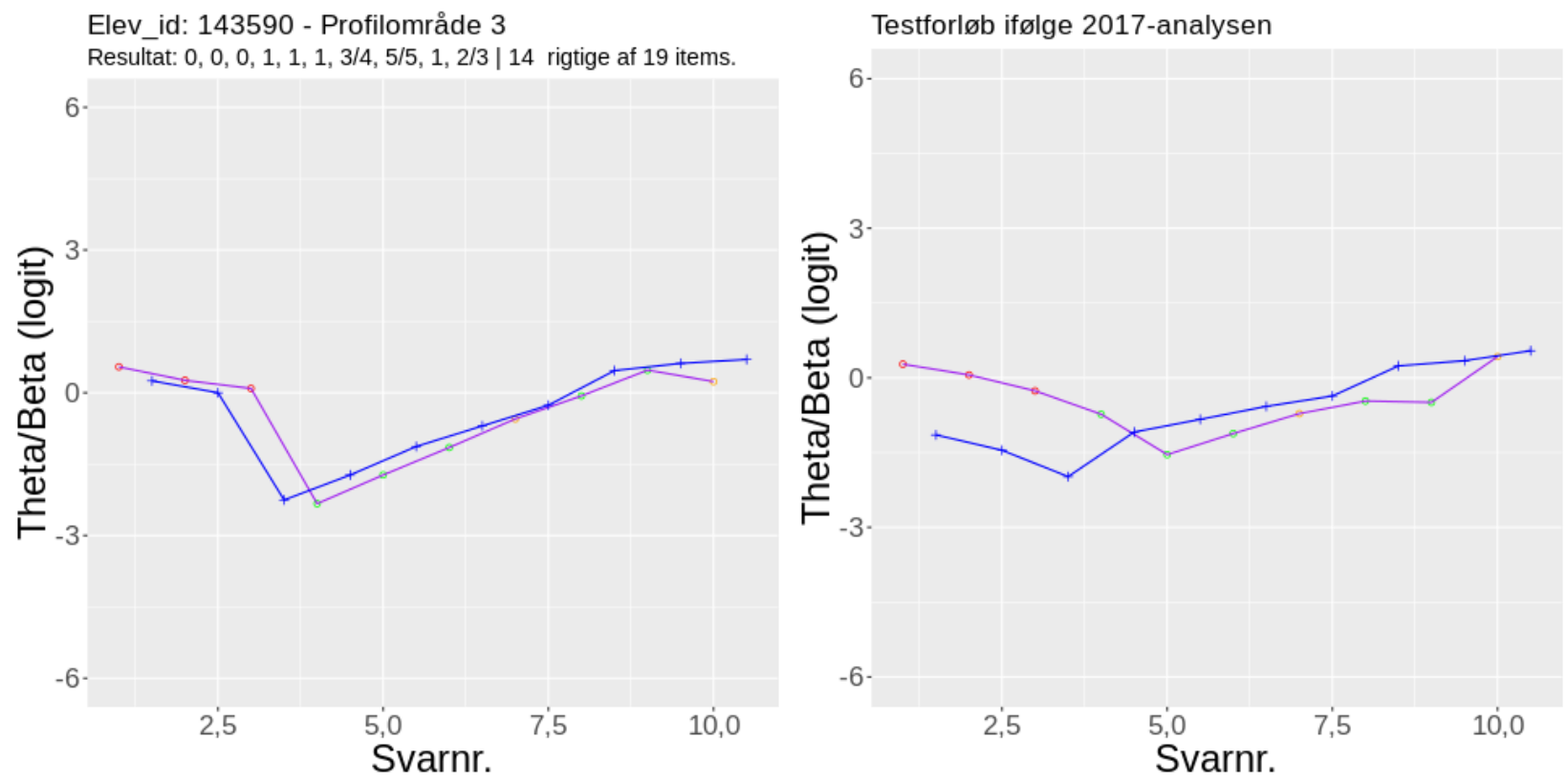

Figur 5.10 Testforløb for elev 143590, profilområde 3. Se forklaring i figur 5.1.

Elev 143590 starter sit forløb i tekstforståelse med tre fejl, se figur 5.10. Dernæst svarer hun rigtigt på 14 og forkert på to delspørgsmål. På trods af næsten tre gange så mange rigtige som forkerte, når hun kun lige op over hvor hun startede. Problemet med dette forløb er at eleven indledningsvist svarer forkert på opgaver som hun ifølge det endelige estimat burde have kunnet svare rigtigt på, men da hun så begynder at svare rigtigt, er opgaverne for lette, og hun kan ikke trække sit resultat langt nok op efter ti opgaver.

Ville eleven kunne have fortsat sin lange række af rigtige svar hvis hun havde fået mere tid? Afvigelsen fra Rasch-modellen er kun svagt signifikant $(\mathrm{p}=0,027)$. Hvis de første tre opgaver udelades af beregningerne, stiger dygtigheden fra 0,54 til 1,33 og SEM fra 0,55 til 0,74 hvilket er langt fra det tilladelige. Dette forløb bør også forkastes selvom man kan korrigere for den usikre start.

\subsubsection{Forløb med dårlig slutning}

De følgende forløb stammer fra elever som starter med flere korrekte svar, men dernæst går over til at svare forkert. 
Elev_id: 317854 - Profilområde 2 Resultat: 1, 1, 1, 0, 0, 0, 0, 0, 1, 1, 0, 0, 0, 1, 1, 1, 1, 0, 1, 0, 1, 1, 1, c

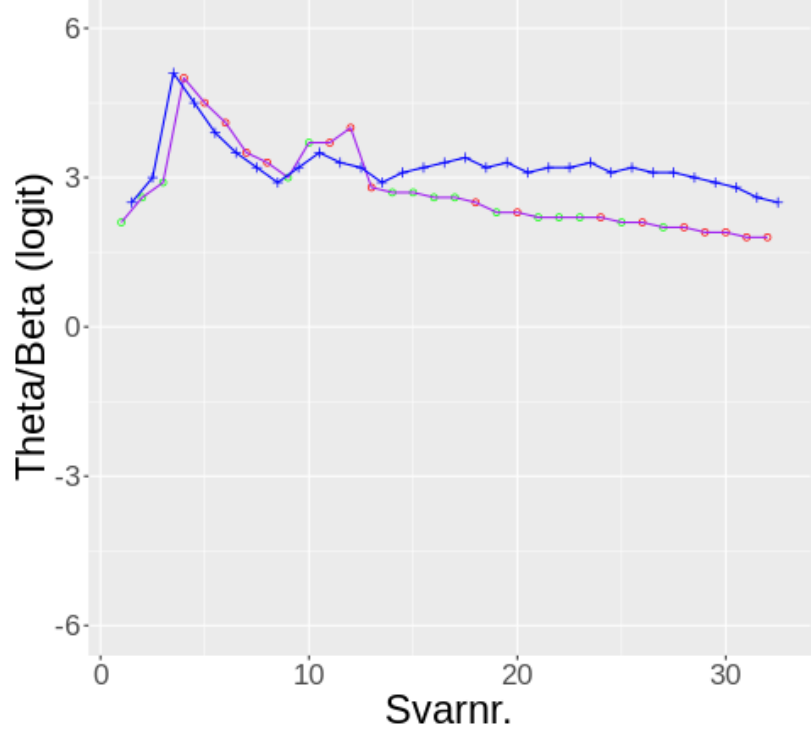

Testforløb ifølge 2017-analysen

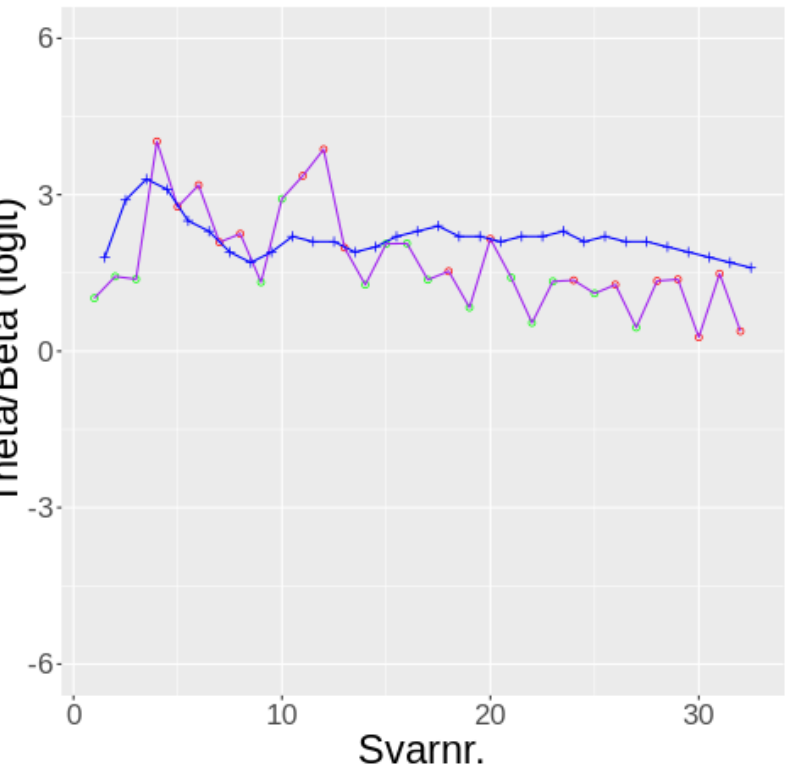

Figur 5.11 Testforløb for elev 317854, profilområde 2. Se forklaring i figur 5.1.

Eleven 317854, se figur 5.11, har i de første 17 opgaver i profilområdet afkodning nøjagtig det samme svarmønster som elev 341070, se figur 5.5, men får lov at fortsætte med yderligere 15 spørgsmål. Det resulterer i et væsentligt dårligere resulat omkring den 55 . percentil.

Eleven slutter af med fem fejl på opgaver hvor eleven har mere end en fair chance for at svare rigtigt. Undervejs er der dog andre variationer med klumper af svar der passer ret dårligt til sværhedsgraderne. Vores vurdering er at der enten er tale om en ujævn præstation hvor indsatsen fra elevens side varierer, eller hvor der er typer af opgaver som eleven har problemer med. Uden adgang til indholdet af opgaverne og uden mulighed for at tale med eleven kan vi blot konkludere at slutresultatet formodentlig undervurderer elevens dygtighed. Bemærk i tabel A.11, at eleven har stoppet forløbet undervejs og genoptaget det seks dage senere. 

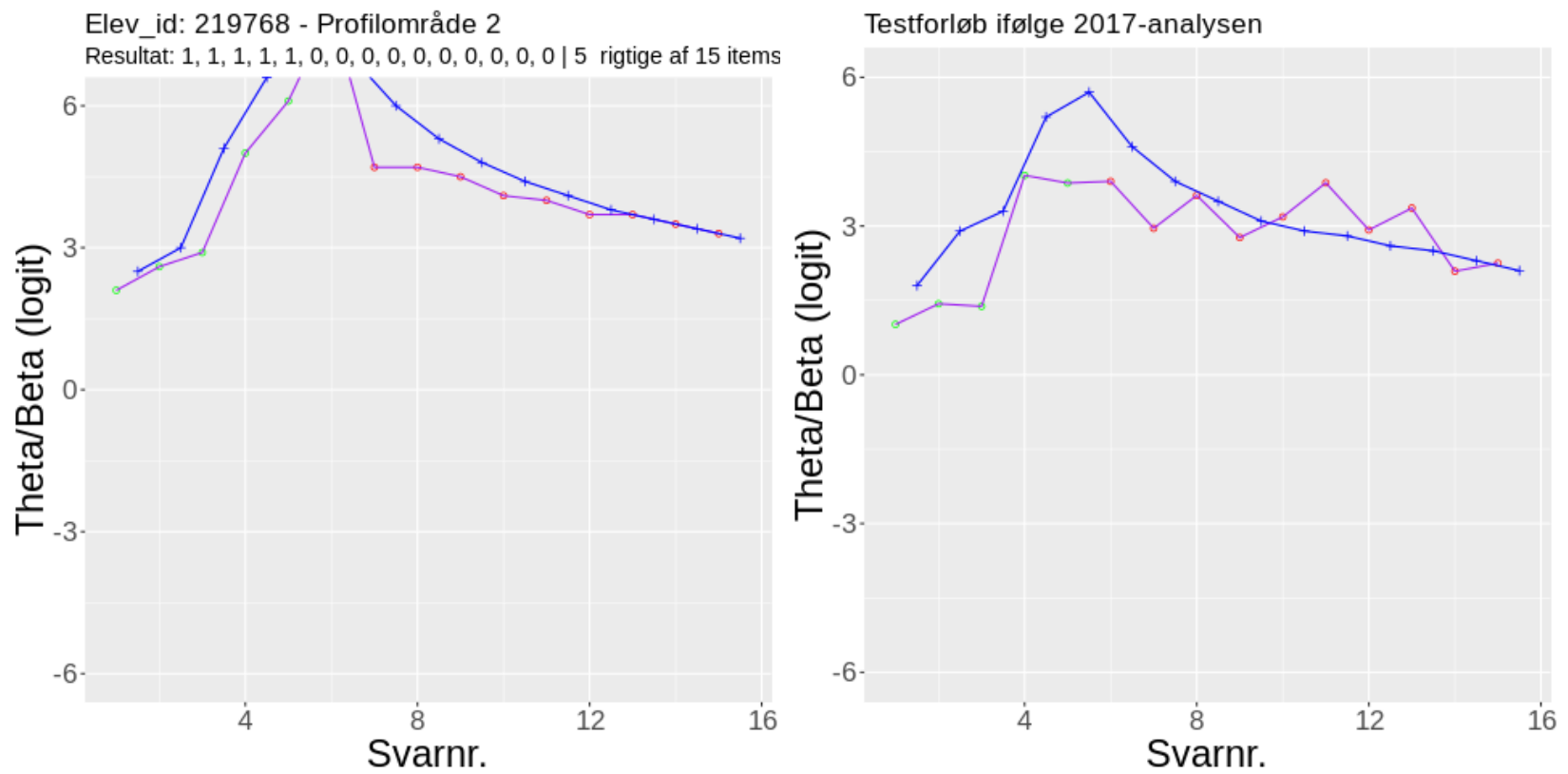

Figur 5.12 Testforløb for elev 219768, profilområde 2. Se forklaring i figur 5.1.

Elev 219768, se figur 5.12, lægger ud med at svare rigtigt på fem spørgsmål. De resterende ti svarer hun forkert på. De mange korrekte betyder naturligvis at den adaptive algoritme herefter vælger meget vanskelige opgaver, men dette er ikke nok til at forklare at der ikke forekommer en eneste korrekt opgave i de sidste ti opgaver. Forløbet afviger højsignifikant fra Rasch-modellens forventninger, og fem rigtige ud af 15 opgaver i en adaptiv test fortæller i sig selv at resultatet ikke kan bruges.

Hvad ville der ske hvis eleven havde fået yderligere 10 spørgsmål, måske nogle lettere spørgsmål? Ville hun også have svaret forkert på dem? Dette er et eksempel på hvor vigtigt det er at svare rigtigt på de første spørgsmål. 
Elev_id: 305503 - Profilområde 3 Resultat: $1,1,1,0,0,0,0,0,0,0,0 \mid 3$ rigtige af 11 items.

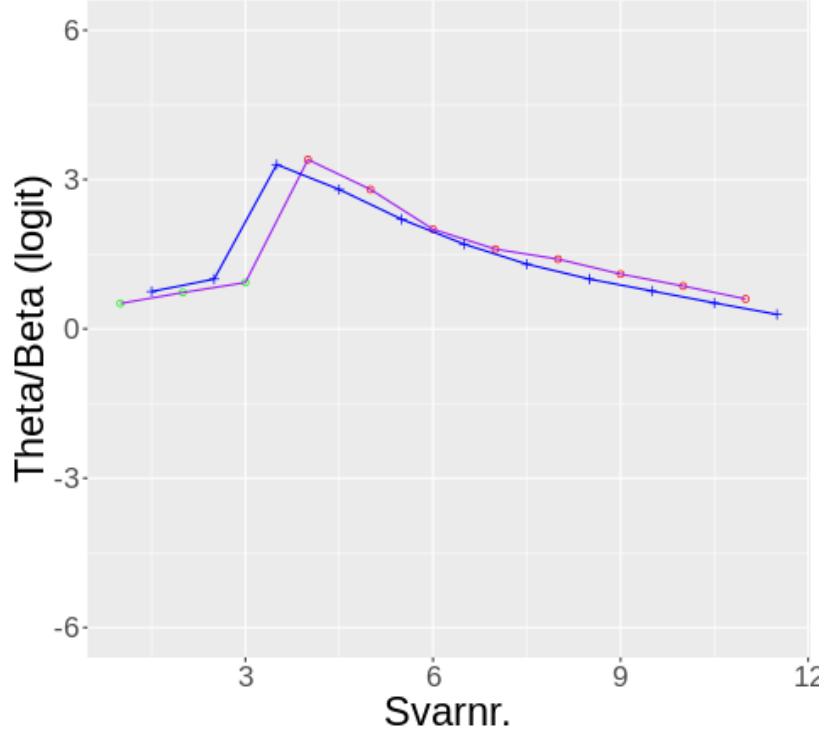

Testforløb ifølge 2017-analysen

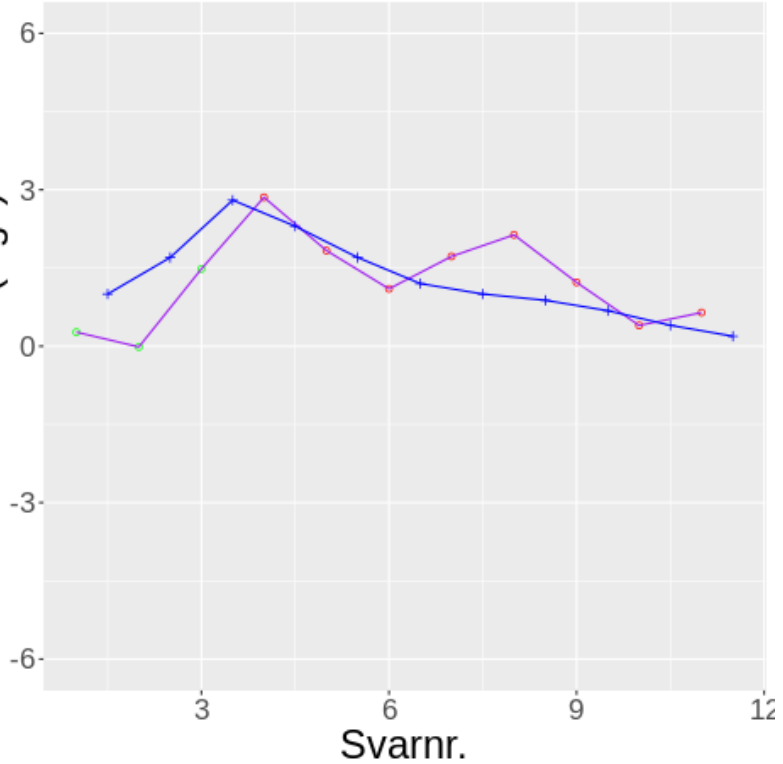

Figur 5.13 Testforløb for elev 305503, profilområde 3. Se forklaring i figur 5.1.

Elev 305503 svarer rigtigt på tre spørgsmål og dernæst forkert på otte hvorefter hun stoppes, se figur 5.13. De indledende korrekte svar betyder naturligvis at den adaptive algoritme herefter vælger meget vanskelige opgaver, men dette er ikke helt nok til at forklare at der ikke forekommer en eneste korrekt opgave i de sidste otte opgaver. Forløbet afviger svagt signifikant fra Rasch-modellens forventninger, og tre rigtige ud af 11 opgaver i en adaptiv test signalerer også at resultatet ikke kan bruges. Beregningerne slutter i øvrigt med en SEM på 0,72. Alene af den grund burde resultatet være forkastet. 


\subsubsection{Forløb med rigtige, så forkerte og så rigtige igen}
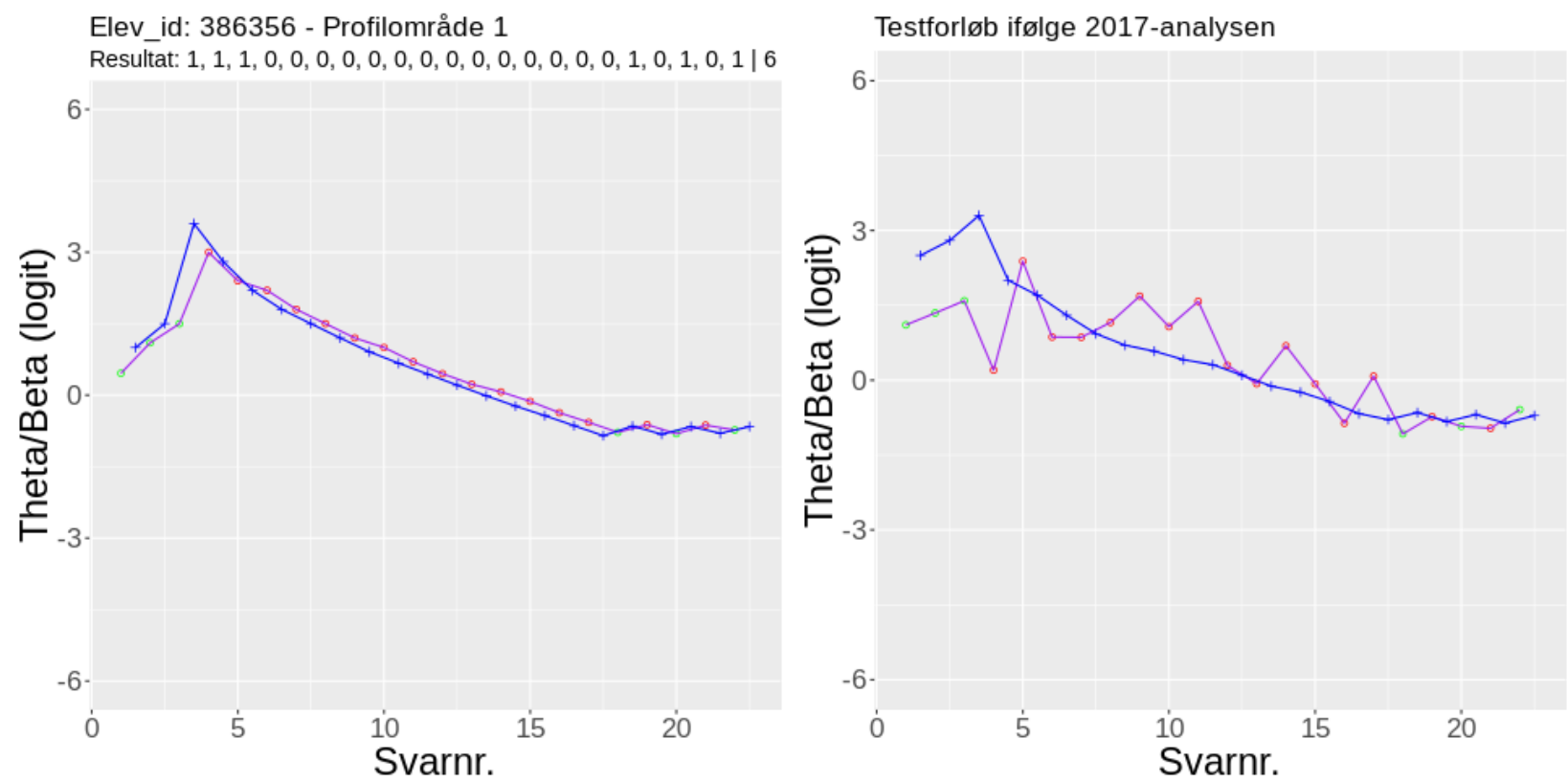

Figur 5.14 Testforløb for elev 386356, profilområde 1. Se forklaring i figur 5.1.
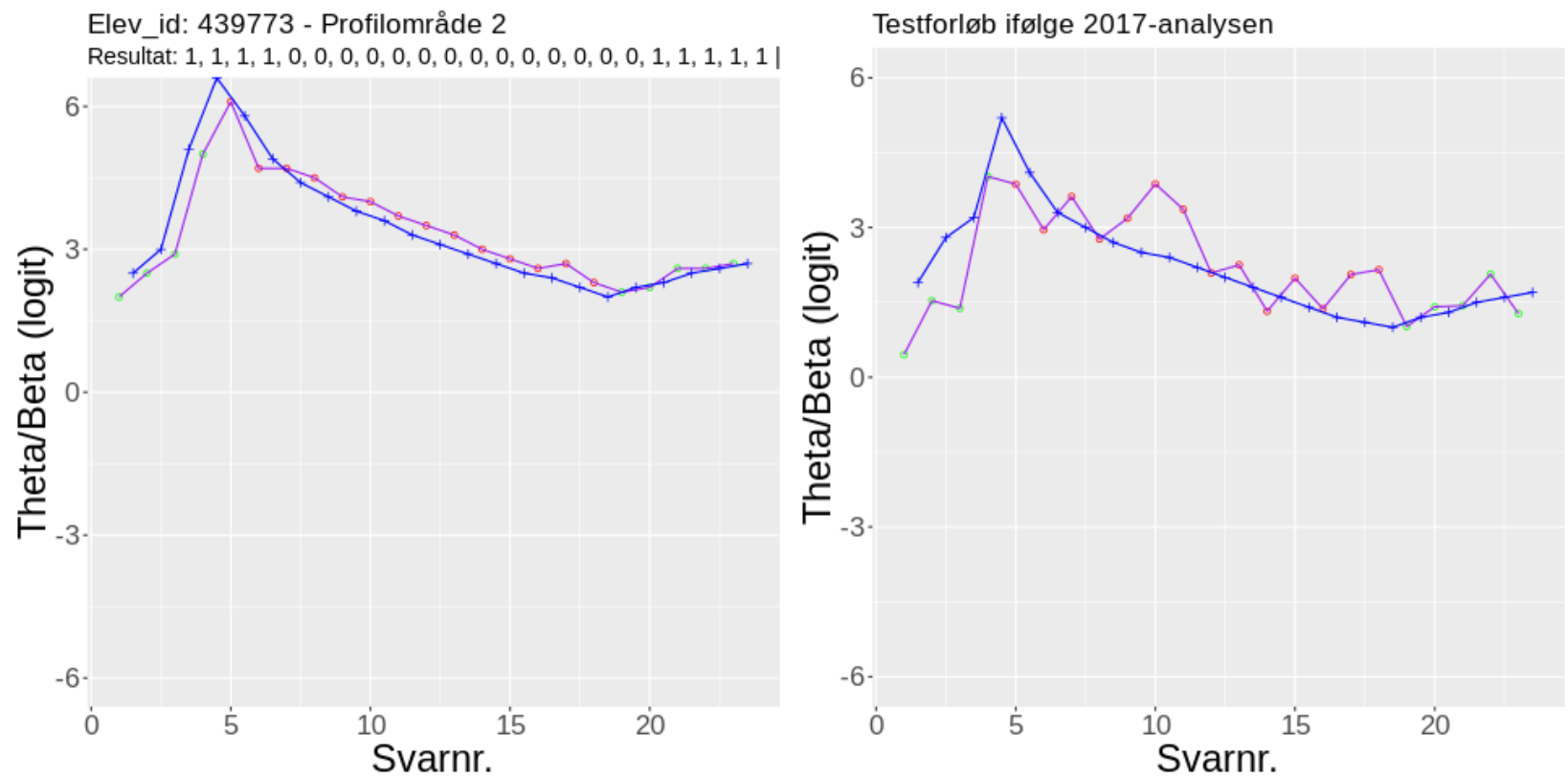

Figur 5.15 Testforløb for elev 439773, profilområde 2. Se forklaring i figur 5.1.

Elev 386356, se figur 5.14, indleder i profilområdet sprogforståelse med tre korrekte svar og svarer dernæst forkert på 14 spørgsmål og så rigtigt på tre spørgsmål og forkert på fem spørgsmål. Af naturlige grunde vælger det adaptive system fem meget lette opgaver til sidst, men det er ikke nok til at bortforklare at 
Tabel 5.7 Percentil- og logitplacering af de undersøgte elevers resultater.

\begin{tabular}{|c|c|c|c|c|c|}
\hline \multirow[b]{2}{*}{ Elev_id } & \multirow[b]{2}{*}{ Profilområde } & \multicolumn{2}{|c|}{ Percentiler } & \multicolumn{2}{|c|}{ Logit } \\
\hline & & DNT-analysen & 2017-analysen & DNT-analysen & 2017-analysen \\
\hline 104649 & 3 & $5 \%$ & $16 \%$ & $-1,037$ & $-0,297$ \\
\hline 129172 & 2 & $15 \%$ & $19 \%$ & 0,993 & 0,460 \\
\hline 143590 & 3 & $42 \%$ & $45 \%$ & 0,700 & 0,543 \\
\hline 219768 & 2 & $80 \%$ & $77 \%$ & 3,195 & 2,099 \\
\hline 259724 & 2 & $6 \%$ & $11 \%$ & 0,115 & 0,078 \\
\hline 305503 & 3 & $24 \%$ & $32 \%$ & 0,286 & 0,192 \\
\hline 317854 & 2 & $56 \%$ & $57 \%$ & 2,549 & 1,556 \\
\hline 341070 & 2 & $85 \%$ & $85 \%$ & 3,392 & 2,361 \\
\hline 349294 & 3 & $10 \%$ & $15 \%$ & $-0,310$ & $-0,334$ \\
\hline 386356 & 1 & $19 \%$ & $23 \%$ & $-0,661$ & $-0,708$ \\
\hline 387213 & 3 & $88 \%$ & $91 \%$ & 2,321 & 2,027 \\
\hline 421613 & 3 & $4 \%$ & $9 \%$ & $-1,556$ & $-0,631$ \\
\hline 428314 & 3 & $50 \%$ & $54 \%$ & 0,896 & 0,788 \\
\hline 439773 & 2 & $63 \%$ & $62 \%$ & 2,731 & 1,698 \\
\hline 441985 & 2 & $70 \%$ & $69 \%$ & 2,891 & 1,883 \\
\hline
\end{tabular}

Note:

Percentiler er for begge analysers vedkommende beregnet på baggrund af fordelingen af elevdygtighederne i 2017 (og er altså ikke de historiske percentiler som DNT rapporterer til lærerne).

der er noget der ikke passer. I lyset af at eleven laver så mange fejl er tre rigtige på de første tre opgaver klart signifikant $(\mathrm{p}=0.00048)$. Seks korrekte ud af 22 opgaver er også alt for lidt $\mathrm{i}$ en adaptiv test selvom nationale tests algoritmes valg af nye opgaver ikke svarer perfekt til opgavernes sande sværhedsgrader. Dette testresultat er klart uanvendeligt. Bemærk at de 6 sidste spørgsmål i testen kun er stillet inden for dette profilområde, se tabel A.14, så algoritmen har ikke været sikker på estimatet før den 22. opgave i dette profilområde.

Fire rigtige svar i profilområdet afkodning bringer elev 439773 meget højt op, se figur 5.15. De følgende 11-12 forkerte får hende tilbage hvor hun startede. En slutspurt med fem rigtige til sidst opvejer de foregående fem forkerte svar. Eleven har siddet ved testen i to timer og et kvarter. Variationerne kan igen til dels forklares ved at der kommer mange vanskelige opgaver efter den gode start og mange lette opgaver til sidst på grund af de mange fejl, men variationerne er svagt signifikante $(\mathrm{p}=0,013)$.

\subsection{Afsluttende kommentarer til analyserne}

Målet med en adaptiv algoritme er at give eleven opgaver som passer til elevens niveau. Man har valgt at lade algorimten starte med at give opgaver på samme niveau til alle elever, og derfor må man forvente at mange elever svarer forkert eller rigtigt på et antal opgaver i starten, indtil algoritmen har fundet et passende estimat af elevens dygtighed. Det er svært at afgøre præcis hvor mange opgaver det vil være rimeligt at forvente at et større antal elever svarer forkert/rigtigt på i træk. I tabel 5.8 har vi angivet hvor mange elever der starter med at svare konsekvent rigtigt eller forkert på op til ti opgaver i træk.

Knap 7 procent af alle testforløb (9.509 testforløb (hver elev gennemfører tre testforløb)) indeholder enten fire forkerte svar eller fire korrekte svar på opgaver i træk i starten af forløbet. Et ikke ubetydeligt antal 
Tabel 5.8 Antal elever der svarer konsekvent rigtigt eller forkert i starten af forløbet

\begin{tabular}{|c|c|c|c|c|c|c|}
\hline \multirow[b]{2}{*}{ Antal fejl/korrekt i træk } & \multicolumn{3}{|c|}{ Svarer forkert } & \multicolumn{3}{|c|}{ Svarer korrekt } \\
\hline & Profilområde 1 & Profilområde 2 & Profilområde 3 & Profilområde 1 & Profilområde 2 & Profilområde 3 \\
\hline 2 & 13989 & 9689 & 7652 & 8052 & 15124 & 18262 \\
\hline 3 & 6548 & 3855 & 3254 & 3575 & 9541 & 10634 \\
\hline 4 & 1179 & 848 & 1275 & 2419 & 1449 & 2339 \\
\hline 5 & 199 & 262 & 193 & 865 & 413 & 262 \\
\hline 6 & 94 & 85 & 94 & 626 & 179 & 38 \\
\hline 7 & 49 & 31 & 64 & 534 & 151 & 11 \\
\hline 8 & 40 & 27 & 55 & 473 & 104 & 7 \\
\hline 9 & 38 & 24 & 51 & 241 & 84 & 1 \\
\hline 10 & 35 & 21 & 47 & 224 & 69 & 1 \\
\hline
\end{tabular}

Note:

Tallene angiver hvor mange elever der har svaret korrekt på antallet af opgaver i træk. Tallene indeholder også elever der har svaret mere end det givne antal korrekt.

elever svarer også forkert eller rigtigt på fem eller flere opgaver i træk i starten af et af profilområderne. Det er med andre ord store andele af eleverne som ikke oplever en adaptiv test i væsentlige dele af forløbet.

Gennemgangen af testforløb har også vist at det at acceptere en SEM på 0,55 er alt for usikkert, og under alle omstændigheder bør ingen forløb med endnu højere SEM rapporteres til lærere, forældre eller andre (det fremgik i kapitel 4 at omkring 12-16 procent af forløbene resulterer i en SEM højere end 0,55 i alle tre profilområder).

Det vil altid være tilfældet i pædagogiske test at der er elever som ikke svarer i overensstemmelse med hvad man kan forvente givet den estimerede dygtighed. En rimelig konsekvens af dette vil være at elever som udviser uventet testadfærd, identificeres, og at det meddeles til læreren at denne elevs resultat ikke kan anvendes i det videre arbejde med eleven. Vi har med ovenstående analyser vist at sådanne forløb kan identificeres, og at man derfor kan gøre noget ved det ( $\mathrm{fx}$ se bort fra opgaver eller forkaste resultatet).

Men det skal også understreges at dette problem ikke er et særtræk ved det adaptive system, men et generelt problem for alle test. It-baserede test (adaptive eller lineære) kan opdage det mens det sker, hvilket man således kunne udnytte, fx til at gøre læreren opmærksom på problemet undervejs. 


\section{Konklusioner og anbefalinger}

Analyserne i denne rapport har afdækket en række bekymrende træk ved de nationale test. En opsamling på analyserne findes i det indledende resume, kapitel (2.3). Der er samlet set tale om:

a) at itemsværhedsgraderne som nationale tests algoritme bruger, ikke stemmer med de oplevede sværhedsgrader i 2017,

b) at dygtighederne for nogle elevers vedkommende estimeres forkert,

c) at nationale test for mange elevers vedkommende ikke måler så præcist som lovet,

d) at en for stor andel af elevernes testforløb ikke stemmer med forudsætningerne i Rasch-modellen, samt

e) at algoritmen udviser tegn på stiafhængighed (eller stopper for tidligt i processen).

I forhold til den sidste konklusion, er spørgsmålet om man kan gøre noget på forhånd. Det vil blandt andet kræve noget af læreren som jo har ansvaret for at instruere eleverne på den bedste måde så de ikke falder ud undervejs eller til sidst eller tror at de skal skynde sig for at besvare så mange opgaver som muligt.

Vi vil opfordre til at man i adaptive systemer tager højde for at der kan være gået noget galt i starten. Hvis eleverne af den ene eller den anden grund er nervøse, ukoncentrerede eller bliver overraskede over opgaverne i starten af forløbet og bliver slået ud af at de får uløselige opgaver, så ødelægger det testresultaterne. Et forslag kunne være at man lader læreren bestemme hvor systemet skal starte (enten for klassen eller for enkelte elever).

En anden løsning kunne være at blande de meget lette/svære spørgmål som er resultatet af mange indledende forkerte/rigtige, med spørgsmål af middel sværhedsgrad for at sikre at elevens indledende præstation ikke skyldtes held, utilpashed eller andre forstyrrelser.

En tredje løsning kunne være kun at anvende opgaver fra midterfeltet i run in-perioden så det indledende estimat af elevdygtigheden ikke ender så ekstremt som det gør ved tre indledende ens svarresultater.

Alternativt kunne man lade systemet starte med tre opgaver der er så lette at der ikke er nogen elever der får problemer, men som heller ikke bidrager med noget. Denne løsning har klare fordele, men den koster rent tidsmæssigt og forøger SEM'en.

Begrebet stiafhængighed bruges i samfundsvidenskaben til at beskrive det fænomen at når et politisk system er valgt, bliver det vanskeligere at skifte til et andet system. Selvom beregning af dygtigheden i Raschmodeller er noget helt andet, og selvom resultaterne af forkerte svar på slutresultatet, hvis eleven kommer til at svare forkert på lette opgaver, er de samme uanset om det sker i starten eller i midten eller i slutningen af resultatet, så kan situationer, hvor starten af testforløbet af den ene eller anden grund mislykkes, føre til forløb der synes at være præget af stiafhængighed.

Dette skyldes to forhold. For det første at fire fejl i de første opgaver, af årsager der intet har med elevens færdigheder at gøre, under alle omstændigheder vil trække den samlede vurdering af dygtigheden ned. Det vil se slemt ud i starten, men efterhånden som eleven svarer på nye opgaver på en måde der (kun) afhænger af hvor dygtig eleven er, vil det samlede estimat blive realistisk om end en smule for lavt på grund af starten. Præcis hvor mange ekstra opgaver der skal til, er så vidt vi ved ikke undersøgt, men der er ingen grund til at tro at forløb med 10-20 opgaver kan kompensere for en mislykket start med fire eller flere fejlslagne svar på opgaver.

Dette problem er gældende for alle almindelige test. Det er kun fordi der er tale om adaptive test, at problemerne bliver synlige. 
Den anden årsag er at der er tale om en adaptiv test. Den adaptive algoritme vil får det indtryk, at der er tale om en meget svag elev og vil derfor vælge opgaver, der er alt for lette for eleven. De korrekte svar vil naturligvis trække vurderingen af dygtigheden op, men da der er tale om lette opgaver, vil det ikke være lige så stærkt som hvis eleven havde vist at hun kunne svare korrekt på vanskelige opgaver. Til syvende og sidst vil vurderingen også blive realistisk, men der skal mange flere opgaver til end i almindelige test, fordi den adaptive algoritme vil fors $\varnothing$ ge at "vise hensyn" og ikke give eleven opgaver over det alt for lave niveau som algoritmen har placeret eleven på på grund af den mislykkede start på forløbet.

I den forstand har alle pædagogiske test problemer der minder om stiafhængighed, og problemerne er særlig mærkbare, når det drejer sig om adaptive test.

De ret bekymrende resultater der er opregnet først i kapitlet, giver i øvrigt anledning til flere overvejelser.

For det første er de problemer der er identificeret i denne rapport, ikke fuldstændig overraskende. I 2015 opdagede matematiklærer Jørgen Damgaard fra Ørum Skole i Norddjurs at der var meget stor forskel på resultater fra to nationale test taget med få dages mellemrum. Dette førte til at Norddjurs kommune stillede Undervisningsministeriet en række spørgsmål (Harbo 2015) som siden ledte til at Undervisningsministeriet udgav et notat om resultaterne i den pågældende klasse (Styrelsen for Undervisning og Kvalitet 2016). I forbindelse hermed udarbejdede ministeriet også et overordnet notat om "Undersøgelse af de nationale tests reliabilitet" (Styrelsen for It og Læring 2016b). Dette notat indeholder en række iagttagelser som burde have fået alarmklokkerne til at lyde.

I figur 6.1 ses resultaterne af en korrelationsanalyse af sammenhængen mellem resultater for elever der har taget to på hinanden følgende frivillige test i efteråret 2014. 32.566 elever tog den samme test to gange, og der var i gennemsnit 22 dage imellem testene og maksimalt 53 dage. Korrelationskoefficienterne er et udtryk for hvor stor overensstemmelse der er imellem de to resultater. Fuldstændig overensstemmelse (alle er blevet lige meget dygtigere mellem de to test) vil give værdien 1. I rapporten gives følgende retningslinjer for vurderingen af koefficienterne:

Generel guideline til vurdering af reliabilitet: ' $0,0-0,5$ ' $=$ uacceptabel; ' $0,5-0,6$ ' $=$ dårlig; ' $0,6-0,7$ ' $=$ tvivlsom; '0,7-0,8'=acceptabel; '0,8-0,9'=god; '0,9-1,0'=fremragende

Disse tommelfingerregler stammer tilsyneladende fra generelle retningslinjer om korrelationer. Men i dette tilfælde er der tale om test-gentest-korrelationer som er et blandt flere mål for reliabiliteten af test (Feinman 2008). Som omtalt tidligere stilles normalt krav om en realibilitet på mindst 0,9 for individuelle målinger af elever.

Tabel $6 \begin{gathered}\text { Sammenhængen mellem fors } \emptyset \mathrm{g} \mathbf{1} \text { og fors } \varnothing \mathrm{g} \mathbf{2} \text { i elevdygtig- } \\
\text { heden målt på logit skalaen. Pearson korrelationen }\end{gathered}$
\begin{tabular}{|l|c|c|c|c|}
\hline Test & $\begin{array}{c}\text { Antal } \\
\text { elever }\end{array}$ & $\begin{array}{c}\text { Profil- } \\
\text { område 1 }\end{array}$ & $\begin{array}{c}\text { Profil- } \\
\text { område 2 }\end{array}$ & $\begin{array}{c}\text { Profil- } \\
\text { område 3 }\end{array}$ \\
\hline Dansk/læsning 2. klasse & 6.057 & $0,57^{*}$ & $\mathbf{0 , 8 0 ^ { * }}$ & $\mathbf{0 , 7 5 ^ { * }}$ \\
\hline Dansk/læsning 4. klasse & 4.421 & $0,63^{*}$ & $\mathbf{0 , 7 8 ^ { * }}$ & $\mathbf{0 , 7 5 ^ { * }}$ \\
\hline Dansk/læsning 6. klasse & 5.134 & $0,56^{*}$ & $\mathbf{0 , 8 1 ^ { * }}$ & $\mathbf{0 , 7 3 ^ { * }}$ \\
\hline Dansk/læsning 8. klasse & 2.558 & $0,66^{*}$ & $\mathbf{0 , 7 4 ^ { * }}$ & $\mathbf{0 , 7 4 ^ { * }}$ \\
\hline Matematik 3. klasse & 7.590 & $0,60^{*}$ & $0,56^{*}$ & $0,66^{*}$ \\
\hline Matematik 6. klasse & 5.440 & $0,61^{*}$ & $0,56^{*}$ & $0,60^{*}$ \\
\hline Engelsk 7. klasse & 2.424 & $\mathbf{0 , 7 6 ^ { * }}$ & $\mathbf{0 , 7 7 ^ { * }}$ & $\mathbf{0 , 8 0 ^ { * }}$ \\
\hline Fysik/kemi 8. klasse & 1.169 & $0,45^{*}$ & $0,41^{*}$ & $0,39^{*}$ \\
\hline Biologi 8. klasse & 761 & $0,41^{*}$ & $0,49^{*}$ & $0,50^{*}$ \\
\hline Geografi 8. klasse & 1.028 & $0,47^{*}$ & $0,47^{*}$ & $0,45^{*}$ \\
\hline
\end{tabular}

Figur 6.1 Tabel 6 i Styrelsen for It og Læring 2016a: Korrelationer mellem elevernes resultater ved en frivillig og en obligatorisk test. 
Som det fremgår af tabellen lever otte af de i alt 30 profilområder op til karakteristikken "acceptabel", og tre opnår karakteristikken "god". De 19 øvrige profilområder udviser tegn på "tvivlsom", "dårlig" eller sågar "uacceptabel" korrelation mellem de to tests.

I notatets sammenfatning af undersøgelsen (s. 1) omtales dette resultat således:

I alle profilområder er der en statistisk signifikant positiv sammenhæng mellem elevdygtigheden bestemt ved første og ved andet fors $\varnothing \mathrm{g}$ i de frivillige test. Specielt i afkodning og tekstforståelse i dansk læsning samt i engelsk er der en høj korrelation mellem to gentagne test.

Generelt er korrelationen mellem elevens samlede vurdering i fors $\emptyset \mathrm{g} 1$ og fors $\varnothing \mathrm{g} 2$ på 0,79.

I vores фjne er denne sammenfatning ikke på nogen måde et rimeligt udtryk for de problemer som afdækkes med tabellen over korrelationer. Denne tabel tyder på grundlæggende problemer med testen, og det forekommer os uforståeligt at den ikke gav anledning til grundige undersøgelser af om der var fejl i nationale tests algoritme eller i estimeringen af itemsværhedsgrader.

I notatet beregnes også om udviklingen fra test 1 til test 2 fordeler sig som ventet. Notatet forklarer fremgangsmåden således:

For hver elev beregnes en standardiseret forskel, U, på den estimerede elevdygtighed

$$
U=\frac{D_{1}-D_{2}}{\sqrt{\left(S E M_{1}^{2}+S E M_{2}^{2}\right)}}
$$

Her er $D_{1}$ og $D_{2}$ lig den estimerede elevdygtighed til første og andet forsøg, mens $\mathrm{SEM}_{1}$ og $\mathrm{SEM}_{2}$ er de tilhørende estimerede usikkerheder. Justeres endvidere med den gennemsnitlige niveauforskel fra første til andet fors $\varnothing$, da vil U følge en standard normalfordeling. I denne fordeling forventes $95 \%$ af elevernes resultater at ligge mellem $-1,96 \mathrm{og}+1,96$ mens $5 \%$ af elevernes resultater forventes at ligge udenfor $\pm 1,96$ (Styrelsen for It og Læring 2016b, 8).

Resultaterne af denne analyse fremgår af figur 6.2.

Tabel 5 Andelen af elever, hvor forskellen i elevdygtigheden i første og andet fors $\emptyset \mathrm{g}$ ligger uden for $95 \%$ sikkerhedsinterval

\begin{tabular}{|l|c|c|c|c|}
\hline Test & $\begin{array}{c}\text { Antal } \\
\text { elever }\end{array}$ & $\begin{array}{c}\text { Profil- } \\
\text { område 1 }\end{array}$ & $\begin{array}{c}\text { Profil- } \\
\text { område 2 }\end{array}$ & $\begin{array}{c}\text { Profil- } \\
\text { område 3 }\end{array}$ \\
\hline Dansk/læsning 2. klasse & 6.057 & $16 \%$ & $20 \%$ & $24 \%$ \\
\hline Dansk/læsning 4. klasse & 4.421 & $13 \%$ & $11 \%$ & $12 \%$ \\
\hline Dansk/læsning 6. klasse & 5.134 & $11 \%$ & $8 \%$ & $11 \%$ \\
\hline Dansk/læsning 8. klasse & 2.558 & $14 \%$ & $14 \%$ & $8 \%$ \\
\hline Matematik 3. klasse & 7.590 & $12 \%$ & $11 \%$ & $14 \%$ \\
\hline Matematik 6. klasse & 5.440 & $13 \%$ & $9 \%$ & $12 \%$ \\
\hline Engelsk 7. klasse & 2.424 & $5 \%$ & $12 \%$ & $9 \%$ \\
\hline Fysik/kemi 8. klasse & 1.169 & $8 \%$ & $6 \%$ & $9 \%$ \\
\hline Biologi 8. klasse & 761 & $8 \%$ & $5 \%$ & $6 \%$ \\
\hline Geografi 8. klasse & 1.028 & $7 \%$ & $7 \%$ & $8 \%$ \\
\hline
\end{tabular}

Figur 6.2 Tabel 5 i Styrelsen for It og Læring 2016a: Andelen af elever hvor forskellen mellem estimaterne af dygtighed ligger uden for 95 procent-sikkerhedsintervallet.

Som det fremgår af tabellen, opfylder i bedste fald to af de 30 profilområder kravet om at være under 5 procent. De resterende 28 har værdier der er større. I profilområde 3 for læsning i 2. klasse har ikke mindre end 24 procent af eleverne fået en score ved den anden test der adskiller sig signifikant fra den forventede.

Tabellen kommenteres således: 
I alt ligger 12 procent af forskellene mellem elevdygtighederne i fors $\varnothing \mathrm{g} 1$ og fors $\varnothing \mathrm{g} 2$ udenfor det forventede, hvilket er lidt mere end de 5 procent, der forventes i en normalfordeling (tabel 5). Spredningen i elevernes resultater mellem første og andet forsøg er således lidt større end, der forventes, og større end usikkerheden (SEM) på elevdygtighederne kan forklare (Styrelsen for It og Læring 2016b, 8).

Karakteristikken af forskellen mellem de forventede (og acceptable) fem procent og de iagttagede 12 procent som "lidt større end der forventes" finder vi upræcis. Der er tale om en forskel på 140 procent. Og også denne iagttagelse burde have ført til undren og yderligere undersøgelser. Dette resultat omtales ikke i sammenfatningen til notatet.

Notatet formidler flere resultater end disse, fx at de opgaver eleverne får ved den anden test, for 25 procents vedkommende allerede er set ved den første test. For dansk, læsning 8. klasse drejer det sig om 50 procent af opgaverne.

Som sagt er det vores opfattelse af disse resultater hver for sig og samlet burde have ført til en meget grundig undersøgelse af måleegenskaberne ved nationale test i stil med den undersøgelse vi har gennemført i denne rapport.

\subsection{Usikkerheden på resultaterne}

Der har som omtalt i indledningen været stort fokus på de problemer den store usikkerhed på resultaterne fra nationale test indebærer. Denne undersøgelse har vist at der for ganske store andele af elever er tale om endog større usikkerheder end de i forvejen alt for høje målestandardfejl på 0,55 logit. I praksis betyder det at læreren ikke får informationer om sine elever som hun ikke allerede havde en god fornemmelse af. En pædagogisk test bør have en SEM på mindre end 0,3 logit sådan som det var forventningen i de første år af testens levetid.

\subsection{Konsekvenser for forskning, kvalitetssikring og beslutninger om indsatser}

Vi har i denne rapport peget på en række bekymrende træk ved nationale tests måleegenskaber. Disse resultater må føre til at aktørerne på en lang række områder tager hidtidige beslutninger op til fornyet overvejelse.

\subsubsection{Forskning baseret på nationale test - kan vi stole på den?}

Der er foretaget en del forskning der har taget udgangspunkt i resultater fra nationale test. Det handler fx om undersøgelser af sammenhænge mellem elevbaggrund og nationale test, det handler om vurdering af udviklings- og forskningsindsatser osv. Denne undersøgelse må resultere i at resultater fra forskning og evaluering der har taget udgangspunkt i data fra nationale test, tages op til fornyet unders $\varnothing$ gelse.

\subsubsection{Skolereformen - er succeskriteriet troværdigt?}

Nationale test blev ved vedtagelsen af skolereformen i 2013 indskrevet i den politiske aftale som et blandt flere måltal: 
Mål 1. Folkeskolen skal udfordre alle elever, så de bliver så dygtige, de kan

Resultatmål 1.1. for mål 1: Mindst 80 pct. af eleverne skal være gode til at læse og regne i de nationale test ("Aftale Mellem Regeringen (Socialdemokraterne, Radikale Venstre Og Socialistisk Folkeparti), Venstre

Og Dansk Folkeparti Om et Fagligt Løft Af Folkeskolen” 2013).

Nærværende undersøgelse rejser tvivl om hvorvidt der kan fæstes lid til de hidtidige evalueringer af dette måltal.

\subsubsection{Beslutninger om lærere og skoler - kan vi stole på dem?}

Nationale test blev oprindeligt præsenteret som et pædagogisk redskab (Bundsgaard 2018c; Undervisningsminister Bertel Haarder (V) 2006), men blev kort efter vedtagelsen også integreret i lov nr. 572 om ændring af lov om folkeskolen. Heri hed det blandt andet at:

»§ 13 a. Undervisningsministeren offentliggør på baggrund af de afholdte test, jf. § 13, stk. 3, hvert år landsresultaterne.

Stk. 2. Kommunalbestyrelsen og skolelederen får oplyst den enkelte skoles testresultater set i forhold til det samlede landsresultat. Heri skal indgå en vurdering af skolens testresultater set i forhold til elevernes sociale baggrund.«("Lov Om Ændring Af Lov Om Folkeskolen” 2006)

Nærværende undersøgelse af nationale tests måleegenskaber må føre til overvejelser over om den kommunale og lokale kvalitetssikring af skoler og undervisning har hvilet på et forkert grundlag.

\subsubsection{Beslutninger om elever - var de velbegrundede?}

Nationale test skal indgå i lærernes arbejde med eleverne, og forældrene skal informeres om resultatet. Derfor har nationale test opnået en central placering i beslutningsprocesserne om eleverne (Bundsgaard og Puck 2016). Resultaterne er indgået i beslutninger om tildeling af specialindsatser, ved fastsættelse af standpunktskarakterer, ved holdinddeling af elever, ved beslutning om behov for ekstra fokus på faglige områder osv.

Denne undersøgelse har sandsynliggjort at alle disse beslutninger hviler på et usikkert grundlag og derfor bør genevalueres.

\subsection{Pædagogiske test i skolen}

Begrundelsen ved folketingsdebatten i 2005-2006 for indførelsen af nationale test var at testene skulle fungere som et pædagogisk redskab. Der er i vores øjne ikke tvivl om at pædagogiske test kan tjene meget vigtige formål både i forhold til diagnostisering af elever med faglige vanskeligheder, som led i lærerens evaluering af sin undervisning og forberedelse til ny undervisning, som indsigt i faglige kompetencer og udfordringer for grupper af elever mv. Nationale test kan ikke fungere som et sådant redskab i den nuværende version.

Vores opfordring er på denne baggrund at nationale test sæettes på pause indtil såvel årsagerne som konsekvenserne af problemerne er grundigt undersøgt. Vores opfordring er også at man genovervejer hvilke værktøjer lærerne faktisk har brug for for at skabe den forbedrerede evalueringskultur der var begrundelsen for at indføre nationale test.

Vi vil opfordre til at man løsriver brugen af test som pædagogisk redskab fra brugen af test til kvalitetssikring. 
Og vi vil opfordre til at man udvikler en række af kvalitetstest som lærerne kan tage i anvendelse når de ser et behov for det.

Sådanne test skal for det første teste et meget bredere spektrum af de faglige mål end nationale test gør.

For det andet skal de bygge på nyere forskning i autentiske testsituationer (fx Bundsgaard 2018a; Bundsgaard 2016; Care, Scoular, og Griffin 2016; Siddiq, Gochyyev, og Wilson 2017; Geisinger 2016; Greenstein 2012; Griffin og Care 2015).

Og for det tredje skal de have tilstrækkelig høj psykometrisk kvalitet.

På trods af den indlysende fordel ved adaptive test i forhold til at opnå større sikkerhed i resultatet på kortere tid, er vores vurdering på baggrund af denne rapport og vores tidligere arbejde med nationale test, at den helt igennem adaptive tilgang som er valgt med nationale test, resulterer i større problemer end den løser. Vores anbefaling er derfor at man anvender mindre omfattende adaptive tilgange, som fx det såkaldte staged adaptive testing hvor eleverne svarer på en række opgaver hvorefter de tildeles en ny række opgaver som passer til det niveau besvarelsen af den første sekvens af opgaver har estimeret dem til. Derved kan man udvikle mere avancerede opgaver, som kan teste mere varierede aspekter af de faglige områder. 


\section{Litteratur}

Adams, Raymond J., og Mark Wilson. 1996. "Formulating the Rasch Model as a Mixed Coefficients Multinomial Logit Model". I Objective Measurement: Theory into Practice Volume 3, 143-66. Norwood, NJ: Ablex Publishing.

Adams, Raymond J., og Margaret L. Wu. 2007. "The Mixed-Coefficients Multinomial Logit Model: A Generalized Form of the Rasch Model". I Multivariate and Mixture Distribution Rasch Models, redigeret af Matthias von Davier og Claus H. Carstensen, 57-76. New York: Springer Science Business Media.

Adams, Raymond J., Mark Wilson, og Wen-chung Wang. 1997. "The Multidimensional Random Coefficients Multinomial Logit Model". Applied Psychological Measurement 21 (1): 1-23.

"Aftale Mellem Regeringen (Socialdemokraterne, Radikale Venstre Og Socialistisk Folkeparti), Venstre Og Dansk Folkeparti Om et Fagligt Løft Af Folkeskolen". 2013.

Boch, R.D., og M. Aitken. 1981. "Marginal Maximum Likelihood Estimation of Item Parameters: Application of an EM Algorithm". Psykometrika, nr. 46: 443-59.

Bundsgaard, Jeppe. 2016. "Rapport Om Kompetencetest i Hitte På-Projektet". København: DPU, Aarhus Universitet.

—. 2018a. "Det 21. Århundredes Kompetencer". I Skoleudvikling Med It: Forskning $i$ Tre Demonstrationsskolefors $\varnothing g$ I, redigeret af Jeppe Bundsgaard, Marianne Georgsen, Stefan Graf, og Thomas Illum Hansen, 143-65. Aarhus: Aarhus Universitetsforlag.

- 2018b. "Test Og Måling i Fagene". I Udvikling i Didaktik Didaktik $i$ Udvikling, redigeret af Torben Spanget Christensen, Nikolaj Elf, Peter Hobel, og Ane Qvortrup. Aarhus: Klim.

. 2018c. "Pædagogisk brug af test". Sakprosa 10 (2). doi:10.5617/sakprosa.6007.

Bundsgaard, Jeppe, og Morten Rasmus Puck. 2016. Nationale Test - Danske Larere Og Skolelederes Brug, Holdninger Og Viden. DPU, Aarhus Universitet.

Care, Esther, Claire Scoular, og Patrick Griffin. 2016. "Assessment of Collaborative Problem Solving in Education Environments". Applied Measurement in Education 29 (4): 250-64. doi:10.1080/08957347.2016.1209204.

Feinman, Joshua. 2008. "High Stakes, but Low Validity? A Case Study of Standardized Tests and Admissions 
into New York City Specialized High Schools." Boulder; Tempe: Education and the Public Interest Center \& Education Policy Research Unit.

Geisinger, Kurt F. 2016. "21st Century Skills: What Are They and How Do We Assess Them?" Applied Measurement in Education 29 (4): 245-49. doi:10.1080/08957347.2016.1209207.

Greenstein, Laura M. 2012. Assessing 21st Century Skills: A Guide to Evaluating Mastery and Authentic Learning. Corwin Press.

Griffin, Patrick, og Esther Care, red. 2015. Assessment and Teaching of 21st Century Skills. Dordrecht: Springer Netherlands. doi:10.1007/978-94-017-9395-7.

Hale, Charles Dennis, og Douglas Astolfi. 2014. Measuring Learning and Performance: A Primer. 3rd edition. St. Leo, Florida: Saint Leo University.

Harbo, Ulf. 2015. "Norddjurs kommune udfordrer de Nationale test - Folkeskolen.dk". https://www.folkeskolen.dk/573670/norddjurs-kommune-udfordrer-de-nationale-test.

Hoover, Wesley A., og Philip B. Gough. 1990. "The Simple View of Reading". Reading and writing 2 (2): $127-60$.

Kousholt, Kristine. 2015. "Børns Gætterier Ved Nationale Test”. Cepra-striben, Nationale Tests,, nr. 18: $46-57$.

Kreiner, Svend. 2007. "Den Adaptive Procedure".

Kreiner, Svend, og Karl Bang Christensen. 2013. "Person Parameter Estimation and Measurement in Rasch Models". I Rasch Models in Health, redigeret af Karl Bang Christensen, Svend Kreiner, og M Mesbah, 63-78. London: ISTE \& John Wiley \& Sons.

"Lov Om Ændring Af Lov Om Folkeskolen". 2006.

Norling, Marina. 2016. "De nationale test 2016 - hvor galt står det til? (1) - Folkeskolen.dk". Folkeskolen.dk. https://www.folkeskolen.dk/586828/de-nationale-test-2016 - hvor-galt-staar-det-til-1.

Rasch, G. 1960. Probabilistic Models for Some Intelligence and Attainment Tests. Studies in Mathematical Psychology, Vol. 1. Copenhagen: Danmarks Pædagogiske Institut.

Ravn, Karen. 2014. "Ups de nationale test måler ikke så præcist som lovet - Folkeskolen.dk". Folkeskolen.dk. https://www.folkeskolen.dk/539694/ups-de-nationale-test-maaler-ikke-saa-praecist-som-lovet.

—. 2015a. "Duer ikke: En femtedel af opgaverne i de nationale test kasseret - Folkeskolen.dk". folkeskolen.dk. https://www.folkeskolen.dk/572751/duer-ikke-en-femtedel-af-opgaverne-i-de-nationale-testkasseret.

—. 2015b. "Eksperter dumper de nationale test - Folkeskolen.dk". Folkeskolen.dk. https://www.folkeskolen.dk/572813/eksperter-dumper-de-nationale-test.

_. 2015c. "Skoleleder: Testresultater svinger, som vinden blæser - Folkeskolen.dk". Folkeskolen.dk. https://www.folkeskolen.dk/572808/skoleleder-testresultater-svinger-som-vinden-blaeser.

Riise, Andreas Brøns. 2014. "Nationale test: Klasse havde kæmpe udsving på tre dage - Folkeskolen.dk". https://www.folkeskolen.dk/540229/nationale-test-klasse-havde-kaempe-udsving-paa-tre-dage.

Robitzsch, Alexander, Thomas Kiefer, og Margaret Wu. 2019. TAM: Test Analysis Modules. https://CRAN. R-project.org/package $=$ TAM.

Rosenbaum, Paul R. 1989. "Criterion-Related Construct Validity". Psychometrika 54 (4): 625-33. doi:10.1007/BF02296400.

Siddiq, Fazilat, Perman Gochyyev, og Mark Wilson. 2017. "Learning in Digital Networks Literacy: 
A Novel Assessment of Students' 21st Century Skills". Computers \& Education 109 (juni): 11-37. doi:10.1016/j.compedu.2017.01.014.

Smarter Balanced Assessment Consortium. 2018. "Smarter Balanced Assessment Consortium: 2016-17 Technical Report".

Styrelsen for It og Læring. 2015. "Den adaptive algoritme i De Nationale Test". København: Undervisningsministeriet, Styrelsen for It og Læring.

- 2016a. Test- Og Prøvesystemet - De Nationale Test. Brugervejledning for Skoler. København: Ministeriet for Børn, Unge og Undervisning.

—. 2016b. "Undersøgelse af de nationale tests reliabilitet". København: Undervisningsministeriet.

—_. 2016c. "Nationale Tests Måleegenskaber". København: Undervisningsministeriet.

—. 2017. "Vejledning Til Nye Resultatvisninger i de Nationale Test Til Lærere i Alle Fag". København: Styrelsen for It og Læring.

Styrelsen for Undervisning og Kvalitet. 2016. "Undersøgelse Af Udsving i Testresultater På Ørum Skole i Norddjurs Kommune". Styrelsen for Undervisning og Kvalitet.

Taylor, Wilson L. 1953. "Cloze Procedure: A New Tool for Measuring Readability". Journalism Es Mass Communication Quarterly 30 (4): 415-33.

Undervisningsminister Bertel Haarder (V). 2006. "L 101 Forslag til lov om ændring af lov om folkeskolen. (Styrket evaluering og anvendelse af nationale test som pædagogisk redskab samt obligatoriske prøver m.v.)."

Wandall, Jakob. 2010. "Test, prøver og evaluering i grundskolen”. Powerpoints. København: IND/KU.

Wandall, Jakob, Christine Nørrelund, og Mette Dalgaard Nielsen. 2018. "Elevernes Syn På de Nationale Test". Nordic Metrics.

Wells, Craig S, og James A Wollack. 2003. "An Instructor's Guide to Understanding Test Reliability". Testing \& Evaluation Services. University of Wisconsin.

Wilson, Mark. 2003. "On Choosing a Model for Measuring". Methods of Psychological Research-Online 8 (3): $1-22$.

2005. Constructing Measures : An Item Response Modeling Approach. Mahwah, N.J.: Lawrence Erlbaum Associates.

Wright, Benjamin D., og Mark H. Stone. 1979. Best Test Design. Chicago: MESA Press.

Wu, Margaret, Raymond J. Adams, Mark Wilson, og S. Haldane. 2007. ConQuest: Generalised Item Response Modelling Software (Version 2.0). Camberwell, Australia: ACER Press.

Zwinderman, A. H. 1995. "Pairwise Parameter Estimation in Rasch Models". Applied Psychological Measurement, nr. 19: 369-75. 
I disse tabeller kan man se

1) hvornår opgaven er besvaret,

2) hvor mange delspørgsmål eleven har haft korrekt,

3) hvor mange delspørgsmål der var i opgaven, samt

4) hvad algoritmen estimerede elevens dygtighed (theta) til efter besvarelsen af opgaven. Bemærk at dette ikke gælder de to første spørgsmål, idet de tre første spørgsmål fungerer som "run in", dvs. at systemet starter med en opgave på et forvalgt sværhedsgradsniveau og derfra stiller et væsentligt sværere spørgsmål (0,25 eller 0,5 logit sværere) hvis eleven svarer rigtigt - og lettere hvis eleven svarer forkert. Efter det tredje spørgsmål estimeres elevens dygtighed for første gang.

5) Desuden fremgår det hvilket nummer spørgsmål dette er for eleven i alt,

6) hvilket nummer spørgsmål det er inden for profilområdet,

7) tiden det tog for eleven i minutter at besvare opgaven (beregnet ud fra starttidspunkt på denne opgave og den følgende).

8) I den ottende søjle angives 2017-analysens estimat af elevens dygtighed (theta-2017). Estimatet er foretaget allerede efter besvarelsen af den første opgave.

9) For 2017-analysen er også angivet usikkerheden på estimatet (SEM-2017).

10) Beta-DNT er nationale tests estimat af opgavens sværhedsgrad, og

11) Beta-2017 er opgavens sværhedsgrad beregnet med udgangspunkt i eleverne fra 2017.

Tabel A.1: Testforløbdata for elev 441985, profilområde 2

\begin{tabular}{|c|c|c|c|c|c|c|c|c|c|c|}
\hline Opgavenummer & Rigtige & Delsp. & Theta & Spnr. & Profilspnr. & Tid & theta-2017 & SEM-2017 & beta-DNT & beta- 2017 \\
\hline 0108020115072 & 1 & 1 & 2,5 & 2 & 1 & 0,51 & 2,7 & 2,20 & 1,9 & 1,377 \\
\hline 010802000301234810-1 & 0 & 1 & 2,0 & 5 & 2 & 1,50 & 1,4 & 1,40 & 2,6 & 1,433 \\
\hline 010802000301234966-1 & 1 & 1 & 2,9 & 8 & 3 & 1,30 & 1,9 & 1,20 & 2,0 & 1,346 \\
\hline 010802000301234959-1 & 0 & 1 & 2,3 & 11 & 4 & 1,60 & 1,6 & 1,00 & 2,8 & 1,985 \\
\hline 010802000301234953-1 & 1 & 1 & 2,7 & 14 & 5 & 0,50 & 1,9 & 0,91 & 2,2 & 1,411 \\
\hline 010802000301234951-1 & 0 & 1 & 2,4 & 17 & 6 & 0,68 & 1,6 & 0,83 & 2,7 & 2,058 \\
\hline 0108020111026 & 1 & 1 & 2,6 & 20 & 7 & 0,43 & 1,8 & 0,77 & 2,3 & 0,837 \\
\hline 0108020110139-1 & 0 & 1 & 2,4 & 23 & 8 & 0,91 & 1,5 & 0,72 & 2,7 & 1,274 \\
\hline 0108020111022 & 1 & 1 & 2,6 & 26 & 9 & 0,98 & 1,7 & 0,68 & 2,5 & 1,532 \\
\hline 010802000301234848-1 & 0 & 1 & 2,4 & 29 & 10 & 2,60 & 1,5 & 0,64 & 2,6 & 2,066 \\
\hline 0108020111019 & 1 & 1 & 2,6 & 31 & 11 & 0,82 & 1,7 & 0,61 & 2,6 & 1,370 \\
\hline 010802000301238021-1 & 1 & 1 & 2,8 & 33 & 12 & 0,66 & 1,8 & 0,59 & 3,0 & 1,323 \\
\hline 0108020111006 & 0 & 1 & 2,7 & 35 & 13 & 1,60 & 1,7 & 0,56 & 2,9 & 1,381 \\
\hline 0108020110268 & 0 & 1 & 2,6 & 37 & 14 & 0,73 & 1,6 & 0,54 & 3,3 & 2,251 \\
\hline 0108020110166-1 & 1 & 1 & 2,8 & 39 & 15 & 2,10 & 1,7 & 0,53 & 3,5 & 2,089 \\
\hline 010802000301239338-1 & 1 & 1 & 3,0 & 42 & 16 & 0,28 & 1,9 & 0,52 & 3,7 & 2,922 \\
\hline 010802000301239337-1 & 0 & 1 & 2,9 & 45 & 17 & 0,57 & 1,9 & 0,51 & 3,7 & 3,363 \\
\hline
\end{tabular}

Tabel A.2: Testforløbdata for elev 421613, profilområde 3

\begin{tabular}{|c|c|c|c|c|c|c|c|c|c|c|}
\hline Opgavenummer & Rigtige & Delsp. & Theta & Spnr. & Profilspnr. & Tid & theta-2017 & SEM-2017 & beta-DNT & beta-2017 \\
\hline 01080306061340005-2 & 0 & 1 & 0,25 & 3 & 1 & 0,56 & $-1,70$ & 2,20 & 0,480 & $-0,493$ \\
\hline 0108030311018 & 0 & 1 & 0,00 & 6 & 2 & 1,90 & $-1,80$ & 1,90 & 0,180 & 0,206 \\
\hline
\end{tabular}


Tabel A.2: Testforløbdata for elev 421613, profilområde 3 (continued)

\begin{tabular}{|c|c|c|c|c|c|c|c|c|c|c|}
\hline Opgavenummer & Rigtige & Delsp. & Theta & Spnr. & Profilspnr. & Tid & theta-2017 & SEM-2017 & beta-DNT & beta- 2017 \\
\hline 01080306061330044-3 & 0 & 1 & $-2,30$ & 9 & 3 & 0,84 & $-2,00$ & 1,80 & $-0,023$ & 0,246 \\
\hline 010803060613252-4 & 0 & 1 & $-3,90$ & 12 & 4 & 1,10 & $-2,30$ & 1,70 & $-2,400$ & $-0,294$ \\
\hline 0108030320029 & 0 & 1 & $-5,90$ & 15 & 5 & 0,86 & $-3,60$ & 1,80 & $-4,400$ & $-2,351$ \\
\hline 010803060613601-3 & 0 & 1 & $-6,20$ & 18 & 6 & 1,90 & $-4,10$ & 1,70 & $-3,400$ & $-2,229$ \\
\hline 01080306061330109 & 0 & 1 & $-6,40$ & 21 & 7 & 0,48 & $-4,20$ & 1,70 & $-3,000$ & $-1,567$ \\
\hline 0108030320022-3 & 1 & 1 & $-4,70$ & 24 & 8 & 1,30 & $-3,00$ & 1,00 & $-2,700$ & $-1,406$ \\
\hline 0108030320040 & 1 & 1 & $-3,90$ & 27 & 9 & 0,90 & $-2,30$ & 0,84 & $-2,500$ & $-0,915$ \\
\hline $01080306912-1 \_2$ & 1 & 1 & $-3,30$ & 30 & 10 & 2,00 & $-1,90$ & 0,74 & $-2,300$ & $-0,731$ \\
\hline 0108030612006-1 & 1 & 1 & $-2,90$ & 33 & 11 & 2,10 & $-1,60$ & 0,67 & $-2,200$ & $-1,371$ \\
\hline 0108030320033 & 1 & 1 & $-2,60$ & 36 & 12 & 0,84 & $-1,40$ & 0,63 & $-2,100$ & $-1,506$ \\
\hline 01080306061330104 & 1 & 1 & $-2,30$ & 39 & 13 & 1,70 & $-1,20$ & 0,60 & $-2,100$ & $-1,228$ \\
\hline 0108030612019-1 & 0 & 1 & $-2,50$ & 42 & 14 & 2,10 & $-1,30$ & 0,58 & $-1,900$ & $-0,298$ \\
\hline 01080306061330034-2 & 1 & 1 & $-2,30$ & 45 & 15 & 0,85 & $-1,20$ & 0,55 & $-2,000$ & $-0,972$ \\
\hline 0108030310373 & 4 & 4 & $-1,80$ & 48 & 16 & 0,78 & $-0,79$ & 0,44 & $-2,100$ & $-1,077$ \\
\hline 0108030320069-2 & 1 & 1 & $-1,70$ & 51 & 17 & 1,90 & $-0,71$ & 0,44 & $-1,700$ & $-0,927$ \\
\hline 01080303060940011-1 & 1 & 1 & $-1,60$ & 54 & 18 & 0,83 & $-0,63$ & 0,44 & $-1,600$ & $-1,028$ \\
\hline
\end{tabular}

Tabel A.3: Testforløbdata for elev 428314, profilområde 3

\begin{tabular}{|c|c|c|c|c|c|c|c|c|c|c|}
\hline Opgavenummer & Rigtige & Delsp. & Theta & Spnr. & Profilspnr. & Tid & theta-2017 & SEM-2017 & beta-DNT & beta-2017 \\
\hline 010803000301238841-1 & 0 & 1 & 0,25 & 3 & 1 & 2,60 & $-0,500$ & 2,10 & 0,580 & 0,903 \\
\hline $0108030320023-2$ & 0 & 1 & 0,00 & 6 & 2 & 1,00 & $-0,890$ & 1,90 & 0,290 & 0,594 \\
\hline 01080306061330044-3 & 0 & 1 & $-2,30$ & 9 & 3 & 0,74 & $-1,400$ & 1,80 & $-0,023$ & 0,246 \\
\hline $01080306912-1 \_2$ & 1 & 1 & $-1,70$ & 12 & 4 & 1,30 & $-0,730$ & 1,10 & $-2,300$ & $-0,731$ \\
\hline 0108030310024-3 & 1 & 1 & $-1,10$ & 15 & 5 & 0,77 & $-0,530$ & 1,00 & $-1,700$ & $-1,541$ \\
\hline 01080306061330114 & 1 & 1 & $-0,70$ & 18 & 6 & 1,20 & $-0,250$ & 0,89 & $-1,100$ & $-0,898$ \\
\hline 0108030310611-2 & 5 & 5 & 0,29 & 21 & 7 & 1,90 & 0,150 & 0,70 & $-0,340$ & $-0,687$ \\
\hline 010803000301239063-1 & 2 & 5 & 0,12 & 24 & 8 & 4,10 & 0,069 & 0,56 & 0,210 & 0,300 \\
\hline 010803000301241409-1 & 4 & 5 & 0,47 & 39 & 9 & 3,20 & 0,270 & 0,51 & 0,260 & $-0,351$ \\
\hline 0108030310606-1 & 1 & 1 & 0,57 & 42 & 10 & 1,10 & 0,340 & 0,50 & 0,510 & $-0,559$ \\
\hline 010803000301237450-3 & 1 & 1 & 0,68 & 45 & 11 & 1,90 & 0,490 & 0,50 & 0,600 & 0,645 \\
\hline 010803000301235608-1 & 1 & 1 & 0,79 & 48 & 12 & 3,90 & 0,620 & 0,50 & 0,770 & 0,594 \\
\hline 010803000301238350-1 & 1 & 1 & 0,90 & 51 & 13 & 1,40 & 0,790 & 0,50 & 0,850 & 1,317 \\
\hline
\end{tabular}

Tabel A.4: Testforløbdata for elev 387213, profilområde 3

\begin{tabular}{|c|c|c|c|c|c|c|c|c|c|c|}
\hline Opgavenummer & Rigtige & Delsp. & Theta & Spnr. & Profilspnr. & Tid & theta-2017 & SEM-2017 & beta-DNT & beta- 2017 \\
\hline 010803000301238841-1 & 1 & 1 & 0,75 & 3 & 1 & 2,6 & 2,3 & 2,10 & 0,58 & 0,903 \\
\hline $0108030320062-1$ & 1 & 1 & 1,00 & 6 & 2 & 1,4 & 2,3 & 1,90 & 0,79 & 0,335 \\
\hline 0108030320053-1 & 1 & 1 & 3,30 & 9 & 3 & 1,0 & 2,7 & 1,80 & 0,90 & 0,895 \\
\hline 010803000301235582-2 & 1 & 1 & 5,00 & 12 & 4 & 3,5 & 3,9 & 1,90 & 3,40 & 2,680 \\
\hline 010803000301235587-2 & 0 & 1 & 4,30 & 15 & 5 & 5,0 & 3,5 & 1,30 & 4,80 & 4,100 \\
\hline 010803000301235606-2 & 0 & 1 & 3,70 & 18 & 6 & 4,6 & 2,9 & 1,00 & 4,40 & 3,256 \\
\hline 010803000301235578-2 & 0 & 1 & 3,20 & 21 & 7 & 2,6 & 2,7 & 0,93 & 3,70 & 3,674 \\
\hline 010803000301236038-1 & 0 & 1 & 2,90 & 24 & 8 & 4,4 & 2,5 & 0,86 & 3,60 & 3,329 \\
\hline 010803000301235602-2 & 0 & 1 & 2,60 & 27 & 9 & 3,2 & 2,3 & 0,80 & 3,50 & 3,180 \\
\hline 010803000301235608-2 & 0 & 1 & 2,30 & 30 & 10 & 3,4 & 2,0 & 0,76 & 2,70 & 2,323 \\
\hline
\end{tabular}

Tabel A.5: Testforløbdata for elev 341070, profilområde 2

\begin{tabular}{|c|c|c|c|c|c|c|c|c|c|c|}
\hline Opgavenummer & Rigtige & Delsp. & Theta & Spnr. & Profilspnr. & Tid & theta-2017 & SEM-2017 & beta-DNT & beta- 2017 \\
\hline 0108020111016 & 1 & 1 & 2,5 & 2 & 1 & 0,32 & 1,9 & 2,10 & 2,0 & 0,452 \\
\hline 0108020111022 & 1 & 1 & 3,0 & 5 & 2 & 0,65 & 2,8 & 2,00 & 2,5 & 1,532 \\
\hline 010802000301238021-1 & 1 & 1 & 5,1 & 8 & 3 & 0,68 & 3,2 & 1,80 & 3,0 & 1,323 \\
\hline 010802000301239468-1 & 0 & 1 & 4,5 & 11 & 4 & 1,00 & 3,0 & 1,40 & 5,0 & 4,022 \\
\hline 0108020110231 & 0 & 1 & 3,9 & 14 & 5 & 1,10 & 2,4 & 1,10 & 4,5 & 2,768 \\
\hline
\end{tabular}


Tabel A.5: Testforløbdata for elev 341070, profilområde 2 (continued)

\begin{tabular}{|c|c|c|c|c|c|c|c|c|c|c|}
\hline Opgavenummer & Rigtige & Delsp. & Theta & Spnr. & Profilspnr. & Tid & theta-2017 & SEM-2017 & beta-DNT & beta- 2017 \\
\hline 010802000301234818-1 & 0 & 1 & 3,5 & 17 & 6 & 0,20 & 2,2 & 0,95 & 4,1 & 3,185 \\
\hline 0108020110166-1 & 0 & 1 & 3,2 & 20 & 7 & 0,86 & 1,9 & 0,86 & 3,5 & 2,089 \\
\hline 0108020110268 & 0 & 1 & 2,9 & 23 & 8 & 0,28 & 1,6 & 0,81 & 3,3 & 2,251 \\
\hline 0108020111006 & 1 & 1 & 3,1 & 26 & 9 & 0,69 & 1,8 & 0,74 & 2,9 & 1,381 \\
\hline 010802000301239338-1 & 1 & 1 & 3,4 & 29 & 10 & 1,30 & 2,2 & 0,70 & 3,7 & 2,922 \\
\hline 010802000301239337-1 & 0 & 1 & 3,3 & 32 & 11 & 1,10 & 2,1 & 0,67 & 3,7 & 3,363 \\
\hline 010802000301234958-1 & 0 & 1 & 3,1 & 35 & 12 & 1,30 & 2,1 & 0,66 & 4,0 & 3,872 \\
\hline 010802000301234959-1 & 0 & 1 & 2,9 & 38 & 13 & 0,71 & 1,9 & 0,63 & 2,8 & 1,985 \\
\hline 0108020110139-1 & 1 & 1 & 3,1 & 41 & 14 & 0,26 & 2,0 & 0,60 & 2,7 & 1,274 \\
\hline 010802000301234951-1 & 1 & 1 & 3,2 & 43 & 15 & 0,43 & 2,1 & 0,57 & 2,7 & 2,058 \\
\hline 010802000301234848-1 & 1 & 1 & 3,3 & 45 & 16 & 0,89 & 2,3 & 0,55 & 2,6 & 2,066 \\
\hline 0108020111019 & 1 & 1 & 3,4 & 49 & 17 & 0,17 & 2,4 & 0,54 & 2,6 & 1,370 \\
\hline
\end{tabular}

Tabel A.6: Testforløbdata for elev 129172, profilområde 2

\begin{tabular}{|c|c|c|c|c|c|c|c|c|c|c|}
\hline Opgavenummer & Rigtige & Delsp. & Theta & Spnr. & Profilspnr. & Tid & theta-2017 & SEM-2017 & beta-DNT & beta- 2017 \\
\hline 0108020111018 & 0 & 1 & 1,500 & 2 & 1 & 0,553 & $-0,247$ & 2,194 & 2,069 & 1,017 \\
\hline 010802000301234952-1 & 0 & 1 & 1,000 & 5 & 2 & 0,206 & $-0,539$ & 1,897 & 1,497 & 1,073 \\
\hline 0108020111011 & 0 & 1 & $-1,121$ & 8 & 3 & 0,204 & $-1,430$ & 1,819 & 0,945 & $-0,134$ \\
\hline 010802000301234955-1 & 0 & 1 & $-2,711$ & 11 & 4 & 0,122 & $-2,350$ & 1,802 & $-1,138$ & $-0,994$ \\
\hline 0108020115060 & 0 & 1 & $-4,371$ & 14 & 5 & 0,099 & $-2,700$ & 1,704 & $-2,804$ & $-0,719$ \\
\hline 010802000301237986-1 & 1 & 1 & $-3,841$ & 17 & 6 & 0,117 & $-2,075$ & 1,128 & $-4,503$ & $-2,076$ \\
\hline 0108020110177-1 & 1 & 1 & $-3,218$ & 20 & 7 & 0,148 & $-1,561$ & 0,917 & $-3,964$ & $-1,545$ \\
\hline 010802000301237983-1 & 1 & 1 & $-2,707$ & 23 & 8 & 0,089 & $-1,424$ & 0,844 & $-3,190$ & $-2,446$ \\
\hline 0108020110172-1 & 1 & 1 & $-2,271$ & 26 & 9 & 0,247 & $-1,143$ & 0,770 & $-2,635$ & $-1,386$ \\
\hline 0108020110228 & 1 & 1 & $-1,894$ & 29 & 10 & 0,113 & $-0,763$ & 0,726 & $-2,216$ & $-0,223$ \\
\hline 0108020110111-1 & 1 & 1 & $-1,555$ & 32 & 11 & 0,088 & $-0,605$ & 0,689 & $-1,828$ & $-1,152$ \\
\hline 0108020110052-1 & 1 & 1 & $-1,254$ & 35 & 12 & 0,106 & $-0,427$ & 0,658 & $-1,545$ & $-0,795$ \\
\hline 0108020110007-1 & 1 & 1 & $-0,967$ & 37 & 13 & 0,154 & $-0,283$ & 0,634 & $-1,183$ & $-0,766$ \\
\hline 0108020111012 & 1 & 1 & $-0,702$ & 39 & 14 & 0,164 & $-0,100$ & 0,614 & $-0,911$ & $-0,336$ \\
\hline 0108020110053-1 & 1 & 1 & $-0,449$ & 41 & 15 & 0,115 & 0,007 & 0,598 & $-0,606$ & $-0,901$ \\
\hline 010802000301234962-1 & 1 & 1 & $-0,219$ & 43 & 16 & 0,163 & 0,105 & 0,584 & $-0,422$ & $-0,757$ \\
\hline 0108020110261 & 1 & 1 & 0,004 & 44 & 17 & 0,179 & 0,251 & 0,573 & $-0,142$ & 0,046 \\
\hline 0108020110245 & 1 & 1 & 0,212 & 45 & 18 & 0,132 & 0,330 & 0,562 & 0,050 & $-0,808$ \\
\hline 0108020110038-1 & 0 & 1 & 0,032 & 46 & 19 & 0,095 & 0,169 & 0,529 & 0,269 & 0,067 \\
\hline 0108020110219-1 & 1 & 1 & 0,209 & 47 & 20 & 0,151 & 0,290 & 0,520 & 0,126 & 0,137 \\
\hline 0108020110155-1 & 1 & 1 & 0,376 & 48 & 21 & 0,152 & 0,386 & 0,512 & 0,266 & $-0,175$ \\
\hline 0108020110232 & 0 & 1 & 0,230 & 49 & 22 & 0,108 & 0,219 & 0,486 & 0,434 & $-0,518$ \\
\hline 0108020115013 & 1 & 1 & 0,373 & 52 & 23 & 0,334 & 0,320 & 0,479 & 0,285 & 0,005 \\
\hline 0108020110082-1 & 0 & 1 & 0,243 & 55 & 24 & 0,153 & 0,208 & 0,459 & 0,384 & 0,207 \\
\hline 0108020110059-1 & 1 & 1 & 0,370 & 58 & 25 & 0,180 & 0,319 & 0,454 & 0,307 & 0,465 \\
\hline 0108020110003-1 & 1 & 1 & 0,493 & 61 & 26 & 0,104 & 0,373 & 0,449 & 0,459 & $-0,630$ \\
\hline 010802000301234881-1 & 1 & 1 & 0,609 & 64 & 27 & 0,114 & 0,463 & 0,444 & 0,539 & 0,274 \\
\hline 0108020111034 & 1 & 1 & 0,722 & 67 & 28 & 0,181 & 0,536 & 0,439 & 0,652 & 0,058 \\
\hline $0108020110217-1$ & 0 & 1 & 0,620 & 70 & 29 & 0,195 & 0,435 & 0,422 & 0,787 & 0,204 \\
\hline 010802000301239438-1 & 1 & 1 & 0,724 & 73 & 30 & 0,192 & 0,523 & 0,419 & 0,704 & 0,524 \\
\hline 010802000301234811-1 & 0 & 1 & 0,633 & 76 & 31 & 0,281 & 0,443 & 0,405 & 0,805 & 0,500 \\
\hline 0108020110024-1 & 0 & 1 & 0,548 & 79 & 32 & 0,133 & 0,371 & 0,393 & 0,732 & 0,513 \\
\hline 0108020110105-1 & 1 & 1 & 0,636 & 82 & 33 & 0,159 & 0,402 & 0,390 & 0,592 & $-0,887$ \\
\hline 0108020110162-1 & 0 & 1 & 0,560 & 85 & 34 & 0,434 & 0,357 & 0,382 & 0,789 & 1,167 \\
\hline 0108020110234 & 0 & 1 & 0,483 & 88 & 35 & 0,088 & 0,266 & 0,372 & 0,596 & $-0,301$ \\
\hline 0108020110205-1 & 1 & 1 & 0,575 & 91 & 36 & 0,218 & 0,325 & 0,368 & 0,936 & 0,015 \\
\hline 0108020110079-1 & 1 & 1 & 0,661 & 94 & 37 & 0,134 & 0,386 & 0,364 & 0,916 & 0,221 \\
\hline 0108020110018-1 & 1 & 1 & 0,739 & 97 & 38 & 0,116 & 0,438 & 0,361 & 0,847 & 0,002 \\
\hline 0108020111031 & 0 & 1 & 0,675 & 100 & 39 & 0,148 & 0,365 & 0,352 & 0,878 & 0,059 \\
\hline 0108020110156-1 & 0 & 1 & 0,615 & 103 & 40 & 0,279 & 0,293 & 0,345 & 0,864 & $-0,089$ \\
\hline 0108020115028 & 0 & 1 & 0,566 & 106 & 41 & 0,188 & 0,235 & 0,338 & 1,113 & 0,193 \\
\hline 0108020110085-1 & 1 & 1 & 0,642 & 109 & 42 & 0,141 & 0,284 & 0,335 & 1,009 & 0,059 \\
\hline 010802000301234855-1 & 0 & 1 & 0,592 & 112 & 43 & 0,130 & 0,232 & 0,329 & 0,990 & 0,278 \\
\hline
\end{tabular}


Tabel A.6: Testforløbdata for elev 129172, profilområde 2 (continued)

\begin{tabular}{|c|c|c|c|c|c|c|c|c|c|c|}
\hline Opgavenummer & Rigtige & Delsp. & Theta & Spnr. & Profilspnr. & Tid & theta-2017 & SEM-2017 & beta-DNT & beta- 2017 \\
\hline 0108020110206-1 & 1 & 1 & 0,663 & 115 & 44 & 0,215 & 0,288 & 0,326 & 1,032 & 0,357 \\
\hline 0108020110144-1 & 0 & 1 & 0,614 & 118 & 45 & 0,177 & 0,240 & 0,321 & 0,916 & 0,361 \\
\hline 0108020110137-1 & 1 & 1 & 0,681 & 121 & 46 & 0,139 & 0,303 & 0,318 & 1,035 & 0,815 \\
\hline 0108020110131-1 & 1 & 1 & 0,740 & 124 & 47 & 0,137 & 0,350 & 0,316 & 0,877 & 0,244 \\
\hline 0108020110006-1 & 1 & 1 & 0,798 & 127 & 48 & 0,125 & 0,381 & 0,313 & 0,904 & $-0,490$ \\
\hline 0108020110088-1 & 1 & 1 & 0,853 & 130 & 49 & 0,335 & 0,429 & 0,311 & 0,892 & 0,496 \\
\hline 0108020110036-1 & 0 & 1 & 0,803 & 133 & 50 & 0,210 & 0,380 & 0,306 & 0,904 & 0,322 \\
\hline 0108020111023 & 1 & 1 & 0,855 & 136 & 51 & 0,117 & 0,421 & 0,303 & 0,899 & 0,216 \\
\hline 0108020111033 & 1 & 1 & 0,906 & 139 & 52 & 0,144 & 0,459 & 0,301 & 0,945 & 0,115 \\
\hline 0108020110074-1 & 0 & 1 & 0,860 & 142 & 53 & 0,105 & 0,416 & 0,296 & 0,979 & 0,396 \\
\hline 0108020115027 & 1 & 1 & 0,911 & 145 & 54 & 0,097 & 0,455 & 0,294 & 1,057 & 0,272 \\
\hline 0108020110164-1 & 1 & 1 & 0,960 & 148 & 55 & 0,126 & 0,474 & 0,293 & 1,045 & $-0,812$ \\
\hline 0108020110267 & 0 & 1 & 0,919 & 151 & 56 & 0,164 & 0,433 & 0,289 & 1,130 & 0,467 \\
\hline 010802000301234956-1 & 0 & 1 & 0,884 & 154 & 57 & 0,193 & 0,393 & 0,285 & 1,305 & 0,415 \\
\hline 010802000301234946-1 & 1 & 1 & 0,936 & 157 & 58 & 0,123 & 0,430 & 0,283 & 1,353 & 0,247 \\
\hline 0108020111004 & 1 & 1 & 0,984 & 160 & 59 & 0,322 & 0,459 & 0,281 & 1,205 & $-0,059$ \\
\hline 0108020110263 & 0 & 1 & 0,946 & 163 & 60 & 0,139 & 0,425 & 0,277 & 1,155 & 0,619 \\
\hline 0108020110201-1 & 1 & 1 & 0,993 & 166 & 61 & 0,150 & 0,460 & 0,275 & 1,273 & 0,287 \\
\hline
\end{tabular}

Tabel A.7: Testforløbdata for elev 104649, profilområde 3

\begin{tabular}{|c|c|c|c|c|c|c|c|c|c|c|}
\hline Opgavenummer & Rigtige & Delsp. & Theta & Spnr. & Profilspnr. & Tid & theta-2017 & SEM-2017 & beta-DNT & beta- 2017 \\
\hline 010803000301238303-1 & 0 & 1 & 0,25 & 3 & 1 & 0,082 & $-1,217$ & 2,360 & 0,585 & $-0,201$ \\
\hline 010803000301238855-1 & 0 & 1 & 0,00 & 6 & 2 & 0,093 & $-1,441$ & 1,967 & 0,272 & 0,822 \\
\hline 01080306061340014 & 0 & 1 & $-2,32$ & 9 & 3 & 0,497 & $-1,910$ & 1,783 & $-0,097$ & $-0,255$ \\
\hline 010803060613252-4 & 0 & 1 & $-3,94$ & 12 & 4 & 0,223 & $-2,245$ & 1,691 & $-2,377$ & $-0,294$ \\
\hline 0108030320029 & 0 & 1 & $-5,85$ & 15 & 5 & 0,423 & $-3,571$ & 1,865 & $-4,356$ & $-2,351$ \\
\hline 010803060613601-3 & 1 & 1 & $-4,24$ & 18 & 6 & 1,153 & $-2,571$ & 1,145 & $-3,409$ & $-2,229$ \\
\hline 01080306061330109 & 1 & 1 & $-3,36$ & 21 & 7 & 0,683 & $-1,953$ & 0,929 & $-2,987$ & $-1,567$ \\
\hline 0108030320040 & 1 & 1 & $-2,79$ & 24 & 8 & 1,140 & $-1,461$ & 0,817 & $-2,541$ & $-0,915$ \\
\hline 0108030320022-3 & 1 & 1 & $-2,44$ & 27 & 9 & 0,623 & $-1,201$ & 0,747 & $-2,715$ & $-1,406$ \\
\hline 01080306912-1_2 & 1 & 1 & $-2,13$ & 30 & 10 & 0,752 & $-0,921$ & 0,697 & $-2,330$ & $-0,731$ \\
\hline 01080306061330104 & 1 & 1 & $-1,86$ & 33 & 11 & 0,691 & $-0,751$ & 0,661 & $-2,107$ & $-1,228$ \\
\hline 0108030610700-3 & 3 & 4 & $-1,28$ & 36 & 12 & 1,456 & $-0,293$ & 0,586 & $-1,082$ & 0,160 \\
\hline 0108030311017 & 0 & 1 & $-1,45$ & 39 & 13 & 1,315 & $-0,428$ & 0,556 & $-1,232$ & $-0,063$ \\
\hline 0108030610705-1 & 0 & 1 & $-1,60$ & 42 & 14 & 0,104 & $-0,630$ & 0,531 & $-1,366$ & $-1,371$ \\
\hline 0108030320069-1 & 1 & 1 & $-1,46$ & 43 & 15 & 1,276 & $-0,485$ & 0,519 & $-1,558$ & $-0,396$ \\
\hline 0108030320045 & 1 & 1 & $-1,32$ & 46 & 16 & 2,141 & $-0,383$ & 0,507 & $-1,444$ & $-0,777$ \\
\hline 0108030610352 & 1 & 1 & $-1,19$ & 49 & 17 & 0,399 & $-0,273$ & 0,497 & $-1,312$ & $-0,550$ \\
\hline 0108030320042 & 1 & 1 & $-1,06$ & 52 & 18 & 0,925 & $-0,206$ & 0,488 & $-1,164$ & $-1,098$ \\
\hline 01080306061330069-2 & 1 & 3 & $-1,14$ & 55 & 19 & 1,291 & $-0,363$ & 0,434 & $-0,897$ & $-0,500$ \\
\hline 01080306061330114 & 1 & 1 & $-1,04$ & 58 & 20 & 0,608 & $-0,297$ & 0,427 & $-1,112$ & $-0,898$ \\
\hline
\end{tabular}

Tabel A.8: Testforløbdata for elev 349294, profilområde 3

\begin{tabular}{|c|c|c|c|c|c|c|c|c|c|c|}
\hline Opgavenummer & Rigtige & Delsp. & Theta & Spnr. & Profilspnr. & Tid & theta-2017 & SEM-2017 & beta-DNT & beta- 2017 \\
\hline 010803000301241390-1 & 0 & 1 & 0,25 & 3 & 1 & 2,50 & $-1,30$ & 2,30 & 0,570 & $-0,275$ \\
\hline 01080306061330123 & 0 & 1 & 0,00 & 6 & 2 & 2,70 & $-1,80$ & 1,90 & 0,330 & $-0,116$ \\
\hline 010803060613262-4 & 0 & 1 & $-2,20$ & 9 & 3 & 2,50 & $-2,30$ & 1,80 & 0,036 & $-0,570$ \\
\hline 01080306912-1_2 & 0 & 1 & $-3,90$ & 12 & 4 & 1,80 & $-2,70$ & 1,70 & $-2,300$ & $-0,731$ \\
\hline 010803060613601-3 & 1 & 1 & $-3,10$ & 15 & 5 & 0,96 & $-2,10$ & 1,10 & $-3,400$ & $-2,229$ \\
\hline 01080306061330109 & 1 & 1 & $-2,50$ & 18 & 6 & 1,50 & $-1,60$ & 0,92 & $-3,000$ & $-1,567$ \\
\hline 0108030320040 & 1 & 1 & $-2,00$ & 21 & 7 & 1,90 & $-1,20$ & 0,81 & $-2,500$ & $-0,915$ \\
\hline 0108030320030 & 1 & 1 & $-1,60$ & 24 & 8 & 3,60 & $-1,00$ & 0,75 & $-1,900$ & $-1,309$ \\
\hline 0108030311006 & 1 & 1 & $-1,30$ & 27 & 9 & 2,80 & $-0,76$ & 0,70 & $-1,600$ & $-0,954$ \\
\hline 0108030311017 & 1 & 1 & $-0,98$ & 30 & 10 & 2,80 & $-0,49$ & 0,67 & $-1,200$ & $-0,063$ \\
\hline 01080306061340013-1 & 2 & 3 & $-0,78$ & 33 & 11 & 6,80 & $-0,41$ & 0,55 & $-0,950$ & $-0,689$ \\
\hline
\end{tabular}


Tabel A.8: Testforløbdata for elev 349294, profilområde 3 (continued)

\begin{tabular}{|c|c|c|c|c|c|c|c|c|c|c|}
\hline Opgavenummer & Rigtige & Delsp. & Theta & Spnr. & Profilspnr. & Tid & theta-2017 & SEM-2017 & beta-DNT & beta- 2017 \\
\hline 0108030320041 & 1 & 1 & $-0,61$ & 36 & 12 & 2,50 & $-0,31$ & 0,54 & $-0,740$ & $-0,814$ \\
\hline 010803000301238348-1 & 1 & 1 & $-0,44$ & 39 & 13 & 1,60 & $-0,24$ & 0,53 & $-0,550$ & $-1,280$ \\
\hline 01080303060910323 & 1 & 1 & $-0,28$ & 42 & 14 & 2,20 & $-0,13$ & 0,52 & $-0,420$ & $-0,404$ \\
\hline 010803000301241921-1 & 2 & 5 & $-0,31$ & 45 & 15 & 45,00 & $-0,33$ & 0,44 & $-0,019$ & $-0,487$ \\
\hline
\end{tabular}

Tabel A.9: Testforløbdata for elev 259724, profilområde 2

\begin{tabular}{|c|c|c|c|c|c|c|c|c|c|c|}
\hline Opgavenummer & Rigtige & Delsp. & Theta & Spnr. & Profilspnr. & Tid & theta-2017 & SEM-2017 & beta-DNT & beta- 2017 \\
\hline 0108020115072 & 0 & 1 & 1,50 & 2 & 1 & 0,43 & 0,032 & 2,20 & 1,90 & 1,377 \\
\hline 0108020110081-1 & 0 & 1 & 1,00 & 5 & 2 & 0,57 & $-0,850$ & 2,00 & 1,50 & 0,353 \\
\hline 0108020111011 & 0 & 1 & $-1,10$ & 8 & 3 & 2,90 & $-1,600$ & 1,80 & 0,94 & $-0,134$ \\
\hline 0108020110086-1 & 0 & 1 & $-2,70$ & 11 & 4 & 0,37 & $-2,200$ & 1,70 & $-1,10$ & $-0,597$ \\
\hline 0108020110172-1 & 1 & 1 & $-2,10$ & 14 & 5 & 0,46 & $-1,400$ & 1,10 & $-2,60$ & $-1,386$ \\
\hline 0108020115042 & 1 & 1 & $-1,40$ & 17 & 6 & 2,90 & $-0,980$ & 0,92 & $-2,00$ & $-1,020$ \\
\hline 0108020110147-1 & 1 & 1 & $-0,96$ & 20 & 7 & 1,50 & $-0,550$ & 0,82 & $-1,40$ & $-0,230$ \\
\hline 0108020111012 & 1 & 1 & $-0,55$ & 23 & 8 & 1,70 & $-0,250$ & 0,76 & $-0,91$ & $-0,336$ \\
\hline 0108020110190-1 & 1 & 1 & $-0,20$ & 26 & 9 & 1,40 & $-0,096$ & 0,72 & $-0,47$ & $-0,876$ \\
\hline 0108020110084-1 & 1 & 1 & 0,12 & 29 & 10 & 2,60 & 0,078 & 0,68 & $-0,10$ & $-0,527$ \\
\hline
\end{tabular}

Tabel A.10: Testforløbdata for elev 143590, profilområde 3

\begin{tabular}{|c|c|c|c|c|c|c|c|c|c|c|}
\hline Opgavenummer & Rigtige & Delsp. & Theta & Spnr. & Profilspnr. & Tid & theta- 2017 & SEM-2017 & beta-DNT & beta- 2017 \\
\hline 0108030320047-2 & 0 & 1 & 0,250 & 3 & 1 & 0,722 & $-1,146$ & 2,134 & 0,544 & 0,272 \\
\hline 01080306061330121 & 0 & 1 & 0,000 & 6 & 2 & 2,562 & $-1,454$ & 1,901 & 0,261 & 0,057 \\
\hline 01080306061330122 & 0 & 1 & $-2,253$ & 9 & 3 & 1,655 & $-1,983$ & 1,760 & 0,090 & $-0,263$ \\
\hline 01080306912-1_2 & 1 & 1 & $-1,727$ & 12 & 4 & 0,894 & $-1,088$ & 1,113 & $-2,330$ & $-0,731$ \\
\hline 0108030310024-3 & 1 & 1 & $-1,129$ & 15 & 5 & 1,065 & $-0,833$ & 0,954 & $-1,728$ & $-1,541$ \\
\hline 0108030610396 & 1 & 1 & $-0,696$ & 18 & 6 & 0,552 & $-0,573$ & 0,857 & $-1,150$ & $-1,118$ \\
\hline 01080303060910327 & 3 & 4 & $-0,262$ & 21 & 7 & 2,380 & $-0,365$ & 0,601 & $-0,549$ & $-0,718$ \\
\hline 010803000301241593-1 & 5 & 5 & 0,466 & 24 & 8 & 9,072 & 0,239 & 0,576 & $-0,065$ & $-0,466$ \\
\hline 01080306061340005-2 & 1 & 1 & 0,618 & 27 & 9 & 1,252 & 0,343 & 0,570 & 0,476 & $-0,493$ \\
\hline 01080303060940009-1 & 2 & 3 & 0,700 & 30 & 10 & 1,999 & 0,543 & 0,543 & 0,235 & 0,425 \\
\hline
\end{tabular}

Tabel A.11: Testforløbdata for elev 317854, profilområde 2

\begin{tabular}{|c|c|c|c|c|c|c|c|c|c|c|}
\hline Opgavenummer & Rigtige & Delsp. & Theta & Spnr. & Profilspnr. & Tid & theta-2017 & SEM-2017 & beta-DNT & beta- 2017 \\
\hline 0108020111018 & 1 & 1 & 2,5 & 2 & 1 & 0,18 & 1,8 & 2,50 & 2,1 & 1,017 \\
\hline 010802000301234810-1 & 1 & 1 & 3,0 & 5 & 2 & 0,56 & 2,9 & 1,90 & 2,6 & 1,433 \\
\hline 0108020111006 & 1 & 1 & 5,1 & 8 & 3 & 0,84 & 3,3 & 1,80 & 2,9 & 1,381 \\
\hline 010802000301239468-1 & 0 & 1 & 4,5 & 11 & 4 & 0,47 & 3,1 & 1,30 & 5,0 & 4,022 \\
\hline 0108020110231 & 0 & 1 & 3,9 & 14 & 5 & 0,65 & 2,5 & 1,00 & 4,5 & 2,768 \\
\hline 010802000301234818-1 & 0 & 1 & 3,5 & 17 & 6 & 0,39 & 2,3 & 0,93 & 4,1 & 3,185 \\
\hline 0108020110166-1 & 0 & 1 & 3,2 & 20 & 7 & 0,72 & 1,9 & 0,84 & 3,5 & 2,089 \\
\hline 0108020110268 & 0 & 1 & 2,9 & 23 & 8 & 0,23 & 1,7 & 0,79 & 3,3 & 2,251 \\
\hline 010802000301238021-1 & 1 & 1 & 3,2 & 26 & 9 & 0,25 & 1,9 & 0,73 & 3,0 & 1,323 \\
\hline 010802000301239338-1 & 1 & 1 & 3,5 & 29 & 10 & 0,44 & 2,2 & 0,69 & 3,7 & 2,922 \\
\hline 010802000301239337-1 & 0 & 1 & 3,3 & 32 & 11 & 0,65 & 2,1 & 0,67 & 3,7 & 3,363 \\
\hline 010802000301234958-1 & 0 & 1 & 3,2 & 35 & 12 & 0,32 & 2,1 & 0,65 & 4,0 & 3,872 \\
\hline 010802000301234959-1 & 0 & 1 & 2,9 & 38 & 13 & 0,49 & 1,9 & 0,62 & 2,8 & 1,985 \\
\hline 0108020110139-1 & 1 & 1 & 3,1 & 41 & 14 & 0,34 & 2,0 & 0,60 & 2,7 & 1,274 \\
\hline 010802000301234951-1 & 1 & 1 & 3,2 & 44 & 15 & 0,93 & 2,2 & 0,57 & 2,7 & 2,058 \\
\hline 010802000301234848-1 & 1 & 1 & 3,3 & 46 & 16 & 0,30 & 2,3 & 0,55 & 2,6 & 2,066 \\
\hline 0108020111019 & 1 & 1 & 3,4 & 49 & 17 & 0,37 & 2,4 & 0,53 & 2,6 & 1,370 \\
\hline 0108020111022 & 0 & 1 & 3,2 & 52 & 18 & 0,49 & 2,2 & 0,51 & 2,5 & 1,532 \\
\hline 0108020111026 & 1 & 1 & 3,3 & 55 & 19 & 0,46 & 2,2 & 0,50 & 2,3 & 0,837 \\
\hline 010802000301234814-1 & 0 & 1 & 3,1 & 58 & 20 & 0,28 & 2,1 & 0,49 & 2,3 & 2,154 \\
\hline
\end{tabular}


Tabel A.11: Testforløbdata for elev 317854, profilområde 2 (continued)

\begin{tabular}{|c|c|c|c|c|c|c|c|c|c|c|}
\hline Opgavenummer & Rigtige & Delsp. & Theta & Spnr. & Profilspnr. & Tid & theta-2017 & SEM-2017 & beta-DNT & beta- 2017 \\
\hline 010802000301234953-1 & 1 & 1 & 3,2 & 61 & 21 & 0,50 & 2,2 & 0,48 & 2,2 & 1,411 \\
\hline 0108020110266 & 1 & 1 & 3,2 & 64 & 22 & 0,37 & 2,2 & 0,47 & 2,2 & 0,544 \\
\hline 010802000301234788-1 & 1 & 1 & 3,3 & 67 & 23 & 0,60 & 2,3 & 0,46 & 2,2 & 1,338 \\
\hline 010802000301234941-1 & 0 & 1 & 3,1 & 70 & 24 & 0,39 & 2,1 & 0,45 & 2,2 & 1,359 \\
\hline 0108020110150-1 & 1 & 1 & 3,2 & 73 & 25 & 0,54 & 2,2 & 0,44 & 2,1 & 1,108 \\
\hline 0108020110083-1 & 0 & 1 & 3,1 & 76 & 26 & 1,40 & 2,1 & 0,43 & 2,1 & 1,275 \\
\hline 0108020111016 & 1 & 1 & 3,1 & 79 & 27 & 0,28 & 2,1 & 0,42 & 2,0 & 0,452 \\
\hline 010802000301234966-1 & 0 & 1 & 3,0 & 82 & 28 & 0,44 & 2,0 & 0,41 & 2,0 & 1,346 \\
\hline 0108020115072 & 0 & 1 & 2,9 & 85 & 29 & 0,39 & 1,9 & 0,40 & 1,9 & 1,377 \\
\hline 0108020111032 & 0 & 1 & 2,8 & 88 & 30 & 0,67 & 1,8 & 0,40 & 1,9 & 0,266 \\
\hline 0108020110027-1 & 0 & 1 & 2,6 & 91 & 31 & 0,49 & 1,7 & 0,39 & 1,8 & 1,486 \\
\hline 0108020111024 & 0 & 1 & 2,5 & 94 & 32 & 0,39 & 1,6 & 0,38 & 1,8 & 0,382 \\
\hline
\end{tabular}

Tabel A.12: Testforløbdata for elev 219768, profilområde 2

\begin{tabular}{|c|c|c|c|c|c|c|c|c|c|c|}
\hline Opgavenummer & Rigtige & Delsp. & Theta & Spnr. & Profilspnr. & Tid & theta-2017 & SEM-2017 & beta-DNT & beta-2017 \\
\hline 0108020111018 & 1 & 1 & 2,5 & 2 & 1 & 0,30 & 1,8 & 2,50 & 2,1 & 1,02 \\
\hline 010802000301234810-1 & 1 & 1 & 3,0 & 5 & 2 & 0,87 & 2,9 & 1,90 & 2,6 & 1,43 \\
\hline 0108020111006 & 1 & 1 & 5,1 & 8 & 3 & 0,92 & 3,3 & 1,80 & 2,9 & 1,38 \\
\hline 010802000301239468-1 & 1 & 1 & 6,6 & 11 & 4 & 0,53 & 5,2 & 2,00 & 5,0 & 4,02 \\
\hline 010802000301234973-1 & 1 & 1 & 7,0 & 14 & 5 & 1,10 & 5,7 & 1,80 & 6,1 & 3,87 \\
\hline 010802000301234885-1 & 0 & 1 & 7,0 & 17 & 6 & 1,60 & 4,6 & 1,10 & 8,0 & 3,90 \\
\hline 010802000301234876-1 & 0 & 1 & 6,0 & 20 & 7 & 0,72 & 3,9 & 0,93 & 4,7 & 2,96 \\
\hline 010802000301239469-1 & 0 & 1 & 5,3 & 23 & 8 & 0,61 & 3,5 & 0,83 & 4,7 & 3,62 \\
\hline 0108020110231 & 0 & 1 & 4,8 & 26 & 9 & 1,30 & 3,1 & 0,76 & 4,5 & 2,77 \\
\hline 010802000301234818-1 & 0 & 1 & 4,4 & 29 & 10 & 1,30 & 2,9 & 0,72 & 4,1 & 3,19 \\
\hline 010802000301234958-1 & 0 & 1 & 4,1 & 32 & 11 & 0,32 & 2,8 & 0,69 & 4,0 & 3,87 \\
\hline 010802000301239338-1 & 0 & 1 & 3,8 & 35 & 12 & 0,44 & 2,6 & 0,66 & 3,7 & 2,92 \\
\hline 010802000301239337-1 & 0 & 1 & 3,6 & 38 & 13 & 0,78 & 2,5 & 0,64 & 3,7 & 3,36 \\
\hline 0108020110166-1 & 0 & 1 & 3,4 & 41 & 14 & 0,72 & 2,3 & 0,62 & 3,5 & 2,09 \\
\hline 0108020110268 & 0 & 1 & 3,2 & 44 & 15 & 0,31 & 2,1 & 0,60 & 3,3 & 2,25 \\
\hline
\end{tabular}

Tabel A.13: Testforløbdata for elev 305503, profilområde 3

\begin{tabular}{|c|c|c|c|c|c|c|c|c|c|c|}
\hline Opgavenummer & Rigtige & Delsp. & Theta & Spnr. & Profilspnr. & Tid & theta-2017 & SEM-2017 & beta-DNT & beta- 2017 \\
\hline 01080306061330075 & 1 & 1 & 0,75 & 3 & 1 & 1,7 & 1,00 & 2,50 & 0,51 & 0,269 \\
\hline 01080306061330078 & 1 & 1 & 1,00 & 6 & 2 & 4,1 & 1,70 & 1,90 & 0,73 & $-0,015$ \\
\hline 010803000301238868-1 & 1 & 1 & 3,30 & 9 & 3 & 4,6 & 2,80 & 1,80 & 0,93 & 1,482 \\
\hline 010803000301235585-2 & 0 & 1 & 2,80 & 12 & 4 & 3,0 & 2,30 & 1,30 & 3,40 & 2,855 \\
\hline 010803000301235768-1 & 0 & 1 & 2,20 & 15 & 5 & 9,7 & 1,70 & 1,00 & 2,80 & 1,833 \\
\hline 010803000301235607-2 & 0 & 1 & 1,70 & 18 & 6 & 5,6 & 1,20 & 0,90 & 2,00 & 1,100 \\
\hline 010803000301238349-1 & 0 & 1 & 1,30 & 21 & 7 & 3,0 & 1,00 & 0,83 & 1,60 & 1,721 \\
\hline 010803000301238838-1 & 0 & 1 & 1,00 & 24 & 8 & 4,4 & 0,88 & 0,79 & 1,40 & 2,135 \\
\hline 01080306910-1_2 & 0 & 1 & 0,76 & 27 & 9 & 2,7 & 0,68 & 0,75 & 1,10 & 1,224 \\
\hline 010803000301236033-2 & 0 & 1 & 0,52 & 30 & 10 & 4,0 & 0,40 & 0,73 & 0,86 & 0,398 \\
\hline 010803000301237450-3 & 0 & 1 & 0,29 & 33 & 11 & 4,1 & 0,19 & 0,71 & 0,60 & 0,645 \\
\hline
\end{tabular}

Tabel A.14: Testforløbdata for elev 386356, profilområde 1

\begin{tabular}{|c|c|c|c|c|c|c|c|c|c|c|}
\hline Opgavenummer & Rigtige & Delsp. & Theta & Spnr. & Profilspnr. & Tid & theta-2017 & SEM-2017 & beta-DNT & beta- 2017 \\
\hline 0108010420130 & 1 & 1 & 1,000 & 1 & 1 & & 2,500 & 2,10 & 0,460 & 1,107 \\
\hline 010801000301238556-1 & 1 & 1 & 1,500 & 4 & 2 & 0,42 & 2,800 & 1,90 & 1,100 & 1,346 \\
\hline 010801000301234839-1 & 1 & 1 & 3,600 & 7 & 3 & 0,57 & 3,300 & 1,80 & 1,500 & 1,591 \\
\hline 0108010410315 & 0 & 1 & 2,800 & 10 & 4 & 0,63 & 2,000 & 1,10 & 3,000 & 0,201 \\
\hline 010801000301239196-1 & 0 & 1 & 2,200 & 13 & 5 & 0,31 & 1,700 & 0,96 & 2,400 & 2,383 \\
\hline
\end{tabular}


Tabel A.14: Testforløbdata for elev 386356, profilområde 1 (continued)

\begin{tabular}{|c|c|c|c|c|c|c|c|c|c|c|}
\hline Opgavenummer & Rigtige & Delsp. & Theta & Spnr. & Profilspnr. & Tid & theta-2017 & SEM-2017 & beta-DNT & beta- 2017 \\
\hline 010801000301234841-1 & 0 & 1 & 1,800 & 16 & 6 & 0,32 & 1,300 & 0,86 & 2,200 & 0,865 \\
\hline 0108010410094 & 0 & 1 & 1,500 & 19 & 7 & 0,36 & 0,930 & 0,79 & 1,800 & 0,859 \\
\hline 0108010420122 & 0 & 1 & 1,200 & 22 & 8 & 0,45 & 0,700 & 0,75 & 1,500 & 1,157 \\
\hline 0108010420160 & 0 & 1 & 0,910 & 25 & 9 & 0,57 & 0,580 & 0,72 & 1,200 & 1,684 \\
\hline 010801000301238872-1 & 0 & 1 & 0,670 & 28 & 10 & 0,19 & 0,410 & 0,70 & 1,000 & 1,072 \\
\hline 0108010415120 & 0 & 1 & 0,440 & 31 & 11 & 0,19 & 0,310 & 0,68 & 0,700 & 1,580 \\
\hline 010801000301238996-1 & 0 & 1 & 0,210 & 34 & 12 & 0,35 & 0,098 & 0,67 & 0,450 & 0,295 \\
\hline 010801000301238353-1 & 0 & 1 & $-0,015$ & 37 & 13 & 0,66 & $-0,120$ & 0,67 & 0,230 & $-0,070$ \\
\hline 0108010420142 & 0 & 1 & $-0,230$ & 40 & 14 & 0,38 & $-0,240$ & 0,65 & 0,068 & 0,688 \\
\hline 0108010420150 & 0 & 1 & $-0,430$ & 43 & 15 & 0,38 & $-0,430$ & 0,65 & $-0,130$ & $-0,073$ \\
\hline 0108010415129 & 0 & 1 & $-0,640$ & 45 & 16 & 0,52 & $-0,670$ & 0,65 & $-0,370$ & $-0,862$ \\
\hline 0108010410230009 & 0 & 1 & $-0,850$ & 47 & 17 & 0,31 & $-0,790$ & 0,65 & $-0,570$ & 0,080 \\
\hline 010801000301238279-1 & 1 & 1 & $-0,650$ & 48 & 18 & 0,51 & $-0,650$ & 0,60 & $-0,780$ & $-1,076$ \\
\hline 0108010420027 & 0 & 1 & $-0,820$ & 49 & 19 & 0,42 & $-0,830$ & 0,59 & $-0,620$ & $-0,731$ \\
\hline 0108010440028 & 1 & 1 & $-0,660$ & 50 & 20 & 0,28 & $-0,690$ & 0,55 & $-0,810$ & $-0,924$ \\
\hline 0108010415182 & 0 & 1 & $-0,800$ & 51 & 21 & 0,20 & $-0,860$ & 0,55 & $-0,630$ & $-0,964$ \\
\hline 0108010410230021 & 1 & 1 & $-0,660$ & 52 & 22 & 0,36 & $-0,710$ & 0,52 & $-0,730$ & $-0,590$ \\
\hline
\end{tabular}

Tabel A.15: Testforløbdata for elev 439773, profilområde 2

\begin{tabular}{|c|c|c|c|c|c|c|c|c|c|c|}
\hline Opgavenummer & Rigtige & Delsp. & Theta & Spnr. & Profilspnr. & Tid & theta-2017 & SEM-2017 & beta-DNT & beta- 2017 \\
\hline 0108020111016 & 1 & 1 & 2,5 & 2 & 1 & 1,30 & 1,9 & 2,10 & 2,0 & 0,452 \\
\hline 0108020111022 & 1 & 1 & 3,0 & 5 & 2 & 1,70 & 2,8 & 2,00 & 2,5 & 1,532 \\
\hline 0108020111006 & 1 & 1 & 5,1 & 8 & 3 & 0,59 & 3,2 & 1,80 & 2,9 & 1,381 \\
\hline 010802000301239468-1 & 1 & 1 & 6,6 & 11 & 4 & 1,30 & 5,2 & 2,00 & 5,0 & 4,022 \\
\hline 010802000301234973-1 & 0 & 1 & 5,8 & 14 & 5 & 1,70 & 4,1 & 1,20 & 6,1 & 3,868 \\
\hline 010802000301234876-1 & 0 & 1 & 4,9 & 17 & 6 & 0,76 & 3,3 & 1,00 & 4,7 & 2,956 \\
\hline 010802000301239469-1 & 0 & 1 & 4,4 & 20 & 7 & 1,00 & 3,0 & 0,90 & 4,7 & 3,618 \\
\hline 0108020110231 & 0 & 1 & 4,1 & 23 & 8 & 2,20 & 2,7 & 0,83 & 4,5 & 2,768 \\
\hline 010802000301234818-1 & 0 & 1 & 3,8 & 26 & 9 & 0,86 & 2,5 & 0,77 & 4,1 & 3,185 \\
\hline 010802000301234958-1 & 0 & 1 & 3,6 & 29 & 10 & 0,95 & 2,4 & 0,75 & 4,0 & 3,872 \\
\hline 010802000301239337-1 & 0 & 1 & 3,3 & 32 & 11 & 0,55 & 2,2 & 0,72 & 3,7 & 3,363 \\
\hline 0108020110166-1 & 0 & 1 & 3,1 & 35 & 12 & 0,74 & 2,0 & 0,69 & 3,5 & 2,089 \\
\hline 0108020110268 & 0 & 1 & 2,9 & 38 & 13 & 0,38 & 1,8 & 0,67 & 3,3 & 2,251 \\
\hline $010802000301238021-1$ & 0 & 1 & 2,7 & 41 & 14 & 0,61 & 1,6 & 0,66 & 3,0 & 1,323 \\
\hline 010802000301234959-1 & 0 & 1 & 2,5 & 43 & 15 & 1,20 & 1,4 & 0,64 & 2,8 & 1,985 \\
\hline 0108020111019 & 0 & 1 & 2,4 & 45 & 16 & 0,60 & 1,2 & 0,63 & 2,6 & 1,370 \\
\hline 010802000301234951-1 & 0 & 1 & 2,2 & 47 & 17 & 0,26 & 1,1 & 0,61 & 2,7 & 2,058 \\
\hline 010802000301234814-1 & 0 & 1 & 2,0 & 49 & 18 & 0,68 & 1,0 & 0,60 & 2,3 & 2,154 \\
\hline 0108020111018 & 1 & 1 & 2,2 & 51 & 19 & 0,18 & 1,2 & 0,56 & 2,1 & 1,017 \\
\hline 010802000301234953-1 & 1 & 1 & 2,3 & 53 & 20 & 0,46 & 1,3 & 0,53 & 2,2 & 1,411 \\
\hline 010802000301234810-1 & 1 & 1 & 2,5 & 57 & 21 & 1,00 & 1,5 & 0,51 & 2,6 & 1,433 \\
\hline 010802000301234848-1 & 1 & 1 & 2,6 & 60 & 22 & 0,34 & 1,6 & 0,48 & 2,6 & 2,066 \\
\hline 0108020110139-1 & 1 & 1 & 2,7 & 63 & 23 & 0,18 & 1,7 & 0,47 & 2,7 & 1,274 \\
\hline
\end{tabular}




\section{Analyse af person-fit baseret på 2017-sværhedsgrader}

\section{B.1 Indledning}

Dette appendiks gengiver analyser af en række enkeltstående testforløb. Bortset fra et af de test der benyttes til at afprøve tilpasningen mellem testforløbene og Rasch-modellen, har de metoder der benyttes til analyserne, været en del af teorien for Rasch-modeller siden starten at 70'erne. På den anden side er de metoder vi bruger til afprøvningen af tilpasningen mellem enkeltstående testforløb og Rasch-modellen, så vidt vi ved kun implementeret i det program, DIGRAM, som er benyttet til analyserne i dette bilag, og endda kun delvist beskrevet i brugervejledningen til programmet. Af den grund indleder vi dette appendiks med et afsnit der beskriver metoderne, således at andre der måtte have brug for det, selv kan implementere metoderne og kontrollere resultaterne.

I det efter følgende antages det at $A=\left\{X_{1},, X_{k}\right\}$ er en mængde af items fra en Rasch-model. Items kan både være dikotome eller polytome. $x=\left(x_{1},, x_{k}\right)$ er en vektor af item-responser. Sådanne vektorer omtales i det efterfølgende som responsmønstre.

Rasch-modellen antager at responserne er stokastisk uafhængige med sandsynligheder givet ved

$$
\operatorname{Prob}\left(X_{i}=x\right)=\frac{\exp \left(x \theta-\sum_{j=1}^{x_{i}} \beta_{i j}\right)}{\sum_{z=0}^{m_{i}} \exp \left(z \theta-\sum_{j=1}^{z} \beta_{i j}\right)}
$$

I formel (B.1) er $\theta$ en såkaldt person-parameter der angiver hvor dygtig eleven er. $\beta$-parametrene er itemparametre. Item-parametrene omtales som regel som sværhedsgrader når der er tale om dikotome items, og som tærskel-værdier, når der er tale om polytome items. Tallet $m_{i}$ er lig med den maksimale score som en elev kan opnå på det pågældende item. For dikotome items, hvor der kun skelnes mellem rigtige og forkerte svar, er $m=1$ og $\beta_{i 1}$ omtales som opgavens sværhedsgrad, men $m$ kan være større hvis resultatet af opgaven vurderes på en gradueret skala fra nul til $\mathrm{m}$.

Tærskelværdierne er defineret fra værdien $X_{i}=1$ op til værdien $X_{i}=m$. Når der er tale om dikotome items hvor der kun er én item-parameter, nøjes man med at omtale sværhedsgraden som $\beta_{i}$ uden henvisning til at det er en tærskelværdi der svarer til $X_{i}=1$. Det er i forbindelse med det efterfølgende bekvemt at indføre en ekstra "tærskelværdi", $\beta_{i 0}$, der altid antages at være lig med 0 således at $\sum_{j=1}^{x} \beta_{i j}=\sum_{j=0}^{x} \beta_{i j}$ og således at antallet af item-parametre for både dikotome og polytome items er lig med $m_{i}+1$.

I Rasch-modellen er den samlede score, $R=\sum_{1}^{k} X_{i}$, statistisk sufficient for personparameteren fordi den betingede fordeling af svarmønstret givet den samlede score, $R=r$, ikke afhænger af den ukendte personparameter, $\theta$.

For at undersøge om et bestemt svarmønster passer til Rasch-modellen, skal man undersøge om der er et eller andet overraskende og grænsende til usandsynligt ved svarmønstret i forhold til det Rasch-modellen ville 
forvente. I den forbindelse er den statistiske sufficiens en særdeles bekvem egenskab fordi den betyder at vi kan unders $\varnothing$ ge om svarmønstret er mere eller mindre usandsynligt, ved at beregne den betingede sandsynlighed for svarmønstret givet den samlede score uden at inddrage estimater af den ukendte personparameter.

I forbindelse med afprøvningen af tilpasningen mellem Rasch-modellen og svarmønstrene for enkelte elever har vi beregnet tre forskellige typer af betingede sandsynligheder, der på hver sin måde kan fortælle om et svarmønster - set fra Rasch-modellens synsvinkel - er overraskende og dermed udtryk for signifikant evidens mod tilpasningen.

Den første er den betingede sandsynlighed for det samlede svarmønster givet den samlede score,

$$
\operatorname{Prob}\left(X_{1}=x_{1}, X_{2}=x_{2}, \ldots, X_{m}=x_{m} \mid R=r\right)=\frac{\operatorname{Prob}\left(X_{1}=x_{1}, X_{2}=x_{2}, \ldots, X_{m}=x_{m}\right)}{\operatorname{Prob}(R=r)}
$$

Idet svarmønstrets tilpasning til Rasch-modellen forkastes hvis denne sandsynlighed er overraskende lille.

Da antallet af mulige svarmønstre med en givet samlet score kan være meget stort, og da summen sandsynlighederne for samtlige svarmønstre altid er lig med 1, må man forvente at de fleste eller måske alle betingede sandsynligheder er relativt små. For at tage stilling til om det observerede svarmønster afviger signifikant fra det Rasch-modellen forventer, beregnes derfor en såkaldt p-værdi der er givet som summen af sandsynlighederne for alle de svarmønstre der har samme eller endnu mindre sandsynlighed for at forekomme som det observerede svarmønster.

Formel (B.1) parametricerer Rasch-modellen som en såkaldt partial credit-model (PCM). Denne parametricering er populær fordi den placerer Rasch-modellen som et medlem af familien af item-responsmodeller, men parametriceringen er særdeles ubekvem hvis man vil udlede formler der gør det mulig at beregne de betingede sandsynligheder. De efterfølgende formler viser hvorledes man kan reformulere modellen således at formlerne både bliver mere læsbare og lettere at skrive op.

I det første skridt indføres nye item-parametre defineret ved $\sigma_{i x}=-\sum_{j=1}^{x} \beta_{i j}$ hvorefter PCM-formlen (B.1) omskrives til

$$
\operatorname{Prob}\left(X_{i}=x\right)=\frac{\exp \left(x \theta+\sigma_{i x}\right)}{\sum_{z=0}^{m_{i}} \exp \left(z \theta+\sigma_{i z}\right)}
$$

For yderligere at forenkle formlerne er det herefter bekvemt at sætte $\delta_{i x}=\exp \left(\sigma_{i x}\right)$ således at (B.3) reduceres til

$$
\operatorname{Prob}\left(X_{i}=x\right)=\frac{\exp (x \theta) \delta_{i x}}{\sum_{z=0}^{m_{i}} \exp (z \theta) \delta_{i z}}
$$

Med denne parametricering er det relativt let at se, at fordelingen af svarmønstret er givet ved sandsynlighederne

$$
\operatorname{Prob}\left(X_{1}=x_{1}, X_{2}=x_{2}, \ldots, X_{m}=x_{m}\right)=\frac{\exp (r \theta) \prod_{i=1}^{k} \delta_{i x_{i}}}{G(\theta)}
$$

hvor $r=\sum_{i=1}^{k} x_{i x_{i}}$ og $G(\theta)=\sum_{x=\left(x_{i}, \ldots, x_{k}\right)}\left(\exp (r \theta) \prod_{i=1}^{k} \delta_{i x_{i}}\right)$ samt at sandsynligheden for at den samlede score lig med $\mathrm{r}$ er lig med 


$$
\operatorname{Prob}(R=r)=\sum_{\left(x_{1}, \ldots x_{k}\right): r=\sum_{i} x_{i}} \operatorname{Prob}\left(X_{1}=x_{1}, X_{2}=x_{2}, \ldots, X_{m}=x_{m}\right)=\frac{\exp (r \theta)}{G(\theta)} \sum_{\left(x_{1}, \ldots x_{k}\right): r=\sum_{i} x_{i}} \prod_{i} \delta_{i x}
$$

Hvis man derefter sætter $\gamma_{r}=\sum_{\left(x_{1}, \ldots x_{k}\right): r=\sum_{i} x_{i}} \prod_{i} \delta_{i x}$ får man den formel for fordelingen af den samlede score over et sæt af items fra en Rasch-model som Rasch (1960) benyttede da teorien for Rasch-modellen blev defineret

$$
\operatorname{Prob}(R=r)=\frac{\exp (r \theta) \gamma_{r}}{G(\theta)}
$$

Hvorefter den betingede sandsynlighed for et bestemt svarmønster, $\left(x_{1}, x_{k}\right)$, er lig med

$$
\operatorname{Prob}\left(X_{1}=x_{1}, X_{2}=x_{2}, \ldots, X_{m}=x_{m} \mid R=r\right)=\frac{\prod_{i=1}^{k} \delta_{i x_{i}}}{\gamma_{r}}
$$

Hvis der kun er tale om dikotome items, omtales $\gamma_{r}$ som det symmetriske polynomium af orden r. Med polytome items er dette ikke helt korrekt, men teorien for Rasch-modeller omtaler alligevel værdierne som gamma-polynomier.

I det foregående er gamma-polynomierne beregnet for hele mængden, A, af items, men polynomierne kan naturligvis beregnes for alle delmængder af items. Hvis man vil udlede formler hvor der optræder gammapolynomier for delmængde af items, er det nødvendigt at formulere det således at man kan se, hvilke delmængder der er tale om. Hvis $B \subset A$ er en delmængde af items omtales gamma-polynomiet over disse items som $\gamma_{r}(B)$.

Dette får vi brug for i forbindelse med de næste to sandsynligheder som bruges til at afprøve om der er tilpasning mellem et konkret svarmønster og Rasch-modellen.

Den betingede fordeling af et enkelt item givet den samlede score på r er givet ved

$$
\operatorname{Prob}\left(X_{i}=x_{i} \mid R=r\right)=\frac{\delta_{i x_{i}} \gamma_{r-x_{i}}\left(A \backslash X_{i}\right)}{\gamma_{r}}
$$

Disse sandsynligheder beregnes rutinemæssigt for samtlige items og kan i specielle tilfælde hvor der svares forkert på meget lette items eller korrekt på meget vanskelige items, afsløre at tilpasningen mellem svarmønstret og Rasch-modellen er utilstrækkeligt. Hvis det drejer sig om adaptive test vil algoritmen have udvalgt opgaver hvor der er ca. 50 procents chance for et korrekt svar - hvis sværhedsgraderne er korrekte og den adaptive algoritme fungerer efter hensigten. I sådanne tilfælde kan der ikke være små sandsynligheder for enkelte items, og samtlige svarmønstre vil have næste samme sandsynligheder for at forekomme. Sandsynlighederne (B.8) og (B.9) definerer derfor test med relativt begrænset styrke med mindre der ligefrem er fejl i forudsætningerne for den adaptive algoritme. Af den grund har vi udvidet testene baseret på (B.8) og (B.9) med test baseret på den samlede score i starten af forløbet.

Lad derfor $A_{i}=\left\{X_{1}, . ., X_{i}\right\}$ være de første $i$ opgaver og lad $R_{i}$ være den samlede score over disse items.

Den betingede fordeling af $R_{i}$ givet $R$ er givet ved følgende sandsynligheder,

$$
\operatorname{Prob}\left(R_{i}=r_{i} \mid R=r\right)=\frac{\gamma_{r_{i}}\left(A_{i}\right) \gamma_{r-r_{i}}\left(A \backslash A_{i}\right)}{\gamma_{r}}
$$


For at teste om der er signifikant få eller signifikant mange korrekte svar i forbindelse med de første $i$ opgaver, beregnes herefter to kumulerede sandsynligheder - to p-værdier - for udfald af $R_{i}$ henholdsvis op til og op fra den observerede $r_{i}$ værdi $P_{i}=\sum_{x \leq r_{i}} \operatorname{Prob}\left(R_{i}=x \mid R=r\right)$ og $Q_{i}=\sum_{x \geq r_{i}} \operatorname{Prob}\left(R_{i}=x \mid R=r\right)$ hvorefter tilpasningen til Rasch-modellen forkastes, hvis $p_{i}$ eller $q_{i}$ er mindre end 0,025.

\section{B.2 Resultater}

Tabel B1 opsummerer resultaterne af tests af tilpasningen mellem forløbene og Rasch-modellen inklusive beregninger af de betingede sandsynligheder af de samlede forløb (søjle 2 og 3), af de enkelte items (søjle 4) og af vurderinger af starten af forløbet (søjle 5).

Tabel B1. Tests af tilpasning mellem svarmønstre og Rasch-modellen for 15 elever. Søjle 2 angiver den betingede sandsynlighed (8) for det samlede svarmønster. P-værdien knyttet til denne sandsynlighed ses i søjle 3. Søjle 4 viser sandsynligheden (9) for det item med den mindste sandsynlighed for det observerede udfald, mens søjle 5 viser den mindste $p_{i}$ - eller $q_{i}$-værdi der er observeret for eleven.

\begin{tabular}{|c|c|c|c|c|}
\hline Person & $\begin{array}{l}\text { Response vector } \\
\text { Conditional probability }\end{array}$ & p-value & $\begin{array}{l}\text { Item } \\
\mathrm{p}\end{array}$ & $\begin{array}{l}\text { Subscore } \\
\mathrm{p}\end{array}$ \\
\hline 41985 & 0.00009287364475177000 & 0.254 & 0.2381 & 0.1567 \\
\hline 21613 & 0.00001789260290787000 & 0.250 & 0.1419 & 0.0001 \\
\hline 29172 & 0.00000000000000200000 & 0.725 & 0.1862 & 0.0050 \\
\hline 104649 & 0.00000577202527575000 & 0.493 & 0.1048 & 0.0063 \\
\hline 49294 & 0.00038242827130304000 & 0.979 & 0.2304 & 0.0299 \\
\hline 59724 & 0.02372005293312173000 & 0.957 & 0.3073 & 0.0237 \\
\hline 143590 & 0.00293881490003593000 & 0.838 & 0.2372 & 0.0268 \\
\hline 428314 & 0.00140118668466098000 & 0.963 & 0.1711 & 0.0590 \\
\hline 19768 & 0.00076454121996100000 & 0.359 & 0.1098 & 0.0008 \\
\hline 387213 & 0.11073991341957229000 & 0.796 & 0.3222 & 0.1107 \\
\hline 439773 & 0.00002241574544920000 & 0.611 & 0.0800 & 0.0137 \\
\hline 305503 & 0.02131733610277121000 & 0.748 & 0.1963 & 0.0213 \\
\hline 386356 & 0.00000524481047458000 & 0.071 & 0.0774 & 0.0005 \\
\hline 341070 & 0.00175769063066167000 & 0.907 & 0.3395 & 0.1473 \\
\hline 17854 & 0.00000001464366035000 & 0.397 & 0.1871 & 0.0025 \\
\hline
\end{tabular}

Da der er tale om adaptive test, kan der som forventet ikke påvises signifikante afvigelser fra de samlede forløb og for de enkelte opgaver. I elleve ud af femten tilfælde afviger starten på testforløbene fra det man ville forvente, hvis Rasch-modellen var gældende fra start til slut.

De hyppigste afvigelser fra Rasch-modellen i starten af testforløbet ses i tilfælde, hvor der startes med påfaldende mange fejl, hvorefter testadfærden tilsyneladende svarer til det Rasch-modellen ville forvente. Som konsekvens af dette er der i disse tilfælde foretaget nye beregninger af dygtigheden, hvor den mislykkede start på forløbene er blevet fraregnet. Resultatet af disse beregninger kan ses i tabel B2.

Tabel B2. WML estimater af dygtigheden baseret på korrekte 2017 sværhedsgrader (søjle 4) med eksakte beregninger af usikkerheden (søjle 5). I de tilfælde, hvor dele af forløbet tilsyneladende er mislykket er dygtigheden beregnet ud fra den del af forløbet, hvor testadfærden passer til Rasch-modellen. Disse tal ses i søjle 6 og 7. Den sidste søjle viser korrelationen mellem det aktuelle estimat af dygtigheden og sværhedsgraden af den efterfølgende opgave. 


\begin{tabular}{|c|c|c|c|c|c|c|c|}
\hline Person & Score & $\max$ & $\begin{array}{l}\text { All i } \\
\text { WML }\end{array}$ & $\begin{array}{r}\text { items } \\
\text { SEM }\end{array}$ & $\begin{array}{l}\text { Item } \\
\text { WML }\end{array}$ & $\begin{array}{l}\text { subset } \\
\text { SEM }\end{array}$ & $\begin{array}{l}\text { Person-Item } \\
\text { correlation }\end{array}$ \\
\hline 441985 & 9 & 17 & 1.88 & 0.51 & & & 0.59 \\
\hline 421613 & 13 & 21 & -0.63 & 0.44 & 0.93 & 0.79 & 0.64 \\
\hline 129172 & 38 & 61 & 0.46 & 0.28 & 0.70 & 0.30 & 0.73 \\
\hline 104649 & 15 & 25 & -0.30 & 0.43 & 0.32 & 0.56 & 0.69 \\
\hline 349294 & 13 & 21 & -0.33 & 0.44 & 0.20 & 0.56 & 0.71 \\
\hline 259724 & 6 & 10 & 0.08 & 0.69 & & & 0.67 \\
\hline 143590 & 14 & 19 & 0.54 & 0.55 & 1.33 & 0.74 & 0.67 \\
\hline 428314 & 18 & 25 & 0.79 & 0.51 & & & 0.86 \\
\hline 219768 & 5 & 15 & 2.10 & 0.61 & -0.11 & 0.68 & 0.71 \\
\hline 387213 & 4 & 10 & 2.03 & 0.76 & & & 0.86 \\
\hline 439773 & 9 & 23 & 1.70 & 0.47 & 1.17 & 0.56 & 0.78 \\
\hline 305503 & 3 & 11 & 0.19 & 0.72 & -1.62 & 0.71 & 0.79 \\
\hline 386356 & 6 & 22 & -0.71 & 0.52 & -1.57 & 0.66 & 0.80 \\
\hline 341070 & 9 & 17 & 2.36 & 0.54 & & & 0.65 \\
\hline 317854 & 15 & 32 & 1.56 & 0.38 & & & 0.64 \\
\hline
\end{tabular}

Alle sandsynlighederne i tabel B1 og B2 er baseret på estimaterne af sværhedsgrader i 2017. Den efterfølgende tabel B3 viser resultater hvis DNT's item-parametre havde været benyttet. Bemærk at usikkerheden på estimaterne i tabel B3 ikke er påfaldende bedre end i tabel 2, men at korrelationen mellem de personparametre, der estimeres undervejs, og sværhedsgraderne af de efterfølgende opgaver er væsentlig højere end i tabel 2. Den adaptive algoritme fungerer som den skal, men gevinsten er tilsyneladende begrænset.

Tabel B3. WML estimater af dygtigheden baseret på de sværhedsgrader som DNT benytter.

\begin{tabular}{|c|c|c|c|c|c|c|c|}
\hline Person & Score & $\max$ & $\begin{array}{l}\text { All } \\
\text { WML }\end{array}$ & $\begin{array}{r}\text { items } \\
\text { SEM }\end{array}$ & $\begin{array}{l}\text { Item } \\
\text { WML }\end{array}$ & $\begin{array}{l}\text { subset } \\
\text { SEM }\end{array}$ & $\begin{array}{l}\text { Person-Item } \\
\text { correlation }\end{array}$ \\
\hline 441985 & 9 & 17 & 2.88 & 0.50 & & & 0.82 \\
\hline 421613 & 13 & 21 & -1.60 & 0.46 & -0.16 & 0.78 & 0.82 \\
\hline 129172 & 38 & 61 & 0.99 & 0.28 & 1.25 & 0.30 & 0.90 \\
\hline 104649 & 15 & 25 & -1.05 & 0.44 & -0.50 & 0.54 & 0.94 \\
\hline 349294 & 13 & 21 & -0.32 & 0.45 & 0.09 & 0.55 & 0.98 \\
\hline 259724 & 6 & 10 & 0.07 & 0.78 & & & 0.90 \\
\hline 143590 & 14 & 19 & 0.64 & 0.52 & 1.27 & 0.70 & 1.00 \\
\hline 428314 & 18 & 25 & 0.85 & 0.46 & 1.35 & 0.57 & 1.00 \\
\hline 219768 & 5 & 15 & 3.23 & 0.61 & 0.95 & 0.68 & 0.92 \\
\hline 387213 & 4 & 10 & 2.38 & 0.79 & & & 1.00 \\
\hline 439773 & 9 & 23 & 2.74 & 0.47 & 2.16 & 0.56 & 0.97 \\
\hline 305503 & 3 & 11 & 0.37 & 0.71 & -1.46 & 0.70 & 1.00 \\
\hline 386356 & 6 & 22 & -0.62 & 0.52 & -1.44 & 0.66 & 0.99 \\
\hline 341070 & 9 & 17 & 3.38 & 0.52 & & & 0.73 \\
\hline 317854 & 15 & 32 & 2.55 & 0.38 & & & 0.76 \\
\hline
\end{tabular}

De efterfølgende sider indeholder forholdsvis uredigeret output fra analyserne, hvor man kan finde alle detaljer, inklusive de person-parametre der estimeres undervejs i forløbet, og sværhedsgrader for de opgaver som den adaptive rutine derefter vælger. For at hjælpe læseren er outputtet kommenteret for de første to elever, hvorefter vi håber at læseren selv kan gennemskue indholdet for de фvrige elever.

Den første tabel viser hvilke opgaver eleven har besvaret, om svaret var rigtigt (1) eller forkert (0) og hvor mange rigtige svar, der efterhånden samles op. Den sidste søjle med de såkaldte PCM thresholds angiver opgavernes sværhedsgrader. Eleven besvarer 9 ud af 17 dikotome opgaver korrekt.

Det er dette resultat, der benyttes til at beregne dygtigheden målt på Rasch-modellens logit-skala. 


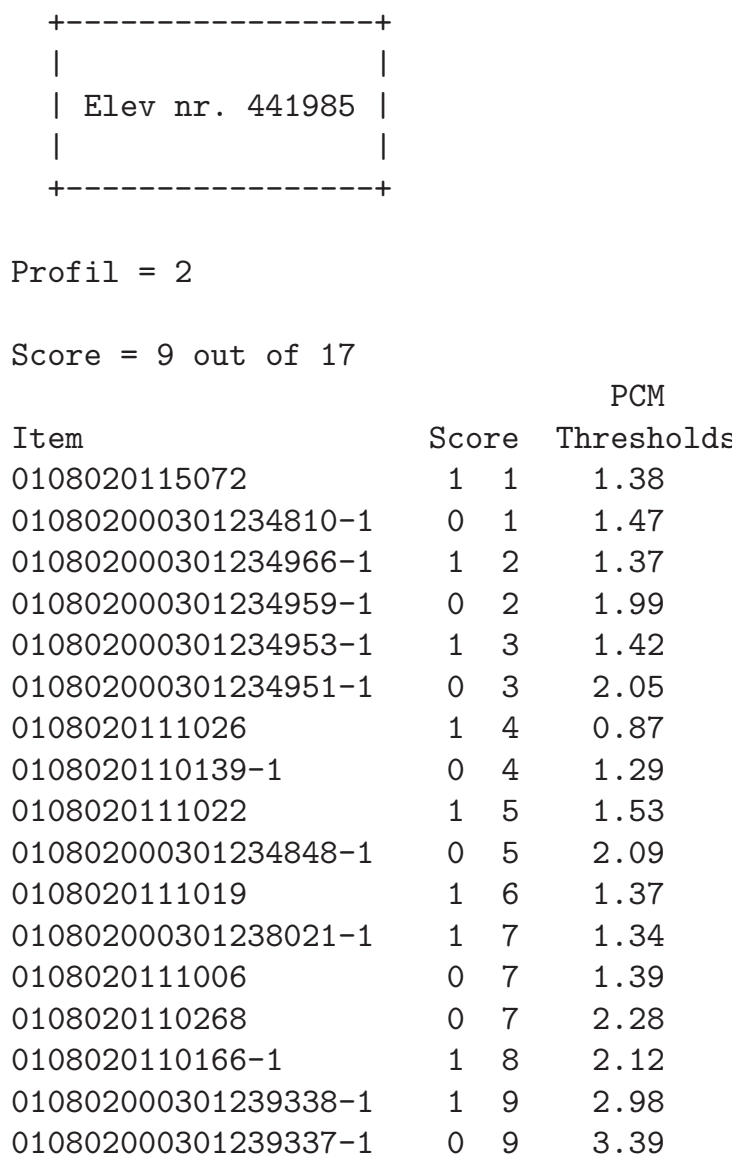

Derefter vises den betingede sandsynlighed for det observerede svarmønster givet en samlet score på 9 ud af 17 mulige point. Sandsynligheden er meget lille hvilket ikke er overraskende fordi man kan få 9 ud af 17 rigtige på 24.310 måder.

Den samlede sandsynlighed for alle svarmønstre med mindre eller samme sandsynlighed er lig med 0,254. Der er altså ikke tale om signifikant afvigelse fra Rasch-modellens forventninger.

$\operatorname{Prob}(1,0,1,0,1,0,1,0,1,0,1,1,0,0,1,1,0 \mid$ Score $=9)=0.00009287$

Monte Carlo test of person fit: $p=0.254$

Den næste tabel viser hvad der sker undervejs. Dygtigheden (WML) og usikkerheden beregnes fra og med tredje opgave og vises sammen med sværhedsgraden for næste opgave. Efter sjette trin er dygtigheden lig med 1,16, SEM = 0,83 og sværhedsgraden af næste opgave er lig med 0,87. DNT vælger altså en ny opgave som ifølge sværhedsgraderne fra 2017 er noget lettere end den burde være.

\begin{tabular}{|c|c|c|c|c|c|c|}
\hline \multirow[b]{2}{*}{ Item } & \multicolumn{3}{|c|}{ Conditional probabilites } & \multicolumn{2}{|c|}{ Person estimates } & \multirow[b]{2}{*}{ Next } \\
\hline & Item score & cumu. & ted score & WML & SEM & \\
\hline 10108020115072 & 10.62974 & 1 & 0.62974 & & & \\
\hline $2010802000301234810-1$ & 0.39136 & 1 & 0.50255 & & & \\
\hline $3010802000301234966-1$ & 0.63323 & 2 & 0.48135 & 1.92 & 1.05 & 1.99 \\
\hline $4010802000301234959-1$ & 0.52844 & 2 & 0.40503 & 1.55 & 0.99 & 1.42 \\
\hline $5010802000301234953-1$ & 0.62098 & 3 & 0.41637 & 1.87 & 0.91 & 2.05 \\
\hline $6010802000301234951-1$ & 0.54597 & 3 & 0.36464 & 1.61 & 0.83 & 0.87 \\
\hline 70108020111026 & 0.74592 & 4 & 0.38689 & 1.77 & 0.78 & 1.29 \\
\hline $80108020110139-1$ & 0.34737 & 4 & 0.28060 & 1.48 & 0.73 & 1.53 \\
\hline
\end{tabular}




$\begin{array}{rlrllllll}9 & 0108020111022 & 1 & 0.59302 & 5 & 0.35803 & 1.69 & 0.69 & 2.09 \\ 10 & 010802000301234848-1 & 0 & 0.55414 & 5 & 0.27526 & 1.55 & 0.65 & 1.37 \\ 11 & 0108020111019 & 1 & 0.63404 & 6 & 0.35918 & 1.70 & 0.62 & 1.34 \\ 12 & 010802000301238021-1 & 1 & 0.64127 & 7 & 0.42594 & 1.83 & 0.60 & 1.39 \\ 13 & 0108020111006 & 0 & 0.37053 & 7 & 0.29732 & 1.65 & 0.57 & 2.28 \\ 14 & 0108020110268 & 0 & 0.60364 & 7 & 0.15666 & 1.56 & 0.55 & 2.12 \\ 15 & 0108020110166-1 & 1 & 0.43655 & 8 & 0.33911 & 1.73 & 0.53 & 2.98 \\ 16 & 010802000301239338-1 & 1 & 0.23805 & 9 & 0.83135 & 1.93 & 0.52 & 3.39 \\ 17 & 010802000301239337-1 & 0 & 0.83135 & 9 & 1.00000 & 1.88 & 0.51 & \end{array}$

Nothing unexpected during the start or end of the test

Rank correlation between person estimate and next item $=0.59$

Estimates of person parameter

Optimal SEM with 17 dichotomous items 0.485

WML $=1.883 \quad$ SEM $=0.509 \quad$ Bias $=0.001$

ML $=1.892 \quad$ SEM $=0.539 \quad$ Bias $=0.001$

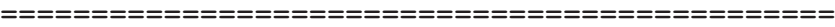

Korrelationen mellem WML-værdierne og næste sværhedsgrad er lig med 0,59.

Efter 17 opgaver vurderes dygtigheden på logit skalaen til at være 1,883 med en SEM på 0,509.

Bemærk, at vi både beregner WML-estimatet og det maksimum likelihood (ML) estimat som DNT benytter. Ifølge teorien burde der ikke være store forskelle i et adaptivt test. Det bekræftes af resultaterne.

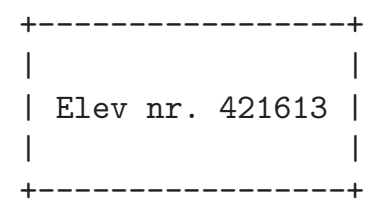

Profil $=3$

Score $=13$ out of 21

\begin{tabular}{lrcc} 
Item & \multicolumn{3}{c}{ PCM } \\
$01080306061340005-2$ & 0 & 0 & -0.47 \\
0108030311018 & 0 & 0 & 0.19 \\
$01080306061330044-3$ & 0 & 0 & 0.20 \\
$010803060613252-4$ & 0 & 0 & -0.26 \\
0108030320029 & 0 & 0 & -2.37 \\
$010803060613601-3$ & 0 & 0 & -2.33 \\
01080306061330109 & 0 & 0 & -1.59 \\
$0108030320022-3$ & 1 & 1 & -1.44 \\
0108030320040 & 1 & 2 & -0.91 \\
$01080306912-1 \_2$ & 1 & 3 & -0.78 \\
$0108030612006-1$ & 1 & 4 & -1.46 \\
0108030320033 & 1 & 5 & -1.54 \\
01080306061330104 & 1 & 6 & -1.22 \\
$0108030612019-1$ & 0 & 6 & -0.35
\end{tabular}




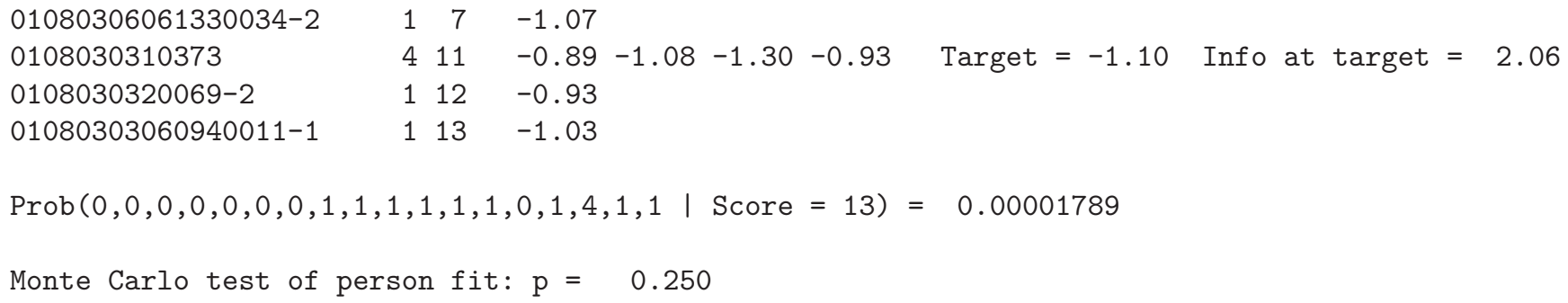

Den tredje sidste opgave er en polytom opgave med fire spørgsmål.

Target angiver den værdi af dygtigheden hvor denne opgave er mest informativ, og som DNT bruger til at vælge næste opgave.

Da en ud af 18 opgaver er polytom, kan denne elev score op til 21 point. Slutresultatet er imidlertid kun 13 point fordi der svares forkert på de første syv opgaver.

De mange forkerte svar i starten af forløbet ser mistænkelige ud, men selv om den betingede sandsynlighed for det observerede givet at der scores 13 ud af 21 mulige point, er meget lille, er det dog langt fra signifikant i sig selv. Set isoleret ud fra fokus på detaljerne er der intet der strider mod Rasch-modellens forventninger.

Det er der til gengæld hvis vi ser på sandsynligheden for at score nul point i de første opgaver. Nedenstående tabel viser således at sandsynligheden for at score nul point efter de første fem opgaver er nede på 0,013697. Dette tal er udtryk for signifikant forskel på starten af forløbet og Rasch-modellens forventninger, men det stopper ikke der.

Sandsynligheden for at score nul point på de første syv opgaver er endnu mindre, nemlig nede på 0,00010 altså endnu mere signifikant. Derefter begynder de korrekte svar at dukke op, men bemærk at det stadig er svagt signifikant, hvis der kun scores 4 point på de første 11 opgaver.

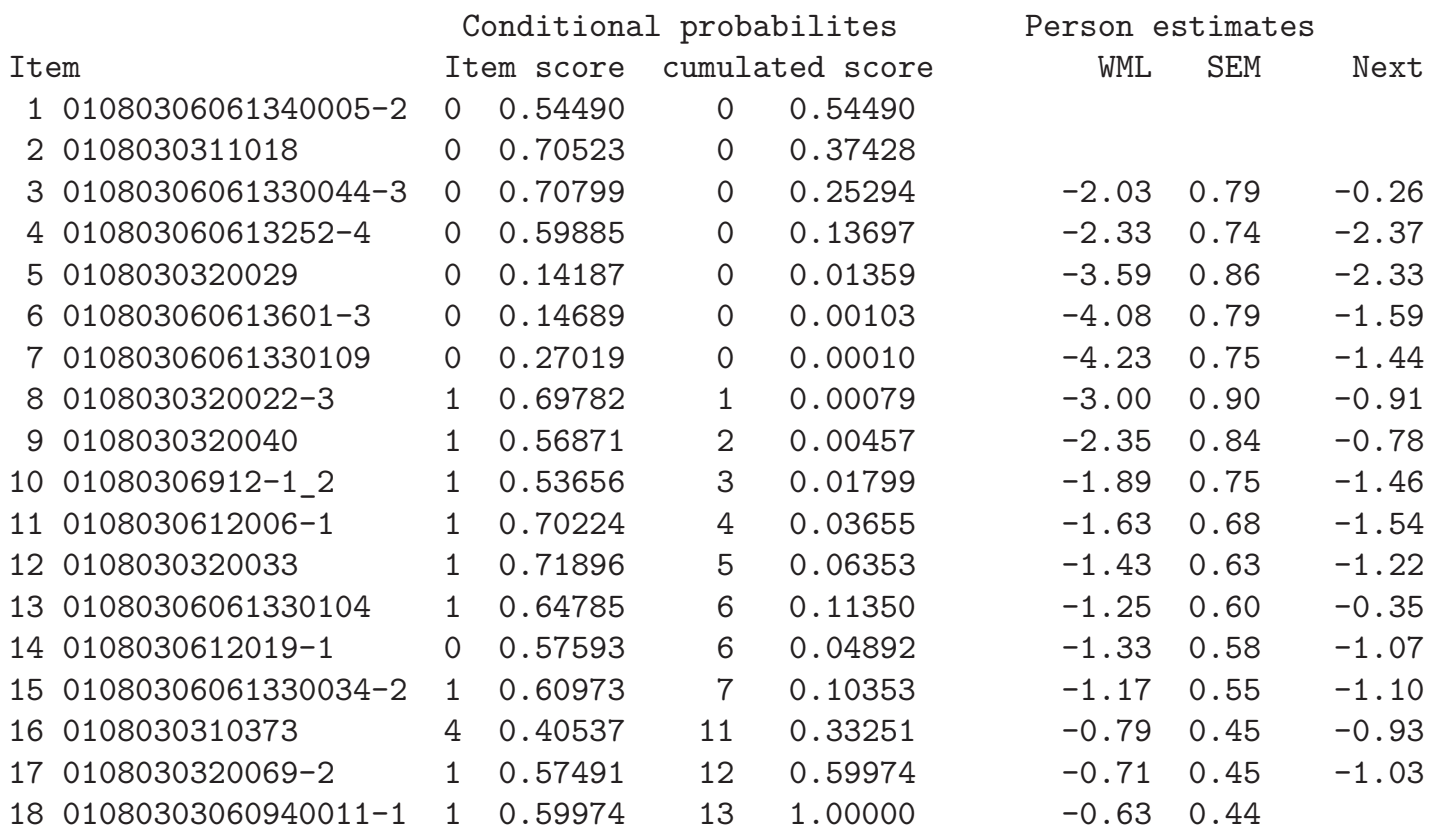

Responses to items 1 to 7 are significant. $p=0.0001$

Person parameter will be estimated based on the subscore of items $8-18$

Rank correlation between person estimate and next item $=0.64$ 


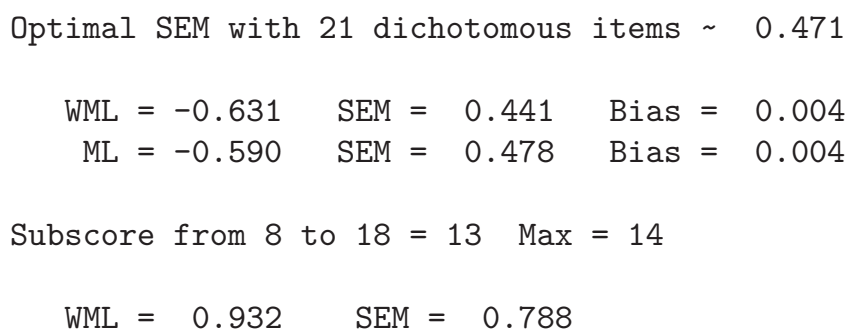

Ovenstående resultater forkaster Rasch-modellen for de første syv opgaver og fortæller derfor at det samlede bud på dygtigheden, der er lig med WML = -0,631, formodentlig undervurderer læsefærdigheden.

For at finde ud af hvor meget beregner programmet derfor dygtigheden hvis man kun bruger opgaverne 8 1il 18. Det giver et helt andet resultat, nemlig $\mathrm{WML}=0,932$.

I dette eksempel er konklusionen at man ved at ignorere det der sker i starten af forløbet, får et fuldstændig misvisende mål for hvor godt eleven læser. Det sidste bud er formodentlig tæettere på, men her er usikkerheden til gengæld så stor, at dette resultat heller ikke er anvendeligt. Dette er et eksempel på et helt mislykket testforløb med et resultat der burde ignoreres.

\section{B.3 Ukommenterede forløb}

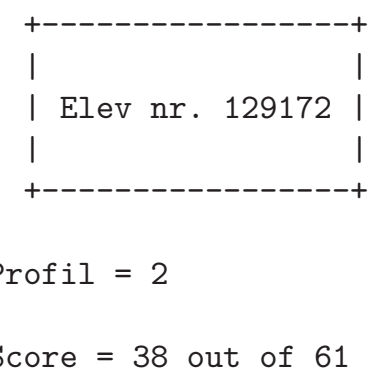

$\begin{array}{lrrc} & & & \text { PCM } \\ \text { Item } & \text { Score } & \text { Thresholds } \\ 0108020111018 & 0 & 0 & 1.05 \\ 010802000301234952-1 & 0 & 0 & 1.09 \\ 0108020111011 & 0 & 0 & -0.07 \\ 010802000301234955-1 & 0 & 0 & -0.99 \\ 0108020115060 & 0 & 0 & -0.74 \\ 010802000301237986-1 & 1 & 1 & -2.25 \\ 0108020110177-1 & 1 & 2 & -1.45 \\ 010802000301237983-1 & 1 & 3 & -2.63 \\ 0108020110172-1 & 1 & 4 & -1.38 \\ 0108020110228 & 1 & 5 & -0.09 \\ 0108020110111-1 & 1 & 6 & -1.31 \\ 0108020110052-1 & 1 & 7 & -0.84 \\ 0108020110007-1 & 1 & 8 & -0.89 \\ 0108020111012 & 1 & 9 & -0.25 \\ 0108020110053-1 & 1 & 10 & -0.84 \\ 010802000301234962-1 & 1 & 11 & -0.79 \\ 0108020110261 & 1 & 12 & -0.04\end{array}$




$\begin{array}{lllr}0108020110245 & 1 & 13 & -0.74 \\ 0108020110038-1 & 0 & 13 & -0.05 \\ 0108020110219-1 & 1 & 14 & 0.04 \\ 0108020110155-1 & 1 & 15 & -0.19 \\ 0108020110232 & 0 & 15 & -0.51 \\ 0108020115013 & 1 & 16 & 0.05 \\ 0108020110082-1 & 0 & 16 & 0.13 \\ 0108020110059-1 & 1 & 17 & 0.43 \\ 0108020110003-1 & 1 & 18 & -0.63 \\ 010802000301234881-1 & 1 & 19 & 0.27 \\ 0108020111034 & 1 & 20 & 0.03 \\ 0108020110217-1 & 0 & 20 & 0.21 \\ 010802000301239438-1 & 1 & 21 & 0.51 \\ 010802000301234811-1 & 0 & 21 & 0.50 \\ 0108020110024-1 & 0 & 21 & 0.53 \\ 0108020110105-1 & 1 & 22 & -0.96 \\ 0108020110162-1 & 0 & 22 & 1.15 \\ 0108020110234 & 0 & 22 & -0.34 \\ 0108020110205-1 & 1 & 23 & 0.05 \\ 0108020110079-1 & 1 & 24 & 0.22 \\ 0108020110018-1 & 1 & 25 & 0.02 \\ 0108020111031 & 0 & 25 & 0.06 \\ 0108020110156-1 & 0 & 25 & -0.12 \\ 0108020115028 & 0 & 25 & 0.22 \\ 0108020110085-1 & 1 & 26 & 0.05 \\ 010802000301234855-1 & 0 & 26 & 0.29 \\ 0108020110206-1 & 1 & 27 & 0.40 \\ 0108020110144-1 & 0 & 27 & 0.39 \\ 0108020110137-1 & 1 & 28 & 0.78 \\ 0108020110131-1 & 1 & 29 & 0.21 \\ 0108020110006-1 & 1 & 30 & -0.39 \\ 0108020110088-1 & 1 & 31 & 0.43 \\ 0108020110036-1 & 0 & 31 & 0.29 \\ 0108020111023 & 1 & 32 & 0.18 \\ 0108020111033 & 1 & 33 & 0.15 \\ 0108020110074-1 & 0 & 33 & 0.45 \\ 0108020115027 & 1 & 34 & 0.27 \\ 0108020110164-1 & 1 & 35 & -0.80 \\ 0108020110267 & 0 & 35 & 0.48 \\ 010802000301234956-1 & 0 & 35 & 0.41 \\ 010802000301234946-1 & 1 & 36 & 0.28 \\ 0108020111004 & 1 & 37 & -0.05 \\ 0108020110263 & 0 & 37 & 0.64 \\ 0108020110201-1 & 1 & 38 & 0.28\end{array}$

$\operatorname{Prob}(0,0,0,0,0,1,1,1,1,1,1,1,1,1,1,1,1,1,0,1,1,0,1,0,1,1,1,1,0,1,0,0,1,0,0,1,1,1$, $0,0,0,1,0,1,0,1,1,1,1,0,1,1,0,1,1,0,0,1,1,0,1 \mid$ Score $=38)=0.0000000000000020$

Monte Carlo test of person fit: $\mathrm{p}=0.725$

\begin{tabular}{|c|c|c|c|c|}
\hline & Conditiona & 1 probabilites & \multicolumn{2}{|c|}{ Person estimates } \\
\hline Item & Item score & cumulated score & WML & SEM \\
\hline 10108020111018 & $0 \quad 0.64713$ & $0 \quad 0.64713$ & & \\
\hline $2010802000301234952-1$ & 0.65448 & 0.41957 & & \\
\hline
\end{tabular}




\begin{tabular}{|c|c|c|c|c|c|c|c|c|}
\hline 3 & 0108020111011 & 0 & 0.36870 & 0 & 0.14931 & -1.43 & 0.82 & -0.99 \\
\hline 4 & $010802000301234955-1$ & 0 & 0.18624 & 0 & 0.02543 & -2.35 & 0.82 & -0.74 \\
\hline 5 & 0108020115060 & 0 & 0.22835 & 0 & 0.00505 & -2.70 & 0.76 & -2.25 \\
\hline 6 & 010802000301237986-1 & 1 & 0.93923 & 1 & 0.00813 & -2.07 & 1.01 & -1.45 \\
\hline 7 & 0108020110177-1 & 1 & 0.87451 & 2 & 0.01550 & -1.56 & 0.91 & -2.63 \\
\hline 8 & 010802000301237983-1 & 1 & 0.95771 & 3 & 0.01859 & -1.42 & 0.85 & -1.38 \\
\hline 9 & $0108020110172-1$ & 1 & 0.86558 & 4 & 0.02911 & -1.14 & 0.77 & -0.09 \\
\hline 10 & 0108020110228 & 1 & 0.63663 & 5 & 0.06347 & -0.76 & 0.73 & -1.31 \\
\hline 11 & 0108020110111-1 & 1 & 0.85787 & 6 & 0.08101 & -0.61 & 0.69 & -0.84 \\
\hline 12 & 0108020110052-1 & 1 & 0.78944 & 7 & 0.10811 & -0.43 & 0.66 & -0.89 \\
\hline 13 & 0108020110007-1 & 1 & 0.79815 & 8 & 0.13447 & -0.28 & 0.64 & -0.25 \\
\hline 14 & 0108020111012 & 1 & 0.67213 & 9 & 0.17575 & -0.10 & 0.62 & -0.84 \\
\hline 15 & 0108020110053-1 & 1 & 0.78910 & 10 & 0.19877 & 0.01 & 0.60 & -0.79 \\
\hline 16 & $010802000301234962-1$ & 1 & 0.78019 & 11 & 0.21886 & 0.11 & 0.59 & -0.04 \\
\hline 17 & 0108020110261 & 1 & 0.62394 & 12 & 0.24413 & 0.25 & 0.58 & -0.74 \\
\hline 18 & 0108020110245 & 1 & 0.77210 & 13 & 0.25096 & 0.33 & 0.57 & -0.05 \\
\hline 19 & 0108020110038-1 & 0 & 0.37393 & 13 & 0.20809 & 0.17 & 0.53 & 0.04 \\
\hline 20 & 0108020110219-1 & 1 & 0.60431 & 14 & 0.23055 & 0.29 & 0.53 & -0.19 \\
\hline 21 & 0108020110155-1 & 1 & 0.65970 & 15 & 0.23872 & 0.39 & 0.52 & -0.51 \\
\hline 22 & 0108020110232 & 0 & 0.27070 & 15 & 0.20184 & 0.22 & 0.49 & 0.05 \\
\hline 23 & 0108020115013 & 1 & 0.60399 & 16 & 0.22133 & 0.32 & 0.48 & 0.13 \\
\hline 24 & 0108020110082-1 & 0 & 0.41693 & 16 & 0.18609 & 0.21 & 0.46 & 0.43 \\
\hline 25 & 0108020110059-1 & 1 & 0.50685 & 17 & 0.21282 & 0.32 & 0.46 & -0.63 \\
\hline 26 & $0108020110003-1$ & 1 & 0.75143 & 18 & 0.22000 & 0.37 & 0.45 & 0.27 \\
\hline 27 & $010802000301234881-1$ & 1 & 0.54831 & 19 & 0.22312 & 0.46 & 0.45 & 0.03 \\
\hline 28 & 0108020111034 & 1 & 0.60689 & 20 & 0.21437 & 0.54 & 0.44 & 0.21 \\
\hline 29 & 0108020110217-1 & 0 & 0.43795 & 20 & 0.21971 & 0.44 & 0.42 & 0.51 \\
\hline 30 & 010802000301239438-1 & 1 & 0.48668 & 21 & 0.21302 & 0.52 & 0.42 & 0.50 \\
\hline 31 & $010802000301234811-1$ & 0 & 0.51045 & 21 & 0.21793 & 0.44 & 0.41 & 0.53 \\
\hline 32 & 0108020110024-1 & 0 & 0.51833 & 21 & 0.20862 & 0.37 & 0.39 & -0.96 \\
\hline 33 & 0108020110105-1 & 1 & 0.80835 & 22 & 0.21366 & 0.40 & 0.39 & 1.15 \\
\hline 34 & $0108020110162-1$ & 0 & 0.66945 & 22 & 0.20368 & 0.36 & 0.38 & -0.34 \\
\hline 35 & 0108020110234 & 0 & 0.30660 & 22 & 0.16593 & 0.27 & 0.37 & 0.05 \\
\hline 36 & 0108020110205-1 & 1 & 0.60320 & 23 & 0.19041 & 0.32 & 0.37 & 0.22 \\
\hline 37 & 0108020110079-1 & 1 & 0.56156 & 24 & 0.21034 & 0.39 & 0.37 & 0.02 \\
\hline 38 & 0108020110018-1 & 1 & 0.60967 & 25 & 0.21939 & 0.44 & 0.36 & 0.06 \\
\hline 39 & 0108020111031 & 0 & 0.39925 & 25 & 0.20446 & 0.37 & 0.35 & -0.12 \\
\hline 40 & 0108020110156-1 & 0 & 0.35700 & 25 & 0.16729 & 0.29 & 0.35 & 0.22 \\
\hline 41 & 0108020115028 & 0 & 0.43870 & 25 & 0.12560 & 0.23 & 0.34 & 0.05 \\
\hline 42 & 0108020110085-1 & 1 & 0.60343 & 26 & 0.15654 & 0.28 & 0.34 & 0.29 \\
\hline 43 & 010802000301234855-1 & 0 & 0.45685 & 26 & 0.11366 & 0.23 & 0.33 & 0.40 \\
\hline 44 & 0108020110206-1 & 1 & 0.51512 & 27 & 0.15325 & 0.29 & 0.33 & 0.39 \\
\hline 45 & 0108020110144-1 & 0 & 0.48265 & 27 & 0.10967 & 0.24 & 0.32 & 0.78 \\
\hline 46 & 0108020110137-1 & 1 & 0.42017 & 28 & 0.16037 & 0.30 & 0.32 & 0.21 \\
\hline 47 & 0108020110131-1 & 1 & 0.56261 & 29 & 0.20002 & 0.35 & 0.32 & -0.39 \\
\hline 48 & 0108020110006-1 & 1 & 0.70416 & 30 & 0.22519 & 0.38 & 0.31 & 0.43 \\
\hline 49 & 0108020110088-1 & 1 & 0.50788 & 31 & 0.25629 & 0.43 & 0.31 & 0.29 \\
\hline 50 & 0108020110036-1 & 0 & 0.45721 & 31 & 0.23198 & 0.38 & 0.31 & 0.18 \\
\hline 51 & 0108020111023 & 1 & 0.56961 & 32 & 0.26886 & 0.42 & 0.30 & 0.15 \\
\hline 52 & 0108020111033 & 1 & 0.57923 & 33 & 0.28947 & 0.46 & 0.30 & 0.45 \\
\hline 53 & $0108020110074-1$ & 0 & 0.49809 & 33 & 0.28662 & 0.42 & 0.30 & 0.27 \\
\hline 54 & 0108020115027 & 1 & 0.54703 & 34 & 0.32097 & 0.46 & 0.29 & -0.80 \\
\hline 55 & 0108020110164-1 & 1 & 0.78296 & 35 & 0.32989 & 0.47 & 0.29 & 0.48 \\
\hline 56 & 0108020110267 & 0 & 0.50438 & 35 & 0.34893 & 0.43 & 0.29 & 0.41 \\
\hline
\end{tabular}




$\begin{array}{llllllllr}57 & 010802000301234956-1 & 0 & 0.48788 & 35 & 0.29554 & 0.39 & 0.28 & 0.28 \\ 58 & 010802000301234946-1 & 1 & 0.54494 & 36 & 0.41722 & 0.43 & 0.28 & -0.05 \\ 59 & 0108020111004 & 1 & 0.62624 & 37 & 0.51381 & 0.46 & 0.28 & 0.64 \\ 60 & 0108020110263 & 0 & 0.54602 & 37 & 0.54636 & 0.43 & 0.28 & 0.28 \\ 61 & 0108020110201-1 & 1 & 0.54636 & 38 & 1.00000 & 0.46 & 0.28 & \end{array}$

Responses to items 1 to 5 are significant. $p=0.0050$

Person parameter will be estimated based on the subscore of items $6-61$

Rank correlation between person estimate and next item $=0.73$

Estimates of person parameter

Optimal SEM with 61 dichotomous items 0.256

WML $=0.460 \quad$ SEM $=0.276 \quad$ Bias $=0.000$

ML $=0.467 \quad$ SEM $=0.281 \quad$ Bias $=0.000$

Subscore from 6 to $61=38$ Max $=56$

WML $=0.701 \quad$ SEM $=0.296$

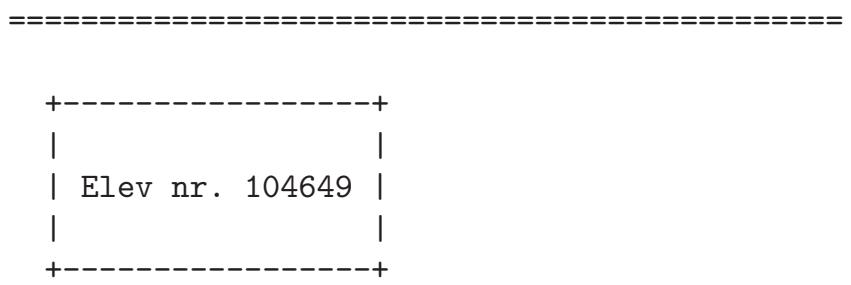

Profil $=3$

Score $=15$ out of 25

Item
$010803000301238303-1$
$010803000301238855-1$
01080306061340014
$010803060613252-4$
0108030320029
$010803060613601-3$
01080306061330109
0108030320040
$0108030320022-3$
$01080306912-1-2$
01080306061330104
$0108030610700-3$
0108030311017
$0108030610705-1$
$0108030320069-1$
0108030320045
0108030610352

Score Thresholds

$\begin{array}{lll}0 & 0 & -0.21\end{array}$

$\begin{array}{lll}0 & 0 & 0.84\end{array}$

$\begin{array}{lll}0 & 0 & -0.18\end{array}$

$\begin{array}{lll}0 & 0 & -0.26\end{array}$

$\begin{array}{lll}0 & 0 & -2.37\end{array}$

$1 \quad 1-2.33$

$12-1.59$

$13-0.91$

$14-1.44$

$15-0.78$

$\begin{array}{lll}1 & 6 & -1.22\end{array}$

$\begin{array}{llllll}3 & 9 & -1.29 & -1.19 & 0.52 & 2.58\end{array}$ Target $=-0.96$ Info at target $=0.86$

$\begin{array}{lll}0 & 9 & -0.15\end{array}$

$\begin{array}{lll}0 & 9 & -1.41\end{array}$

$110-0.39$

$111-0.81$

$112-0.54$ 


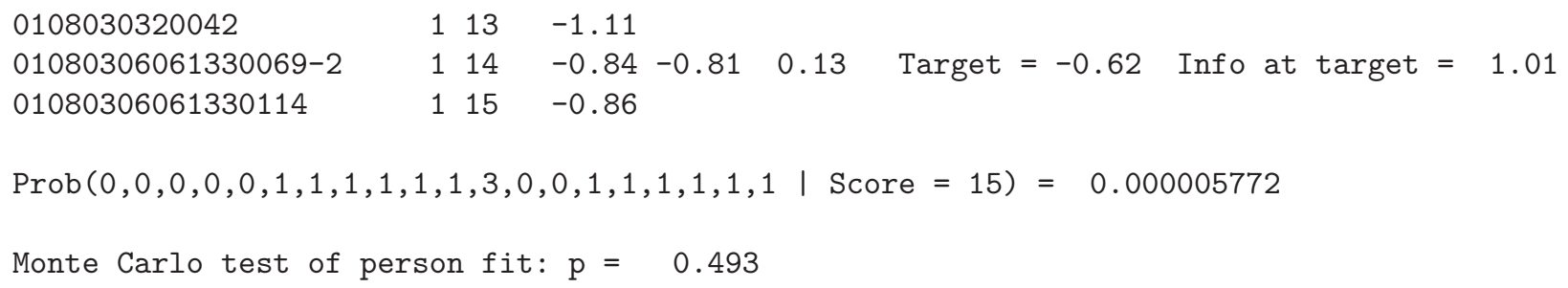

\begin{tabular}{|c|c|c|c|c|c|c|}
\hline \multirow[b]{2}{*}{ Item } & \multicolumn{3}{|c|}{ Conditional probabilites } & \multicolumn{3}{|c|}{ Person estimates } \\
\hline & Item score & cumu. & ted score & WML & SEM & Next \\
\hline $1010803000301238303-1$ & $0 \quad 0.52451$ & 0 & 0.52451 & & & \\
\hline $2010803000301238855-1$ & 0.76627 & 0 & 0.39362 & & & \\
\hline 301080306061340014 & 0.53113 & 0 & 0.19521 & -1.91 & 0.80 & -0.26 \\
\hline $4010803060613252-4$ & 0.50974 & 0 & 0.08720 & -2.25 & 0.75 & -2.37 \\
\hline 50108030320029 & 0.10480 & 0 & 0.00631 & -3.57 & 0.87 & -2.33 \\
\hline $6010803060613601-3$ & 0.89136 & 1 & 0.01451 & -2.57 & 1.02 & -1.59 \\
\hline 701080306061330109 & 0.79353 & 2 & 0.03388 & -1.95 & 0.92 & -0.91 \\
\hline 80108030320040 & 0.65385 & 3 & 0.07812 & -1.46 & 0.82 & -1.44 \\
\hline $90108030320022-3$ & 0.76695 & 4 & 0.11633 & -1.20 & 0.75 & -0.78 \\
\hline $1001080306912-1 \_2$ & 0.62406 & 5 & 0.18430 & -0.92 & 0.70 & -1.22 \\
\hline 1101080306061330104 & 0.72435 & 6 & 0.23328 & -0.75 & 0.66 & -0.96 \\
\hline $120108030610700-3$ & 0.20789 & 9 & 0.33014 & -0.29 & 0.59 & -0.15 \\
\hline 130108030311017 & 0.53938 & 9 & 0.31867 & -0.43 & 0.56 & -1.41 \\
\hline $140108030610705-1$ & 0.23890 & 9 & 0.21796 & -0.63 & 0.53 & -0.39 \\
\hline $150108030320069-1$ & 0.52435 & 10 & 0.30022 & -0.49 & 0.52 & -0.81 \\
\hline 160108030320045 & 0.62983 & 11 & 0.34537 & -0.38 & 0.51 & -0.54 \\
\hline 170108030610352 & 0.56224 & 12 & 0.34979 & -0.27 & 0.50 & -1.11 \\
\hline 180108030320042 & 0.70017 & 13 & 0.31855 & -0.21 & 0.49 & -0.62 \\
\hline $1901080306061330069-2$ & 0.23888 & 14 & 0.64259 & -0.36 & 0.44 & -0.86 \\
\hline $20 \quad 01080306061330114$ & 0.64259 & 15 & 1.00000 & -0.30 & 0.43 & \\
\hline
\end{tabular}

Responses to items 1 to 5 are significant. $p=0.0063$

Person parameter will be estimated based on the subscore of items $6-20$

Rank correlation between person estimate and next item $=0.69$

Estimates of person parameter

Optimal SEM with 25 dichotomous items 0.447

WML $=-0.297 \quad$ SEM $=0.430 \quad$ Bias $=0.001$

ML $=-0.275 \quad$ SEM $=0.451 \quad$ Bias $=0.001$

Subscore from 6 to $20=15$ Max $=20$

WML $=0.318 \quad$ SEM $=0.557$

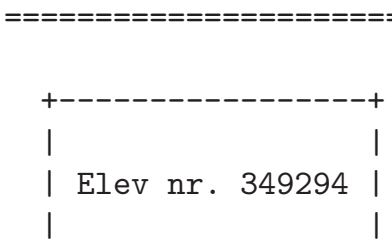




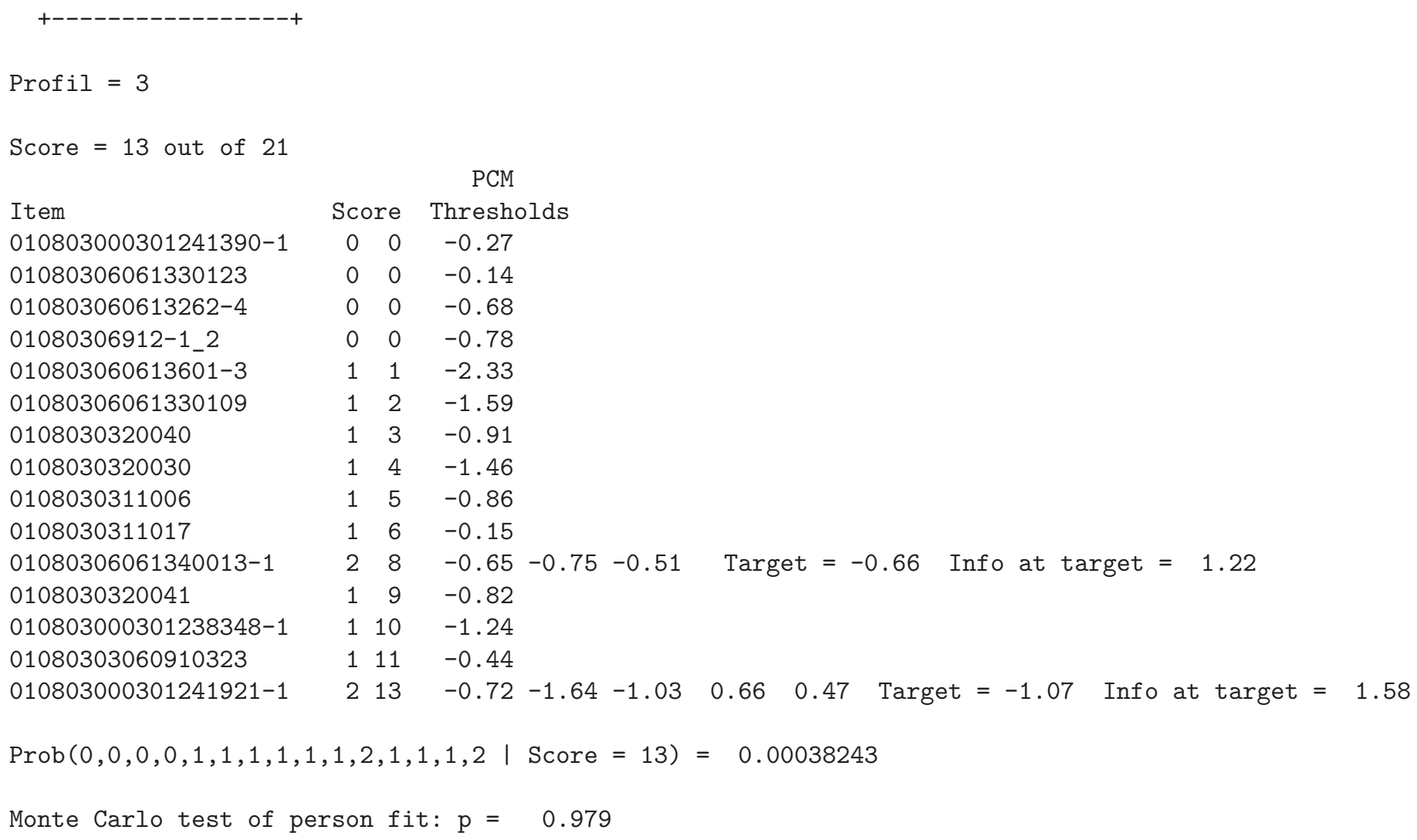


B.3 Ukommenterede forløb

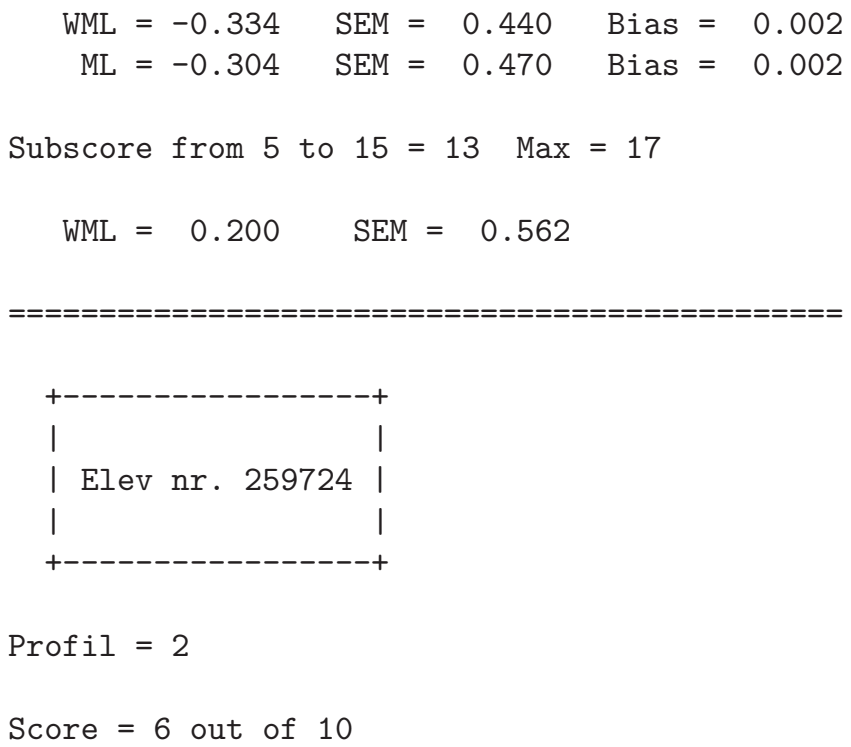

\begin{tabular}{|c|c|c|c|}
\hline Item & \multicolumn{2}{|c|}{ Score } & Thresholds \\
\hline 0108020115072 & 0 & 0 & 1.38 \\
\hline 0108020110081-1 & 0 & 0 & 0.40 \\
\hline 0108020111011 & 0 & 0 & -0.07 \\
\hline 0108020110086-1 & 0 & 0 & -0.65 \\
\hline $0108020110172-1$ & 1 & 1 & -1.38 \\
\hline 0108020115042 & 1 & 2 & -1.04 \\
\hline $0108020110147-1$ & 1 & 3 & -0.18 \\
\hline 0108020111012 & 1 & 4 & -0.25 \\
\hline 0108020110190-1 & 1 & 5 & -0.92 \\
\hline $0108020110084-1$ & 1 & 6 & -0.45 \\
\hline
\end{tabular}

$\operatorname{Prob}(0,0,0,0,1,1,1,1,1,1 \mid$ Score $=6)=0.02372005$

Monte Carlo test of person fit: $p=0.957$

\begin{tabular}{|c|c|c|c|c|c|c|c|c|}
\hline \multirow{2}{*}{\multicolumn{2}{|c|}{ Item }} & \multicolumn{4}{|c|}{ Conditional probabilites } & \multicolumn{3}{|c|}{ Person estimates } \\
\hline & & \multicolumn{2}{|c|}{ Item score } & \multicolumn{2}{|c|}{ cumulated score } & \multirow[t]{2}{*}{ WML } & \multirow[t]{2}{*}{ SEM } & \multirow[t]{2}{*}{ Next } \\
\hline 1 & 0108020115072 & 0 & 0.81003 & 0 & 0.81003 & & & \\
\hline 2 & 0108020110081-1 & 0 & 0.59122 & 0 & 0.46119 & & & \\
\hline 3 & 0108020111011 & 0 & 0.45998 & 0 & 0.17119 & -1.56 & 0.81 & -0.65 \\
\hline 4 & 0108020110086-1 & 0 & 0.30730 & 0 & 0.02372 & -2.20 & 0.78 & -1.38 \\
\hline 5 & 0108020110172-1 & 1 & 0.83285 & 1 & 0.04711 & -1.43 & 1.00 & -1.04 \\
\hline 6 & 0108020115042 & 1 & 0.77712 & 2 & 0.09019 & -0.98 & 0.92 & -0.18 \\
\hline 7 & $0108020110147-1$ & 1 & 0.57095 & 3 & 0.23137 & -0.55 & 0.83 & -0.25 \\
\hline 8 & 0108020111012 & 1 & 0.58946 & 4 & 0.46329 & -0.25 & 0.76 & -0.92 \\
\hline 9 & 0108020110190-1 & 1 & 0.75370 & 5 & 0.64445 & -0.10 & 0.72 & -0.45 \\
\hline 10 & 0108020110084-1 & 1 & 0.64445 & 6 & 1.00000 & 0.08 & 0.69 & \\
\hline
\end{tabular}

Nothing unexpected during the start or end of the test

Rank correlation between person estimate and next item $=0.67$

Estimates of person parameter 


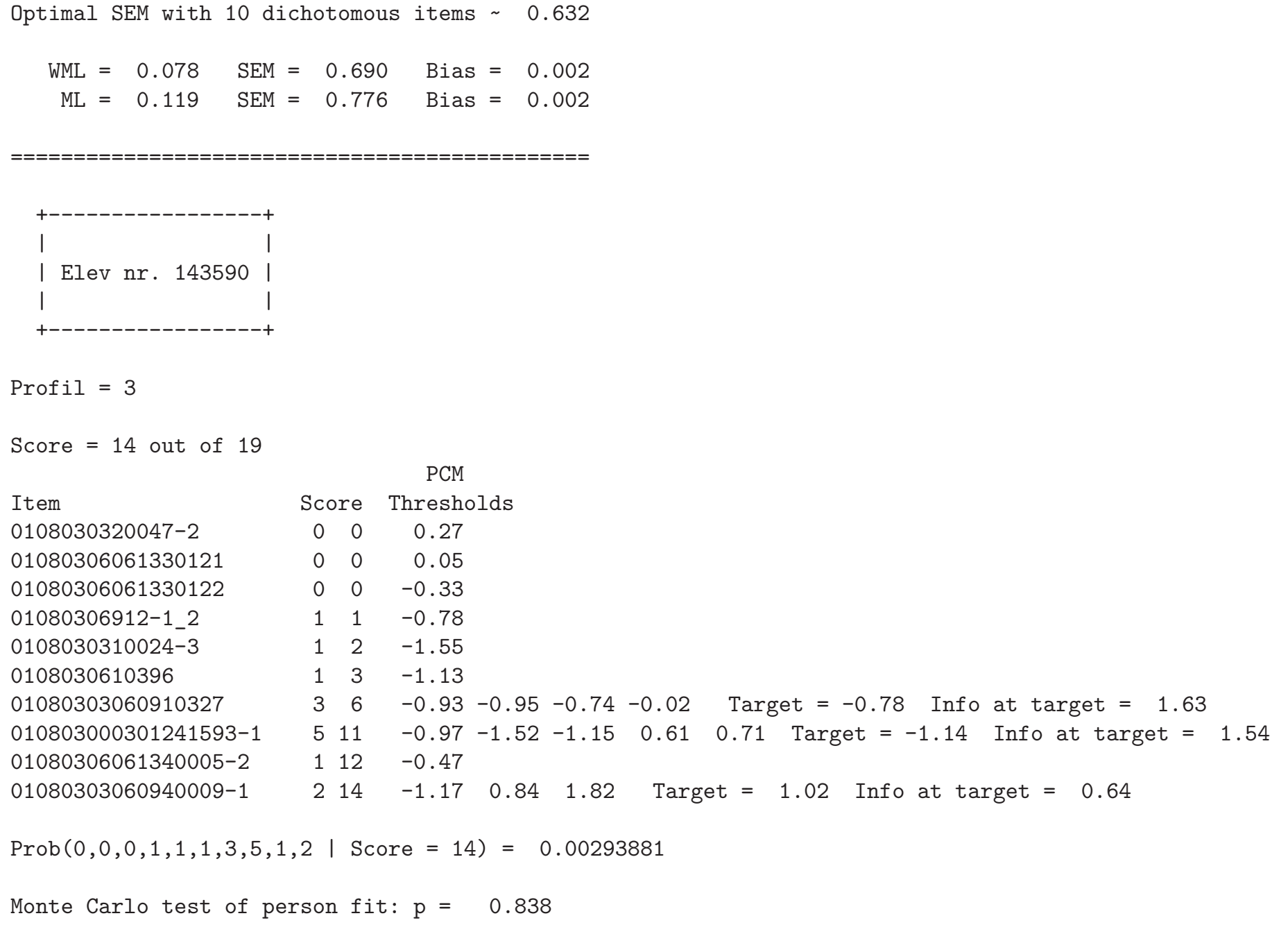

\begin{tabular}{|c|c|c|c|c|c|c|c|}
\hline \multirow{2}{*}{\multicolumn{2}{|c|}{ Item }} & \multicolumn{3}{|c|}{ Conditional probabilites } & \multicolumn{3}{|c|}{ Person estimates } \\
\hline & & Item score & cumul & ted score & WML & SEM & Next \\
\hline 1 & $0108030320047-2$ & $0 \quad 0.42541$ & 0 & 0.42541 & & & \\
\hline 2 & 01080306061330121 & 0.36953 & 0 & 0.13790 & & & \\
\hline 3 & 01080306061330122 & 0.27983 & 0 & 0.02679 & -1.98 & 0.78 & -0.78 \\
\hline 4 & 01080306912-1_2 & 0.80605 & 1 & 0.05918 & -1.09 & 0.98 & -1.55 \\
\hline 5 & $0108030310024-3$ & 0.90187 & 2 & 0.07915 & -0.83 & 0.95 & -1.13 \\
\hline 6 & 0108030610396 & 0.85607 & 3 & 0.11132 & -0.57 & 0.86 & -0.78 \\
\hline 7 & 01080303060910327 & 0.33444 & 6 & 0.04683 & -0.36 & 0.62 & -1.14 \\
\hline 8 & $010803000301241593-1$ & 0.23718 & 11 & 0.28431 & 0.24 & 0.59 & -0.47 \\
\hline 9 & $01080306061340005-2$ & 0.74967 & 12 & 0.36339 & 0.34 & 0.58 & 1.02 \\
\hline 10 & 01080303060940009-1 & 0.36339 & 14 & 1.00000 & 0.54 & 0.55 & \\
\hline
\end{tabular}

Responses to items 1 to 3 are significant. $p=0.0268$

Person parameter will be estimated based on the subscore of items $4-10$

Rank correlation between person estimate and next item $=0.67$

Estimates of person parameter 

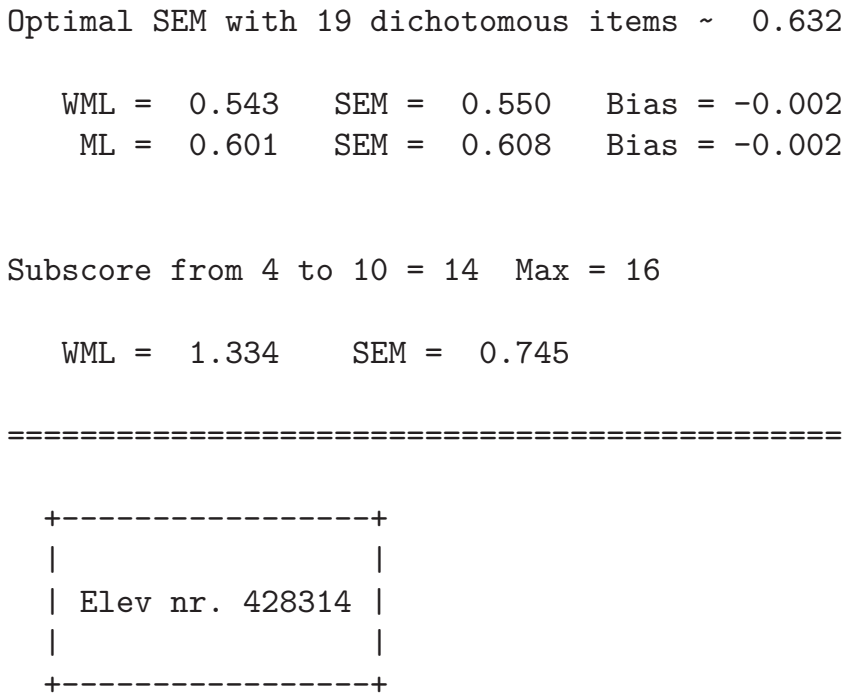

Profil $=3$

Score $=18$ out of 25

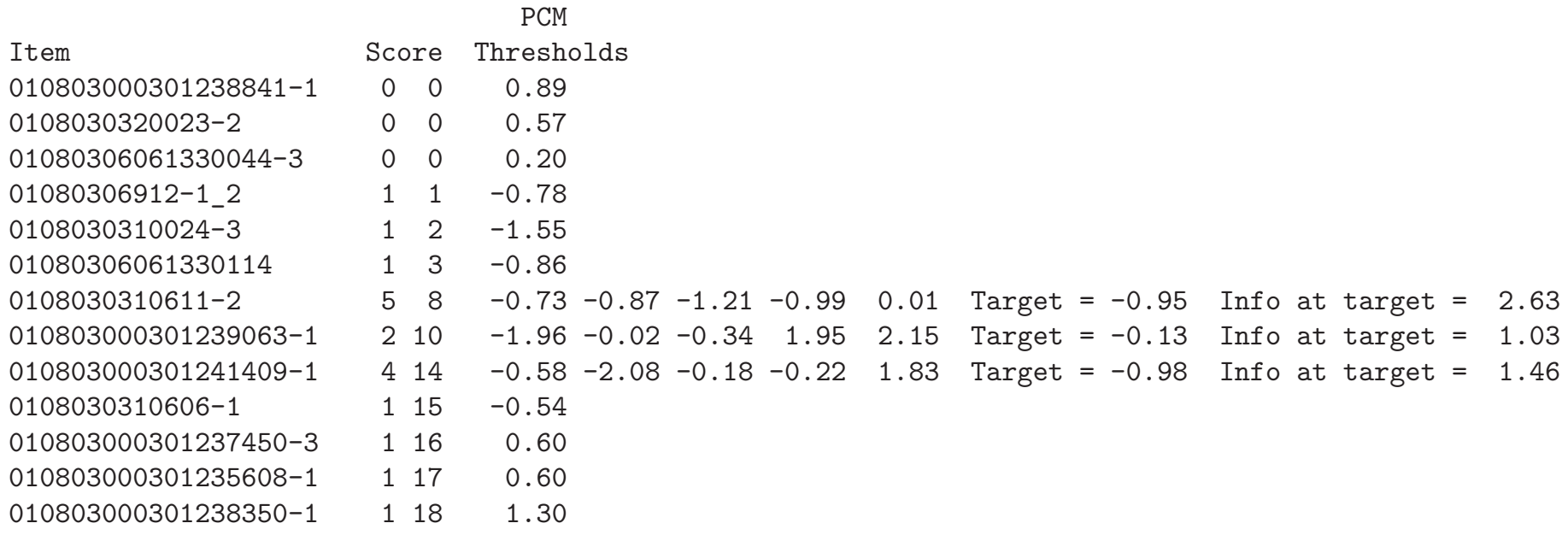

$\operatorname{Prob}(0,0,0,1,1,1,5,2,4,1,1,1,1 \mid$ Score $=18)=0.00140119$

Monte Carlo test of person fit: $p=0.963$

\begin{tabular}{|c|c|c|c|c|c|c|c|}
\hline \multirow{2}{*}{\multicolumn{2}{|c|}{ Item }} & \multicolumn{3}{|c|}{ Conditional probabilites } & \multicolumn{3}{|c|}{ Person estimates } \\
\hline & & Item score & cumul & ted score & WML & SEM & Next \\
\hline 1 & $010803000301238841-1$ & $0 \quad 0.52839$ & 0 & 0.52839 & & & \\
\hline 2 & 0108030320023-2 & 0.44298 & 0 & 0.21595 & & & \\
\hline 3 & $01080306061330044-3$ & 0.34925 & 0 & 0.05896 & -1.44 & 0.78 & -0.78 \\
\hline 4 & 01080306912-1_2 & 0.84025 & 1 & 0.09778 & -0.73 & 1.02 & -1.55 \\
\hline 5 & $0108030310024-3$ & 0.92031 & 2 & 0.11822 & -0.53 & 0.98 & -0.86 \\
\hline 6 & 01080306061330114 & 0.85059 & 3 & 0.15776 & -0.25 & 0.89 & -0.95 \\
\hline 7 & 0108030310611-2 & 0.66541 & 8 & 0.25591 & 0.15 & 0.70 & -0.13 \\
\hline 8 & $010803000301239063-1$ & 0.17107 & 10 & 0.06713 & 0.07 & 0.56 & -0.98 \\
\hline 9 & 010803000301241409-1 & 0.58918 & 14 & 0.06182 & 0.27 & 0.51 & -0.54 \\
\hline 10 & 0108030310606-1 & 0.80319 & 15 & 0.08604 & 0.34 & 0.51 & 0.60 \\
\hline
\end{tabular}




$\begin{array}{lllllllll}11 & 010803000301237450-3 & 1 & 0.54894 & 16 & 0.18388 & 0.49 & 0.51 & 0.60 \\ 12 & 010803000301235608-1 & 1 & 0.55021 & 17 & 0.36424 & 0.62 & 0.51 & 1.30 \\ 13 & 010803000301238350-1 & 1 & 0.36424 & 18 & 1.00000 & 0.79 & 0.51 & \end{array}$

Nothing unexpected during the start or end of the test

Rank correlation between person estimate and next item $=0.86$

Estimates of person parameter

Optimal SEM with 25 dichotomous items 0.555

WML $=0.787 \quad$ SEM $=0.506 \quad$ Bias $=-0.001$

ML $=0.833 \quad$ SEM $=0.524 \quad$ Bias $=-0.001$

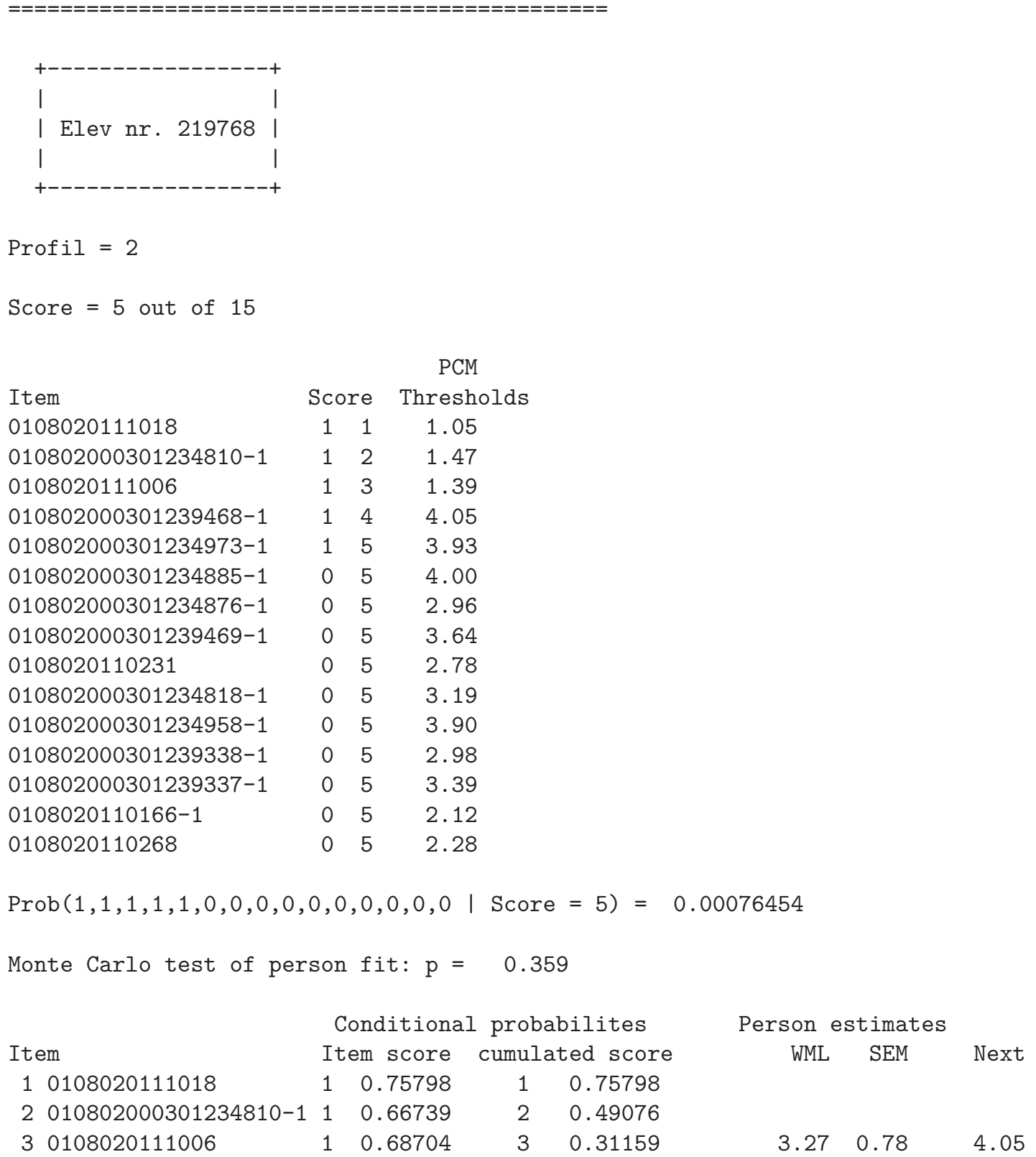




$\begin{array}{rllllllll}4 & 010802000301239468-1 & 1 & 0.10976 & 4 & 0.02128 & 5.16 & 0.99 & 3.93 \\ 5 & 010802000301234973-1 & 1 & 0.12237 & 5 & 0.00076 & 5.65 & 0.83 & 4.00 \\ 6 & 010802000301234885-1 & 0 & 0.88546 & 5 & 0.00243 & 4.58 & 1.00 & 2.96 \\ 7 & 010802000301234876-1 & 0 & 0.72038 & 5 & 0.01016 & 3.87 & 0.93 & 3.64 \\ 8 & 010802000301239469-1 & 0 & 0.84127 & 5 & 0.01911 & 3.53 & 0.83 & 2.78 \\ 9 & 0108020110231 & 0 & 0.67741 & 5 & 0.04900 & 3.14 & 0.76 & 3.19 \\ 10 & 010802000301234818-1 & 0 & 0.76640 & 5 & 0.08473 & 2.91 & 0.72 & 3.90 \\ 11 & 010802000301234958-1 & 0 & 0.87391 & 5 & 0.10948 & 2.80 & 0.69 & 2.98 \\ 12 & 010802000301239338-1 & 0 & 0.72368 & 5 & 0.18226 & 2.61 & 0.66 & 3.39 \\ 13 & 010802000301239337-1 & 0 & 0.80339 & 5 & 0.24981 & 2.49 & 0.64 & 2.12 \\ 14 & 0108020110166-1 & 0 & 0.50493 & 5 & 0.54772 & 2.27 & 0.62 & 2.28 \\ 15 & 0108020110268 & 0 & 0.54772 & 5 & 1.00000 & 2.10 & 0.61 & \end{array}$

Responses to items 1 to 5 are significant. $p=0.0008$

Person parameter will be estimated based on the subscore of items $6-15$

Rank correlation between person estimate and next item $=0.71$

Estimates of person parameter

Optimal SEM with 15 dichotomous items 0.516

WML $=2.099 \quad$ SEM $=0.608 \quad$ Bias $=-0.000$

$\mathrm{ML}=2.056 \quad \mathrm{SEM}=0.658 \quad$ Bias $=-0.000$

Subscore from 6 to $15=0 \quad \operatorname{Max}=10$

WML $=-0.114 \quad$ SEM $=0.684$

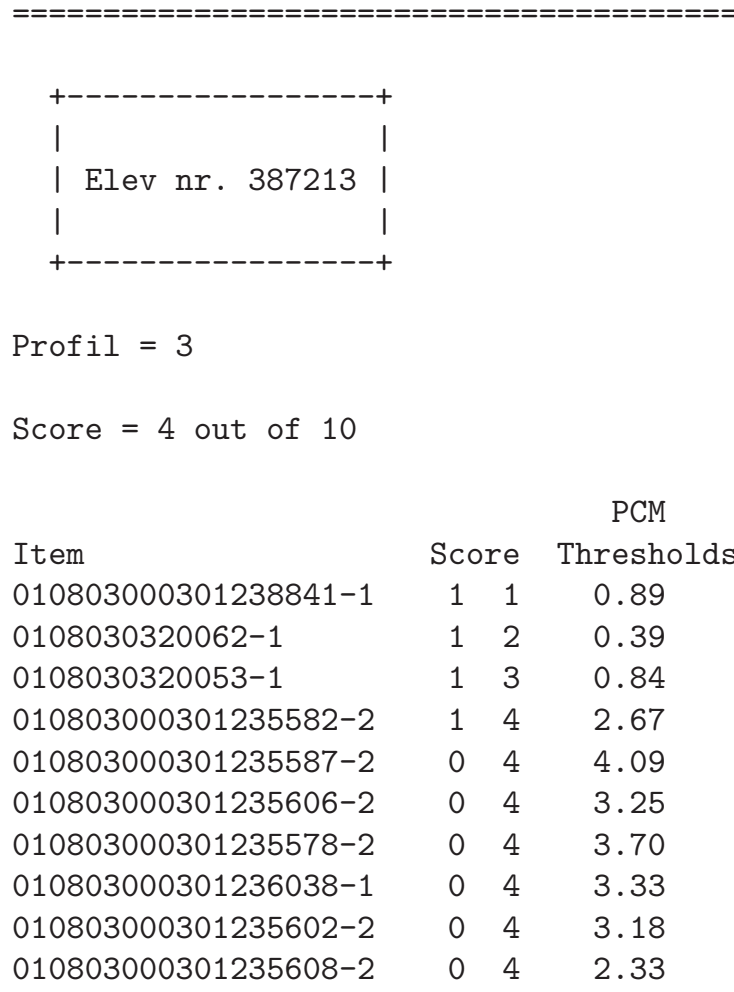




\begin{tabular}{|c|c|c|c|c|c|c|c|c|}
\hline \multicolumn{9}{|c|}{ Monte Carlo test of person } \\
\hline \multicolumn{6}{|c|}{ Conditional probabilites } & \multicolumn{3}{|c|}{ Person estimates } \\
\hline It & & & em score & cumul & ted score & WML & SEM & Next \\
\hline 1 & 010803000301238841-1 & 1 & 0.78942 & 1 & 0.78942 & & & \\
\hline 2 & 0108030320062-1 & 1 & 0.86542 & 2 & 0.67333 & & & \\
\hline 3 & 0108030320053-1 & 1 & 0.79836 & 3 & 0.51600 & 2.68 & 0.78 & 2.67 \\
\hline 4 & $010803000301235582-2$ & 1 & 0.32219 & 4 & 0.11074 & 3.89 & 0.85 & 4.09 \\
\hline 5 & $010803000301235587-2$ & 0 & 0.90942 & 4 & 0.14884 & 3.48 & 1.16 & 3.25 \\
\hline 6 & $010803000301235606-2$ & 0 & 0.80380 & 4 & 0.24424 & 2.95 & 1.02 & 3.70 \\
\hline 7 & $010803000301235578-2$ & 0 & 0.86919 & 4 & 0.31638 & 2.72 & 0.92 & 3.33 \\
\hline 8 & 010803000301236038-1 & 0 & 0.81696 & 4 & 0.43171 & 2.50 & 0.85 & 3.18 \\
\hline 9 & $010803000301235602-2$ & 0 & 0.79120 & 4 & 0.58481 & 2.30 & 0.80 & 2.33 \\
\hline 10 & 010803000301235608-2 & 0 & 0.58481 & 4 & 1.00000 & 2.03 & 0.76 & \\
\hline
\end{tabular}

Nothing unexpected during the start or end of the test

Rank correlation between person estimate and next item $=0.86$

Estimates of person parameter

Optimal SEM with 10 dichotomous items 0.632

WML $=2.026 \quad$ SEM $=0.759 \quad$ Bias $=-0.002$

ML $=1.979 \quad$ SEM $=0.815 \quad$ Bias $=-0.002$

\begin{tabular}{|c|c|c|c|}
\hline \multicolumn{4}{|l|}{ +---------------- +} \\
\hline \multicolumn{4}{|l|}{ 1 1 } \\
\hline \multicolumn{4}{|l|}{ | Elev nr. 439773 | } \\
\hline \multicolumn{4}{|l|}{ 1 1} \\
\hline \multicolumn{4}{|l|}{+-----------------+} \\
\hline \multicolumn{4}{|l|}{ Profil $=2$} \\
\hline \multicolumn{4}{|l|}{ Score $=9$ out of 23} \\
\hline & & & PCM \\
\hline Item & $\mathrm{Sc}$ & & Thresholds \\
\hline 0108020111016 & 1 & 1 & 0.46 \\
\hline 0108020111022 & 1 & 2 & 1.53 \\
\hline 0108020111006 & 1 & 3 & 1.39 \\
\hline 010802000301239468-1 & 1 & 4 & 4.05 \\
\hline 010802000301234973-1 & 0 & 4 & 3.93 \\
\hline 010802000301234876-1 & 0 & 4 & 2.96 \\
\hline 010802000301239469-1 & 0 & 4 & 3.64 \\
\hline 0108020110231 & 0 & 4 & 2.78 \\
\hline 010802000301234818-1 & 0 & 4 & 3.19 \\
\hline 010802000301234958-1 & 0 & 4 & 3.90 \\
\hline 010802000301239337-1 & 0 & 4 & 3.39 \\
\hline 0108020110166-1 & 0 & 4 & 2.12 \\
\hline
\end{tabular}




$\begin{array}{llll}0108020110268 & 0 & 4 & 2.28 \\ 010802000301238021-1 & 0 & 4 & 1.34 \\ 010802000301234959-1 & 0 & 4 & 1.99 \\ 0108020111019 & 0 & 4 & 1.37 \\ 010802000301234951-1 & 0 & 4 & 2.05 \\ 010802000301234814-1 & 0 & 4 & 2.15 \\ 0108020111018 & 1 & 5 & 1.05 \\ 010802000301234953-1 & 1 & 6 & 1.42 \\ 010802000301234810-1 & 1 & 7 & 1.47 \\ 010802000301234848-1 & 1 & 8 & 2.09 \\ 0108020110139-1 & 1 & 9 & 1.29\end{array}$

$\operatorname{Prob}(1,1,1,1,0,0,0,0,0,0,0,0,0,0,0,0,0,0,1,1,1,1,1 \mid$ Score $=9)=0.00002242$

Monte Carlo test of person fit: $p=0.611$

\begin{tabular}{|c|c|c|c|c|c|c|c|c|}
\hline \multirow{2}{*}{\multicolumn{2}{|c|}{ Item }} & \multicolumn{4}{|c|}{ Conditional probabilites } & \multicolumn{3}{|c|}{ Person estimates } \\
\hline & & & m score & cumul & ted score & WML & SEM & Next \\
\hline & 0108020111016 & 1 & 0.78583 & 1 & 0.78583 & & & \\
\hline & 0108020111022 & 1 & 0.54453 & 2 & 0.41834 & & & \\
\hline 3 & 0108020111006 & 1 & 0.58200 & 3 & 0.22663 & 3.18 & 0.80 & 4.05 \\
\hline 4 & $010802000301239468-1$ & 1 & 0.08004 & 4 & 0.01371 & 5.16 & 1.00 & 3.93 \\
\hline 5 & $010802000301234973-1$ & 0 & 0.91062 & 4 & 0.03023 & 4.08 & 1.12 & 2.96 \\
\hline 6 & $010802000301234876-1$ & 0 & 0.79076 & 4 & 0.07271 & 3.32 & 1.00 & 3.64 \\
\hline 7 & $010802000301239469-1$ & 0 & 0.88350 & 4 & 0.09861 & 3.02 & 0.90 & 2.78 \\
\hline 8 & 0108020110231 & 0 & 0.75660 & 4 & 0.15524 & 2.66 & 0.82 & 3.19 \\
\hline 9 & $010802000301234818-1$ & 0 & 0.82659 & 4 & 0.19538 & 2.46 & 0.77 & 3.90 \\
\hline 10 & $010802000301234958-1$ & 0 & 0.90786 & 4 & 0.21571 & 2.37 & 0.75 & 3.39 \\
\hline 11 & $010802000301239337-1$ & 0 & 0.85489 & 4 & 0.24648 & 2.25 & 0.72 & 2.12 \\
\hline 12 & 0108020110166-1 & 0 & 0.60989 & 4 & 0.31902 & 2.00 & 0.70 & 2.28 \\
\hline 13 & 0108020110268 & 0 & 0.64805 & 4 & 0.35660 & 1.82 & 0.68 & 1.34 \\
\hline 14 & $010802000301238021-1$ & 0 & 0.40575 & 4 & 0.34450 & 1.56 & 0.67 & 1.99 \\
\hline 15 & $010802000301234959-1$ & 0 & 0.57618 & 4 & 0.28145 & 1.41 & 0.65 & 1.37 \\
\hline 16 & 0108020111019 & 0 & 0.41327 & 4 & 0.15926 & 1.22 & 0.64 & 2.05 \\
\hline 17 & $010802000301234951-1$ & 0 & 0.59312 & 4 & 0.08206 & 1.11 & 0.63 & 2.15 \\
\hline 18 & $010802000301234814-1$ & 0 & 0.61792 & 4 & 0.02884 & 1.02 & 0.62 & 1.05 \\
\hline 19 & 0108020111018 & 1 & 0.66375 & 5 & 0.05406 & 1.18 & 0.57 & 1.42 \\
\hline 20 & $010802000301234953-1$ & 1 & 0.57321 & 6 & 0.11363 & 1.33 & 0.53 & 1.47 \\
\hline 21 & $010802000301234810-1$ & 1 & 0.56051 & 7 & 0.22822 & 1.46 & 0.51 & 2.09 \\
\hline 22 & $010802000301234848-1$ & 1 & 0.39903 & 8 & 0.60612 & 1.61 & 0.49 & 1.29 \\
\hline 23 & 0108020110139-1 & 1 & 0.60612 & 9 & 1.00000 & 1.70 & 0.47 & \\
\hline
\end{tabular}

Responses to items 1 to 4 are significant. $p=0.0137$

Person parameter will be estimated based on the subscore of items $5-23$

Rank correlation between person estimate and next item $=0.78$

Estimates of person parameter

Optimal SEM with 23 dichotomous items 0.417

$$
\begin{array}{rlll}
\text { WML } & =1.698 & \text { SEM }=0.469 & \text { Bias }=0.000 \\
\text { ML }=1.685 & \text { SEM }=0.489 & \text { Bias }=0.000
\end{array}
$$




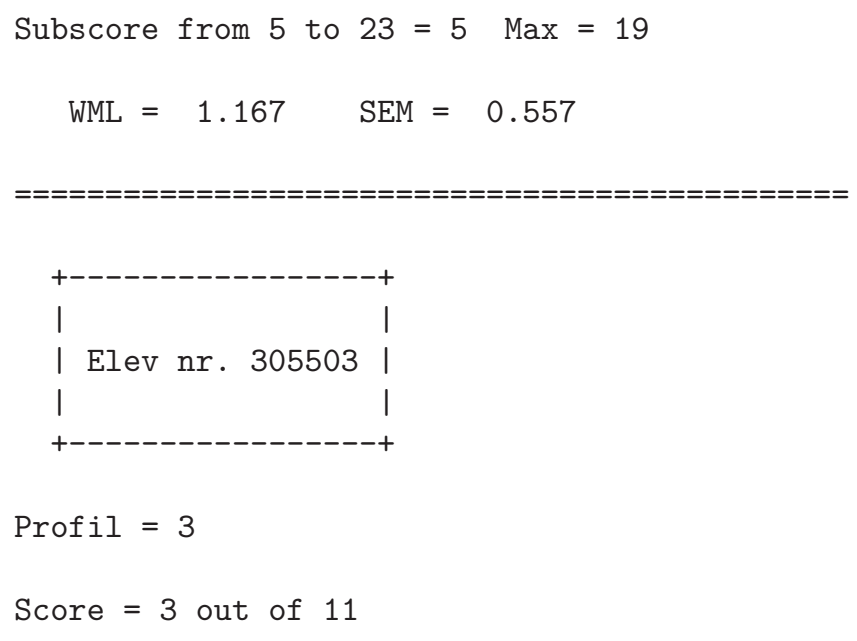

\begin{tabular}{lccc} 
Item & \multicolumn{3}{c}{ PCM } \\
01080306061330075 & 1 & 1 & 0.27 \\
01080306061330078 & 1 & 2 & -0.01 \\
$010803000301238868-1$ & 1 & 3 & 1.45 \\
$010803000301235585-2$ & 0 & 3 & 2.84 \\
$010803000301235768-1$ & 0 & 3 & 1.84 \\
$010803000301235607-2$ & 0 & 3 & 1.10 \\
$010803000301238349-1$ & 0 & 3 & 1.72 \\
$010803000301238838-1$ & 0 & 3 & 2.14 \\
$01080306910-122$ & 0 & 3 & 1.26 \\
$010803000301236033-2$ & 0 & 3 & 0.43 \\
$010803000301237450-3$ & 0 & 3 & 0.60
\end{tabular}

$\operatorname{Prob}(1,1,1,0,0,0,0,0,0,0,0 \mid$ Score $=3)=0.02131734$

Monte Carlo test of person fit: $p=0.748$

\begin{tabular}{|c|c|c|c|c|c|c|}
\hline \multirow[b]{2}{*}{ Item } & \multicolumn{3}{|c|}{ Conditional probabilites } & \multicolumn{3}{|c|}{ Person estimates } \\
\hline & Item score & cumul & ed score & WML & SEM & Next \\
\hline 101080306061330075 & 10.47906 & 1 & 0.47906 & & & \\
\hline 201080306061330078 & 0.56074 & 2 & 0.23230 & & & \\
\hline $3010803000301238868-1$ & 0.19633 & 3 & 0.02132 & 2.75 & 0.83 & 2.84 \\
\hline $4010803000301235585-2$ & 0.94654 & 3 & 0.02944 & 2.30 & 1.14 & 1.84 \\
\hline $5010803000301235768-1$ & 0.86223 & 3 & 0.05371 & 1.72 & 1.01 & 1.10 \\
\hline $6010803000301235607-2$ & 0.73674 & 3 & 0.11746 & 1.23 & 0.90 & 1.72 \\
\hline $7010803000301238349-1$ & 0.84562 & 3 & 0.16743 & 1.01 & 0.83 & 2.14 \\
\hline $8010803000301238838-1$ & 0.89521 & 3 & 0.20658 & 0.88 & 0.79 & 1.26 \\
\hline $901080306910-1 \_2$ & 0.76917 & 3 & 0.31169 & 0.67 & 0.76 & 0.43 \\
\hline $10010803000301236033-2$ & 0.56700 & 3 & 0.61362 & 0.40 & 0.74 & 0.60 \\
\hline $11010803000301237450-3$ & 0.61362 & 3 & 1.00000 & 0.19 & 0.72 & \\
\hline
\end{tabular}

Responses to items 1 to 3 are significant. $p=0.0213$

Person parameter will be estimated based on the subscore of items $4-11$

Rank correlation between person estimate and next item $=0.79$ 

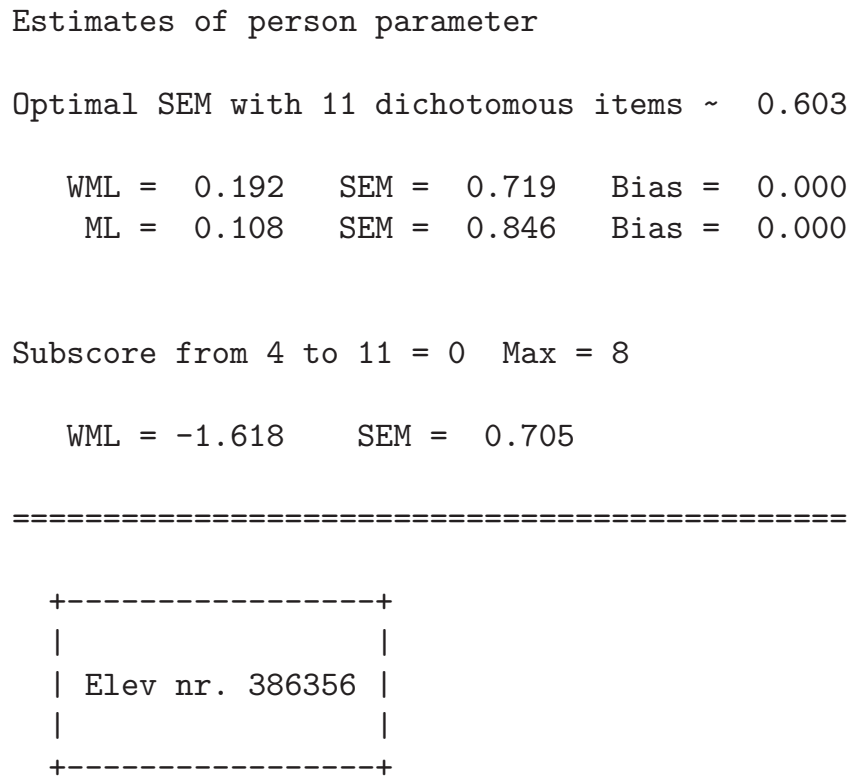

Profil $=1$

Score $=6$ out of 22

$\begin{array}{lccc}\text { Item } & & & \text { PCM } \\ 0108010420130 & \text { Score } & \text { Thresholds } \\ 010801000301238556-1 & 1 & 1 & 1.10 \\ 010801000301234839-1 & 1 & 2 & 1.34 \\ 0108010410315 & 0 & 3 & 1.66 \\ 010801000301239196-1 & 0 & 3 & 2.39 \\ 010801000301234841-1 & 0 & 3 & 0.88 \\ 0108010410094 & 0 & 3 & 0.86 \\ 0108010420122 & 0 & 3 & 1.14 \\ 0108010420160 & 0 & 3 & 1.67 \\ 010801000301238872-1 & 0 & 3 & 1.06 \\ 0108010415120 & 0 & 3 & 1.49 \\ 010801000301238996-1 & 0 & 3 & 0.28 \\ 010801000301238353-1 & 0 & 3 & -0.06 \\ 0108010420142 & 0 & 3 & 0.71 \\ 0108010420150 & 0 & 3 & -0.08 \\ 0108010415129 & 0 & 3 & -0.86 \\ 0108010410230009 & 0 & 3 & 0.08 \\ 010801000301238279-1 & 1 & 4 & -1.06 \\ 0108010420027 & 0 & 4 & -0.74 \\ 0108010440028 & 1 & 5 & -0.94 \\ 0108010415182 & 0 & 5 & -0.95 \\ 0108010410230021 & 1 & 6 & -0.59\end{array}$

$\operatorname{Prob}(1,1,1,0,0,0,0,0,0,0,0,0,0,0,0,0,0,1,0,1,0,1 \mid$ Score $=6)=0.000005245$

Monte Carlo test of person fit: $p=0.071$ 


\begin{tabular}{|c|c|c|c|c|c|c|c|c|}
\hline \multicolumn{2}{|c|}{ Item } & \multicolumn{2}{|c|}{ Item score } & \multicolumn{2}{|c|}{ cumulated score } & \multirow[t]{2}{*}{ WML } & \multirow[t]{2}{*}{ SEM } & \multirow[t]{2}{*}{ Next } \\
\hline 1 & 0108010420130 & 1 & 0.12922 & 1 & 0.12922 & & & \\
\hline 2 & 010801000301238556-1 & 1 & 0.10348 & 2 & 0.01058 & & & \\
\hline 3 & 010801000301234839-1 & 1 & 0.07744 & 3 & 0.00048 & 3.34 & 0.78 & 0.28 \\
\hline 4 & 0108010410315 & 0 & 0.74130 & 3 & 0.00431 & 2.02 & 0.99 & 2.39 \\
\hline 5 & 010801000301239196-1 & 0 & 0.96157 & 3 & 0.00608 & 1.74 & 0.95 & 0.88 \\
\hline 6 & 010801000301234841-1 & 0 & 0.84303 & 3 & 0.01474 & 1.27 & 0.86 & 0.86 \\
\hline 7 & 0108010410094 & 0 & 0.84076 & 3 & 0.02840 & 0.92 & 0.80 & 1.14 \\
\hline 8 & 0108010420122 & 0 & 0.87584 & 3 & 0.04286 & 0.70 & 0.76 & 1.67 \\
\hline 9 & 0108010420160 & 0 & 0.92342 & 3 & 0.05344 & 0.58 & 0.73 & 1.06 \\
\hline 10 & $010801000301238872-1$ & 0 & 0.86638 & 3 & 0.07404 & 0.41 & 0.71 & 1.49 \\
\hline 11 & 0108010415120 & 0 & 0.90964 & 3 & 0.08982 & 0.31 & 0.70 & 0.28 \\
\hline 12 & 010801000301238996-1 & 0 & 0.74130 & 3 & 0.14047 & 0.10 & 0.69 & -0.06 \\
\hline 13 & 010801000301238353-1 & 0 & 0.66628 & 3 & 0.21700 & -0.13 & 0.68 & 0.71 \\
\hline 14 & 0108010420142 & 0 & 0.81773 & 3 & 0.26030 & -0.24 & 0.67 & -0.08 \\
\hline 15 & 0108010420150 & 0 & 0.66181 & 3 & 0.33570 & -0.43 & 0.67 & -0.86 \\
\hline 16 & 0108010415129 & 0 & 0.45998 & 3 & 0.40596 & -0.67 & 0.67 & 0.08 \\
\hline 17 & 0108010410230009 & 0 & 0.69992 & 3 & 0.40268 & -0.79 & 0.67 & -1.06 \\
\hline 18 & $010801000301238279-1$ & 1 & 0.59420 & 4 & 0.43484 & -0.65 & 0.61 & -0.74 \\
\hline 19 & 0108010420027 & 0 & 0.49228 & 4 & 0.43432 & -0.83 & 0.61 & -0.94 \\
\hline 20 & 0108010440028 & 1 & 0.56189 & 5 & 0.54022 & -0.69 & 0.56 & -0.95 \\
\hline 21 & 0108010415182 & 0 & 0.43426 & 5 & 0.46926 & -0.86 & 0.56 & -0.59 \\
\hline 22 & 0108010410230021 & 1 & 0.46926 & 6 & 1.00000 & -0.71 & 0.52 & \\
\hline
\end{tabular}

Responses to items 1 to 3 are significant. $p=0.0005$

Person parameter will be estimated based on the subscore of items $4-22$

Rank correlation between person estimate and next item $=0.80$

Estimates of person parameter

Optimal SEM with 22 dichotomous items 0.426

WML $=-0.708 \quad$ SEM $=0.522 \quad$ Bias $=0.000$

ML $=-0.750 \quad$ SEM $=0.564 \quad$ Bias $=0.000$

Subscore from 4 to $22=3 \quad$ Max $=19$

WML $=-1.568 \quad$ SEM $=0.661$

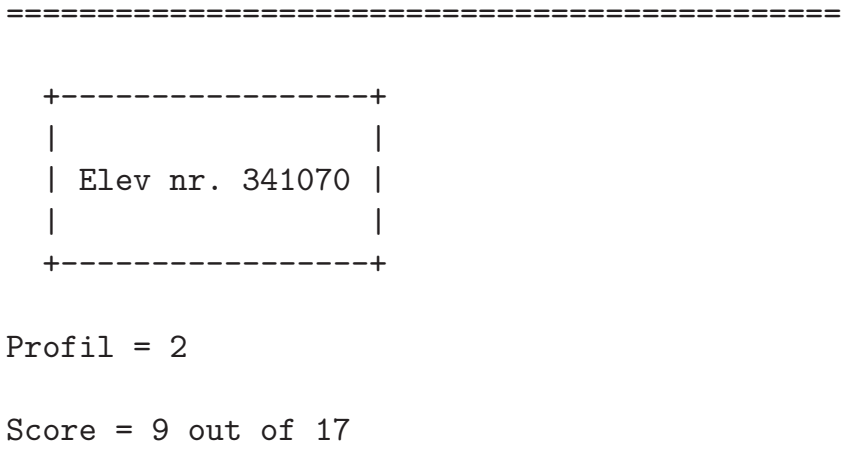

PCM 


$\begin{array}{lrrc}\text { Item } & \text { Score } & \text { Thresholds } \\ 0108020111016 & 1 & 1 & 0.46 \\ 0108020111022 & 1 & 2 & 1.53 \\ 010802000301238021-1 & 1 & 3 & 1.34 \\ 010802000301239468-1 & 0 & 3 & 4.05 \\ 0108020110231 & 0 & 3 & 2.78 \\ 010802000301234818-1 & 0 & 3 & 3.19 \\ 0108020110166-1 & 0 & 3 & 2.12 \\ 0108020110268 & 0 & 3 & 2.28 \\ 0108020111006 & 1 & 4 & 1.39 \\ 010802000301239338-1 & 1 & 5 & 2.98 \\ 010802000301239337-1 & 0 & 5 & 3.39 \\ 010802000301234958-1 & 0 & 5 & 3.90 \\ 010802000301234959-1 & 0 & 5 & 1.99 \\ 0108020110139-1 & 1 & 6 & 1.29 \\ 010802000301234951-1 & 1 & 7 & 2.05 \\ 010802000301234848-1 & 1 & 8 & 2.09 \\ 0108020111019 & 1 & 9 & 1.37 \\ & \end{array}$

\begin{tabular}{|c|c|c|c|c|c|c|c|c|}
\hline \multirow{2}{*}{\multicolumn{2}{|c|}{ Item }} & \multicolumn{4}{|c|}{ Conditional probabilites } & \multicolumn{3}{|c|}{ Person estimates } \\
\hline & & & m score & cumul & ted score & WML & SEM & Next \\
\hline & 0108020111016 & 1 & 0.88171 & 1 & 0.88171 & & & \\
\hline 2 & 0108020111022 & 1 & 0.70934 & 2 & 0.61919 & & & \\
\hline 3 & $010802000301238021-1$ & 1 & 0.74940 & 3 & 0.44915 & 3.17 & 0.80 & 4.05 \\
\hline 4 & 010802000301239468-1 & 0 & 0.85686 & 3 & 0.46633 & 3.04 & 1.21 & 2.78 \\
\hline 5 & 0108020110231 & 0 & 0.61011 & 3 & 0.47697 & 2.44 & 1.05 & 3.19 \\
\hline 6 & $010802000301234818-1$ & 0 & 0.70859 & 3 & 0.44246 & 2.21 & 0.94 & 2.12 \\
\hline 7 & 0108020110166-1 & 0 & 0.43564 & 3 & 0.31543 & 1.85 & 0.86 & 2.28 \\
\hline 8 & 0108020110268 & 0 & 0.47717 & 3 & 0.17868 & 1.63 & 0.81 & 1.39 \\
\hline 9 & 0108020111006 & 1 & 0.73979 & 4 & 0.24432 & 1.84 & 0.74 & 2.98 \\
\hline 10 & 010802000301239338-1 & 1 & 0.33949 & 5 & 0.39772 & 2.20 & 0.70 & 3.39 \\
\hline 11 & $010802000301239337-1$ & 0 & 0.75146 & 5 & 0.36250 & 2.11 & 0.67 & 3.90 \\
\hline 12 & $010802000301234958-1$ & 0 & 0.83653 & 5 & 0.33098 & 2.06 & 0.66 & 1.99 \\
\hline 13 & 010802000301234959-1 & 0 & 0.40099 & 5 & 0.14729 & 1.86 & 0.63 & 1.29 \\
\hline 14 & 0108020110139-1 & 1 & 0.75857 & 6 & 0.21622 & 1.98 & 0.60 & 2.05 \\
\hline 15 & 010802000301234951-1 & 1 & 0.58183 & 7 & 0.41198 & 2.15 & 0.57 & 2.09 \\
\hline 16 & $010802000301234848-1$ & 1 & 0.57371 & 8 & 0.74353 & 2.29 & 0.55 & 1.37 \\
\hline 17 & 0108020111019 & 1 & 0.74353 & 9 & 1.00000 & 2.36 & 0.54 & \\
\hline
\end{tabular}

Nothing unexpected during the start or end of the test

Rank correlation between person estimate and next item $=0.65$

Estimates of person parameter

Optimal SEM with 17 dichotomous items 0.485

$$
\begin{array}{rlll}
\text { WML } & =2.361 & \text { SEM }=0.536 & \text { Bias }=0.000 \\
\text { ML }=2.370 & \text { SEM }=0.562 & \text { Bias }=0.000
\end{array}
$$




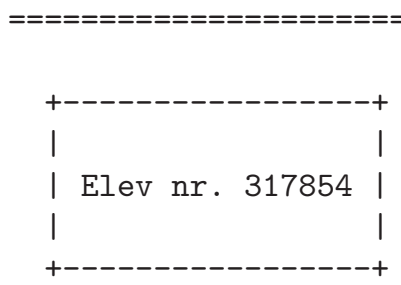

Profil $=2$

Score $=15$ out of 32

Thresholds are PCM parameters

\begin{tabular}{lrrc} 
& \multicolumn{3}{c}{ PCM } \\
Item & Score & Thresholds \\
0108020111018 & 1 & 1 & 1.05 \\
$010802000301234810-1$ & 1 & 2 & 1.47 \\
0108020111006 & 1 & 3 & 1.39 \\
$010802000301239468-1$ & 0 & 3 & 4.05 \\
0108020110231 & 0 & 3 & 2.78 \\
$010802000301234818-1$ & 0 & 3 & 3.19 \\
$0108020110166-1$ & 0 & 3 & 2.12 \\
0108020110268 & 0 & 3 & 2.28 \\
$010802000301238021-1$ & 1 & 4 & 1.34 \\
$010802000301239338-1$ & 1 & 5 & 2.98 \\
$010802000301239337-1$ & 0 & 5 & 3.39 \\
$010802000301234958-1$ & 0 & 5 & 3.90 \\
$010802000301234959-1$ & 0 & 5 & 1.99 \\
$0108020110139-1$ & 1 & 6 & 1.29 \\
$010802000301234951-1$ & 1 & 7 & 2.05 \\
$010802000301234848-1$ & 1 & 8 & 2.09 \\
0108020111019 & 1 & 9 & 1.37 \\
0108020111022 & 0 & 9 & 1.53 \\
0108020111026 & 1 & 10 & 0.87 \\
$010802000301234814-1$ & 0 & 10 & 2.15 \\
$010802000301234953-1$ & 1 & 11 & 1.42 \\
0108020110266 & 1 & 12 & 0.58 \\
$010802000301234788-1$ & 1 & 13 & 1.35 \\
$010802000301234941-1$ & 0 & 13 & 1.39 \\
$0108020110150-1$ & 1 & 14 & 1.14 \\
$0108020110083-1$ & 0 & 14 & 1.30 \\
0108020111016 & 1 & 15 & 0.46 \\
$010802000301234966-1$ & 0 & 15 & 1.37 \\
0108020115072 & 0 & 15 & 1.38 \\
0108020111032 & 0 & 15 & 0.29 \\
$0108020110027-1$ & 0 & 15 & 1.50 \\
0108020111024 & 0 & 15 & 0.42 \\
& & &
\end{tabular}

$\operatorname{Prob}(1,1,1,0,0,0,0,0,1,1,0,0,0,1,1,1,1,0,1,0,1,1,1,0,1,0,1,0,0,0,0,0 \mid$ Score = 15) = 0.00000001464 Monte Carlo test of person fit: $p=0.397$ 


\begin{tabular}{|c|c|c|c|c|c|c|c|}
\hline \multicolumn{2}{|c|}{ Item } & Item score & \multicolumn{2}{|c|}{ cumulated score } & \multirow[t]{3}{*}{ WML } & \multirow[t]{3}{*}{ SEM } & \multirow[t]{2}{*}{ Next } \\
\hline 1 & 0108020111018 & 10.62703 & 1 & 0.62703 & & & \\
\hline 2 & 010802000301234810-1 & 0.52247 & 2 & 0.31861 & & & \\
\hline 3 & 0108020111006 & 0.54391 & 3 & 0.16247 & 3.27 & 0.78 & 4.05 \\
\hline 4 & 010802000301239468-1 & 0.92793 & 3 & 0.18287 & 3.10 & 1.19 & 2.78 \\
\hline 5 & 0108020110231 & 0.77922 & 3 & 0.24135 & 2.51 & 1.03 & 3.19 \\
\hline 6 & $010802000301234818-1$ & 0.84327 & 3 & 0.27372 & 2.28 & 0.92 & 2.12 \\
\hline 7 & 0108020110166-1 & 0.64253 & 3 & 0.32945 & 1.93 & 0.85 & 2.28 \\
\hline 8 & 0108020110268 & 0.67847 & 3 & 0.34664 & 1.70 & 0.79 & 1.34 \\
\hline 9 & $010802000301238021-1$ & 0.55621 & 4 & 0.29032 & 1.89 & 0.73 & 2.98 \\
\hline 10 & $010802000301239338-1$ & 0.18707 & 5 & 0.16051 & 2.24 & 0.69 & 3.39 \\
\hline 11 & $010802000301239337-1$ & 0.86902 & 5 & 0.18088 & 2.15 & 0.67 & 3.90 \\
\hline 12 & $010802000301234958-1$ & 0.91700 & 5 & 0.19327 & 2.09 & 0.65 & 1.99 \\
\hline 13 & 010802000301234959-1 & 0.61051 & 5 & 0.24811 & 1.90 & 0.63 & 1.29 \\
\hline 14 & 0108020110139-1 & 0.56818 & 6 & 0.18805 & 2.01 & 0.60 & 2.05 \\
\hline 15 & $010802000301234951-1$ & 0.37336 & 7 & 0.10679 & 2.17 & 0.57 & 2.09 \\
\hline 16 & $010802000301234848-1$ & 0.36591 & 8 & 0.04952 & 2.31 & 0.55 & 1.37 \\
\hline 17 & 0108020111019 & 0.54866 & 9 & 0.02520 & 2.38 & 0.53 & 1.53 \\
\hline 18 & 0108020111022 & 0.49337 & 9 & 0.05363 & 2.20 & 0.51 & 0.87 \\
\hline 19 & 0108020111026 & 0.67088 & 10 & 0.03241 & 2.25 & 0.50 & 2.15 \\
\hline 20 & $010802000301234814-1$ & 0.65012 & 10 & 0.05311 & 2.13 & 0.49 & 1.42 \\
\hline 21 & $010802000301234953-1$ & 0.53513 & 11 & 0.02447 & 2.20 & 0.48 & 0.58 \\
\hline 22 & 0108020110266 & 0.73230 & 12 & 0.01363 & 2.23 & 0.47 & 1.35 \\
\hline 23 & $010802000301234788-1$ & 0.55381 & 13 & 0.00428 & 2.29 & 0.46 & 1.39 \\
\hline 24 & $010802000301234941-1$ & 0.45808 & 13 & 0.01168 & 2.15 & 0.45 & 1.14 \\
\hline 25 & 0108020110150-1 & 0.60603 & 14 & 0.00317 & 2.20 & 0.44 & 1.30 \\
\hline 26 & 0108020110083-1 & 0.43494 & 14 & 0.00932 & 2.07 & 0.43 & 0.46 \\
\hline 27 & 0108020111016 & 0.75625 & 15 & 0.00252 & 2.10 & 0.42 & 1.37 \\
\hline 28 & 010802000301234966-1 & 0.45218 & 15 & 0.00729 & 1.98 & 0.41 & 1.38 \\
\hline 29 & 0108020115072 & 0.45581 & 15 & 0.01951 & 1.88 & 0.40 & 0.29 \\
\hline 30 & 0108020111032 & 0.21346 & 15 & 0.10768 & 1.75 & 0.40 & 1.50 \\
\hline 31 & 0108020110027-1 & 0.48517 & 15 & 0.23613 & 1.67 & 0.39 & 0.42 \\
\hline 32 & 0108020111024 & 0.23613 & 15 & 1.00000 & 1.56 & 0.38 & \\
\hline
\end{tabular}

Nothing unexpected during the start or end of the test

Rank correlation between person estimate and next item $=0.64$

Estimates of person parameter

Optimal SEM with 32 dichotomous items 0.354

WML $=1.556 \quad$ SEM $=0.384$ Bias $=0.000$

$\mathrm{ML}=1.555 \quad \mathrm{SEM}=0.394 \quad$ Bias $=0.000$ 


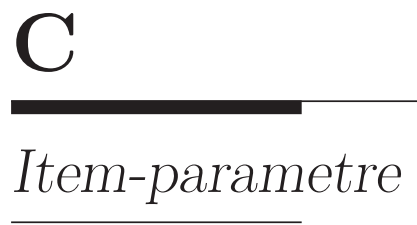

Dette bilag viser itemsværhedsgraderne ifølge 2017-analysen. Beta er itemmets sværhedsgrad, t.1-t.7 er thresholds/step-parametrene for polytome items. se.t.1-se.t.7 er standardmålefejlen for parametrene. Derefter vises DNT's estimater af itemsværhedsgraderne. For partial credit items er værdierne angivet som såkaldte ucentraliserede thresholdværdier der ikke har en let fortolkning (det er skæringspunkterne mellem de såkaldte itemkarakteristiske kurver). Værdierne kan omregnes til såkaldte Thurstonian thresholds hvorved de er lettere at fortolke. Dette har ikke været nødvendigt for analyserne i denne rapport. 
Tabel C.1: Item-parametre

\begin{tabular}{|c|c|c|c|c|c|c|c|c|c|c|c|c|c|c|c|c|c|c|c|c|c|c|c|}
\hline Opgavenummer & Beta 2017 & t.1 & $\mathrm{t} .2$ & t. 3 & t.4 & t.5 & t.6 & t.7 & Beta dnt & dnt. 1 & dnt.2 & dnt. 3 & dnt. 4 & $\mathrm{dnt} .5$ & dnt. 6 & $\mathrm{dnt} .7$ & se.t.1 & se.t. 2 & se.t. 3 & se.t. 4 & se.t. 5 & se.t. 6 & se.t.7 \\
\hline $010801000301234789-1$ & 1,447 & 1,447 & & & & & & & 1,202 & 1,202 & & & & & & & 0,041 & & & & & & \\
\hline 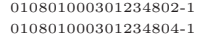 & $\begin{array}{l}1,480 \\
1,165\end{array}$ & $\begin{array}{l}1,480 \\
1,165\end{array}$ & & & & & & & $\begin{array}{l}1,563 \\
1,505\end{array}$ & $\begin{array}{l}1,563 \\
1,505\end{array}$ & & & & & & & 0,032 & & & & & & \\
\hline & $\begin{array}{l}1,165 \\
0,204\end{array}$ & $\begin{array}{l}1,165 \\
0,204\end{array}$ & & & & & & & $\begin{array}{l}1,505 \\
0.628\end{array}$ & $\begin{array}{l}1,505 \\
0.628\end{array}$ & & & & & & & $\begin{array}{l}0,035 \\
0.037\end{array}$ & & & & & & \\
\hline $010801000301234807-1$ & $\begin{array}{l}0,204 \\
0,901\end{array}$ & $\begin{array}{l}0,204 \\
0,901\end{array}$ & & & & & & & $\begin{array}{l}1,688 \\
1,566\end{array}$ & $\begin{array}{l}0,628 \\
1,566\end{array}$ & & & & & & & $\begin{array}{l}0,037 \\
0,031\end{array}$ & & & & & & \\
\hline 010801000301234815-1 & 0,898 & 0,898 & & & & & & & 0,800 & 0,800 & & & & & & & 0,045 & & & & & & \\
\hline $010801000301234817-1$ & 1,506 & 1,506 & & & & & & & 1,346 & 1,346 & & & & & & & 0,042 & & & & & & \\
\hline $\begin{array}{l}010801000301234820-1 \\
010800000301234823-1\end{array}$ & $\begin{array}{l}0,535 \\
1,235\end{array}$ & $\begin{array}{l}0,535 \\
1,235\end{array}$ & & & & & & & $\begin{array}{l}1,552 \\
109\end{array}$ & $\begin{array}{l}1,552 \\
1097\end{array}$ & & & & & & & 0,034 & & & & & & \\
\hline $\begin{array}{l}0108010000001234823-1 \\
010801000301234824-1\end{array}$ & $\begin{array}{l}1,235 \\
0,581\end{array}$ & $\begin{array}{l}1,235 \\
0,581\end{array}$ & & & & & & & $\begin{array}{l}1,0079 \\
1,685\end{array}$ & $\begin{array}{l}1,0079 \\
1,685\end{array}$ & & & & & & & $\begin{array}{l}0,038 \\
0,027\end{array}$ & & & & & & \\
\hline $010801000301234825-1$ & 1,164 & 1,164 & & & & & & & 1,288 & 1,288 & & & & & & & 0,043 & & & & & & \\
\hline 010801000301234826-1 & 1,068 & 1,068 & & & & & & & 1,396 & 1,396 & & & & & & & 0,039 & & & & & & \\
\hline $010801000301234828-1$ & 0,776 & 0,776 & & & & & & & 1,912 & ${ }^{1,912}$ & & & & & & & 0,026 & & & & & & \\
\hline $\begin{array}{l}010801000301234829-1 \\
0.10800000301234830-1\end{array}$ & 1,138 & 1,138 & & & & & & & 1,634 & 1,634 & & & & & & & 0,029 & & & & & & \\
\hline 010801000301234830-1 & $-1,701$ & $-1,701$ & & & & & & & $-1,449$ & $-1,449$ & & & & & & & 0,033 & & & & & & \\
\hline $010801000301234831-1$ & 1,010 & 1,010 & & & & & & & 0,811 & 0,811 & & & & & & & 0,044 & & & & & & \\
\hline 010801000301234832-1 & 0,763 & 0,763 & & & & & & & 0,554 & 0,554 & & & & & & & 0,028 & & & & & & \\
\hline & 0,711 & 0,711 & & & & & & & 1,937 & 1,937 & & & & & & & 0,026 & & & & & & \\
\hline $\begin{array}{l}010801000301234835-1 \\
010801000301234836-1\end{array}$ & $-0,655$ & $-0,655$ & & & & & & & $-0,286$ & $-0,286$ & & & & & & & 0,028 & & & & & & \\
\hline 010801000301234836-1 & ${ }^{1,179}$ & 1,179 & & & & & & & 0,875 & 0,875 & & & & & & & 0,046 & & & & & & \\
\hline $010801000301234837-1$ & 1,240 & 1,240 & & & & & & & 2,263 & 2,263 & & & & & & & 0,026 & & & & & & \\
\hline 010801000301234838-1 & 1,046 & 1,046 & & & & & & & 0,930 & 0,930 & & & & & & & 0,036 & & & & & & \\
\hline $010801000301234839-1$ & 1,655 & 1,655 & & & & & & & 1,495 & 1,495 & & & & & & & 0,035 & & & & & & \\
\hline $\begin{array}{l}\begin{array}{l}0100801000301234840-1 \\
01080000301234841-1\end{array}\end{array}$ & $\begin{array}{l}1,261 \\
0,879\end{array}$ & $\begin{array}{l}1,281 \\
0,879\end{array}$ & & & & & & & $\begin{array}{l}1,155 \\
2,248\end{array}$ & $\begin{array}{l}1,155 \\
2,248\end{array}$ & & & & & & & $\begin{array}{l}0,043 \\
0.026\end{array}$ & & & & & & \\
\hline 010801000301234842-1 & 0,973 & 0,973 & & & & & & & 0,879 & 0,879 & & & & & & & 0.045 & & & & & & \\
\hline 010801000301234843-1 & 1,115 & 1,115 & & & & & & & 1,463 & 1,463 & & & & & & & 0,036 & & & & & & \\
\hline $010801000301236064-1$ & $-1,931$ & $\begin{array}{r}-1,931 \\
-1,930\end{array}$ & & & & & & & $-1,876$ & $\begin{array}{r}-1,876 \\
1,649\end{array}$ & & & & & & & 0,042 & & & & & & \\
\hline $\begin{array}{l}01080100000101236068-1 \\
01080100302123673-1\end{array}$ & $\begin{array}{l}1,939 \\
1.871\end{array}-\mathrm{C}$ & $\begin{array}{l}1,939 \\
1,871\end{array}-2$ & & & & & & & $\begin{array}{l}1,649 \\
1.532\end{array}-1$ & $\begin{array}{l}1,649 \\
1.532\end{array}$ & & & & & & & $\begin{array}{l}0,028 \\
0.034\end{array}-3$ & & & & & & \\
\hline $010801000301238277-1$ & -0.470 & -0.470 & & & & & & & $-0,680$ & -0.680 & & & & & & & 0.031 & & & & & & \\
\hline $010801000301238278-1$ & $\begin{array}{l}-0,460 \\
-1,662\end{array}$ & $-1,662$ & & & & & & & -1.064 & -1.064 & & & & & & & 0,034 & & & & & & \\
\hline $010801000301238279-1$ & $\begin{array}{r}-1,002 \\
-1,063\end{array}$ & $\begin{array}{l}-1,002 \\
-1,063\end{array}$ & & & & & & & $\begin{array}{l}-1,064 \\
-0,779\end{array}$ & $\begin{array}{l}-1,064 \\
-0,779\end{array}$ & & & & & & & $\begin{array}{l}0,034 \\
0,035\end{array}$ & & & & & & \\
\hline $010801000301238281-1$ & 0,764 & 0,764 & & & & & & & 0,745 & 0,745 & & & & & & & 0,041 & & & & & & \\
\hline $010801000301238282-1$ & 0,708 & 0,708 & & & & & & & 0,326 & 0,326 & & & & & & & 0,034 & & & & & & \\
\hline 010801000301238283-1 & $-0,590$ & $-0,590$ & & & & & & & $-0,944$ & $-0,944$ & & & & & & & 0,033 & & & & & & \\
\hline 010801000301238285-1 & $-0,950$ & $-0,950$ & & & & & & & $-0,576$ & $-0,576$ & & & & & & & 0,029 & & & & & & \\
\hline $010801000301238353-1$ & $-0,062$ & $-0,062$ & & & & & & & 0,232 & 0,232 & & & & & & & 0,033 & & & & & & \\
\hline $\begin{array}{l}\begin{array}{l}01080100003012385555-1 \\
018000000301238556-1\end{array}\end{array}$ & $\begin{array}{l}0,300 \\
1,344\end{array}-\square$ & $\begin{array}{l}0,300 \\
1,344\end{array}-\square$ & & & & & & & $\begin{array}{l}0,479 \\
11,075\end{array}$ & $\begin{array}{l}0,479 \\
1.075\end{array}$ & & & & & & & $\begin{array}{l}0,028 \\
0.038\end{array}-3$ & & & & & & \\
\hline $010801000301238607-1$ & 0.930 & 0,930 & & & & & & & 0.591 & 0.591 & & & & & & & 0.029 & & & & & & \\
\hline $010801000301238835-1$ & 1,278 & 1,278 & & & & & & & 0,775 & 0,775 & & & & & & & 0,044 & & & & & & \\
\hline $010801000301238836-1$ & 1,335 & 1,335 & & & & & & & 0,862 & 0,862 & & & & & & & 0,047 & & & & & & \\
\hline $010801000301238837-1$ & 0,254 & 0,254 & & & & & & & $-0,178$ & $-0,178$ & & & & & & & 0,029 & & & & & & \\
\hline 010801000301238839-1 & 1,065 & 1,065 & & & & & & & 0,735 & 0,735 & & & & & & & 0,042 & & & & & & \\
\hline $010801000301238862-1$ & 1,802 & 1,802 & & & & & & & 1,248 & 1,248 & & & & & & & 0,044 & & & & & & \\
\hline $010801000301238872-1$ & 1,062 & 1,062 & & & & & & & 1,003 & 1,003 & & & & & & & 0,034 & & & & & & \\
\hline 010801000301238873-1 & 1,258 & 1,258 & & & & & & & 0,843 & 0,843 & & & & & & & 0,046 & & & & & & \\
\hline 010801000301238920-1 & $\begin{array}{l}1,710 \\
1,49\end{array}$ & $\begin{array}{l}1,710 \\
1,497\end{array}$ & & & & & & & $\begin{array}{l}1,299 \\
1,306\end{array}$ & 1,299 & & & & & & & 0,045 & & & & & & \\
\hline 010801000301238923-1 & 1,497 & 1,497 & & & & & & & 1,306 & 1,306 & & & & & & & 0,044 & & & & & & \\
\hline 010801000301238925-1 & 1,346 & 1,346 & & & & & & & $\begin{array}{l}0,743 \\
-0463\end{array}$ & ${ }^{0,743}$ & & & & & & & 0,043 & & & & & & \\
\hline $010801000301238927-1$ & 0,466 & 0,466 & & & & & & & 0,463 & 0,463 & & & & & & & 0,029 & & & & & & \\
\hline 010801000301238994-1 & $-1,044$ & $-1,044$ & & & & & & & $-0,652$ & $-0,652$ & & & & & & & 0,032 & & & & & & \\
\hline $\begin{array}{l}01800100000012389995-1 \\
010800000301283996-1\end{array}$ & $\begin{array}{r}-0,265 \\
0,279\end{array}$ & $\left.\begin{array}{rl}-0,265 \\
0,279\end{array}\right]$ & & & & & & & $\begin{array}{r}-0,216 \\
0,448\end{array}$ & $\begin{array}{r}-0,216 \\
0,448\end{array}$ & & & & & & & $\begin{array}{l}0,027 \\
0,028\end{array}$ & & & & & & \\
\hline $010801000301238997-1$ & 1,837 & 1,837 & & & & & & & 1,445 & 1,445 & & & & & & & 0,036 & & & & & & \\
\hline $010801000301238999-1$ & 0,940 & 0,940 & & & & & & & 0,836 & 0,836 & & & & & & & 0,045 & & & & & & \\
\hline 1010801000301239000-1 & 1,452 & 1,452 & & & & & & & 1,367 & 1,367 & & & & & & & 0,041 & & & & & & \\
\hline 010801000301239195-1 & 1,319 & $\begin{array}{l}1,319 \\
2,280\end{array}$ & & & & & & & 0,760 & $\begin{array}{l}0,760 \\
2371\end{array}$ & & & & & & & 0,044 & & & & & & \\
\hline 010801000301239196-1 & 2,388 & 2,388 & & & & & & & 2,371 & 2,371 & & & & & & & 0,027 & & & & & & \\
\hline 010801000301239197-1 & $-0,117$ & $-0,117$ & & & & & & & $-0,073$ & $-0,073$ & & & & & & & 0,029 & & & & & & \\
\hline 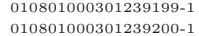 & $\begin{array}{r}-1,510 \\
-0,956\end{array}$ & $\begin{array}{l}-1,510 \\
-0,956\end{array}$ & & & & & & & $\begin{array}{l}-1,527 \\
-0.834\end{array}$ & $\begin{array}{l}-1,527 \\
-0,834\end{array}$ & & & & & & & $\begin{array}{l}0,036 \\
0,031\end{array}$ & & & & & & \\
\hline
\end{tabular}


Tabel C.1: Item-parametre (continued)

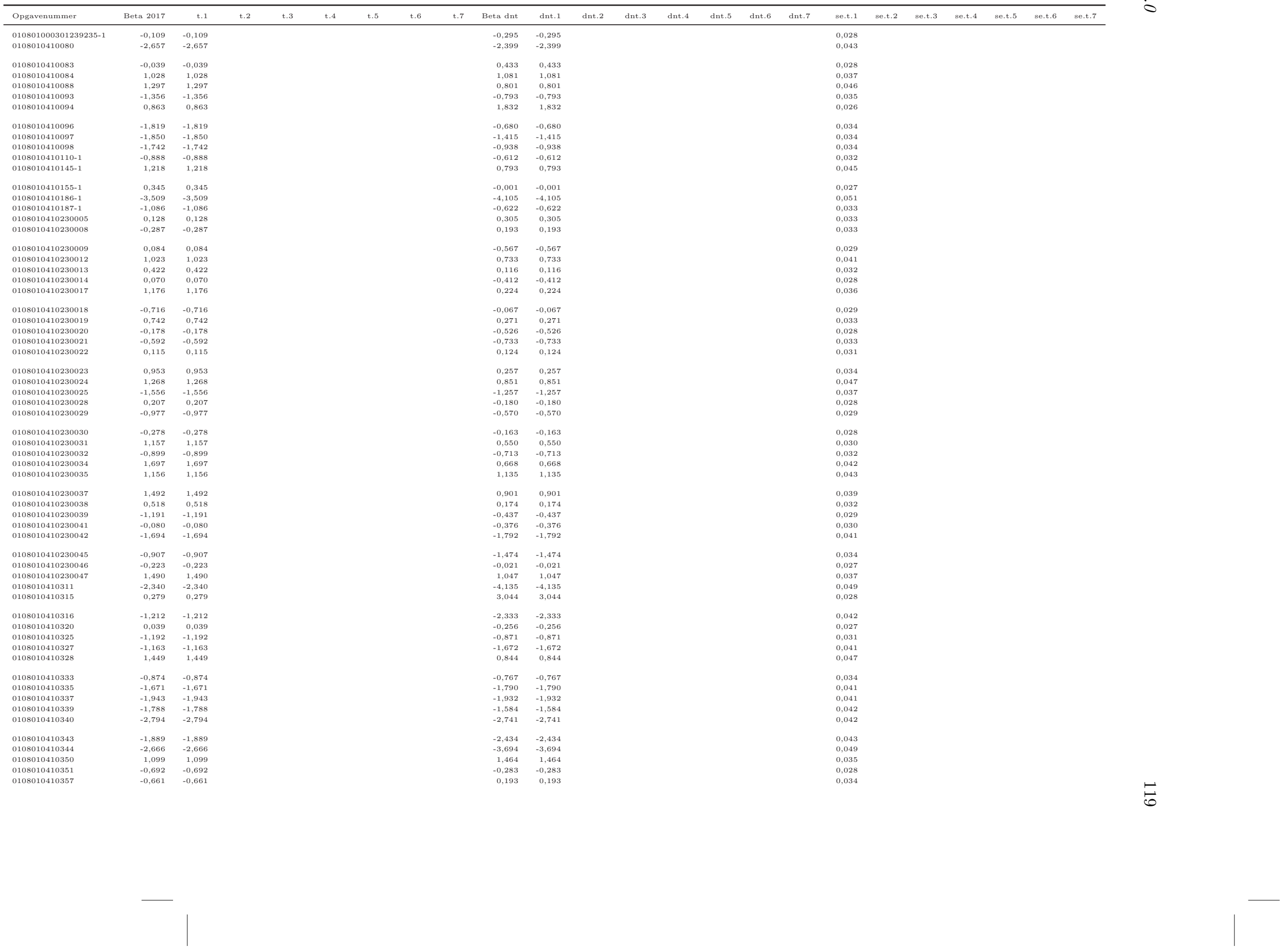


Tabel C.1: Item-parametre (continued)

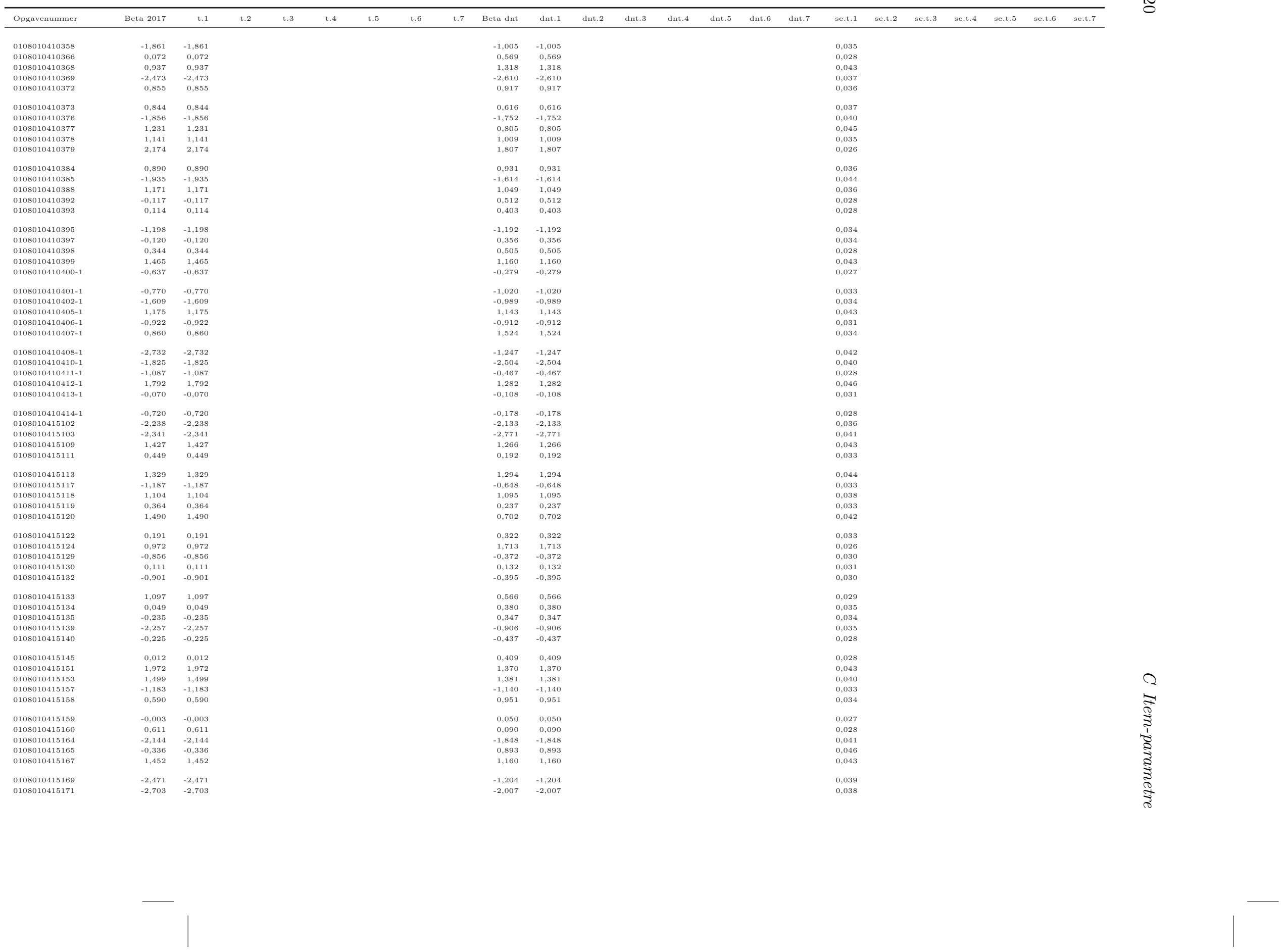


Tabel C.1: Item-parametre (continued)

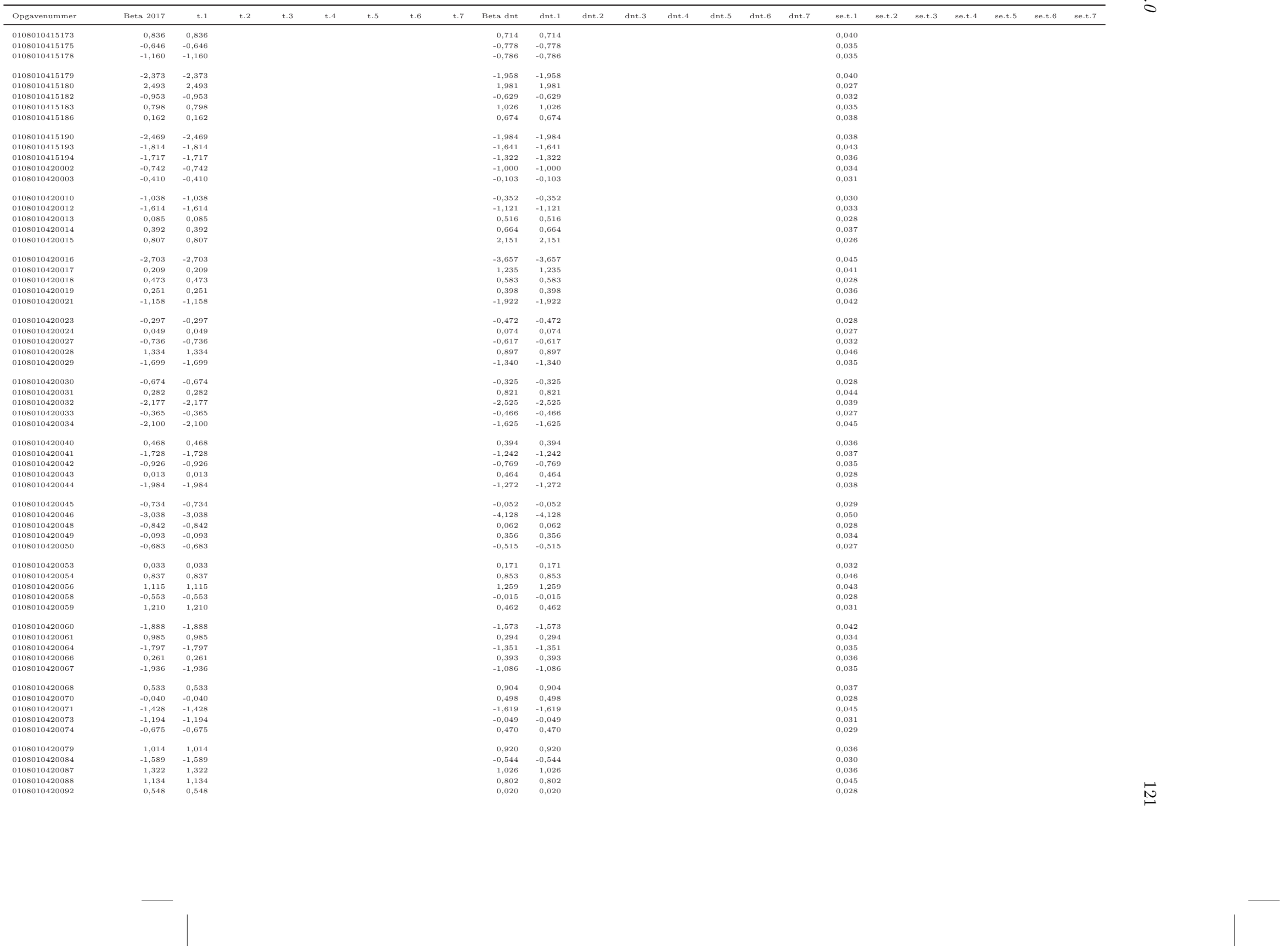


Tabel C.1: Item-parametre (continued)

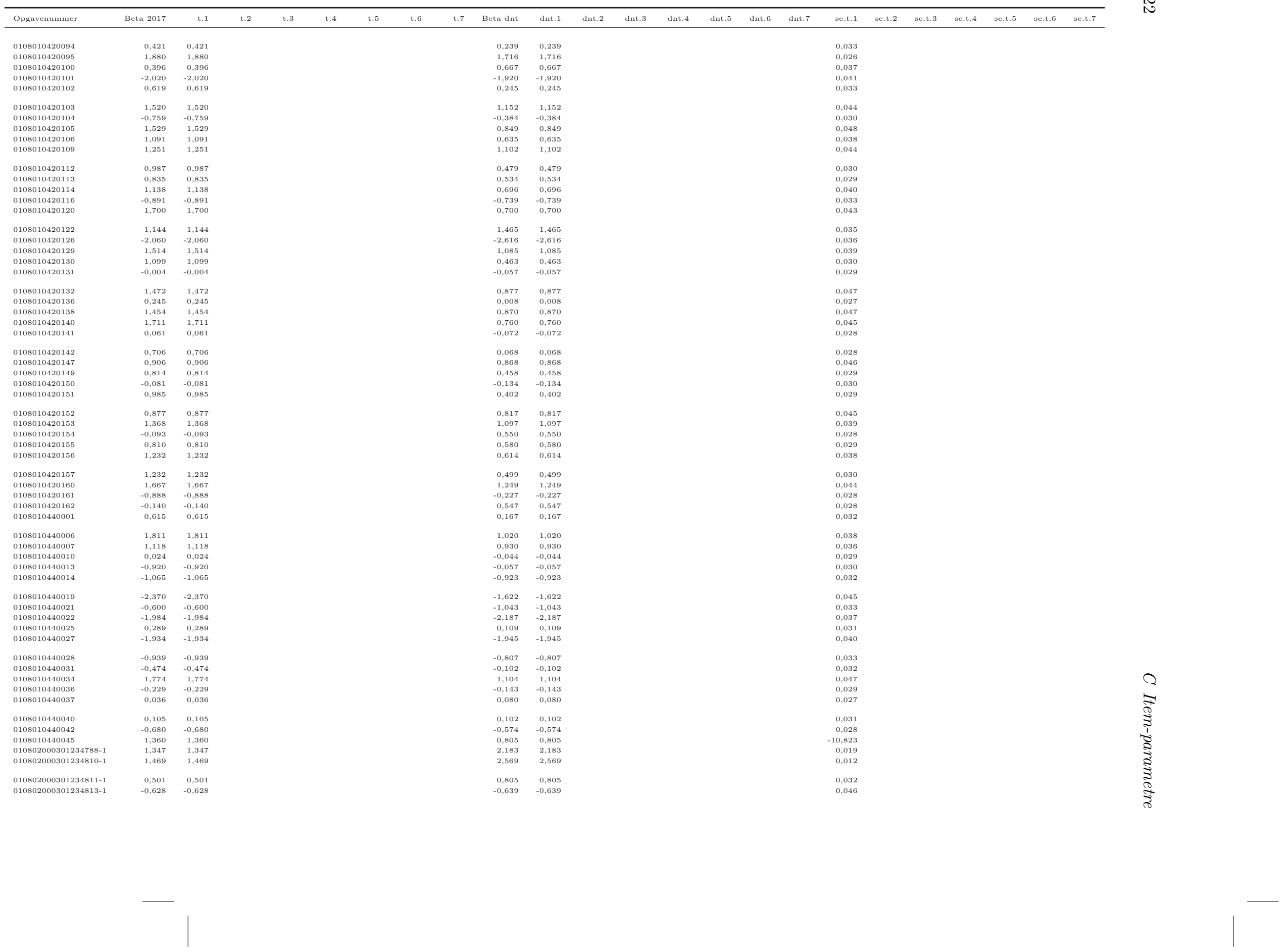


Tabel C.1: Item-parametre (continued)

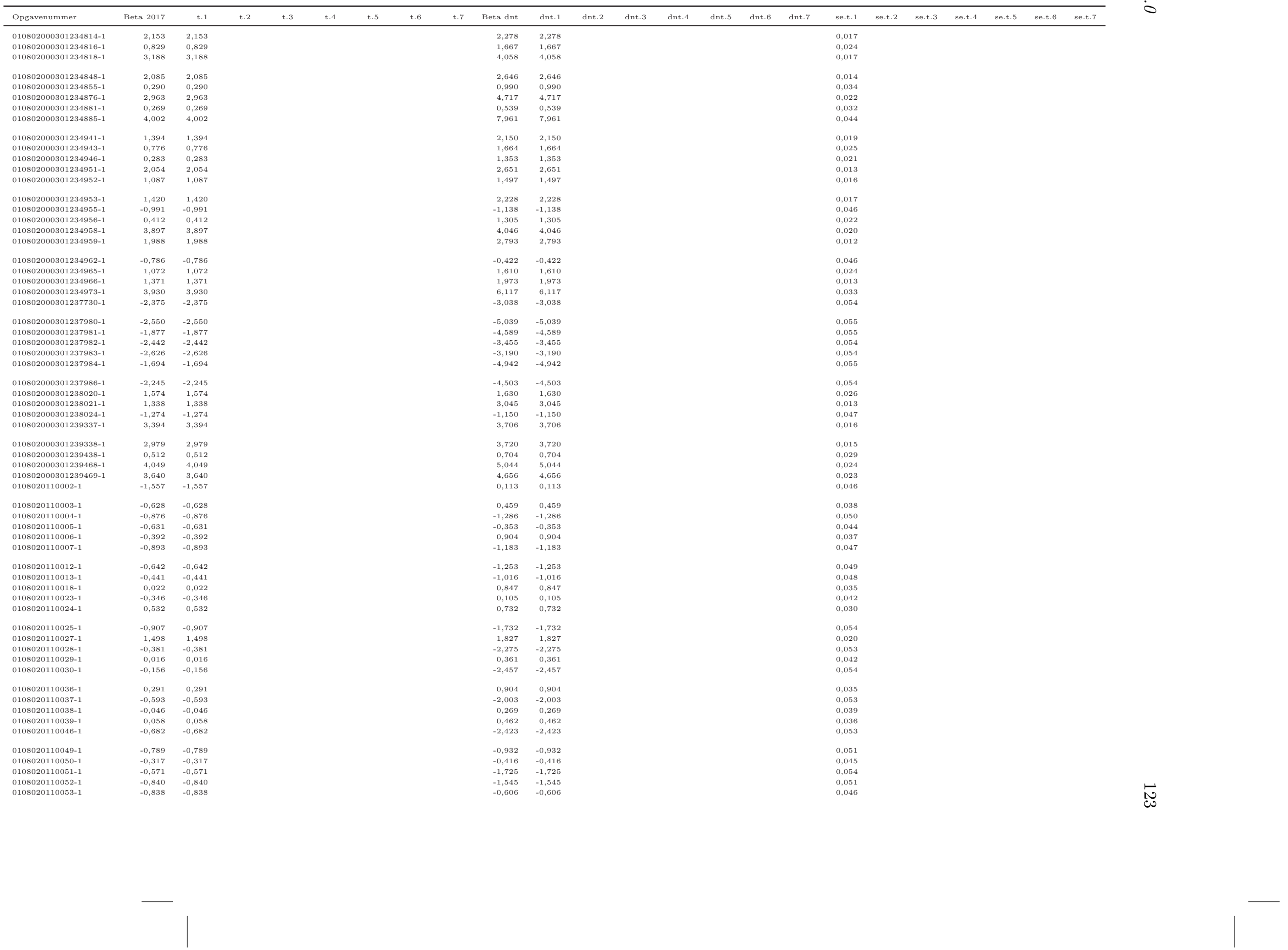


Tabel C.1: Item-parametre (continued)

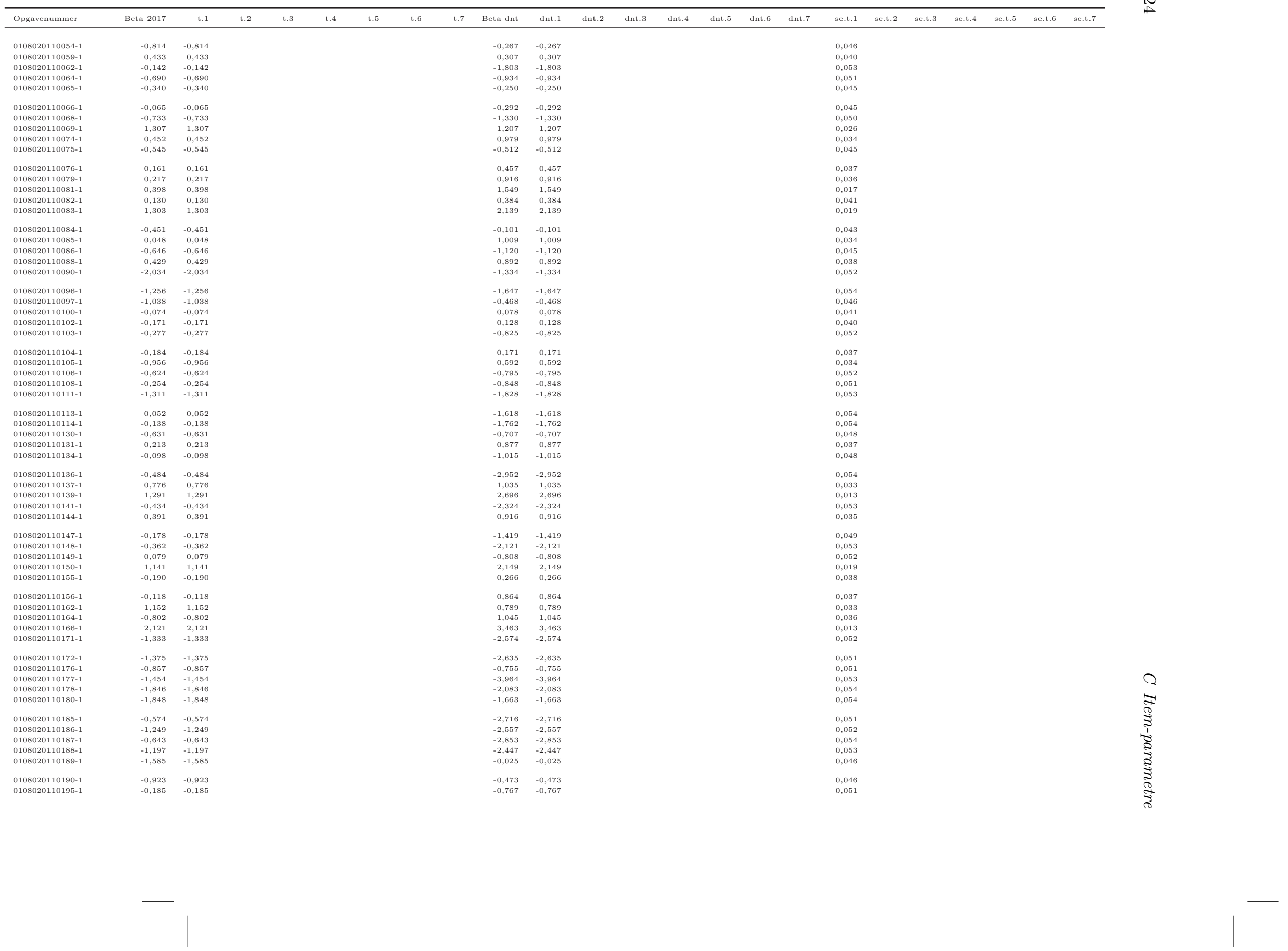


Tabel C.1: Item-parametre (continued)

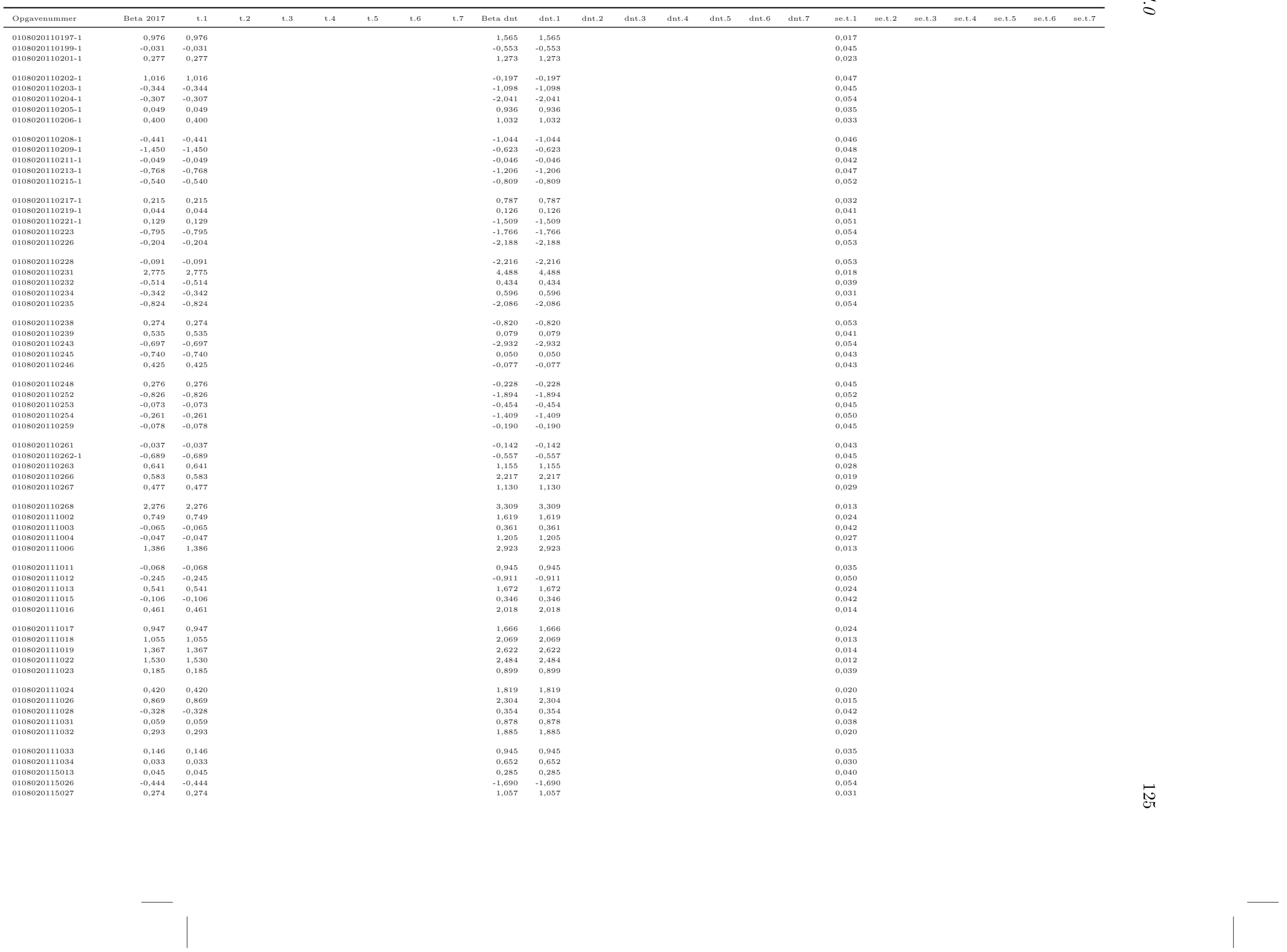


Tabel C.1: Item-parametre (continued)

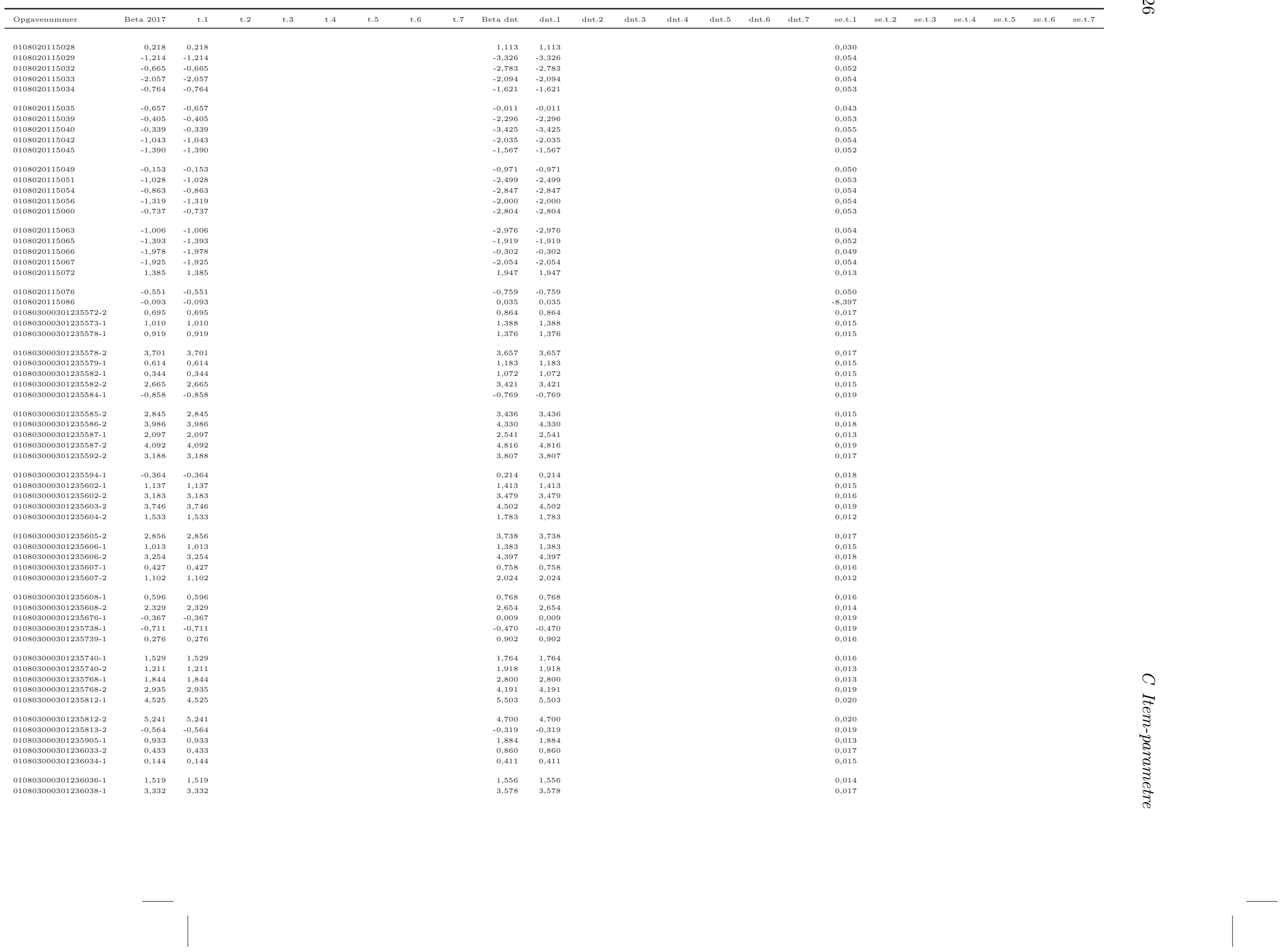


Tabel C.1: Item-parametre (continued)

\begin{tabular}{|c|c|c|c|c|c|c|c|c|c|c|c|c|c|c|c|c|c|c|c|c|c|c|c|}
\hline Opgavenummer & Beta 2017 & t.1 & t.2 & t. 3 & t. 4 & t. .5 & t. 6 & t. 7 & Beta dnt & dnt.1 & dnt.2 & dnt. 3 & $\mathrm{dnt} .4$ & dnt. 5 & dnt. 6 & dnt. 7 & se.t.1 & se.t.2 & se.t.3 & se.t.4 & se.t. 5 & se.t.6 & se.t.7 \\
\hline $\begin{array}{l}010803000301237450-3 \\
010803000301238301-1 \\
010803000301238303-1\end{array}$ & $\begin{array}{r}0,601 \\
-0,336 \\
-0,205\end{array}$ & $\begin{aligned} 0,601 \\
-0,036 \\
-0,205\end{aligned}$ & & & & & & & $\begin{array}{l}0,601 \\
0,014 \\
0,585\end{array}$ & $\begin{array}{l}0,601 \\
0,014 \\
0,585\end{array}$ & & & & & & & $\begin{array}{l}0,017 \\
0,019 \\
0,015\end{array}$ & & & & & & \\
\hline $\begin{array}{l}010803000301238387-1 \\
010080000301238346-1 \\
010803000301238347-1 \\
010803000301238348-1 \\
010803000301238349-1\end{array}$ & $\begin{array}{r}0,586 \\
-1,117 \\
0,240 \\
-1,239 \\
1,719\end{array}$ & $\begin{array}{r}0,586 \\
-1,117 \\
0,240 \\
-1,239 \\
1,719\end{array}$ & & & & & & & $\begin{array}{r}1,153 \\
-1,177 \\
0,130 \\
-0,549 \\
1,621\end{array}$ & $\begin{array}{r}1,153 \\
-1,177 \\
0,130 \\
-0,599 \\
1,621\end{array}$ & & & & & & & $\begin{array}{l}0,015 \\
0,019 \\
0,019 \\
0,019 \\
0,013\end{array}$ & & & & & & \\
\hline $\begin{array}{l}010803000301238350-1 \\
010803000301238567-1\end{array}$ & $\begin{array}{l}1,305 \\
0,484\end{array}$ & $\begin{array}{l}1,305 \\
0,484\end{array}$ & & & & & & & $\begin{array}{l}0,853 \\
0,342\end{array}$ & $\begin{array}{l}0,853 \\
0,342\end{array}$ & & & & & & & $\begin{array}{l}0,018 \\
0,017\end{array}$ & & & & & & \\
\hline $010803000301238568-1$ & $-0,015$ & 0,153 & $-2,021$ & $-3,127$ & $-4,058$ & $-3,448$ & $-3,092$ & $-0,107$ & 0,096 & $-0,406$ & $-0,818$ & $-0,728$ & $-0,289$ & 0,342 & 1,010 & 1,56 & 0,196 & 0,381 & 0,540 & 0,687 & 0,861 & 1,098 & 0,125 \\
\hline $010803000301238640-1$ & $-0,025$ & $\begin{array}{r}1,2024 \\
-1,486\end{array}$ & $-1,776$ & $-2,380$ & $-1,201$ & $-0,126$ & & & $\begin{array}{l}\begin{array}{l}1,29 \\
0,194\end{array} \\
0.04\end{array}$ & $\begin{array}{r}1,029 \\
-1,120\end{array}$ & $-0,715$ & 0,132 & 1,041 & 1,631 & & & $\begin{array}{l}0,121 \\
0,121\end{array}$ & 0,213 & 0,304 & 0,439 & 0,084 & & \\
\hline $010803000301238646-1$ & $-0,509$ & $-0,755$ & $-3,136$ & $-3,494$ & $-3,854$ & $-2,544$ & & & $-0,116$ & $-0,872$ & $-0,891$ & $-0,391$ & 0,384 & 1,192 & & & 0,192 & 0,368 & 0,521 & 0,691 & 0,094 & & \\
\hline $010803000301238707-1$ & $-0,063$ & $-0,957$ & $-2,317$ & $-2,435$ & $-2,309$ & $-0,316$ & & & 0,062 & $-0,660$ & $-0,677$ & $-0,089$ & 0,651 & 1,086 & & & 0,141 & 0,255 & 0,359 & 0,480 & 0,087 & & \\
\hline $010803000301238708-1$ & $\begin{array}{l}1,280 \\
0,073\end{array}$ & 1,280 & 1.975 & 1.773 & 1641 & 0.364 & & & 0,676 & 0,676 & & 0.10 & 0433 & 336 & & & 0,016 & 0.23 & & the & & & \\
\hline $\begin{array}{l}\begin{array}{l}010803000030120387828-1 \\
010803000301238729-1\end{array}\end{array}$ & $\begin{array}{l}-0,073 \\
-0,279\end{array}$ & $\begin{array}{l}-0,609 \\
0,532 \\
\text { ons }\end{array}$ & $\begin{array}{l}-1,975 \\
-2,139 \\
-139\end{array}$ & $\begin{array}{l}-1,773 \\
-3,007\end{array}$ & $\begin{array}{l}-1,641 \\
-4,199\end{array}$ & $\begin{array}{l}-0,364 \\
-3,938\end{array}$ & $-4,199$ & $-1,953$ & $\begin{array}{l}0,164 \\
0,009\end{array}$ & $\begin{array}{l}-0,47 \\
-0,286 \\
-0,25\end{array}$ & $\begin{array}{l}-0,369 \\
-0,727\end{array}$ & $\begin{array}{l}-0,0101 \\
-0,712\end{array}$ & $\begin{array}{c}0,433 \\
-0,373\end{array}$ & $\begin{array}{l}\begin{array}{l}1,316 \\
0,157\end{array} \\
0\end{array}$ & 0,745 & 1,26 & $\begin{array}{l}0,118 \\
0,218\end{array}$ & $\begin{array}{l}0,221 \\
0,428\end{array}$ & $\begin{array}{l}0,621 \\
0,602\end{array}$ & $\begin{array}{l}0,442 \\
0,761\end{array}$ & 0,925 & 1,118 & 0,126 \\
\hline $010803000301238768-1$ & $-0,388$ & $-0,789$ & $-2,529$ & $-2,979$ & $-3,060$ & $-1,939$ & & & $-0,089$ & $-0,660$ & $-0,792$ & $-0,143$ & 0,560 & 0,591 & & & 0,128 & 0,242 & 0,343 & 0,456 & 0,086 & & \\
\hline $010803000301238769-1$ & 0,613 & 0,613 & & & & & & & 0,100 & 0,100 & & & & & & & 0,019 & & & & & & \\
\hline $010803000301238838-1$ & 2,140 & 2,140 & & & & & & & 1,395 & 1,395 & & & & & & & 0,015 & & & & & & \\
\hline $010803000301238840-1$ & 1,595 & 1,595 & & & & & & & 0,851 & 0,851 & & & & & & & 0,018 & & & & & & \\
\hline $010803000301238841-1$ & 0,890 & 0,890 & & & & & & & 0,584 & 0,584 & & & & & & & 0,015 & & & & & & \\
\hline $010803000301238844-1$ & $-0,079$ & $-1,522$ & $-1,971$ & $-2,586$ & $-1,799$ & $-0,393$ & & & 0,164 & $-0,927$ & $-0,423$ & 0,058 & 0,645 & 1,467 & & & 0,130 & 0,229 & 0,323 & 0,443 & 0,085 & & \\
\hline $010803000301238854-1$ & $-0,443$ & $-1,032$ & $-3,000$ & $-4,301$ & $-3,612$ & $-2,214$ & & & 0,041 & $-1,065$ & $-1,408$ & $-0,189$ & 1,260 & 1,605 & & & 0,152 & 0,290 & 0,414 & 0,585 & 0,091 & & \\
\hline $\begin{array}{l}010803000301238855-1 \\
010803000301238868-1\end{array}$ & $\begin{array}{l}0,841 \\
1,448\end{array}$ & $\begin{array}{l}0,841 \\
1.48\end{array}$ & & & & & & & $\begin{array}{l}0,272 \\
0,91\end{array}$ & $\begin{array}{l}0,272 \\
0.931\end{array}$ & & & & & & & $\begin{array}{l}0,018 \\
0,016\end{array}$ & & & & & & \\
\hline $010803000301238871-1$ & $\begin{array}{l}1,448 \\
-0,251\end{array}$ & $\begin{array}{r}1,448 \\
-1,102\end{array}$ & $-2,798$ & $-2,972$ & $-3,212$ & $-1,253$ & & & $\begin{array}{l}-0,025 \\
-0,31 \\
-\end{array}$ & $\begin{array}{l}-0,531 \\
-0,537\end{array}$ & $-0,754$ & $-0,398$ & 0,331 & 1,233 & & & 0,204 & 0,376 & 0,530 & 0,704 & 0,094 & & \\
\hline 010803000301238874-1 & $-0,582$ & $-0,614$ & $-2,929$ & $-3,066$ & $-3,805$ & $-2,909$ & & & $-0,182$ & $-0,313$ & $-0,625$ & $-0,641$ & $-0,198$ & 0,867 & & & 0,174 & 0,338 & 0,489 & 0,653 & 0,093 & & \\
\hline $010803000301238875-1$ & $-0,250$ & 0,220 & $-2,138$ & $-2,885$ & $-4,015$ & $-3,657$ & $-2,724$ & $-1,749$ & 0,091 & $-0,590$ & $-0,870$ & $-0,646$ & $-0,118$ & 0,515 & 1,053 & 1,30 & 0,214 & 0,418 & 0,591 & 0,752 & 0,934 & 1,215 & 0,128 \\
\hline $010803000301238988-1$ & 1,557 & 1,557 & & & & & & & 0,805 & 0,805 & & & & & & & 0,016 & & & & & & \\
\hline $\begin{array}{l}010803000301238989-1 \\
01080300301238990-1\end{array}$ & $\begin{array}{r}0,221 \\
-0,324\end{array}$ & $\begin{array}{l}0,221 \\
0.281\end{array}$ & -2.532 & $-3,472$ & -3.502 & $-1,618$ & & & $\begin{array}{r}0,284 \\
-0.160\end{array}$ & $\begin{array}{r}0,284 \\
-0,291\end{array}$ & $-1,023$ & -0.804 & 0.058 & 1.259 & & & $\begin{array}{l}0,018 \\
0,138\end{array}$ & 0.270 & 0.381 & 0.504 & 0.088 & & \\
\hline $010803000301238992-1$ & $-0,240$ & 0,228 & $-1,971$ & $-3,104$ & $-4,218$ & $-4,314$ & $-3,840$ & $-1,679$ & $-0,043$ & 0,083 & $-0,506$ & $-0,766$ & $-0,697$ & $-0,301$ & 0,420 & 1,47 & 0,201 & 0,395 & 0,566 & 0,723 & 0,883 & 1,095 & 0,126 \\
\hline 010803000301239051-1 & $-0,261$ & $-0,876$ & $-1,897$ & $-2,854$ & $-1,579$ & $-1,307$ & & & $\begin{array}{r}-0,043 \\
0,085\end{array}$ & 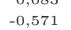 & $-0,900$ & $\begin{array}{l}-0,120 \\
-0,120 \\
-0.00\end{array}$ & $\begin{array}{l}-0,097 \\
0,865\end{array}$ & ${ }_{1,153}$ & & & 0,148 & 0,279 & 0,403 & 0,597 & 0,090 & & \\
\hline $010803000301239061-1$ & $-0,155$ & $\begin{array}{l}-0,485 \\
-0,10\end{array}$ & $-2,591$ & $-3,113$ & $-3,514$ & $-0,777$ & & & $-0,013$ & $-0,245$ & $-0,872$ & $\begin{array}{l}-0,933 \\
-0,103\end{array}$ & $-0,074$ & 2,058 & & & 0,147 & 0,280 & 0,396 & 0,520 & 0,089 & & \\
\hline $010803000301239062-1$ & $-0,276$ & 0,275 & $-2,490$ & $-2,689$ & $-2,606$ & $-1,381$ & & & $-0,258$ & $-0,326$ & $-0,930$ & $-0,546$ & 0,127 & 0,385 & & & 0,177 & 0,346 & 0,499 & 0,687 & 0,093 & & \\
\hline $010803000301239063-1$ & 0,356 & $-1,963$ & $-1,983$ & $-2,320$ & $-0,367$ & 1,779 & & & 0,207 & $-1,676$ & $-0,687$ & 0,239 & 1,133 & 2,026 & & & 0,115 & 0,185 & 0,251 & 0,357 & 0,077 & & \\
\hline 010803000301241375-1 & $-0,334$ & 0,268 & $-1,569$ & $-1,667$ & $-1,981$ & $-1,670$ & & & 0,155 & $-0,008$ & $-0,109$ & 0,076 & 0,340 & 0,477 & & & 0,102 & 0,201 & 0,298 & 0,407 & 0,083 & & \\
\hline 01241378-1 & $-0,405$ & $-1,074$ & $-1,658$ & $-2,694$ & $-2,899$ & $-2,024$ & & & 0,187 & $-0,825$ & $-0,346$ & 0,326 & 0,859 & 0,920 & & & 0,064 & 0,124 & 0,181 & 0,239 & 0,069 & & \\
\hline $010803000301241381-1$ & $-0,414$ & $-1,694$ & $-2,412$ & $-3,356$ & $-2,961$ & $-2,068$ & & & 0,054 & $-0,570$ & $-0,446$ & 0,073 & 0,573 & 0,642 & & & 0,124 & 0,228 & 0,324 & 0,434 & 0,086 & & \\
\hline 010803000301241383-1 & $-0,290$ & $-1,607$ & $-1,920$ & $-2,584$ & $-2,583$ & $-1,449$ & & & 0,242 & $-0,615$ & 0,371 & 0,473 & 0,344 & 0,638 & & & 0,063 & 0,118 & 0,170 & 0,225 & 0,064 & & \\
\hline $010803000301241389-1$ & $-0,259$ & $-0,984$ & $-2,328$ & $-3,306$ & $-2,956$ & $-1,295$ & & & 0,010 & $-0,634$ & $-0,907$ & $-0,207$ & 0,710 & 1,089 & & & 0,183 & 0,339 & 0,478 & 0,641 & 0,092 & & \\
\hline $\begin{array}{l}010803000301241390-1 \\
01080000030124399-1\end{array}$ & $\begin{array}{l}-0,266 \\
-0,008\end{array}$ & $\begin{array}{l}-0,266 \\
-0,08\end{array}$ & & & & & & & $\begin{array}{r}0,573 \\
-0,55\end{array}$ & $\begin{array}{r}0,573 \\
-0,500\end{array}$ & & & & & & & $\begin{array}{l}0,015 \\
0,019\end{array}$ & & & & & & \\
\hline $010803000301241409-1$ & $-0,246$ & $-0,578$ & $-2,659$ & $-2,844$ & $-3,064$ & $-1,231$ & & & 0,259 & $-0,778$ & $-0,205$ & 0,197 & 0,661 & 1,422 & & & 0,129 & 0,245 & 0,338 & 0,432 & 0,086 & & \\
\hline $010803000301241410-1$ & $-0,332$ & $-0,356$ & $-2,501$ & $-2,399$ & $-2,557$ & $-1,661$ & & & $-0,047$ & $-0,662$ & $-0,586$ & $-0,099$ & 0,440 & 0,672 & & & 0,120 & 0,231 & 0,330 & 0,445 & 0,086 & & \\
\hline $010803000301241412-1$ & $-0,803$ & $-0,734$ & $-2,002$ & $-3,530$ & $-3,519$ & $-4,017$ & & & $-0,220$ & 0,356 & $-0,800$ & $-0,402$ & 0,178 & $-0,431$ & & & 0,118 & 0,233 & 0,346 & 0,481 & 0,088 & & \\
\hline 010803000301241413-1 & $-0,221$ & $-0,842$ & $-2,713$ & $-2,611$ & $-2,955$ & $-1,104$ & & & 0,218 & $-0,717$ & $-0,231$ & 0,144 & 0,594 & 1,300 & & & 0,132 & 0,247 & 0,341 & 0,439 & 0,086 & & \\
\hline 010803000301241414-1 & & $-0,280$ & $-2,312$ & $-2,705$ & $-3,155$ & $-2,742$ & & & $-0,147$ & $-0,002$ & $-0,359$ & $-0,136$ & 0,075 & $-0,313$ & & & 0,111 & 0,216 & 15 & 0,424 & 0,085 & & \\
\hline $010803000301241415-1$ & $-0,341$ & $-1,371$ & $-1,986$ & $-3,242$ & $-2,376$ & $-1,707$ & & & 0,107 & $-0,612$ & $-0,430$ & 0,110 & 0,646 & 0,819 & & & 0,122 & 0,227 & 0,324 & 0,442 & 0,086 & & \\
\hline $\begin{array}{l}01080300003012124593-1 \\
010803000301241597-1\end{array}$ & $\begin{array}{l}-0,464 \\
-0,167\end{array}$ & $\begin{array}{l}-0,999 \\
-0,096\end{array}$ & $\begin{array}{l}-2,487 \\
-2,230\end{array}$ & $\begin{array}{l}-3,640 \\
-2,217\end{array}$ & $\begin{array}{l}-3,029 \\
-2,251\end{array}$ & $\begin{array}{l}-2,319 \\
-0,837\end{array}$ & & & - $\begin{array}{c}-0,065 \\
0,213\end{array}$ & $\begin{array}{l}-0,569 \\
-0,616\end{array}$ & $\begin{array}{l}-0,743 \\
-0,463\end{array}$ & 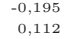 & $\begin{array}{l}0,482 \\
0,788\end{array}$ & $\begin{array}{l}0,699 \\
1,244\end{array}$ & & & o, 0,127 & $\begin{array}{l}0,240 \\
0,230\end{array}$ & $\begin{array}{l}0,340 \\
0,326\end{array}$ & $\begin{array}{l}0,462 \\
0,434\end{array}$ & $\begin{array}{l}0,087 \\
0,085\end{array}$ & & \\
\hline 010803000301241806-1 & $-0,295$ & $-1,460$ & $-2,163$ & $-2,011$ & $-1,180$ & & & & 0,025 & $-0,953$ & $-0,270$ & 0,313 & 1,010 & & & & 0,106 & 0,198 & 0,300 & 0.070 & & & \\
\hline & & & $-1,808$ & $-2,707$ & $-2,550$ & $-0,855$ & & & & & & & 0,034 & 0,935 & & & & & & 0,440 & 0,085 & & \\
\hline $010803000301241808-1$ & $-0,315$ & $-0,487$ & $-1,849$ & $-2,074$ & $-2,255$ & $-1,573$ & & & $-0,004$ & $-0,563$ & $-0,1$ & $-0,025$ & 0,110 & 0,597 & & & 0,098 & 0,189 & 0,277 & 0,376 & 0,080 & & \\
\hline $010803000301241811-1$ & $-0,634$ & $-0,475$ & $-1,659$ & $-2,375$ & $-2,927$ & $-3,168$ & & & 0,034 & 0,053 & 0,186 & $-0,221$ & $-0,373$ & 0,523 & & & 0,094 & 0,185 & 0,277 & 0,379 & 0,081 & & \\
\hline $010803000301241812-1$ & 0,077 & $-1,845$ & $-2,350$ & $-3,518$ & $-2,694$ & 0,388 & & & 0,124 & $-1,310$ & $-0,854$ & $-0,082$ & 0,896 & 1,971 & & & 0,233 & 0,400 & 0,554 & 0,749 & 0,094 & & \\
\hline $010803000301241917-1$ & $-0,365$ & $-0,592$ & $-1,737$ & $-2,360$ & $-2,326$ & $-1,827$ & & & 0,132 & $-0,033$ & $-0,278$ & 0,052 & 0,462 & 0,459 & & & 0,105 & 0,203 & 0,297 & 0,404 & 0,0 & & \\
\hline $010803000301241921-1$ & $-0,451$ & $-0,717$ & $-2,357$ & $-3,387$ & $-2,725$ & $-2,256$ & & & $-0,019$ & $-0,247$ & $-0,602$ & $-0,350$ & 0,233 & 0,872 & & & & 0,252 & 0,360 & 0,498 & 0,088 & & \\
\hline $\begin{array}{l}803000301241924-1 \\
030300301221952-1\end{array}$ & $-0,371$ & $\begin{array}{l}-0,596 \\
-0512\end{array}$ & $-2,245$ & $\begin{array}{l}-2,222 \\
-2,499\end{array}$ & $-2,314$ & $\begin{array}{l}-1,854 \\
-2,79\end{array}$ & & & $\begin{array}{r}0,008 \\
-0,176\end{array}$ & - $-0,469$ & $-0,495$ & $\begin{array}{l}0,054 \\
-0,857\end{array}$ & $\begin{array}{r}0,558 \\
0.49\end{array}-2$ & 0,395 & & & 0,108 & 0,208 & $0,0,304$ & 0,415 & 0,084 & & \\
\hline $\begin{array}{l}01080300030001241925-1 \\
0108000\end{array}$ & $\begin{array}{r}-0,558 \\
0,272\end{array}$ & $\begin{array}{l}-0,512 \\
-1,086\end{array}$ & $\begin{array}{l}-1,983 \\
-1,464\end{array}$ & $\begin{array}{l}-2,499 \\
-1,158\end{array}$ & $\begin{array}{l}-3,538 \\
-0,250\end{array}$ & $\begin{array}{l}-2,789 \\
1,359\end{array}$ & & & $\begin{array}{l}-0,176 \\
0,324\end{array}$ & $\begin{array}{r}0,477 \\
-0,945\end{array}$ & $\begin{array}{r}-0,534 \\
0,172\end{array}$ & $\begin{array}{l}-0,857 \\
0,707\end{array}$ & $\begin{array}{l}-0,499 \\
0,859\end{array}$ & $\begin{array}{l}0,033 \\
0,826\end{array}$ & & & $\begin{array}{l}0,062 \\
0,067\end{array}$ & $\begin{array}{l}0,317 \\
0,122\end{array}$ & $\begin{array}{l}0,468 \\
0,173\end{array}$ & $\begin{array}{l}0,626 \\
0,235\end{array}$ & $\begin{array}{l}0,092 \\
0,063\end{array}$ & & \\
\hline
\end{tabular}


Tabel C.1: Item-parametre (continued)

\begin{tabular}{|c|c|c|c|c|c|c|c|c|c|c|c|c|c|c|c|c|c|c|c|c|c|c|c|}
\hline Opgavenummer & Beta 2017 & t. 1 & t. 2 & t. 3 & $\mathrm{t} .4$ & t.5 & t. 6 & $\mathrm{t} .7$ & Beta dnt & dnt.1 & dnt.2 & dnt. 3 & $\mathrm{dnt} .4$ & $\mathrm{dnt.5}$ & dnt. 6 & dnt. 7 & se.t.1 & se.t.2 & se.t. 3 & se.t.4 & se.t. 5 & se.t. 6 & se.t. 7 \\
\hline $010803000301242169-1$ & $-0,142$ & -0.629 & -1.874 & -2.564 & -2.622 & -2.074 & -0.852 & & 0.044 & $-0,367$ & -0.700 & -0.404 & 0.179 & 0.710 & 0.847 & & 0.129 & 0.241 & 0.342 & 0.447 & 0.588 & 0.099 & \\
\hline $010803000301242171-1$ & $-0,627$ & $-1,215$ & $-2,593$ & $-3,866$ & $-3,659$ & $-3,133$ & & & $-0,079$ & $-0,308$ & $-0,637$ & $-0,174$ & 0,384 & 0,338 & & & 0,126 & 0,241 & 0,344 & 0,461 & 0,088 & & \\
\hline $010803000301242180-1$ & 0,103 & $-0,658$ & $-1,521$ & $-2,354$ & $-2,844$ & 0,515 & & & 0,358 & 0,601 & $-0,514$ & $-1,287$ & $-0,415$ & 3,404 & & & 0,166 & 0,318 & 0,465 & 0,617 & 0,091 & & \\
\hline 010803000301242204-1 & $-0,196$ & $-0,845$ & $-2,636$ & $-2,647$ & $-2,364$ & $-0,979$ & & & $-0,006$ & $-0,880$ & $-0,676$ & 0,097 & 0,767 & 0,663 & & & 0,131 & 0,244 & 0,339 & 0,449 & 0,086 & & \\
\hline 010803000301242207-1 & $-0,687$ & $-0,431$ & $-1,144$ & $-1,569$ & $-2,962$ & $-3,434$ & & & $-0,237$ & 1,151 & 0,057 & $-0,524$ & $-0,818$ & $-1,053$ & & & 0,109 & 0,219 & 0,333 & 0,455 & 0,084 & & \\
\hline $010803000301242228-1$ & $-0,410$ & $-0,477$ & $-3,306$ & $-3,662$ & $-3,758$ & $-2,049$ & & & $-0,015$ & $-0,980$ & $-0,932$ & $-0,150$ & 0,767 & 1,221 & & & 0,200 & 0,382 & 0,521 & 0,675 & 0,093 & & \\
\hline $010803000301242234-1$ & $-0,547$ & $-1,374$ & $-2,124$ & $-3,298$ & $-2,985$ & $-2,735$ & & & $-0,147$ & 0,042 & $-0,599$ & $-0,541$ & $-0,090$ & 0,453 & & & 0,149 & 0,284 & 0,415 & 0,576 & 0,091 & & \\
\hline 010803000301242250-1 & $-0,131$ & $-0,673$ & $-2,158$ & $-2,186$ & $-2,649$ & $-0,657$ & & & 0,258 & $-0,382$ & $-0,241$ & $-0,150$ & 0,349 & 1,713 & & & 0,128 & 0,239 & 0,336 & 0,440 & 0,085 & & \\
\hline $\begin{array}{l}\begin{array}{l}01800300030012422544-1 \\
010803000301242264-1\end{array}\end{array}$ & $\begin{array}{l}0,157 \\
0,005\end{array}$ & $\begin{array}{l}-0,680 \\
-1,096 \\
-109\end{array}$ & $\begin{array}{l}-1,297 \\
-1,779\end{array}$ & $\begin{array}{l}-1,375 \\
-1873\end{array}$ & $\begin{array}{l}-1,245 \\
-1,476\end{array}$ & $\begin{array}{l}-0,472 \\
0.024\end{array}$ & 0,942 & & 0,178 & $\begin{array}{l}-0,427 \\
-0349\end{array}$ & $-0,063$ & ${ }^{0,132}$ & 0,261 & 0,428 & 0,735 & & 0,114 & 0,212 & 0,303 & 0,400 & 0,526 & 0,094 & \\
\hline & & & & & & & & & & & & & & & & & & & & $0,0,990$ & ,0,082 & & \\
\hline $\begin{array}{l}01080300030124269-1 \\
010803000301242272-1\end{array}$ & $\begin{array}{r}-0,197 \\
0,036\end{array}$ & $\begin{array}{l}-0,802 \\
-0,341\end{array}$ & $\begin{array}{l}-1,641 \\
-2,870\end{array}$ & $\begin{array}{l}-2,561 \\
-2,888 \\
-\end{array}$ & $\begin{array}{l}-3,131 \\
-2,488 \\
-2.03\end{array}$ & $\begin{array}{l}-2,872 \\
0.183\end{array}$ & $-1,184$ & & $\left.\begin{array}{c}-0,049 \\
0.083\end{array}\right] \mathrm{C}$ & $\begin{array}{r}0,166 \\
-1,351\end{array}$ & $\begin{array}{l}-0,406 \\
-1,000\end{array}$ & $\begin{array}{r}-0,690 \\
-0,009\end{array}$ & $\begin{array}{r}-0,584 \\
1,075\end{array}$ & $\begin{array}{l}0,014 \\
1,702\end{array}$ & 1,204 & & 0,186 & 0,354 & 0,514 & 0,674 & 0,872 & 0,109 & \\
\hline $\begin{array}{l}\begin{array}{l}0108030003012427272-1 \\
010803000301242274-1\end{array}\end{array}$ & $\begin{array}{r}0,036 \\
-0,851\end{array}$ & $\begin{array}{l}-0,341 \\
-0,816\end{array}$ & $\begin{array}{l}-2,870 \\
-1,995\end{array}$ & $\begin{array}{l}-2,888 \\
-3,884\end{array}$ & $\begin{array}{l}-2,488 \\
-3,618 \\
-318\end{array}$ & $\begin{array}{r}0,183 \\
-4,257\end{array}$ & & & $\begin{array}{l}0,0833 \\
-0,235\end{array}$ & $\begin{array}{r}-1,351 \\
0,390\end{array}$ & $\begin{array}{l}-1,000 \\
-0,599\end{array}$ & $\begin{array}{l}\begin{array}{r}-0,009 \\
-0,880\end{array} \\
-\end{array}$ & $\begin{array}{r}1,075 \\
-0,516\end{array}$ & $\begin{array}{l}1,702 \\
0,430\end{array}$ & & & $\begin{array}{l}0,213 \\
0,46\end{array}$ & $\begin{array}{l}0,423 \\
0,290\end{array}$ & $\begin{array}{l}0,560 \\
0.431\end{array}$ & $\begin{array}{l}0,761 \\
0.612\end{array}$ & 0,094 & & \\
\hline $010803000301242310-1$ & $\begin{array}{l}-0,001 \\
-0.477\end{array}$ & $\begin{array}{l}-0,810 \\
-0,124\end{array}$ & $\begin{array}{l}-1,950 \\
-2,479\end{array}$ & $\begin{array}{l}-3,884 \\
-2,828\end{array}$ & $\begin{array}{l}-3,018 \\
-3,631\end{array}$ & $\begin{array}{l}-4,297 \\
-2,385\end{array}$ & & & $\begin{array}{l}-0,230 \\
-0,021\end{array}$ & $\begin{array}{r}0,019 \\
-0,019\end{array}$ & $\begin{array}{l}-0,097 \\
-0,507\end{array}$ & $\begin{array}{l}-0,080 \\
-0,493\end{array}$ & $\begin{array}{l}-0,010 \\
-0,007\end{array}$ & $\begin{array}{l}0,400 \\
0,923\end{array}$ & & & 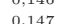 & 年, & ons & 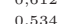 & $\begin{array}{l}0,092 \\
0,090\end{array}$ & & \\
\hline $010803000301242313-1$ & $-0,444$ & $-1,079$ & $\begin{array}{l}-1,896 \\
-2,496\end{array}$ & $-3,190$ & $\begin{array}{l}-3,362 \\
-3,302\end{array}$ & $-2,222$ & & & $-0,211$ & 0,306 & $-0,340$ & $\begin{array}{l}-0,910 \\
-0,910\end{array}$ & $-0,781$ & 0,668 & & & 0,166 & 0,319 & 0.467 & $\begin{array}{l}0,634 \\
0,632\end{array}$ & 0,0900 & & \\
\hline 1010803000301242315-1 & $-0,252$ & $-0,910$ & $-2,339$ & $-2,992$ & $-3,497$ & $-3,069$ & -1.513 & & 0,044 & 0,022 & -0.396 & $-0,517$ & $-0,310$ & 0.255 & 1,208 & & 0,169 & 0.314 & 0.441 & $0.566-250$ & 0.722 & 0.106 & \\
\hline $010803000301242596-1$ & $-0,139$ & $-1,300$ & $-2,178$ & $\begin{array}{l}-2,619 \\
-2,19\end{array}$ & $-2,424$ & $-0,696$ & & & $\begin{array}{l}-0,044 \\
-0,025\end{array}$ & $\begin{array}{r}0,022 \\
-0,230\end{array}$ & $\begin{array}{l}-0,396 \\
-0,559\end{array}$ & $\begin{array}{l}-0,017 \\
-0,570\end{array}$ & $\begin{array}{l}-0,0,030 \\
-0,035\end{array}$ & $\begin{array}{l}0,253 \\
1,269\end{array}$ & 1,208 & & $\begin{array}{l}0,169 \\
0,188\end{array}$ & 0,344 & $\begin{array}{l}0,441 \\
0,496\end{array}$ & $\begin{array}{l}0,006 \\
0,682\end{array}$ & $\begin{array}{l}0,722 \\
0,093\end{array}$ & 0,106 & \\
\hline $010803000301242597-1$ & $-0,778$ & $-0,486$ & $-1,775$ & $-2,268$ & $-3,746$ & $-3,890$ & & & $\begin{array}{l}-0,250 \\
-0,250\end{array}$ & 1,120 & 0,119 & $-0,710$ & $-1,078$ & $\begin{array}{r}-0,699 \\
-1,299 \\
-10\end{array}$ & & & 0,126 & $\begin{array}{l}0,250 \\
0,250\end{array}$ & 0,375 & 0,506 & 0,089 & & \\
\hline 010803000301242601-1 & $-0,571$ & $-1,712$ & $-2,612$ & $-3,792$ & $-3,986$ & $-2,855$ & & & $-0,101$ & 0,113 & $-0,690$ & $-0,659$ & $-0,070$ & 0,802 & & & 0,189 & 0,351 & 0,502 & 0,667 & 0,093 & & \\
\hline 010803000301242603-1 & $-0,164$ & $-1,171$ & $-1,699$ & $-2,057$ & $-1,704$ & $-0,818$ & & & 0,070 & $-0,448$ & $-0,399$ & 0,099 & 0,568 & 0,530 & & & 0,114 & 0,213 & 0,308 & 0,423 & 0,084 & & \\
\hline 010803000301242744-1 & $-0,797$ & $-0,754$ & $-2,110$ & $-3,666$ & $-3,838$ & $-3,985$ & & & $-0,271$ & 0,619 & $-0,432$ & $-0,649$ & $-0,489$ & $-0,405$ & & & 0,141 & 0,278 & 0,410 & 0,561 & 0,091 & & \\
\hline $010803000301243169-1$ & $-0,406$ & $-0,268$ & $-1,647$ & $-3,369$ & $-2,820$ & $-2,030$ & & & 0,016 & $-0,440$ & $-0,826$ & $-0,482$ & 0,360 & 1,471 & & & 0,172 & 0,335 & 0,488 & 0,673 & 0,093 & & \\
\hline 01080303060910301-3 & $-0,928$ & $-0,531$ & $-1,883$ & $-2,985$ & $-3,713$ & & & & $-0,814$ & $-0,458$ & $-0,654$ & $-1,372$ & $-0,772$ & & & & 0,106 & 0,216 & 0,340 & 0,070 & & & \\
\hline $\begin{array}{l}01080303060910317 \\
01080303060910322\end{array}$ & $\begin{array}{r}-0,345 \\
0,210\end{array}$ & $\begin{array}{r}-0,345 \\
0,210\end{array}$ & & & & & & & $\begin{array}{r}-0,288 \\
0,051\end{array}$ & $\begin{array}{r}-0,288 \\
0,051\end{array}$ & & & & & & & $\begin{array}{l}0,019 \\
0,019\end{array}$ & & & & & & \\
\hline 01080303060910323 & $-0,444$ & $-0,444$ & & & & & & & $-0,417$ & $-0,417$ & & & & & & & 0,019 & & & & & & \\
\hline 01080303060910325 & $-0,836$ & $-0,821$ & $\begin{array}{l}-1,636 \\
-1872\end{array}$ & $-2,509$ & & & & & $-0,910$ & $\begin{array}{r}-1,316 \\
-0058\end{array}$ & $-0,974$ & $-0,439$ & & & & & 0,111 & 0,244 & 0,055 & & & & \\
\hline 01080303060910327 & $-0,660$ & $-0,927$ & $-1,872$ & $-2,617$ & $-2,641$ & & & & $-0,549$ & $-0,958$ & $-0,841$ & $-0,607$ & 0,211 & & & & 0,103 & 0,207 & 0,322 & 0,070 & & & \\
\hline $\begin{array}{l}01080303060940009-1 \\
01080303060940011-1\end{array}$ & $\begin{array}{r}0,494 \\
-1,028\end{array}$ & $\begin{array}{l}-1,174 \\
-1,028\end{array}$ & $-0,333$ & ${ }^{1,483}$ & & & & & $\begin{array}{r}0,235 \\
-1,603\end{array}$ & $\begin{array}{r}-1,250 \\
-1,603\end{array}$ & 0,630 & 1,323 & & & & & $\begin{array}{l}0,058 \\
0,019\end{array}$ & 0,113 & 0,045 & & & & \\
\hline 0108030310005-7 & 0,865 & 0,865 & & & & & & & $-0,757$ & $-0,757$ & & & & & & & 0,019 & & & & & & \\
\hline 0108030310006-3 & 0,100 & 0,100 & & & & & & & 0,898 & 0,898 & & & & & & & 0,017 & & & & & & \\
\hline 0108030310009-2 & 0,683 & 0,683 & & & & & & & 1,199 & ${ }^{1,199}$ & & & & & & & 0,015 & & & & & & \\
\hline $0108030310011-1$ & $-0,616$ & $-1,513$ & $-2,121$ & $-3,453$ & $-2,465$ & & & & $-0,285$ & $-1,083$ & $-0,179$ & $-0,889$ & 1,011 & & & & 0,149 & 0,287 & 0,427 & 0,075 & & & \\
\hline 0108030310015-2 & $-0,567$ & $-1,573$ & $-2,289$ & $-1,699$ & & & & & $-0,071$ & $-0,399$ & $-0,530$ & 0,715 & & & & & 0,115 & 0,225 & 0,056 & & & & \\
\hline 0108030310016-2 & $-0,654$ & $-1,139$ & $-2,122$ & $-1,962$ & & & & & $-0,358$ & $-0,730$ & $-0,455$ & 0,112 & & & & & 0,144 & 0,291 & 0,057 & & & & \\
\hline $0108030310017-2$ & $-0,790$ & $-1,345$ & $-2,392$ & $-2,369$ & & & & & 0,025 & 0,154 & $-0,543$ & 0,465 & & & & & 0,098 & 0,197 & 0,055 & & & & \\
\hline 0108030310018-2 & 0,499 & $\begin{array}{l}0,499 \\
-1039\end{array}$ & & & & & & & 0,688 & 0,688 & & & & & & & 0,016 & & & & & & \\
\hline $\begin{array}{l}\begin{array}{l}0108030310020-2 \\
0108030310024-3\end{array} \\
010\end{array}$ & $\begin{array}{l}-0,039 \\
-1,548\end{array}$ & $\begin{array}{l}-0,039 \\
-1,548\end{array}$ & & & & & & & $\begin{array}{l}-0,857 \\
-1,728\end{array}$ & $\begin{array}{l}-0,857 \\
-1,728\end{array}$ & & & & & & & $\begin{array}{l}0,019 \\
0,018\end{array}$ & & & & & & \\
\hline 0108030310372 & 0,821 & 0,821 & & & & & & & $\begin{array}{r}1,561 \\
2,062\end{array}$ & 1,561 & & & & & & & 0,013 & & & & & & \\
\hline $\begin{array}{l}\text { O108030310373 } \\
0108030310606-1\end{array}$ & $\begin{array}{l}-1,048 \\
-0,539\end{array}$ & $\begin{array}{l}-0,886 \\
-0,539\end{array}$ & $-1,967$ & $-3,262$ & $-4,191$ & & & & $\begin{aligned}-2,062 \\
0,507\end{aligned}$ & $\begin{array}{r}-2,277 \\
0,507\end{array}$ & $-1,662$ & $-2,047$ & $-2,261$ & & & & $\begin{array}{l}0,075 \\
0,015\end{array}$ & 0,156 & 0,252 & 0,062 & & & \\
\hline $\begin{array}{l}0108030310609-1 \\
0108030310611-2\end{array}$ & $\begin{array}{r}1,015 \\
-0,759\end{array}$ & $\begin{array}{r}1,015 \\
-0,730\end{array}$ & $-1,604$ & $-2,812$ & $-3,803$ & $-3,795$ & & & $\begin{array}{l}-0,796 \\
-0,343\end{array}$ & $\begin{array}{r}-0,796 \\
0,106\end{array}$ & $-1,004$ & $-0,994$ & $-0,333$ & 0,509 & & & $\begin{array}{l}0,020 \\
0,104\end{array}$ & 0,208 & 0,312 & 0,425 & 0,085 & & \\
\hline - & -0.480 & 0480 & & & & & & & 0.783 & 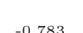 & & & & & & & 0.019 & & & & & & \\
\hline $\begin{array}{l}\begin{array}{l}0108030310012-1 \\
0180030313613-2\end{array} \\
01003\end{array}$ & $\begin{array}{l}-0,480 \\
-0,209\end{array}$ & $\begin{array}{l}-0,480 \\
-1,230\end{array}$ & -2088 & -2.505 & $-0,836$ & & & & $\begin{array}{l}-0,783 \\
-0.304\end{array}$ & $\begin{array}{l}-0,783 \\
-1,195\end{array}$ & -1.364 & 0.008 & 1.334 & & & & $\begin{array}{l}0,019 \\
0,114\end{array}$ & 0.223 & 0.347 & 0.072 & & & \\
\hline 0108030311006 & $-0,859$ & $-0,859$ & & & & & & & $-1,600$ & $-1,600$ & & & & & & & 0,019 & & & & & & \\
\hline 0108030311017 & $-0,148$ & $-0,148$ & & & & & & & $-1,232$ & $-1,232$ & & & & & & & 0,019 & & & & & & \\
\hline 0108030311018 & 0,190 & 0,190 & & & & & & & 0,182 & 0,182 & & & & & & & 0,018 & & & & & & \\
\hline 0108030311020 & $-0,060$ & $-0,060$ & & & & & & & $\begin{array}{l}-1,133 \\
-0.911\end{array}$ & $\begin{array}{l}-1,133 \\
-0.13\end{array}$ & & & & & & & $\begin{array}{l}0,019 \\
0019\end{array}$ & & & & & & \\
\hline 0108030311028 & $\begin{array}{r}-0,9 \\
0,0\end{array}$ & $\begin{array}{l}-0,989 \\
-1214\end{array}$ & -1.284 & 0.029 & & & & & $\begin{array}{l}-0,911 \\
0.165\end{array}$ & $\begin{array}{l}-0,911 \\
-0,617\end{array}$ & 0.269 & 0.843 & & & & & $\begin{array}{l}0,019 \\
0,086\end{array}$ & & 0.052 & & & & \\
\hline $\begin{array}{l}010800030311030 \\
0108030320002\end{array}$ & $\begin{array}{r}0,01010 \\
-0.520\end{array}$ & $\begin{array}{l}-1,214 \\
-1,210\end{array}$ & $\begin{array}{l}-1,284 \\
-1,620\end{array}$ & $\begin{array}{l}0,029 \\
-1,561\end{array}$ & & & & & $\begin{array}{l}0,165 \\
-0,045\end{array}$ & $\begin{array}{l}-0,617 \\
-0,420\end{array}$ & $\begin{array}{l}0,2699 \\
-0,317\end{array}$ & 0,600 & & & & & $\begin{array}{l}0,086 \\
0,101\end{array}$ & $\begin{array}{l}0,166 \\
0,207\end{array}$ & 0.054 & & & & \\
\hline $\begin{array}{l}10803030320022 \\
0108030320015\end{array}$ & $\begin{array}{r}-0,520 \\
0,289\end{array}$ & $\begin{array}{r}-1,210 \\
0,289\end{array}$ & & & & & & & $\begin{aligned}-0,045 \\
0,103 \\
0\end{aligned}$ & $\begin{array}{r}-0,420 \\
0,103\end{array}$ & & & & & & & $\begin{array}{l}0,101 \\
0,019\end{array}$ & & & & & & \\
\hline 0108030320016 & $-0,494$ & $-1,100$ & $-1,836$ & $-1,482$ & & & & & $-0,769$ & $-1,229$ & $-0,980$ & $-0,099$ & & & & & 0,108 & 0,226 & 0,055 & & & & \\
\hline $\begin{array}{l}101080303200019-2 \\
0108030320020-2\end{array}$ & $\begin{array}{l}-0,060 \\
0,545\end{array}$ & $\begin{array}{l}-0,850 \\
-0,894\end{array}$ & $\begin{array}{l}-1,245 \\
-0,793\end{array}$ & 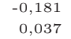 & 2,178 & & & & $\begin{array}{l}-0,164 \\
1,023\end{array}$ & $\begin{array}{l}-1,130 \\
-0,422\end{array}$ & $\begin{array}{l}-0,290 \\
0,584\end{array}$ & $\begin{array}{l}0,929 \\
1,380\end{array}$ & 2,552 & & & & $\begin{array}{l}0,118 \\
0,055\end{array}$ & $\begin{array}{l}0,238 \\
0,101\end{array}$ & $\begin{array}{l}0,0,06 \\
0,150\end{array}$ & 0,051 & & & \\
\hline $0108030320021-1$ & $-0,618$ & $-0,618$ & & & & & & & $-0,534$ & $-0,534$ & & & & & & & 0,019 & & & & & & \\
\hline $0108030320022-1$ & $-0,796$ & $-0,796$ & & & & & & & $-1,930$ & $-1,930$ & & & & & & & 0,020 & & & & & & \\
\hline $\begin{array}{l}0108030320022-3 \\
0108030320023-2\end{array}$ & $\begin{array}{r}-1,441 \\
0,570\end{array}$ & $\begin{array}{r}-1,441 \\
0,570\end{array}$ & & & & & & & $\begin{array}{r}-2,715 \\
0,286\end{array}$ & $\begin{array}{r}-2,715 \\
0,286\end{array}$ & & & & & & & $\begin{array}{l}0,019 \\
0,018\end{array}$ & & & & & & \\
\hline
\end{tabular}


Tabel C.1: Item-parametre (continued)

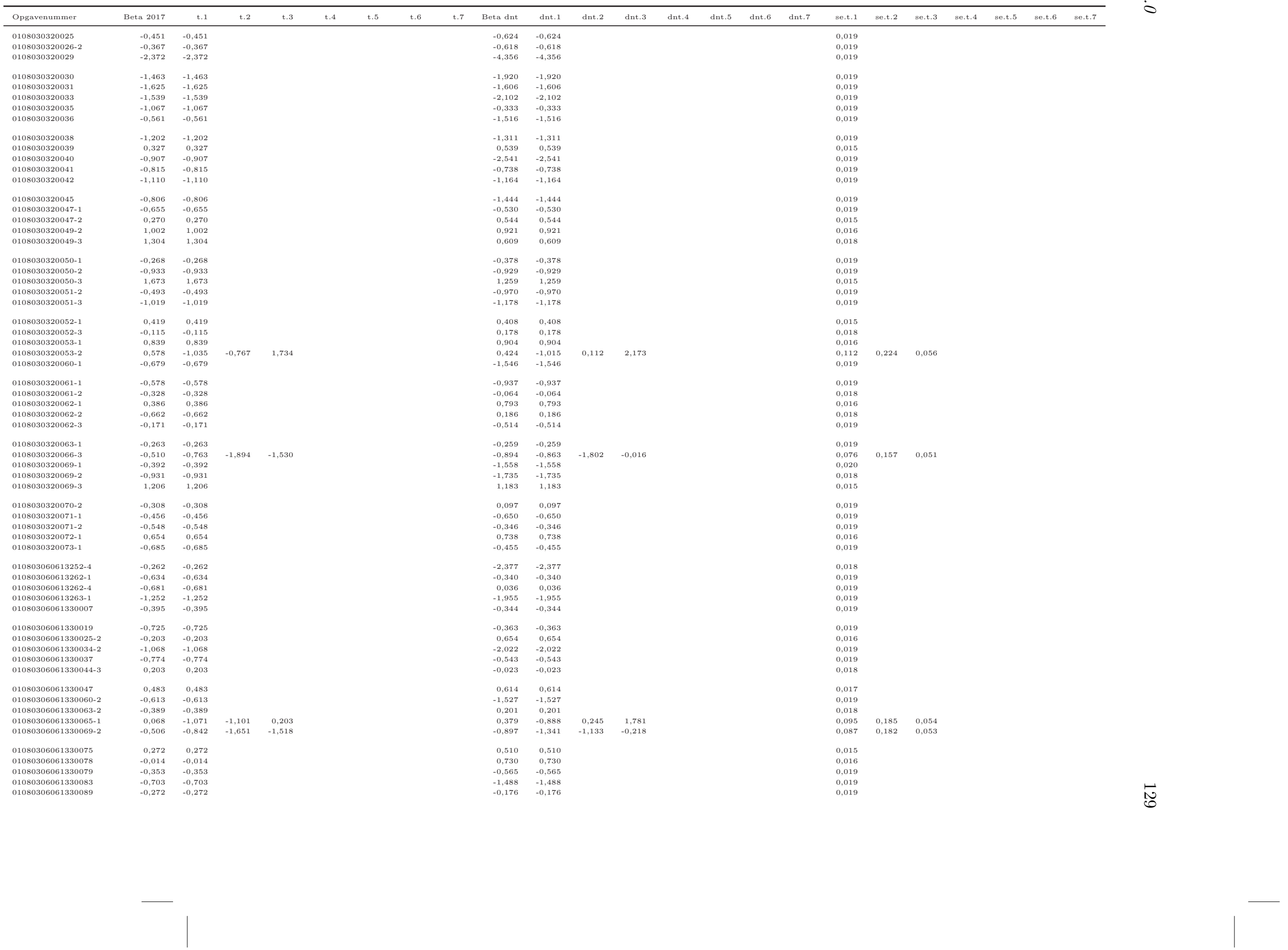


Tabel C.1: Item-parametre (continued)

\begin{tabular}{|c|c|c|c|c|c|c|c|c|c|c|c|c|c|c|c|c|c|c|c|c|c|c|c|}
\hline Opgavenummer & Beta 2017 & t.1 & t. 2 & t. 3 & t.4 & t.5 & t. 6 & $\mathrm{t} .7$ & Beta dnt & dnt. 1 & dnt.2 & dnt.3 & dnt. 4 & $\mathrm{dnt} .5$ & dnt. 6 & $\mathrm{dnt} .7$ & se.t.1 & se.t.2 & se.t.3 & se.t.4 & se.t.5 & se.t. 6 & se.t.7 \\
\hline 01080306061330093 & $-0,304$ & $-0,304$ & & & & & & & -0.174 & -0.174 & & & & & & & 0.019 & & & & & & \\
\hline 01080306061330094 & 0,143 & 0,143 & & & & & & & 0,158 & 0,158 & & & & & & & 0,018 & & & & & & \\
\hline 01080306061330095 & $-0,309$ & $-0,309$ & & & & & & & $-0,754$ & $-0,754$ & & & & & & & 0,019 & & & & & & \\
\hline 01080306061330097 & $-0,084$ & $-0,084$ & & & & & & & $-0,174$ & $-0,174$ & & & & & & & 0,019 & & & & & & \\
\hline 01080306061330099 & $-0,759$ & $-0,759$ & & & & & & & $-0,805$ & $-0,805$ & & & & & & & 0,019 & & & & & & \\
\hline 01080306061330100 & $-0,341$ & $-0,341$ & & & & & & & $-0,924$ & $-0,924$ & & & & & & & 0,019 & & & & & & \\
\hline 01080306061330101 & $-0,534$ & $-0,534$ & & & & & & & $-1,374$ & $-1,374$ & & & & & & & 0,019 & & & & & & \\
\hline 01080306061330104 & $-1,224$ & $-1,224$ & & & & & & & $-2,107$ & $-2,107$ & & & & & & & 0,019 & & & & & & \\
\hline 01080306061330109 & $-1,591$ & $-1,591$ & & & & & & & $-2,987$ & $-2,987$ & & & & & & & 0,019 & & & & & & \\
\hline 01080306061330112 & $-0,551$ & $-0,551$ & & & & & & & $-0,415$ & $-0,415$ & & & & & & & 0,019 & & & & & & \\
\hline 01080306061330113 & 0,157 & 0,157 & & & & & & & $-0,271$ & $-0,271$ & & & & & & & 0,019 & & & & & & \\
\hline 01080306061330114 & $-0,859$ & $-0,859$ & & & & & & & $-1,112$ & $-1,112$ & & & & & & & 0,019 & & & & & & \\
\hline 01080306061330115 & $-0,104$ & $-0,104$ & & & & & & & $-0,213$ & $-0,213$ & & & & & & & 0,019 & & & & & & \\
\hline $\begin{array}{l}01080306061330116 \\
01080306061330121\end{array}$ & $\begin{array}{r}-1,042 \\
0,054\end{array}$ & $\begin{array}{r}-1,042 \\
0,054\end{array}$ & & & & & & & $\begin{array}{c}-0,788 \\
0,261\end{array}$ & 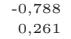 & & & & & & & $\begin{array}{l}0,019 \\
0.018\end{array}$ & & & & & & \\
\hline 01080306061330122 & -0.330 & -0.330 & & & & & & & 0.090 & 0.090 & & & & & & & 0.019 & & & & & & \\
\hline 01080306061330123 & $-0,140$ & $-0,140$ & & & & & & & 0,330 & 0,330 & & & & & & & 0,017 & & & & & & \\
\hline $010803060613353-1$ & $-1,011$ & $-1,011$ & & & & & & & $\begin{array}{l}-1,428 \\
-1,30 \\
-10\end{array}$ & $-1,428$ & & & & & & & 0,019 & & & & & & \\
\hline & $\begin{array}{r}-0,472 \\
0,275\end{array}$ & $\begin{array}{r}-0,472 \\
0,275\end{array}$ & & & & & & & $\begin{array}{l}0,476 \\
0.312\end{array}$ & $\begin{array}{l}0,476 \\
0,312\end{array}$ & & & & & & & $\begin{array}{l}0,015 \\
0,018\end{array}$ & & & & & & \\
\hline $01080306061340006-1$ & 0,275 & 0,275 & & & & & & & 0,312 & 0,312 & & & & & & & 0,018 & & & & & & \\
\hline 01080306061340013-1 & $-0,637$ & $-0,651$ & $-1,399$ & $-1,912$ & & & & & $-0,950$ & $-1,310$ & $-0,839$ & $-0,700$ & & & & & 0,115 & 0,252 & 0,055 & & & & \\
\hline 01080306061340014 & $-0,180$ & $-0,180$ & & & & & & & $-0,097$ & $-0,097$ & & & & & & & 0,018 & & & & & & \\
\hline 010803060613601-3 & $-2,332$ & $-2,332$ & & & & & & & $-3,409$ & $-3,409$ & & & & & & & 0,019 & & & & & & \\
\hline $\begin{array}{l}010803060613604-2 \\
010803060613903-2\end{array}$ & $\begin{array}{l}-1,228 \\
-0,420\end{array}$ & $\begin{array}{l}-1,228 \\
-0,420\end{array}$ & & & & & & & $\begin{array}{l}-1,020 \\
-0,733\end{array}$ & $\begin{array}{l}-1,020 \\
-0,733\end{array}$ & & & & & & & $\begin{array}{l}0,019 \\
0,019\end{array}$ & & & & & & \\
\hline 010803060613909-1 & $-0,857$ & $-0,857$ & & & & & & & $-0,886$ & $-0,886$ & & & & & & & 0,019 & & & & & & \\
\hline $0108030610350-1$ & $-0,336$ & $-0,336$ & & & & & & & 0,358 & 0,358 & & & & & & & 0,018 & & & & & & \\
\hline 0108030610352 & $-0,538$ & $-0,538$ & & & & & & & $-1,312$ & $-1,312$ & & & & & & & 0,019 & & & & & & \\
\hline 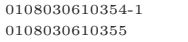 & $\begin{array}{r}-0,855 \\
0,790\end{array}$ & $\begin{array}{r}-0,855 \\
0,790\end{array}$ & & & & & & & $\begin{array}{r}-0,774 \\
1,345\end{array}$ & $\begin{array}{r}-0,774 \\
1,345\end{array}$ & & & & & & & $\begin{array}{l}0,019 \\
0,015\end{array}$ & & & & & & \\
\hline 0108030610358 & $-0,963$ & $-0,963$ & & & & & & & $-0,235$ & $-0,235$ & & & & & & & 0,019 & & & & & & \\
\hline 0108030610364-1 & $-0,045$ & $-0,045$ & & & & & & & 0,411 & 0,411 & & & & & & & 0,015 & & & & & & \\
\hline 0108030610364-2 & $-0,086$ & $-0,086$ & & & & & & & $-0,423$ & $-0,423$ & & & & & & & 0,019 & & & & & & \\
\hline $0108030610368-1$ & $-1,244$ & $-1,244$ & & & & & & & $-1,562$ & $-1,562$ & & & & & & & 0,019 & & & & & & \\
\hline 0108030610370 & 1,083 & 1,083 & & & & & & & $-0,394$ & $-0,394$ & & & & & & & 0,019 & & & & & & \\
\hline 0108030610383 & 0,241 & 0,241 & & & & & & & 0,942 & 0,942 & & & & & & & 0,016 & & & & & & \\
\hline 0108030610396 & $-1,127$ & $-1,127$ & & & & & & & $-1,150$ & $-1,150$ & & & & & & & 0,019 & & & & & & \\
\hline $\begin{array}{l}0108030610700-1 \\
0100030610000-2\end{array}$ & $\begin{array}{r}0,075 \\
-0,614\end{array}$ & $\begin{array}{r}0,075 \\
-0,614\end{array}$ & & & & & & & $-0,910$ & $-0,910$ & & & & & & & 0,019 & & & & & & \\
\hline $\begin{array}{l}\text { O108030610700-2 } \\
0108030610700-3\end{array}$ & $\begin{array}{r}-0,614 \\
0,155\end{array}$ & $\begin{array}{l}-0,614 \\
-1,287\end{array}$ & $-2,478$ & $-1,962$ & 0,620 & & & & $\begin{array}{l}-0,333 \\
-1,082\end{array}$ & $\begin{array}{l}-0,333 \\
-1,923\end{array}$ & $-2,212$ & $-0,805$ & 0,613 & & & & $\begin{array}{l}0,019 \\
0,078\end{array}$ & 0,151 & 0,245 & 0,065 & & & \\
\hline 0108030610702-2 & $-0,288$ & $-0,288$ & & & & & & & $-0,067$ & $-0,067$ & & & & & & & 0,018 & & & & & & \\
\hline 0108030610703-2 & $-0,462$ & $-0,462$ & & & & & & & $-0,416$ & $-0,416$ & & & & & & & 0,019 & & & & & & \\
\hline 0108030610705-1 & $-1,410$ & $-1,410$ & & & & & & & $-1,366$ & $-1,366$ & & & & & & & 0,019 & & & & & & \\
\hline $\begin{array}{l}0108030610705-2 \\
0108030610706-3\end{array}$ & $\begin{array}{l}-0,425 \\
-0,751\end{array}$ & $\begin{array}{l}-0,425 \\
-0,809\end{array}$ & $-1,570$ & $-2,801$ & $-3,002$ & & & & $\begin{array}{r}0,126 \\
-0,246\end{array}$ & $\begin{array}{l}0,1,26 \\
1,596\end{array}$ & $-1,218$ & $-1,111$ & $-0,252$ & & & & $\begin{array}{l}0,019 \\
0,145\end{array}$ & 0,290 & 0,447 & 0,075 & & & \\
\hline $0108030612006-1$ & $-1,461$ & $-1,461$ & & & & & & & $-2,179$ & $-2,179$ & & & & & & & 0,018 & & & & & & \\
\hline $0108030612006-2$ & $-1,097$ & $\begin{array}{l}-1,401 \\
-0,510\end{array}$ & $-1,525$ & $-2,239$ & $-3,746$ & $-5,483$ & & & $-1,127$ & $\begin{array}{l}-1,399 \\
-1,399\end{array}$ & $-0,520$ & $-0,733$ & $-1,340$ & $-1,643$ & & & 0,102 & 0,207 & 0,322 & 0,452 & 0,081 & & \\
\hline $0108030612007-1$ & $-0,393$ & $-0,393$ & & & & & & & 0,247 & 0,247 & & & & & & & 0,018 & & & & & & \\
\hline $\begin{array}{l}0108030612011-1 \\
0108030612012-1\end{array}$ & $\begin{array}{r}1,766 \\
-0,626\end{array}$ & $\begin{array}{r}1,766 \\
-0,626\end{array}$ & & & & & & & $\begin{array}{r}1,509 \\
-1,538\end{array}$ & $\begin{array}{r}1,509 \\
-1,588\end{array}$ & & & & & & & 0,014 & & & & & & \\
\hline 0108030612013-3 & $-0,264$ & $-0,264$ & & & & & & & $-0,482$ & $-0,482$ & & & & & & & 0,019 & & & & & & \\
\hline 0108030612014-1 & 0,589 & 0,589 & & & & & & & 0,782 & 0,782 & & & & & & & 0,016 & & & & & & \\
\hline $0108030612014-2$ & $-0,485$ & $-0,810$ & $-0,917$ & $-1,184$ & $-1,941$ & & & & $-0,626$ & $-1,108$ & $-0,659$ & 0,612 & $-1,348$ & & & & 0,148 & 0,310 & 0,513 & 0,074 & & & \\
\hline $\begin{array}{l}\text { O108030612014-3 } \\
0108030612015\end{array}$ & $\begin{array}{l}-0,155 \\
-0,552\end{array}$ & $\begin{array}{l}-0,573 \\
-0,552\end{array}$ & $-1,415$ & $-1,879$ & $-1,521$ & $-0,775$ & & & $\begin{array}{l}-0,287 \\
-0,750\end{array}$ & $\begin{array}{l}-0,725 \\
-0,750\end{array}$ & $-0,737$ & $-0,344$ & 0,106 & 0,266 & & & $\begin{array}{l}0,144 \\
0,019\end{array}$ & 0,277 & 0,411 & 0,580 & 0,090 & & \\
\hline $\begin{array}{l}0108030612019-1 \\
0108030612019-2\end{array}$ & $\begin{array}{l}-0,352 \\
-0,050\end{array}$ & $\begin{array}{l}-0,352 \\
-0,050\end{array}$ & & & & & & & $\begin{array}{l}-1,937 \\
-0,102\end{array}$ & $\begin{array}{l}-1,937 \\
-0,102\end{array}$ & & & & & & & $\begin{array}{l}0,019 \\
0,019\end{array}$ & & & & & & \\
\hline $\begin{array}{l}0108030612019-2 \\
010803019-2\end{array}$ & - 0,905 & $-1,479$ & $-2,767$ & $-1,696$ & $-3,621$ & & & & $-0,305$ & - & $-1,396$ & 2,318 & $-1,410$ & & & & 0,078 & 0,157 & 0,280 & 0,064 & & & \\
\hline $\begin{array}{l}0108030612024-2 \\
0108030612027\end{array}$ & $\begin{array}{l}-0,571 \\
-0,493\end{array}$ & $\begin{array}{l}-0,571 \\
-0,493\end{array}$ & & & & & & & $\begin{array}{l}-1,463 \\
-0,509\end{array}$ & $\begin{array}{l}-1,463 \\
-0,59\end{array}$ & & & & & & & $\begin{array}{l}0,019 \\
0,019\end{array}$ & & & & & & \\
\hline 0108030612038 & 0,135 & 0,135 & & & & & & & $-0,118$ & $-0,118$ & & & & & & & 0,019 & & & & & & \\
\hline 0108030612041 & $-0,046$ & $-0,046$ & & & & & & & 0,672 & 0,672 & & & & & & & 0,016 & & & & & & \\
\hline
\end{tabular}


Tabel C.1: Item-parametre (continued)

\begin{tabular}{|c|c|c|c|c|c|c|c|c|c|c|c|c|c|c|c|c|c|c|c|c|c|c|c|}
\hline Opgavenummer & Beta 2017 & t.1 & t.2 & t. 3 & t.4 & t. .5 & t. 6 & t. 7 & Beta dnt & dnt. 1 & dnt.2 & dnt. 3 & $\mathrm{dnt} .4$ & dnt. 5 & dnt. 6 & dnt. 7 & se.t.1 & se.t.2 & se.t.3 & se.t. 4 & se.t. 5 & se.t. 6 & se.t.7 \\
\hline $\begin{array}{l}0108030612047 \\
0108030615015-1\end{array}$ & $\begin{array}{l}-1,178 \\
-0,769\end{array}$ & $\begin{array}{l}-1,178 \\
-0,769\end{array}$ & & & & & & & $\begin{array}{r}0,051 \\
-0,805\end{array}$ & $\begin{array}{r}0,051 \\
-0,805\end{array}$ & & & & & & & $\begin{array}{l}0,019 \\
0,019\end{array}$ & & & & & & \\
\hline $0108030615015-2$ & $-0,247$ & $-0,247$ & & & & & & & 0,213 & 0,213 & & & & & & & 0,018 & & & & & & \\
\hline $0108030615016-1$ & $-0,953$ & $-0,953$ & & & & & & & $-0,665$ & $-0,665$ & & & & & & & 0,019 & & & & & & \\
\hline $0108030615016-2$ & $-0,428$ & $-0,428$ & & & & & & & $-0,284$ & $-0,284$ & & & & & & & 0,019 & & & & & & \\
\hline $\begin{array}{l}\text { O1080306910-1_2 } \\
\text { o1080306912-1__2 }\end{array}$ & $\begin{array}{r}1,260 \\
-0,783\end{array}$ & $\begin{array}{r}1,260 \\
-0,783\end{array}$ & & & & & & & $\begin{array}{l}1,054 \\
-2,330\end{array}$ & $\begin{array}{r}1,054 \\
-2,330\end{array}$ & & & & & & & $\begin{array}{l}0,014 \\
0,018\end{array}$ & & & & & & \\
\hline 01080306913-1_2 & 0,327 & 0,327 & & & & & & & 0,073 & 0,073 & & & & & & & 0,019 & & & & & & \\
\hline 01080306916-1_2 & $-1,114$ & $-1,114$ & & & & & & & $-0,624$ & $-0,624$ & & & & & & & 0,019 & & & & & & \\
\hline 01080306920-1_2 & 1,352 & 1,352 & & & & & & & 1,499 & 1,499 & & & & & & & $-5,297$ & & & & & & \\
\hline
\end{tabular}


Percentiler i den nye analyse fra 2017 og DNT 2017

I denne tabel er elevernes resultat fordelt i 100 lige store grupper af elever (percentilgrupper) med dygtighed i samme interval, og det er angivet hvad estimatet for den dygtigste elev i gruppen er. Percentilerne for DNT er baseret på de aktuelle dygtigheder i 2017, ikke de historiske dygtigheder som rapporteres til lærerne i nationale tests system (og som er en måde at muliggøre sammenligning over tid på).

Tabel D.1: Percentiler

\begin{tabular}{|c|c|c|c|c|c|c|}
\hline \multirow[b]{2}{*}{ Percentil } & \multicolumn{2}{|c|}{ Profilområde 1} & \multicolumn{2}{|c|}{ Profilområde 2} & \multicolumn{2}{|c|}{ Profilområde 3} \\
\hline & 2017 & DNT & 2017 & DNT & 2017 & DNT \\
\hline 1 & $-2,69$ & $-2,89$ & $-1,11$ & $-1,67$ & $-1,77$ & $-2,59$ \\
\hline 2 & $-2,23$ & $-2,26$ & $-0,76$ & $-0,85$ & $-1,40$ & $-2,00$ \\
\hline 3 & $-1,99$ & $-1,91$ & $-0,57$ & $-0,38$ & $-1,18$ & $-1,59$ \\
\hline 4 & $-1,82$ & $-1,69$ & $-0,43$ & $-0,13$ & $-1,02$ & $-1,26$ \\
\hline 5 & $-1,69$ & $-1,51$ & $-0,32$ & 0,06 & $-0,91$ & $-0,96$ \\
\hline 6 & $-1,57$ & $-1,35$ & $-0,23$ & 0,22 & $-0,82$ & $-0,75$ \\
\hline 7 & $-1,47$ & $-1,24$ & $-0,15$ & 0,37 & $-0,73$ & $-0,59$ \\
\hline 8 & $-1,40$ & $-1,16$ & $-0,08$ & 0,48 & $-0,67$ & $-0,47$ \\
\hline 9 & $-1,33$ & $-1,09$ & $-0,02$ & 0,57 & $-0,61$ & $-0,37$ \\
\hline 10 & $-1,26$ & $-1,04$ & 0,05 & 0,65 & $-0,55$ & $-0,29$ \\
\hline 11 & $-1,20$ & $-0,98$ & 0,11 & 0,74 & $-0,51$ & $-0,23$ \\
\hline 12 & $-1,15$ & $-0,93$ & 0,17 & 0,83 & $-0,46$ & $-0,17$ \\
\hline 13 & $-1,10$ & $-0,89$ & 0,22 & 0,92 & $-0,41$ & $-0,12$ \\
\hline 14 & $-1,05$ & $-0,84$ & 0,27 & 0,99 & $-0,37$ & $-0,07$ \\
\hline 15 & $-1,01$ & $-0,80$ & 0,32 & 1,05 & $-0,33$ & $-0,02$ \\
\hline 16 & $-0,96$ & $-0,76$ & 0,37 & 1,12 & $-0,29$ & 0,02 \\
\hline 17 & $-0,92$ & $-0,73$ & 0,41 & 1,18 & $-0,25$ & 0,06 \\
\hline 18 & $-0,88$ & $-0,69$ & 0,46 & 1,23 & $-0,22$ & 0,09 \\
\hline 19 & $-0,84$ & $-0,66$ & 0,49 & 1,28 & $-0,18$ & 0,13 \\
\hline 20 & $-0,80$ & $-0,62$ & 0,53 & 1,32 & $-0,15$ & 0,16 \\
\hline 21 & $-0,76$ & $-0,59$ & 0,57 & 1,37 & $-0,12$ & 0,19 \\
\hline 22 & $-0,73$ & $-0,56$ & 0,60 & 1,41 & $-0,08$ & 0,23 \\
\hline 23 & $-0,70$ & $-0,53$ & 0,64 & 1,45 & $-0,05$ & 0,26 \\
\hline 24 & $-0,66$ & $-0,50$ & 0,67 & 1,49 & $-0,02$ & 0,29 \\
\hline 25 & $-0,63$ & $-0,47$ & 0,71 & 1,54 & 0,01 & 0,32 \\
\hline 26 & $-0,60$ & $-0,44$ & 0,74 & 1,59 & 0,04 & 0,34 \\
\hline 27 & $-0,57$ & $-0,42$ & 0,77 & 1,63 & 0,07 & 0,37 \\
\hline 28 & $-0,54$ & $-0,39$ & 0,80 & 1,66 & 0,10 & 0,39 \\
\hline 29 & $-0,51$ & $-0,37$ & 0,83 & 1,71 & 0,13 & 0,42 \\
\hline 30 & $-0,48$ & $-0,34$ & 0,86 & 1,75 & 0,15 & 0,44 \\
\hline 31 & $-0,45$ & $-0,32$ & 0,89 & 1,79 & 0,18 & 0,46 \\
\hline 32 & $-0,42$ & $-0,30$ & 0,92 & 1,82 & 0,21 & 0,49 \\
\hline
\end{tabular}


Tabel D.1: Percentiler (continued)

\begin{tabular}{rrrrrrr}
\hline Percentil & 2017 & DNT & 2017 & DNT & 2017 & DNT \\
\hline 33 & $-0,39$ & $-0,27$ & 0,94 & 1,86 & 0,23 & 0,51 \\
34 & $-0,37$ & $-0,25$ & 0,97 & 1,89 & 0,26 & 0,53 \\
35 & $-0,34$ & $-0,23$ & 1,00 & 1,92 & 0,28 & 0,55 \\
36 & $-0,31$ & $-0,21$ & 1,03 & 1,95 & 0,31 & 0,57 \\
37 & $-0,29$ & $-0,19$ & 1,06 & 1,99 & 0,34 & 0,59 \\
38 & $-0,26$ & $-0,17$ & 1,08 & 2,02 & 0,36 & 0,61 \\
39 & $-0,23$ & $-0,14$ & 1,11 & 2,05 & 0,39 & 0,64 \\
40 & $-0,21$ & $-0,12$ & 1,14 & 2,09 & 0,42 & 0,66 \\
41 & $-0,18$ & $-0,10$ & 1,17 & 2,12 & 0,44 & 0,68 \\
42 & $-0,16$ & $-0,08$ & 1,20 & 2,15 & 0,47 & 0,70 \\
43 & $-0,13$ & $-0,07$ & 1,22 & 2,19 & 0,50 & 0,73 \\
44 & $-0,11$ & $-0,05$ & 1,25 & 2,22 & 0,52 & 0,75 \\
45 & $-0,08$ & $-0,03$ & 1,28 & 2,25 & 0,55 & 0,78 \\
46 & $-0,06$ & $-0,01$ & 1,30 & 2,27 & 0,58 & 0,81 \\
47 & $-0,04$ & 0,01 & 1,33 & 2,30 & 0,60 & 0,84 \\
48 & $-0,01$ & 0,03 & 1,35 & 2,33 & 0,63 & 0,86 \\
49 & 0,01 & 0,05 & 1,38 & 2,36 & 0,66 & 0,89 \\
50 & 0,03 & 0,07 & 1,40 & 2,39 & 0,68 & 0,92 \\
51 & 0,05 & 0,08 & 1,43 & 2,41 & 0,71 & 0,95 \\
52 & 0,08 & 0,11 & 1,45 & 2,44 & 0,74 & 0,98 \\
53 & 0,10 & 0,13 & 1,48 & 2,47 & 0,77 & 1,01 \\
54 & 0,13 & 0,15 & 1,50 & 2,50 & 0,79 & 1,04 \\
55 & 0,15 & 0,17 & 1,53 & 2,52 & 0,82 & 1,07 \\
56 & 0,17 & 0,19 & 1,55 & 2,55 & 0,85 & 1,10 \\
57 & 0,20 & 0,21 & 1,58 & 2,58 & 0,87 & 1,13 \\
58 & 0,22 & 0,24 & 1,60 & 2,60 & 0,90 & 1,16 \\
59 & 0,25 & 0,26 & 1,63 & 2,63 & 0,93 & 1,19 \\
60 & 0,27 & 0,28 & 1,65 & 2,66 & 0,95 & 1,22 \\
61 & 0,30 & 0,31 & 1,68 & 2,69 & 0,98 & 1,25 \\
62 & 0,33 & 0,33 & 1,70 & 2,71 & 1,01 & 1,28 \\
63 & 0,35 & 0,35 & 1,73 & 2,73 & 1,03 & 1,31 \\
64 & 0,38 & 0,38 & 1,75 & 2,76 & 1,06 & 1,34 \\
65 & 0,40 & 0,40 & 1,77 & 2,78 & 1,09 & 1,37 \\
66 & 0,43 & 0,42 & 1,80 & 2,81 & 1,11 & 1,40 \\
67 & 0,45 & 0,45 & 1,83 & 2,84 & 1,14 & 1,44 \\
68 & 0,48 & 0,47 & 1,86 & 2,86 & 1,17 & 1,47 \\
69 & 0,51 & 0,49 & 1,88 & 2,89 & 1,20 & 1,50 \\
70 & 0,53 & 0,52 & 1,91 & 2,92 & 1,22 & 1,54 \\
71 & 0,56 & 0,54 & 1,94 & 2,95 & 1,25 & 1,58 \\
72 & 0,59 & 0,57 & 1,97 & 2,98 & 1,28 & 1,61 \\
73 & 0,62 & 0,59 & 2,00 & 3,01 & 1,31 & 1,65 \\
74 & 0,64 & 0,62 & 2,02 & 3,03 & 1,34 & 1,68 \\
75 & 0,67 & 0,65 & 2,05 & 3,06 & 1,37 & 1,73 \\
76 & 0,71 & 0,68 & 2,08 & 3,09 & 1,41 & 1,77 \\
77 & 0,74 & 0,71 & 2,11 & 3,12 & 1,44 & 1,80 \\
78 & 0,77 & 0,75 & 2,14 & 3,14 & 1,47 & 1,84
\end{tabular}


Tabel D.1: Percentiler (continued)

\begin{tabular}{rrrrrrr}
\hline Percentil & 2017 & DNT & 2017 & DNT & 2017 & DNT \\
\hline 79 & 0,81 & 0,79 & 2,17 & 3,18 & 1,51 & 1,88 \\
80 & 0,84 & 0,83 & 2,21 & 3,22 & 1,54 & 1,92 \\
81 & 0,87 & 0,88 & 2,25 & 3,26 & 1,58 & 1,97 \\
82 & 0,91 & 0,93 & 2,29 & 3,29 & 1,62 & 2,02 \\
83 & 0,96 & 0,98 & 2,32 & 3,34 & 1,66 & 2,06 \\
84 & 1,00 & 1,05 & 2,36 & 3,38 & 1,70 & 2,11 \\
85 & 1,05 & 1,12 & 2,40 & 3,42 & 1,75 & 2,16 \\
86 & 1,10 & 1,21 & 2,44 & 3,47 & 1,79 & 2,21 \\
87 & 1,16 & 1,29 & 2,49 & 3,53 & 1,84 & 2,27 \\
88 & 1,23 & 1,40 & 2,54 & 3,58 & 1,89 & 2,33 \\
89 & 1,30 & 1,55 & 2,59 & 3,65 & 1,95 & 2,40 \\
90 & 1,38 & 1,70 & 2,65 & 3,69 & 2,01 & 2,46 \\
91 & 1,49 & 1,86 & 2,72 & 3,78 & 2,07 & 2,54 \\
92 & 1,61 & 2,07 & 2,80 & 3,87 & 2,14 & 2,62 \\
93 & 1,72 & 2,28 & 2,87 & 3,93 & 2,21 & 2,70 \\
94 & 1,87 & 2,43 & 2,96 & 4,02 & 2,29 & 2,79 \\
95 & 2,03 & 2,61 & 3,07 & 4,16 & 2,41 & 2,92 \\
96 & 2,19 & 2,79 & 3,19 & 4,27 & 2,53 & 3,05 \\
97 & 2,39 & 2,98 & 3,34 & 4,47 & 2,67 & 3,20 \\
98 & 2,63 & 3,20 & 3,54 & 4,67 & 2,87 & 3,41 \\
99 & 3,07 & 3,63 & 3,99 & 5,32 & 3,18 & 3,75 \\
100 & 5,58 & 6,73 & 6,86 & 7,00 & 5,17 & 6,24 \\
\hline
\end{tabular}




\section{Ministeriets visning af kriteriebaserede scores}

I dette bilag vises nogle eksempler på ministeriets brug af kriteriebaserede scores. Figurerne stammer fra Styrelsen for It og Læring (2016a) og Styrelsen for It og Læring (2017).

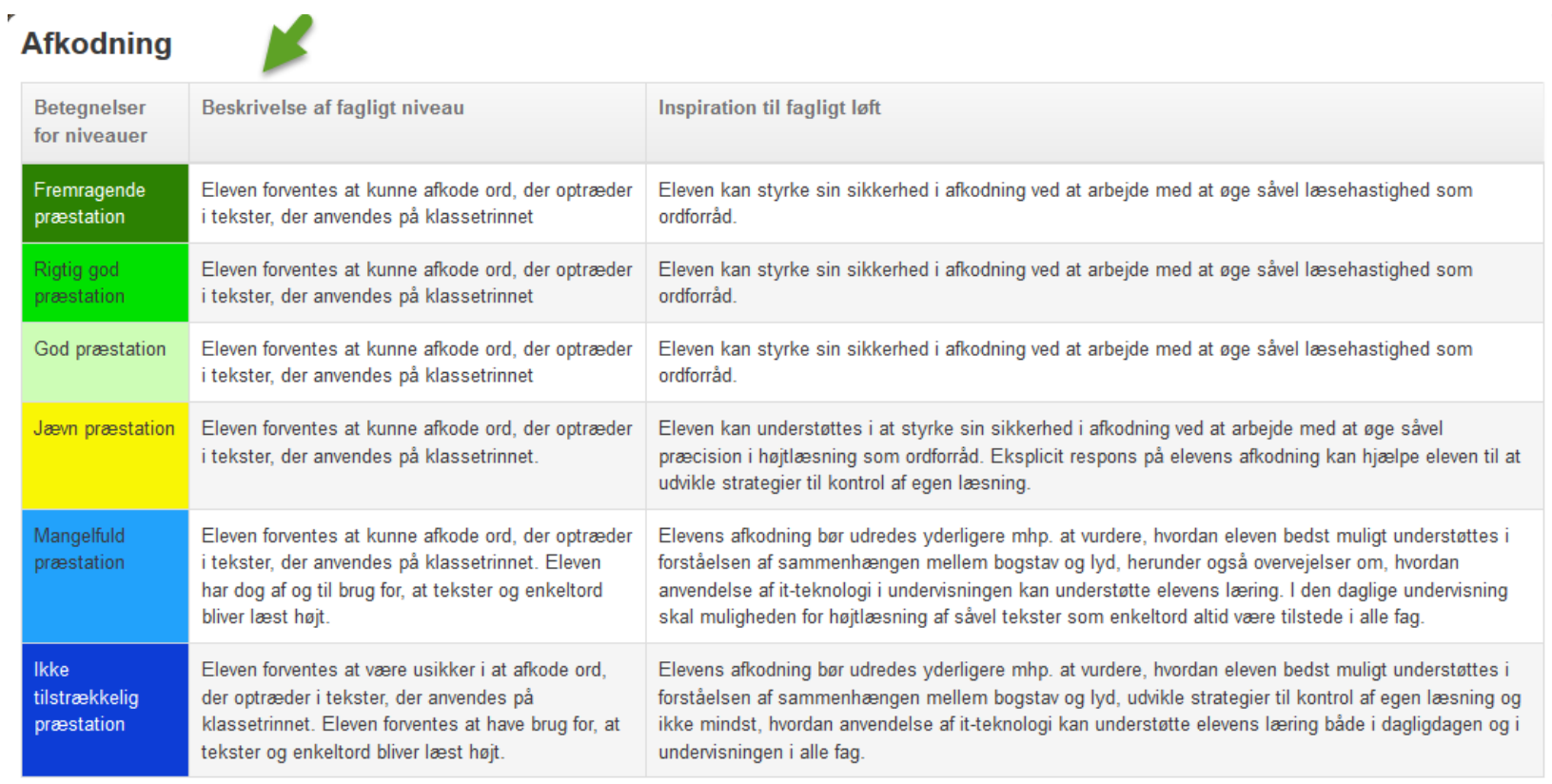

Figur E.1 Beskrivelser af de faglige niveauer (for afkodning) 


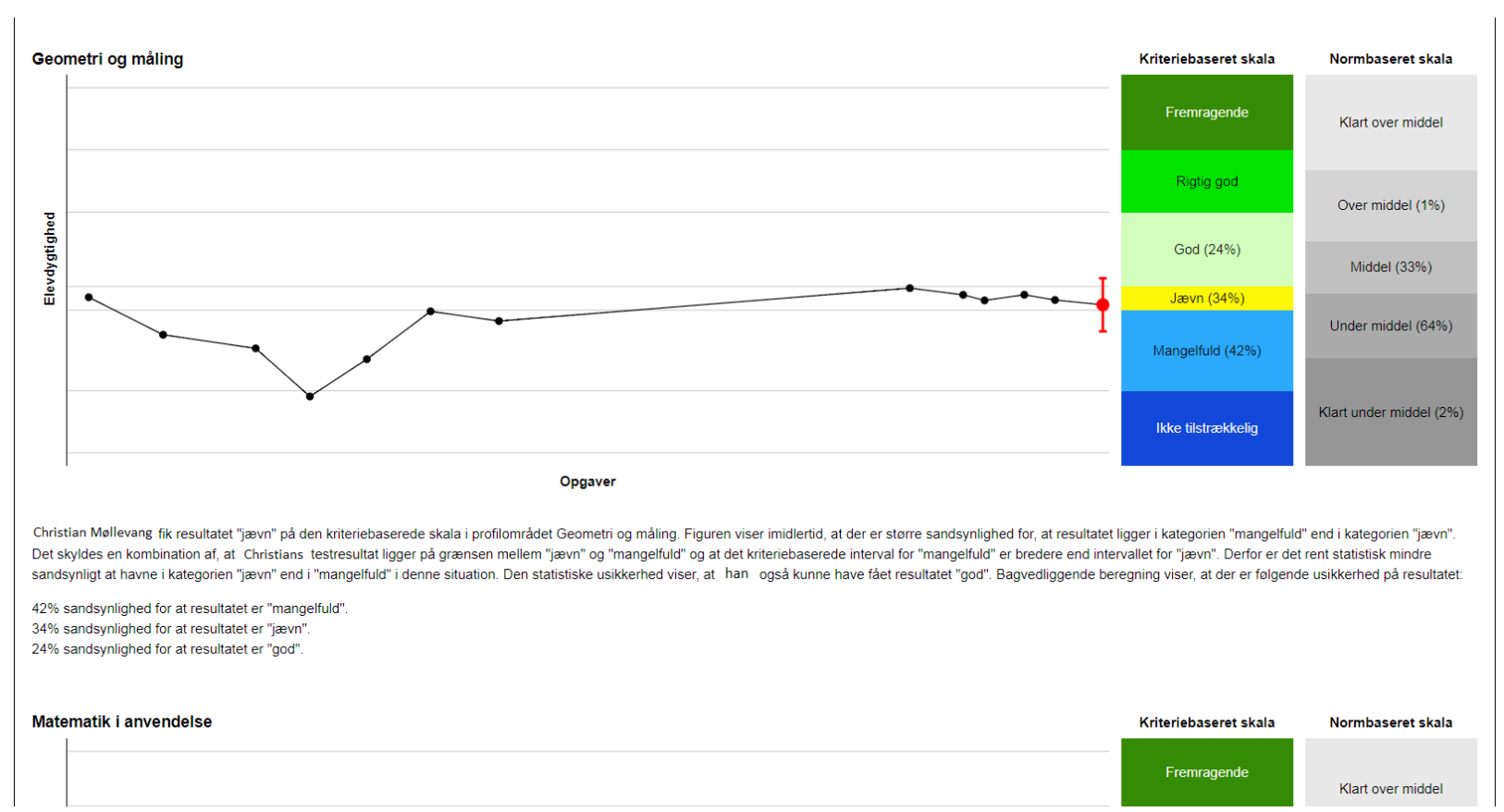

Figur E.2 Visning af testforløb og statistisk usikkerhed i forhold til de kriteriebaserede scores. 


\section{$\mathbf{F}$ \\ Georg Breddams notat om nationale test}

De følgende sider er gengivet med tilladelse fra Georg Breddam og opsummerer de iagttagelser han havde gjort sig før henvendelsen til os. 


\section{De nationale tests set fra lærerperspektiv.}

Starten for min interesse for DNT ligger år tilbage ved en frivillig test. Jeg studsede over et par elevresultater. Ved nærmere kig på dem, rejste sig bl.a. spørgsmålet omkring god/dårlig start og "fastholdelse" på tidligt estimeret niveau?

Jeg skrev et brev til styrelsen for Undervisning og Kvalitet og fik svaret, at alt var i orden i forhold til det adaptive princip. Særligt den afsluttende bemærkning i svaret vakte min nysgerrighed:

Kort sagt: Dine elevers testforløb ser, i lyset af det adaptive princip, fine ud. De er dog begge eksempler på elever, der enten starter rigtig dårligt eller rigtig godt.

Jeg håber, at du kan bruge mine svar.

Mange hilsner,

xxxxxx

Ifølge min opfattelse af et adaptivt testforløb burde starten være mindre væsentlig.

\section{Spørgsmål der rejste sig:}

- Er testen adaptiv i "folkelig forståelse"?

- Når testen beskrives som adaptiv/tilpasser sig den enkelte elevs niveau, er det for mig påfaldende, hvor meget en god/dårlig start sætter sit præg langt hen i testforløbet i de enkelte profilområder - stiafhængighed?

- Hvorledes/hvordan kan testen kategorisere forskellige elever med samme svarmønster vidt forskelligt ved at stoppe forskellige steder i forløbet af items? Nogle elever får mange spørgsmål - mens andre "godkendes" med væsentlig færre spørgsmål i samme profilområde?

Ovenstående gav anledning til et forsøg i den frivillige test. Mine elever fik hjælp til at svare i forudbestemte svarmønstre. God/dårlig start - overspring af opgaver - osv. Blot for at teste testen.

Gennemgik resultaterne, og de underbyggede min fornemmelse. Siden da er jeg flere gange stødt på den samme problematik, som ovenstående spørgsmål er udtryk for.

Efter flere års "frustration" måtte mine antagelser stå sin prøve. Efter artikel i Folkeskolen 7.nov 2018 omkring anbefalinger til evaluering af De nationale Tests tog jeg chancen og kontaktede Jeppe Bundsgård, som en ekspert på området. Vi fik et møde i stand og jeg fremlagde mine resultater og spørgsmål. Jeppe Bundsgård var lydhør og interesseret og gik derefter i gang med hans egne analyser med et videnskabeligt udgangspunkt. 


\section{1. "Stiafhængighed"?}

Eksempel på god start og lang fastholdelse i høj sværhedsgrad:

Et eksempel på Tal og Algebra-sekvens.

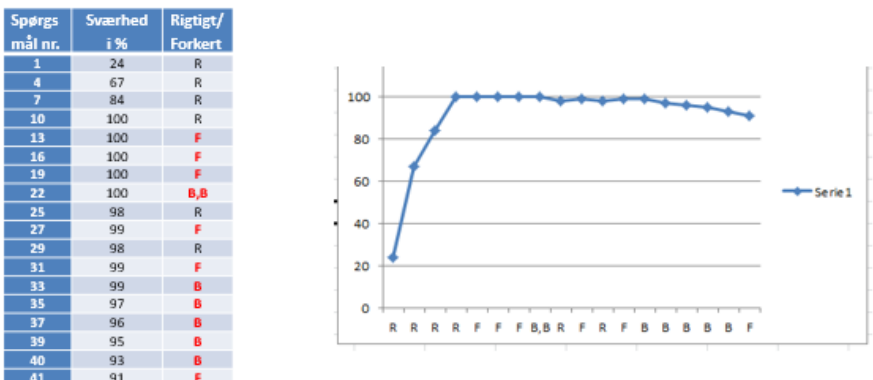

6 rigtige -6 forkerte -7 oversprungne

Bedømmelse: Rigtig god. (Fremragende-Rigtig god-God-Jævn-Mangelfuld-Ikke

tilfredsstillende)

Eksempel på dårlig start (B er oversprunget spørgsmål = fejl) og lang fastholdelse i minimal sværhedsgrad på trods af mange rigtige:

Et eksempel på Tal og Algebra-sekvens.

\begin{tabular}{|c|c|c|}
\hline $\begin{array}{c}\text { Spsrgs } \\
\text { malnn. }\end{array}$ & $\begin{array}{c}\text { Svereched } \\
\text { i\% }\end{array}$ & $\begin{array}{c}\text { Rigtigt/ } \\
\text { Forkert }\end{array}$ \\
\hline 1 & 22 & B \\
\hline 4 & 21 & $B$ \\
\hline 7 & 12 & $B$ \\
\hline 10 & 1 & $B$ \\
\hline 13 & 1 & $R$ \\
\hline 16 & 1 & $R$ \\
\hline 19 & 1 & $R$ \\
\hline 22 & 1 & $R$ \\
\hline 25 & 1 & $R$ \\
\hline 28 & 1 & $R$ \\
\hline 31 & 2 & $R$ \\
\hline 34 & 4 & $R$ \\
\hline 37 & 6 & $B, B, B$ \\
\hline 45 & 3 & $R$ \\
\hline 48 & 4 & $R$ \\
\hline
\end{tabular}

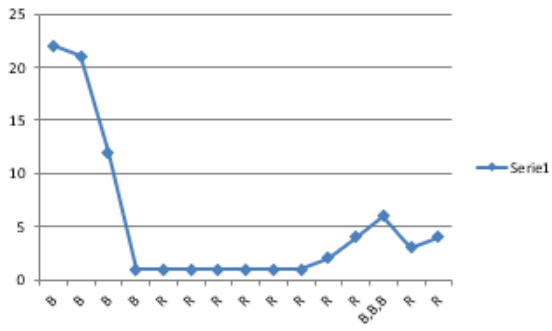

10 rigtige -0 forkerte -7 oversprungne

Bedømmelse: Mangelfuld. (Fremragende-Rigtig god-God-Jævn-Mangelfuld-lkke tilfredsstillende)

Læg mærke til midterste kolonne, hvor sværhedsgraden af de enkelte spørgsmål fremgår på en skala fra 1-100. Ikke store udsving i forhold til den - efter 3-4 startspørgsmål estimerede elevdygtighed.

Figur F.1 Enhederne på figurerne er percentilscores på y-aksen og itemnummer i elevens forløb på x-aksen (JB og SK). 


\section{Tilfældige stop i testforløb:}

Nedenstående elev har svaret forkert på de 4 første spørgsmål i hver af de 3 profilområder. Derefter er alle rigtige.

Hvorfor stopper testen langt før i geometridelen end i de 2 andre? (Prikker er spørgsmål) Alle 3 kurver er opadgående. Har eleven nået sit niveau efter en dårlig "nervøs" start??

Figurerne på denne side viser xx's testforløb i hvert enkelt profilområde. Den røde prik viser $x x$ 's testresultat. Der er imidlertid statistisk usikkerhed forbundet med alle test, og derfor kan det ikke udelukkes, at xx's testresultat kunne være lidt højere eller lavere. Den røde linje viser den statistiske usikkerhed $i$ form af et interval, som xx's testresultat med stor sandsynlighed ligger indenfor.
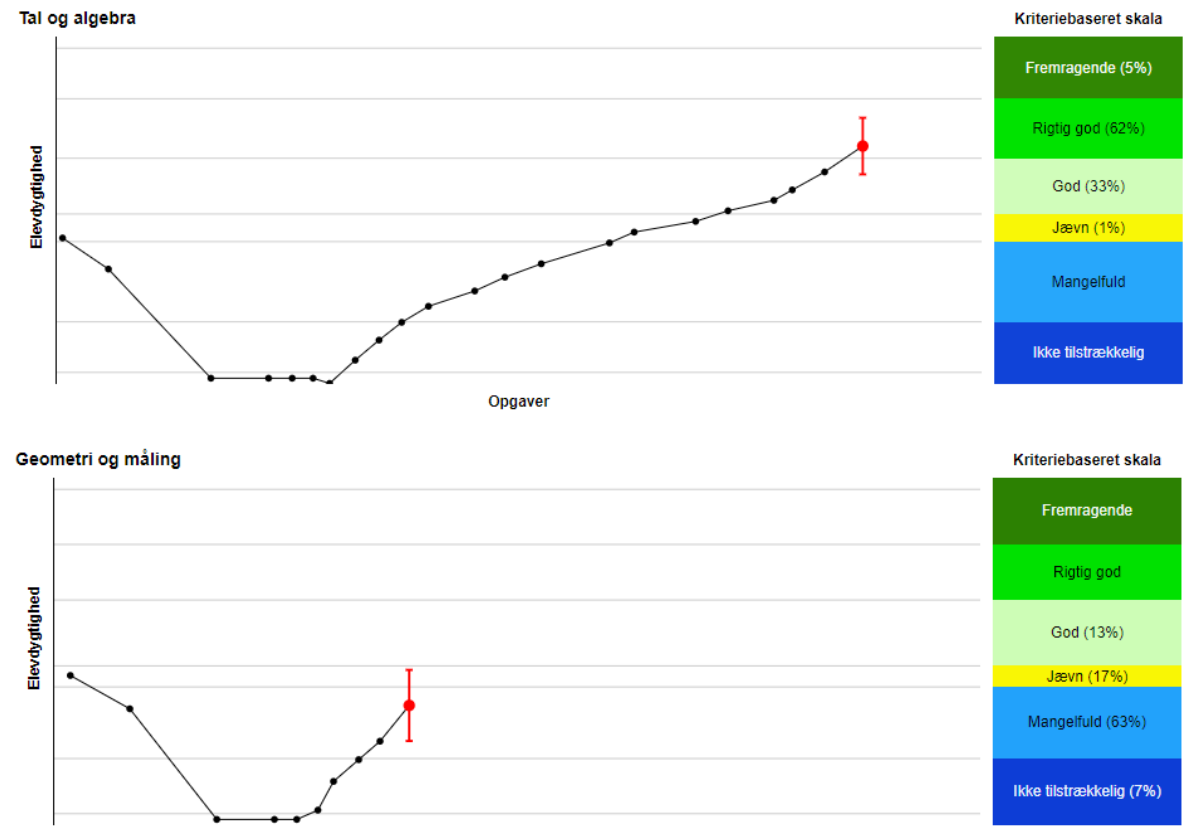

Opgaver
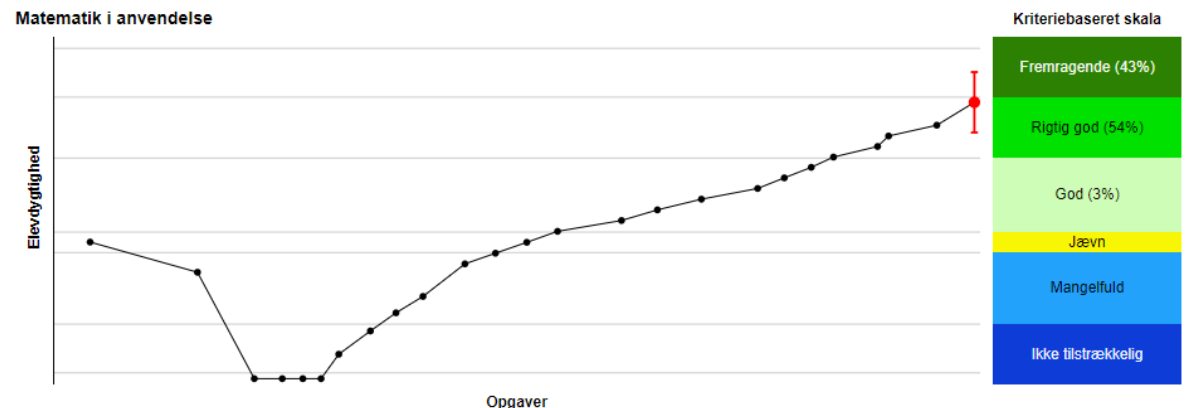

Figur F.2 Figurerne stammer fra ministeriets visning af resultater til lærerne. Enhederne på figurerne er formentlig rasch-scores på y-aksen og itemnummer i elevens forløb på x-aksen (JB og SK). 
F.O 


\section{Bilag. Gennemgang af konsekvenser af fejl ved beregning af itemsværhedsgrader}

Morten Rasmus Puck opdagede ved læsning af denne rapport at der var en række fejl i den tabel over itemsværhedsgrader der er gengivet i bilag C. Ved gennemgang af vores scripts til produktion af de data der indgår i tabellen, opdagede vi at der var sket en fejl som betød at item-location for polytome items (som kun findes i profilområde 3) var blevet indskrevet i profilområde 1 og derved havde overskrevet de korrekte sværhedsgrader. Det betød at 90 items havde fået forkerte sværhedsgrader i profilområde 1, og at 90 items i profilområde 3 var sat lig med den første kategoris threshold. Profilområde 2 er ikke påvirket af fejlen.

Fejlen har alene konsekvenser for de figurer der gengiver forskelle i itemsværhedsgrader mellem 2017-analysen og DNT-analysen. I alle øvrige analyser har vi ikke anvendt disse omregnede værdier.

I det følgende viser vi med samme figurer som i kapitel 4 hvad denne fejl konkret betyder for vores analyser. Sidst i bilaget gengiver vi en tabel der sammenligner alle forkerte og korrekte værdier.

Som det fremgår af figur G.1 er der ingen forskel mellem itemsværhedsgrader i profilområde 2. I profilområde 3 betød fejlen at en række items primært med sværhedsgrader omkring 0 logit var blevet givet sværhedsgrader der for de flestes vedkommende lå under 0 , og for en dels vedkommende langt under 0 . For profilområde 1 , som jo ved fejlen havde fået tildelt forkerte sværhedsgrader, er der tale om items som ifølge DNT's analyser ligger over hele spektret, men som ved fejlen for de flestes vedkommende blev givet sværhedsgrader tættere på 0 logit. 

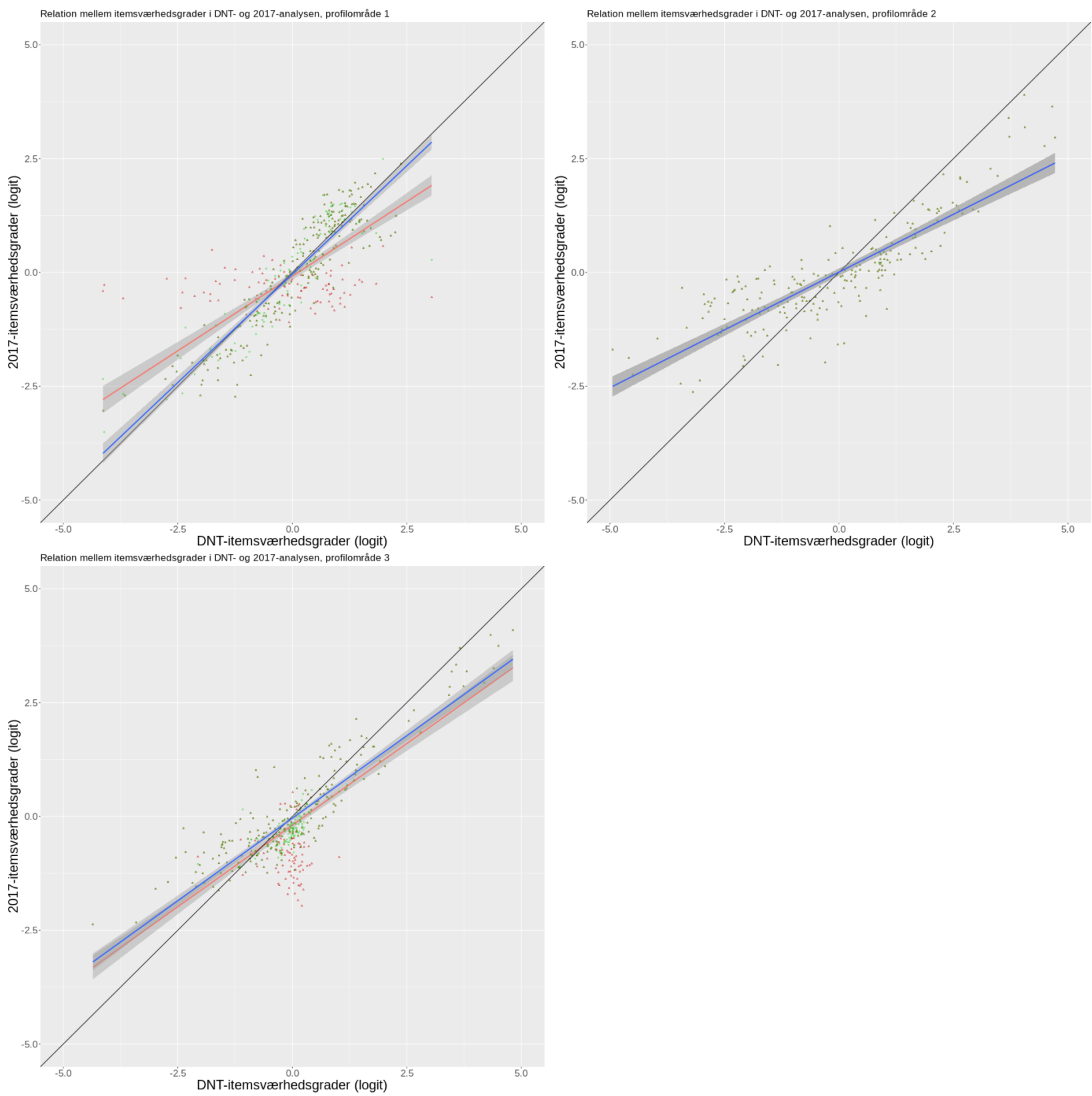

Figur G.1 Sammenligning af den korrekte og den forkerte sammenligning af 2017-analysens og DNT's estimat af sværhedsgrader for de tre profilområder. Der er indtegnet en sort identitetslinje og en blå linje med konfidensinterval der viser den korrekte regression af 2017-værdier på DNT-værdier. Med rød linje er indtegnet den forkerte regression med konfidensinterval. De grønne prikker er de korrekte itemsværhedsgrader, mens de røde trekanter er de forkerte itemsværhedsgrader. De items der ikke har fået ændret deres sværhedsgrad, fremstår mørkere (fordi der både er en grøn prik og en rød trekant).

Figur G.2 viser forskellen på den korrekte og den forkerte analyses identifikation af forskelle mellem DNT's og 2017-analysens estimat af itemsværhedsgrader plottet som funktioner af DNT-sværhedsgraderne.

Som det fremgår har de forkerte itemsværhedsgrader haft en stor betydning for hvordan fordelingen af uoverensstemmelser mellem 2017-analysen og DNT-analysens itemsværhedsgrader ser ud. Hvor de forkerte sværhedsgrader gav indtryk af at det særligt var de lette items der var blevet sværere, og de svære der 
var blevet lettere, giver den korrekte analyse indtryk af at der er tale om en jævnt fordelt uenighed om sværhedsgraderne.

For profilområde 3 er hældningen den samme, og både de forkerte og de korrekte forskelle på itemsværhedsgrader støtter en konklusion om at lette items i profilområde 3 er blevet sværere, mens svære items er blevet lettere. Forskydningen af den korrekte regressionslinje opad viser at der dog ikke er tale om at de er blevet helt så meget lettere over en bred kam som den forkerte analyse angav. 

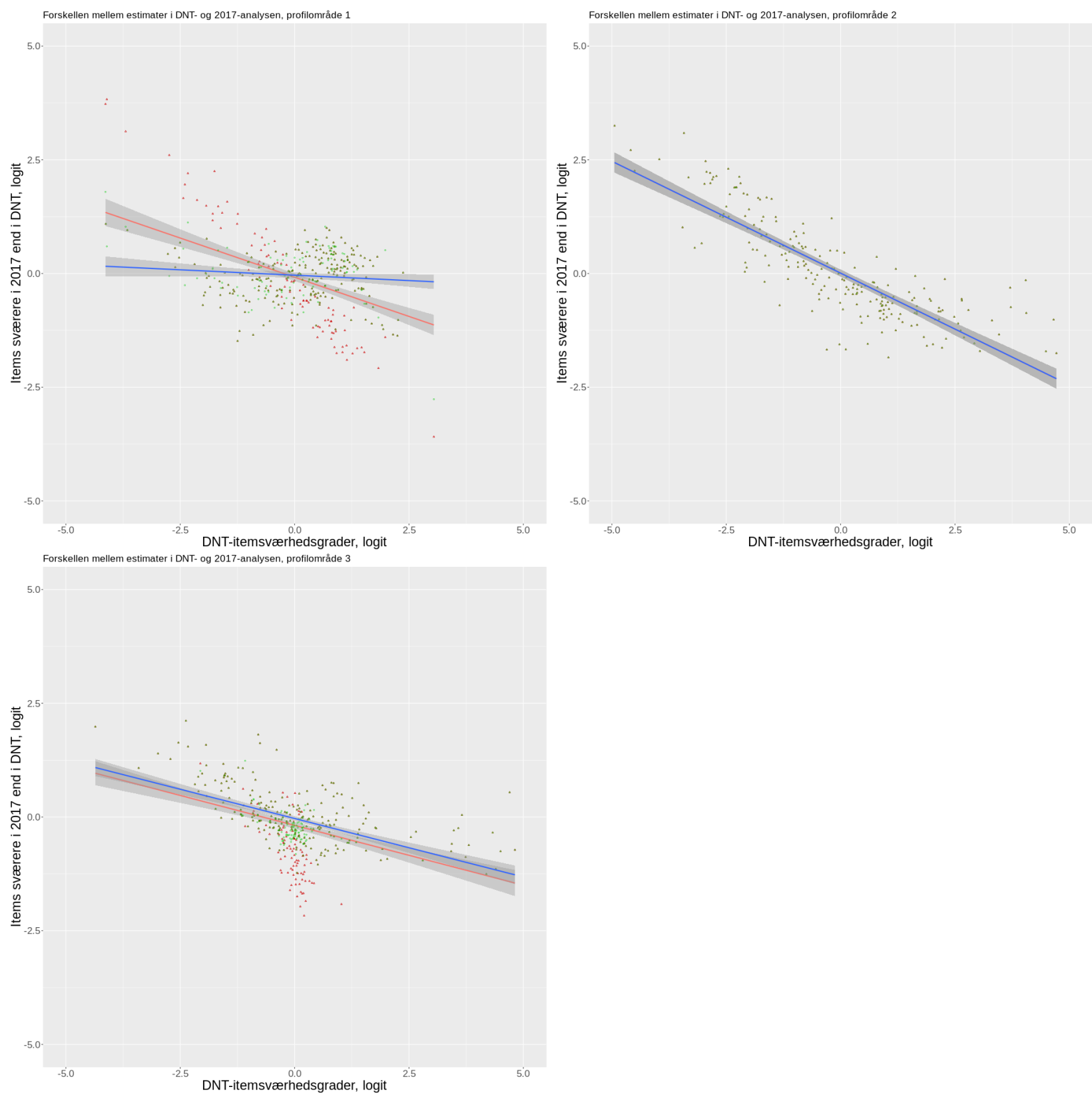

Figur G.2 Sammenligning af den korrekte og den forkerte analyses identifikation af forskelle mellem 2017analysens og DNT's estimat af sværhedsgrader for de tre profilområder i forhold til sværhedsgraden i DNT. Der er indtegnet en blå linje med konfidensinterval der viser den korrekte regression af forskellen på 2017-værdier og DNT-værdier. Med rød linje er indtegnet den forkerte regression af forskellene med konfidensinterval. De grønne prikker er de korrekte forskelle i itemsværhedsgrader, mens de røde trekanter er de forkerte forskelle i itemsværhedsgrader. De items der ikke har fået ændret deres sværhedsgrad, fremstår mørkere (fordi der både er en grøn prik og en rød trekant).

Histogrammerne i figur G.3 viser forskellen mellem den forkerte og den korrekte analyses fordeling af den absolutte forskel på de to estimater af sværhedsgraden for de tre profilområder.

Som det fremgår er der generelt tale om at der er færre meget store forskelle i den korrekte analyse i både profilområde 1 og 3 . Men der er dog stadig tale om at 96 items udviser en forskel der er større end 0,5 logit 
i profilområde 1, mens det drejer sig om 99 items der udviser en forskel større end 0,5 logit i profilområde 3. For profilområde 2 er det fortsat 149 items der udviser forskelle over 0,5 logit.

Den korrekte gennemsnitlige absolutte forskel er henholdsvis 0,42, 0,91 og 0,44, mens den forkerte gennemsnitlige absolutte forskel var henholdsvis $0,61,0,91$ og 0,59
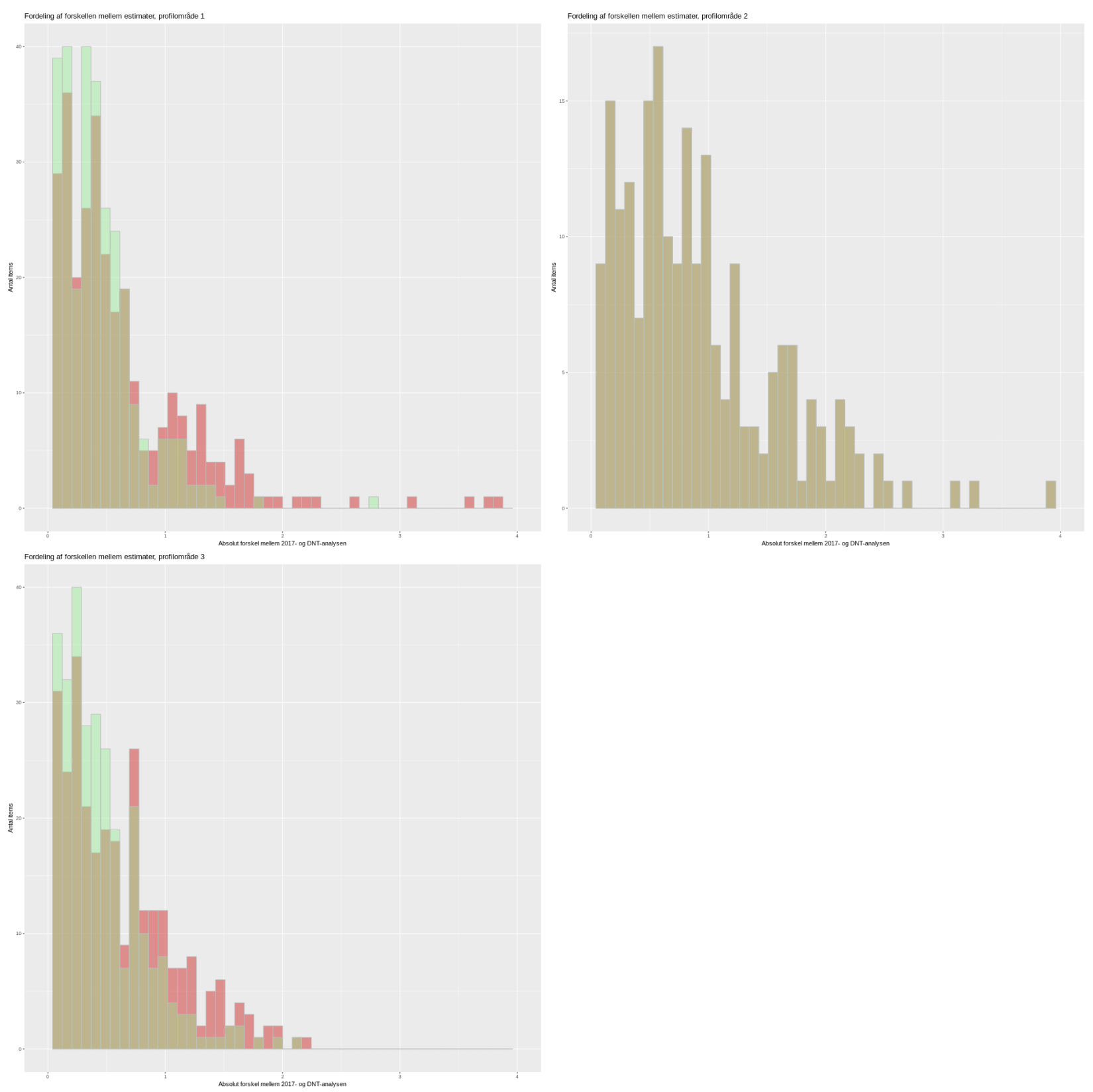

Figur G.3 Forskellen på fordelingen af forskelle mellem 2017-analysens og DNT's estimater af sværhedsgrader for de tre profilområder. De røde søjler viser de forkerte beregninger, mens de grønne viser de korrekte. De brune angiver der hvor der er overlap mellem de to analyser. 


\section{G.1 Vurdering af konsekvenser af de forkerte beregninger}

Som det fremgår af figurerne og tabellen (tabel G.1) i næste afsnit, har de forkerte itemsværhedsgrader generelt betydet at forskellene så større ud end de var. Men som det også fremgår, så ændrer fejlen ikke på at der er tale om meget store forskelle mellem DNT's og den korrekte 2017-analyses estimat af itemsværhedsgrader. Således gælder det for alle tre profilområder at mere end 90 items udviser forskelle der er større end 0,5 logit. Vi ser således ingen grund til at ændre de konklusioner som vi har foretaget i rapporten.

\section{G.2 Tabel over forkerte og korrekte værdier}

Tabel G.1: Oversigt over forkerte og korrekte itemsværhedsgrader.

\begin{tabular}{cccc}
\hline Item & Korrekt værdi & Forkert værdi & Forskel i værdi \\
\hline $010801000301238925-1$ & 1.35 & -0.02 & 1.36 \\
$010801000301238994-1$ & -1.04 & -0.03 & -1.02 \\
$010801000301238995-1$ & -0.26 & -0.51 & 0.24 \\
$010801000301238996-1$ & 0.28 & -0.06 & 0.34 \\
$010801000301238999-1$ & 0.94 & -0.07 & 1.01 \\
$010801000301239000-1$ & 1.45 & -0.28 & 1.73 \\
$010801000301239195-1$ & 1.32 & -0.39 & 1.71 \\
$010801000301239235-1$ & -0.11 & -0.08 & -0.03 \\
0108010410080 & -2.66 & -0.44 & -2.21 \\
0108010410088 & 1.30 & -0.25 & 1.55 \\
0108010410093 & -1.36 & -0.58 & -0.77 \\
0108010410094 & 0.86 & -0.25 & 1.11 \\
0108010410098 & -1.74 & -0.32 & -1.42 \\
$0108010410110-1$ & -0.89 & -0.24 & -0.65 \\
$0108010410145-1$ & 1.22 & -0.26 & 1.48 \\
$0108010410155-1$ & 0.35 & -0.16 & 0.50 \\
$0108010410186-1$ & -3.51 & -0.28 & -3.23 \\
$0108010410187-1$ & -1.09 & 0.36 & -1.44 \\
0108010410230005 & 0.13 & -0.33 & 0.46 \\
0108010410230008 & -0.29 & -0.40 & 0.12 \\
0108010410230009 & 0.08 & -0.41 & 0.50 \\
0108010410230012 & 1.02 & -0.29 & 1.31 \\
0108010410230013 & 0.42 & -0.26 & 0.68 \\
0108010410230018 & -0.72 & -0.25 & -0.47 \\
0108010410230019 & 0.74 & -0.33 & 1.07 \\
0108010410230020 & -0.18 & -0.80 & 0.63 \\
0108010410230021 & -0.59 & -0.22 & -0.37 \\
0108010410230022 & 0.11 & -0.55 & 0.66 \\
0108010410230023 & 0.95 & -0.34 & 1.29 \\
0108010410230024 & 1.27 & -0.46 & 1.73 \\
& & &
\end{tabular}


Tabel G.1: Oversigt over forkerte og korrekte itemsværhedsgrader. (continued)

\begin{tabular}{|c|c|c|c|}
\hline Item & Korrekt værdi & Forkert værdi & Forskel i værdi \\
\hline 0108010410230025 & -1.56 & -0.17 & -1.39 \\
\hline 0108010410230028 & 0.21 & -0.30 & 0.50 \\
\hline 0108010410230029 & -0.98 & -0.17 & -0.81 \\
\hline 0108010410230030 & -0.28 & -0.31 & 0.04 \\
\hline 0108010410230031 & 1.16 & -0.63 & 1.79 \\
\hline 0108010410230032 & -0.90 & 0.08 & -0.98 \\
\hline 0108010410230034 & 1.70 & -0.37 & 2.06 \\
\hline 0108010410230035 & 1.16 & -0.45 & 1.61 \\
\hline 0108010410230037 & 1.49 & -0.37 & 1.86 \\
\hline 0108010410230038 & 0.52 & -0.56 & 1.08 \\
\hline 0108010410230039 & -1.19 & 0.27 & -1.46 \\
\hline 0108010410230041 & -0.08 & -0.14 & 0.06 \\
\hline 0108010410230042 & -1.69 & -0.63 & -1.07 \\
\hline 0108010410230045 & -0.91 & 0.10 & -1.01 \\
\hline 0108010410230046 & -0.22 & -0.20 & -0.03 \\
\hline 0108010410230047 & 1.49 & -0.69 & 2.18 \\
\hline 0108010410311 & -2.34 & -0.41 & -1.93 \\
\hline 0108010410315 & 0.28 & -0.55 & 0.83 \\
\hline 0108010410316 & -1.21 & -0.13 & -1.08 \\
\hline 0108010410320 & 0.04 & 0.16 & -0.12 \\
\hline 0108010410325 & -1.19 & 0.00 & -1.20 \\
\hline 0108010410327 & -1.16 & -0.20 & -0.97 \\
\hline 0108010410328 & 1.45 & 0.04 & 1.41 \\
\hline 0108010410333 & -0.87 & -0.85 & -0.02 \\
\hline 0108010410335 & -1.67 & -0.48 & -1.19 \\
\hline 0108010410337 & -1.94 & -0.44 & -1.50 \\
\hline 0108010410339 & -1.79 & -0.25 & -1.54 \\
\hline 0108010410340 & -2.79 & -0.14 & -2.65 \\
\hline 0108010410343 & -1.89 & -0.78 & -1.11 \\
\hline 0108010410344 & -2.67 & -0.57 & -2.10 \\
\hline 0108010410350 & 1.10 & -0.16 & 1.26 \\
\hline 0108010410351 & -0.69 & -0.80 & 0.11 \\
\hline 0108010410357 & -0.66 & -0.41 & -0.26 \\
\hline 0108010410358 & -1.86 & -0.93 & -0.93 \\
\hline 0108010410372 & 0.86 & -0.84 & 1.69 \\
\hline 0108010410373 & 0.84 & -0.66 & 1.50 \\
\hline 0108010410376 & -1.86 & 0.49 & -2.35 \\
\hline 0108010410385 & -1.93 & -0.62 & -1.32 \\
\hline 0108010410388 & 1.17 & -0.57 & 1.74 \\
\hline 0108010410392 & -0.12 & -0.65 & 0.54 \\
\hline 0108010410393 & 0.11 & -0.79 & 0.90 \\
\hline 0108010410400-1 & -0.64 & -1.05 & 0.41 \\
\hline 0108010410405-1 & 1.17 & -0.76 & 1.93 \\
\hline 0108010410407-1 & 0.86 & -0.21 & 1.07 \\
\hline 0108010410414-1 & -0.72 & 0.01 & -0.73 \\
\hline
\end{tabular}


Tabel G.1: Oversigt over forkerte og korrekte itemsværhedsgrader. (continued)

\begin{tabular}{|c|c|c|c|}
\hline Item & Korrekt værdi & Forkert værdi & Forskel i værdi \\
\hline 0108010415102 & -2.24 & -0.52 & -1.72 \\
\hline 0108010415109 & 1.43 & -0.49 & 1.92 \\
\hline 0108010415111 & 0.45 & -0.06 & 0.51 \\
\hline 0108010415113 & 1.33 & 0.54 & 0.78 \\
\hline 0108010415180 & 2.49 & 0.58 & 1.91 \\
\hline 0108010420003 & -0.41 & -0.51 & 0.10 \\
\hline 0108010420041 & -1.73 & 0.07 & -1.80 \\
\hline 0108010420042 & -0.93 & -0.51 & -0.42 \\
\hline 0108010420088 & 1.13 & -0.64 & 1.77 \\
\hline 0108010420129 & 1.51 & 0.16 & 1.36 \\
\hline 0108010420138 & 1.45 & -0.75 & 2.20 \\
\hline 0108010420141 & 0.06 & -1.10 & 1.16 \\
\hline 0108010420152 & 0.88 & -0.49 & 1.36 \\
\hline 0108010420153 & 1.37 & -0.15 & 1.52 \\
\hline 0108010420157 & 1.23 & -0.91 & 2.14 \\
\hline 010803000301238567-1 & 0.48 & 0.48 & 0.00 \\
\hline 010803000301238628-1 & 1.52 & 1.52 & 0.00 \\
\hline 010803000301238640-1 & -0.03 & -1.49 & 1.46 \\
\hline 010803000301238646-1 & -0.51 & -0.76 & 0.25 \\
\hline 010803000301238708-1 & 1.28 & 1.28 & 0.00 \\
\hline 010803000301238728-1 & -0.07 & -0.61 & 0.54 \\
\hline 010803000301238729-1 & -0.28 & 0.53 & -0.81 \\
\hline 010803000301238841-1 & 0.89 & 0.89 & 0.00 \\
\hline 010803000301238844-1 & -0.08 & -1.52 & 1.44 \\
\hline 010803000301238868-1 & 1.45 & 1.45 & 0.00 \\
\hline 010803000301238871-1 & -0.25 & -1.10 & 0.85 \\
\hline 010803000301238874-1 & -0.58 & -0.61 & 0.03 \\
\hline 010803000301238989-1 & 0.22 & 0.22 & 0.00 \\
\hline 010803000301238990-1 & -0.32 & 0.28 & -0.60 \\
\hline 010803000301238992-1 & -0.24 & 0.23 & -0.47 \\
\hline 010803000301239051-1 & -0.26 & -0.88 & 0.61 \\
\hline 010803000301239061-1 & -0.16 & -0.48 & 0.33 \\
\hline 010803000301239062-1 & -0.28 & 0.28 & -0.55 \\
\hline 010803000301239063-1 & 0.36 & -1.96 & 2.32 \\
\hline 010803000301241375-1 & -0.33 & 0.27 & -0.60 \\
\hline 010803000301241378-1 & -0.40 & -1.07 & 0.67 \\
\hline 010803000301241381-1 & -0.41 & -1.69 & 1.28 \\
\hline 010803000301241383-1 & -0.29 & -1.61 & 1.32 \\
\hline 010803000301241391-1 & -0.01 & -0.01 & 0.00 \\
\hline 010803000301241409-1 & -0.25 & -0.58 & 0.33 \\
\hline 010803000301241410-1 & -0.33 & -0.36 & 0.02 \\
\hline 010803000301241412-1 & -0.80 & -0.73 & -0.07 \\
\hline 010803000301241413-1 & -0.22 & -0.84 & 0.62 \\
\hline 010803000301241414-1 & -0.55 & -0.28 & -0.27 \\
\hline 010803000301241415-1 & -0.34 & -1.37 & 1.03 \\
\hline
\end{tabular}


Tabel G.1: Oversigt over forkerte og korrekte itemsværhedsgrader. (continued)

\begin{tabular}{|c|c|c|c|}
\hline Item & Korrekt værdi & Forkert værdi & Forskel i værdi \\
\hline 010803000301241593-1 & -0.46 & -0.97 & 0.51 \\
\hline 010803000301241597-1 & -0.17 & -1.00 & 0.83 \\
\hline 010803000301241806-1 & -0.30 & -1.46 & 1.17 \\
\hline 010803000301241807-1 & -0.17 & -1.52 & 1.34 \\
\hline 010803000301241808-1 & -0.31 & -0.49 & 0.17 \\
\hline 010803000301241811-1 & -0.63 & -0.48 & -0.16 \\
\hline 010803000301241812-1 & 0.08 & -1.84 & 1.92 \\
\hline 010803000301241917-1 & -0.37 & -0.59 & 0.23 \\
\hline 010803000301241921-1 & -0.45 & -0.72 & 0.27 \\
\hline 010803000301241924-1 & -0.37 & -0.60 & 0.23 \\
\hline 010803000301241925-1 & -0.56 & -0.51 & -0.05 \\
\hline 010803000301241926-1 & 0.27 & -1.09 & 1.36 \\
\hline 010803000301242169-1 & -0.14 & -0.63 & 0.49 \\
\hline 010803000301242171-1 & -0.63 & -1.21 & 0.59 \\
\hline 010803000301242180-1 & 0.10 & -0.66 & 0.76 \\
\hline 010803000301242204-1 & -0.20 & -0.84 & 0.65 \\
\hline 010803000301242207-1 & -0.69 & -0.43 & -0.26 \\
\hline 010803000301242228-1 & -0.41 & -0.48 & 0.07 \\
\hline 010803000301242234-1 & -0.55 & -1.37 & 0.83 \\
\hline 010803000301242250-1 & -0.13 & -0.67 & 0.54 \\
\hline 010803000301242254-1 & 0.16 & -0.68 & 0.84 \\
\hline 010803000301242264-1 & 0.00 & -1.10 & 1.10 \\
\hline 010803000301242269-1 & -0.20 & -0.80 & 0.60 \\
\hline 010803000301242272-1 & 0.04 & -0.34 & 0.38 \\
\hline 010803000301242274-1 & -0.85 & -0.82 & -0.04 \\
\hline 010803000301242310-1 & -0.48 & -0.12 & -0.35 \\
\hline 010803000301242313-1 & -0.44 & -1.08 & 0.64 \\
\hline 010803000301242315-1 & -0.25 & -0.91 & 0.66 \\
\hline 010803000301242596-1 & -0.14 & -1.30 & 1.16 \\
\hline 010803000301242597-1 & -0.78 & -0.49 & -0.29 \\
\hline 010803000301242601-1 & -0.57 & -1.71 & 1.14 \\
\hline 010803000301242603-1 & -0.16 & -1.17 & 1.01 \\
\hline 010803000301242744-1 & -0.80 & -0.75 & -0.04 \\
\hline 010803000301243169-1 & -0.41 & -0.27 & -0.14 \\
\hline 01080303060910323 & -0.44 & -0.44 & 0.00 \\
\hline 01080303060910325 & -0.84 & -0.82 & -0.02 \\
\hline 01080303060910327 & -0.66 & -0.93 & 0.27 \\
\hline 0108030310009-2 & 0.68 & 0.68 & 0.00 \\
\hline 0108030310011-1 & -0.62 & -1.51 & 0.90 \\
\hline 0108030310015-2 & -0.57 & -1.57 & 1.01 \\
\hline 0108030310016-2 & -0.65 & -1.14 & 0.49 \\
\hline 0108030310372 & 0.82 & 0.82 & 0.00 \\
\hline 0108030310609-1 & 1.02 & 1.02 & 0.00 \\
\hline 0108030310612-1 & -0.48 & -0.48 & 0.00 \\
\hline 0108030311028 & -0.99 & -0.99 & 0.00 \\
\hline
\end{tabular}


Tabel G.1: Oversigt over forkerte og korrekte itemsværhedsgrader. (continued)

\begin{tabular}{cccc}
\hline Item & Korrekt værdi & Forkert værdi & Forskel i værdi \\
\hline 0108030311030 & 0.01 & -1.21 & 1.22 \\
0108030320015 & 0.29 & 0.29 & 0.00 \\
0108030320016 & -0.49 & -1.10 & 0.61 \\
$0108030320019-2$ & -0.06 & -0.85 & 0.79 \\
$0108030320053-1$ & 0.84 & 0.84 & 0.00 \\
$0108030320063-1$ & -0.26 & -0.26 & 0.00 \\
$01080306061330063-2$ & -0.39 & -0.39 & 0.00 \\
$01080306061330065-1$ & 0.07 & -1.07 & 1.14 \\
$01080306061340006-1$ & 0.28 & 0.28 & 0.00 \\
$0108030610700-2$ & -0.61 & -0.61 & 0.00 \\
$0108030610705-2$ & -0.43 & -0.43 & 0.00 \\
$0108030612006-1$ & -1.46 & -1.46 & 0.00 \\
$0108030612014-1$ & 0.59 & 0.59 & 0.00 \\
$0108030612014-2$ & -0.49 & -0.81 & 0.32 \\
$0108030612019-2$ & -0.05 & -0.05 & 0.00 \\
\hline
\end{tabular}




\section{Litteratur}

Adams, Raymond J., og Mark Wilson. 1996. "Formulating the Rasch Model as a Mixed Coefficients Multinomial Logit Model". I Objective Measurement: Theory into Practice Volume 3, 143-66. Norwood, NJ: Ablex Publishing.

Adams, Raymond J., og Margaret L. Wu. 2007. "The Mixed-Coefficients Multinomial Logit Model: A Generalized Form of the Rasch Model". I Multivariate and Mixture Distribution Rasch Models, redigeret af Matthias von Davier og Claus H. Carstensen, 57-76. New York: Springer Science Business Media.

Adams, Raymond J., Mark Wilson, og Wen-chung Wang. 1997. "The Multidimensional Random Coefficients Multinomial Logit Model". Applied Psychological Measurement 21 (1): 1-23.

"Aftale Mellem Regeringen (Socialdemokraterne, Radikale Venstre Og Socialistisk Folkeparti), Venstre Og Dansk Folkeparti Om et Fagligt Løft Af Folkeskolen". 2013.

Boch, R.D., og M. Aitken. 1981. "Marginal Maximum Likelihood Estimation of Item Parameters: Application of an EM Algorithm". Psykometrika, nr. 46: 443-59.

Bundsgaard, Jeppe. 2016. "Rapport Om Kompetencetest i Hitte På-Projektet". København: DPU, Aarhus Universitet.

—. 2018a. "Det 21. Århundredes Kompetencer". I Skoleudvikling Med It: Forskning $i$ Tre Demonstrationsskolefors $\varnothing g$ I, redigeret af Jeppe Bundsgaard, Marianne Georgsen, Stefan Graf, og Thomas Illum Hansen, 143-65. Aarhus: Aarhus Universitetsforlag.

- 2018b. "Test Og Måling i Fagene". I Udvikling i Didaktik Didaktik $i$ Udvikling, redigeret af Torben Spanget Christensen, Nikolaj Elf, Peter Hobel, og Ane Qvortrup. Aarhus: Klim.

. 2018c. "Pædagogisk brug af test". Sakprosa 10 (2). doi:10.5617/sakprosa.6007.

Bundsgaard, Jeppe, og Morten Rasmus Puck. 2016. Nationale Test - Danske Larere Og Skolelederes Brug, Holdninger Og Viden. DPU, Aarhus Universitet.

Care, Esther, Claire Scoular, og Patrick Griffin. 2016. "Assessment of Collaborative Problem Solving in Education Environments". Applied Measurement in Education 29 (4): 250-64. doi:10.1080/08957347.2016.1209204.

Feinman, Joshua. 2008. "High Stakes, but Low Validity? A Case Study of Standardized Tests and Admissions 
into New York City Specialized High Schools." Boulder; Tempe: Education and the Public Interest Center \& Education Policy Research Unit.

Geisinger, Kurt F. 2016. "21st Century Skills: What Are They and How Do We Assess Them?" Applied Measurement in Education 29 (4): 245-49. doi:10.1080/08957347.2016.1209207.

Greenstein, Laura M. 2012. Assessing 21st Century Skills: A Guide to Evaluating Mastery and Authentic Learning. Corwin Press.

Griffin, Patrick, og Esther Care, red. 2015. Assessment and Teaching of 21st Century Skills. Dordrecht: Springer Netherlands. doi:10.1007/978-94-017-9395-7.

Hale, Charles Dennis, og Douglas Astolfi. 2014. Measuring Learning and Performance: A Primer. 3rd edition. St. Leo, Florida: Saint Leo University.

Harbo, Ulf. 2015. "Norddjurs kommune udfordrer de Nationale test - Folkeskolen.dk". https://www.folkeskolen.dk/573670/norddjurs-kommune-udfordrer-de-nationale-test.

Hoover, Wesley A., og Philip B. Gough. 1990. "The Simple View of Reading". Reading and writing 2 (2): $127-60$.

Kousholt, Kristine. 2015. "Børns Gætterier Ved Nationale Test”. Cepra-striben, Nationale Tests,, nr. 18: $46-57$.

Kreiner, Svend. 2007. "Den Adaptive Procedure".

Kreiner, Svend, og Karl Bang Christensen. 2013. "Person Parameter Estimation and Measurement in Rasch Models". I Rasch Models in Health, redigeret af Karl Bang Christensen, Svend Kreiner, og M Mesbah, 63-78. London: ISTE \& John Wiley \& Sons.

"Lov Om Ændring Af Lov Om Folkeskolen". 2006.

Norling, Marina. 2016. "De nationale test 2016 - hvor galt står det til? (1) - Folkeskolen.dk". Folkeskolen.dk. https://www.folkeskolen.dk/586828/de-nationale-test-2016 - hvor-galt-staar-det-til-1.

Rasch, G. 1960. Probabilistic Models for Some Intelligence and Attainment Tests. Studies in Mathematical Psychology, Vol. 1. Copenhagen: Danmarks Pædagogiske Institut.

Ravn, Karen. 2014. "Ups de nationale test måler ikke så præcist som lovet - Folkeskolen.dk". Folkeskolen.dk. https://www.folkeskolen.dk/539694/ups-de-nationale-test-maaler-ikke-saa-praecist-som-lovet.

—. 2015a. "Duer ikke: En femtedel af opgaverne i de nationale test kasseret - Folkeskolen.dk". folkeskolen.dk. https://www.folkeskolen.dk/572751/duer-ikke-en-femtedel-af-opgaverne-i-de-nationale-testkasseret.

—. 2015b. "Eksperter dumper de nationale test - Folkeskolen.dk". Folkeskolen.dk. https://www.folkeskolen.dk/572813/eksperter-dumper-de-nationale-test.

_. 2015c. "Skoleleder: Testresultater svinger, som vinden blæser - Folkeskolen.dk". Folkeskolen.dk. https://www.folkeskolen.dk/572808/skoleleder-testresultater-svinger-som-vinden-blaeser.

Riise, Andreas Brøns. 2014. "Nationale test: Klasse havde kæmpe udsving på tre dage - Folkeskolen.dk". https://www.folkeskolen.dk/540229/nationale-test-klasse-havde-kaempe-udsving-paa-tre-dage.

Robitzsch, Alexander, Thomas Kiefer, og Margaret Wu. 2019. TAM: Test Analysis Modules. https://CRAN. R-project.org/package $=$ TAM.

Rosenbaum, Paul R. 1989. "Criterion-Related Construct Validity". Psychometrika 54 (4): 625-33. doi:10.1007/BF02296400.

Siddiq, Fazilat, Perman Gochyyev, og Mark Wilson. 2017. "Learning in Digital Networks Literacy: 
A Novel Assessment of Students' 21st Century Skills". Computers \& Education 109 (juni): 11-37. doi:10.1016/j.compedu.2017.01.014.

Smarter Balanced Assessment Consortium. 2018. "Smarter Balanced Assessment Consortium: 2016-17 Technical Report".

Styrelsen for It og Læring. 2015. "Den adaptive algoritme i De Nationale Test". København: Undervisningsministeriet, Styrelsen for It og Læring.

- 2016a. Test- Og Prøvesystemet - De Nationale Test. Brugervejledning for Skoler. København: Ministeriet for Børn, Unge og Undervisning.

—. 2016b. "Undersøgelse af de nationale tests reliabilitet". København: Undervisningsministeriet.

—_. 2016c. "Nationale Tests Måleegenskaber". København: Undervisningsministeriet.

—. 2017. "Vejledning Til Nye Resultatvisninger i de Nationale Test Til Lærere i Alle Fag". København: Styrelsen for It og Læring.

Styrelsen for Undervisning og Kvalitet. 2016. "Undersøgelse Af Udsving i Testresultater På Ørum Skole i Norddjurs Kommune". Styrelsen for Undervisning og Kvalitet.

Taylor, Wilson L. 1953. "Cloze Procedure: A New Tool for Measuring Readability". Journalism Es Mass Communication Quarterly 30 (4): 415-33.

Undervisningsminister Bertel Haarder (V). 2006. "L 101 Forslag til lov om ændring af lov om folkeskolen. (Styrket evaluering og anvendelse af nationale test som pædagogisk redskab samt obligatoriske prøver m.v.)."

Wandall, Jakob. 2010. "Test, prøver og evaluering i grundskolen”. Powerpoints. København: IND/KU.

Wandall, Jakob, Christine Nørrelund, og Mette Dalgaard Nielsen. 2018. "Elevernes Syn På de Nationale Test". Nordic Metrics.

Wells, Craig S, og James A Wollack. 2003. "An Instructor's Guide to Understanding Test Reliability". Testing \& Evaluation Services. University of Wisconsin.

Wilson, Mark. 2003. "On Choosing a Model for Measuring". Methods of Psychological Research-Online 8 (3): $1-22$.

2005. Constructing Measures : An Item Response Modeling Approach. Mahwah, N.J.: Lawrence Erlbaum Associates.

Wright, Benjamin D., og Mark H. Stone. 1979. Best Test Design. Chicago: MESA Press.

Wu, Margaret, Raymond J. Adams, Mark Wilson, og S. Haldane. 2007. ConQuest: Generalised Item Response Modelling Software (Version 2.0). Camberwell, Australia: ACER Press.

Zwinderman, A. H. 1995. "Pairwise Parameter Estimation in Rasch Models". Applied Psychological Measurement, nr. 19: 369-75. 